\title{
Mountain Island Lake, North Carolina: Analysis of Ambient Conditions and Simulation of Hydrodynamics, Constituent Transport, and Water-Quality Characteristics, 1996-97
}

By Jerad D. Bales, Kathleen M. Sarver, and Mary J. Giorgino

U.S. GEOLOGICAL SURVEY

Water-Resources Investigations Report 01-4138

Prepared in cooperation with Charlotte-Mecklenburg Utilities

Raleigh, North Carolina 2001

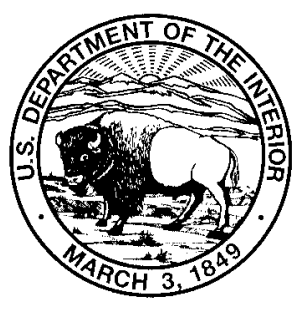




\section{U.S. DEPARTMENT OF THE INTERIOR \\ GALE A. NORTON, Secretary}

U.S. GEOLOGICAL SURVEY

Charles G. Groat, Director

The use of firm, trade, and brand names in this report is for identification purposes

only and does not constitute endorsement by the U.S. Geological Survey.

For additional information write to:

District Chief

U.S. Geological Survey

3916 Sunset Ridge Road

Raleigh, NC 27607

Email:dc_nc@usgs.gov
Copies of this report can be purchased from:

U.S. Geological Survey

Branch of Information Services

Box 25286, Federal Center

Denver, CO 80225

1-888-ASK-USGS 


\section{CONTENTS}

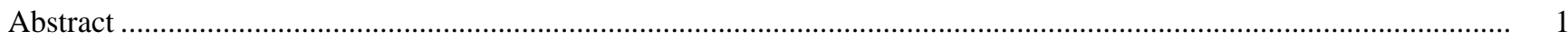

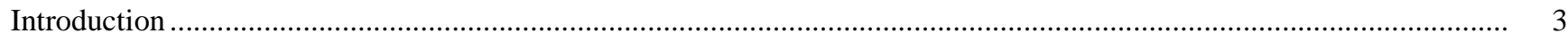

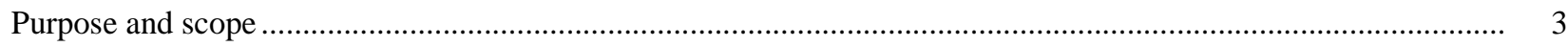

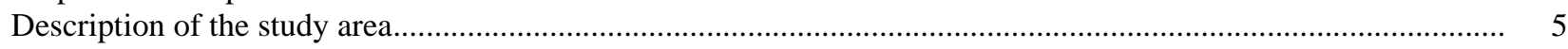

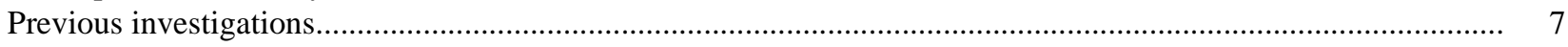

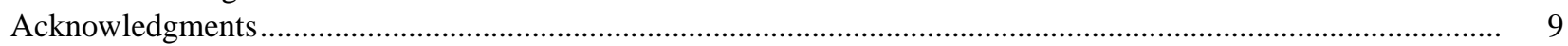

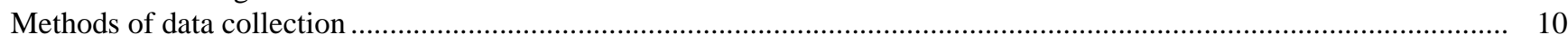

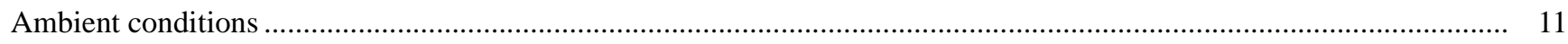

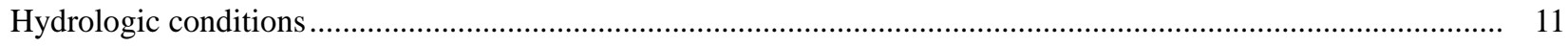

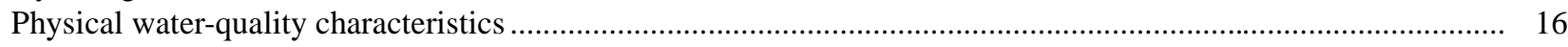

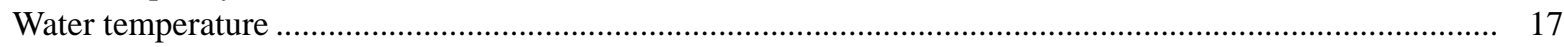

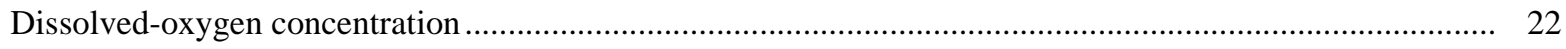

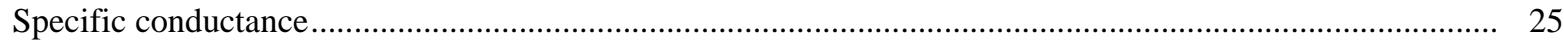

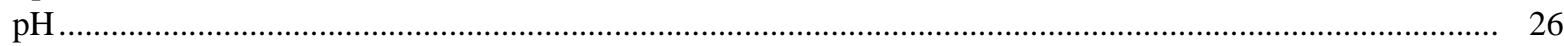

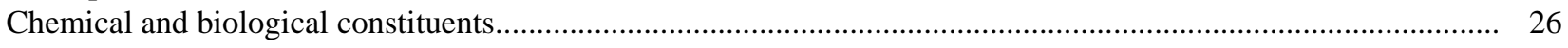

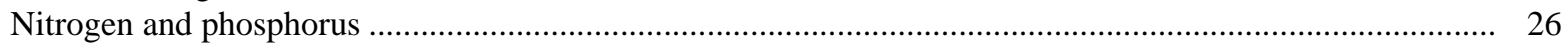

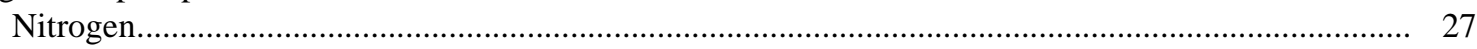

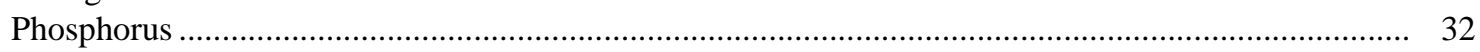

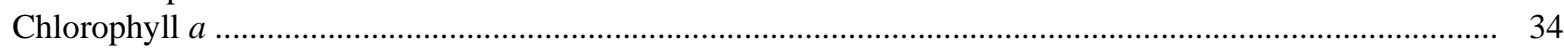

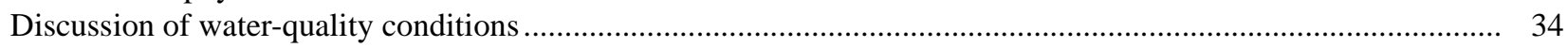

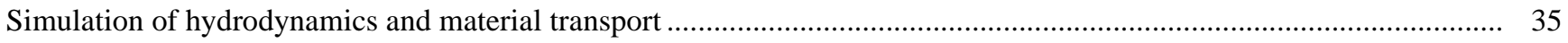

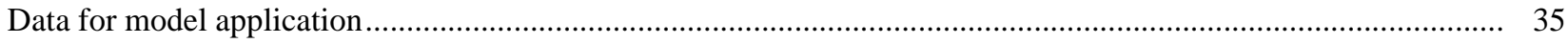

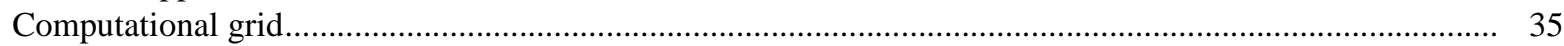

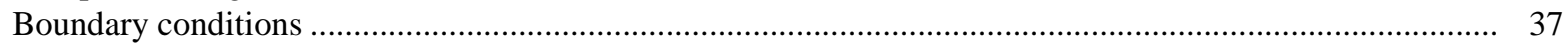

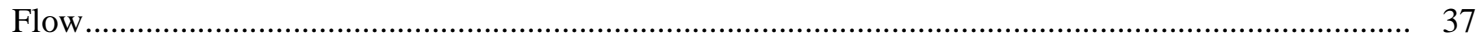

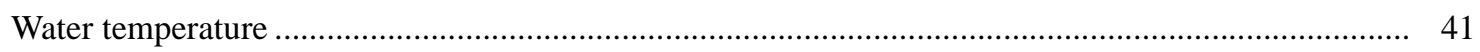

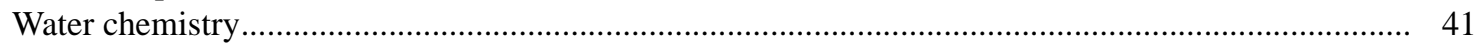

Loads of selected constituents to Mountain Island Lake ............................................................

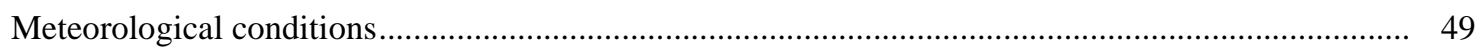

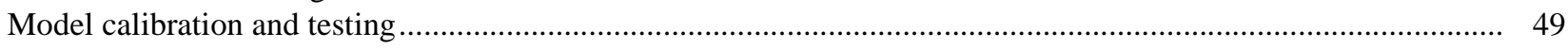

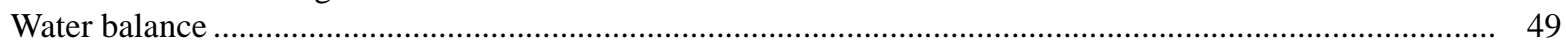

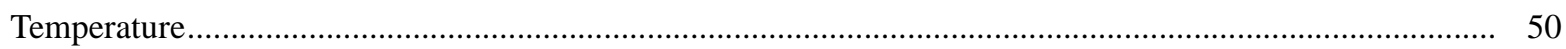

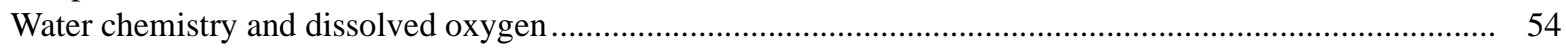

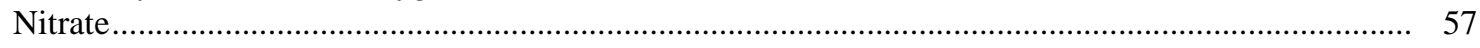

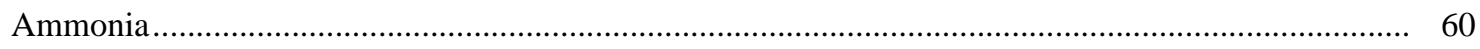

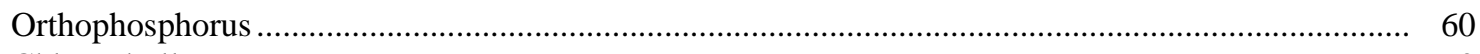

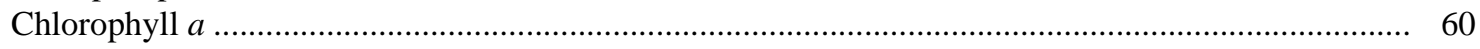

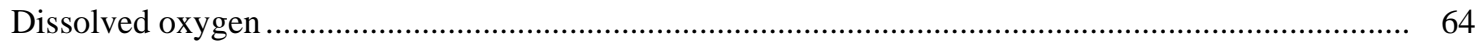

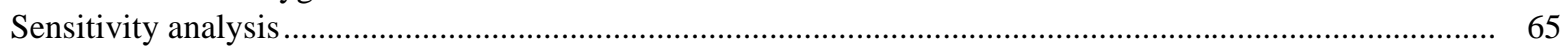

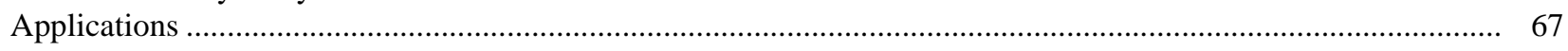

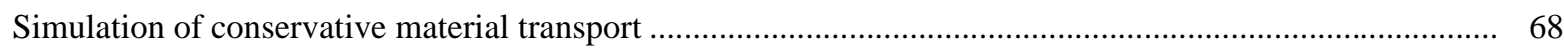

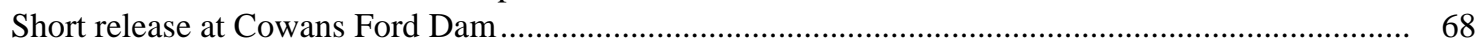

Continuous release into McDowell Creek ................................................................................ 72

Continuous release from the McDowell Creek Wastewater-Treatment Plant...................................... 72

Release during McDowell Creek high-flow event..................................................................

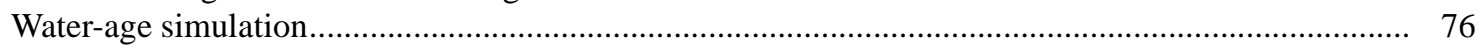

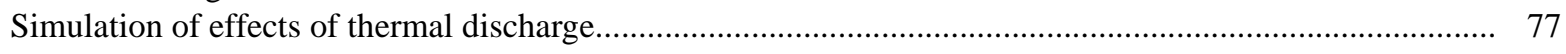

Simulation of effects of increased water-supply withdrawals......................................................... 77

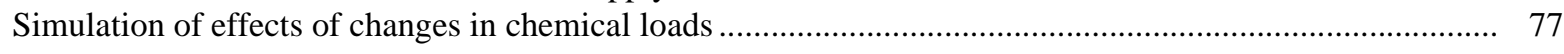

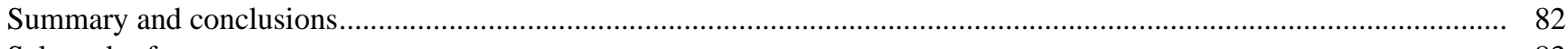

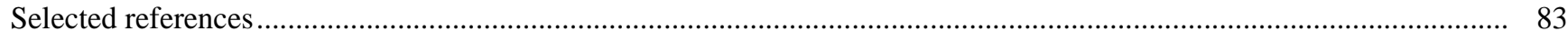




\section{FIGURES}

1-2. Maps showing:

1. The Catawba River Basin, North Carolina and South Carolina

2. Mountain Island Lake, local drainage area, and data-collection sites

3-7. Graphs showing:

3. Monthly precipitation from April 1996 to September 1997 near Mountain Island Lake and 1960-90 at Charlotte/Douglas International Airport.

4. Discharge durations for the Catawba River at Cowans Ford Dam and Catawba River at Mountain Island Dam, September 1, 1996-August 31, 1997.

5. Percentage of time Cowans Ford Dam and Mountain Island Dam were closed, April 1996-September 1997.

6. Selected percentiles of discharge from Cowans Ford Dam and Mountain Island Dam, April 1996-September 1997.

7. Discharge from Cowans Ford Dam and water level at sites 01 and 14,

December 18-31, 1996, and June 10-23, 1997.

8. Diagram of Mountain Island Lake mainstem data-collection points for vertical profile water-quality data.

9-10. Graphs showing:

9. Water temperature durations for Mountain Island Lake continuous water-quality monitoring sites, September 1, 1996-August 31, 1997

10. Discharge from Cowans Ford Dam and water level, water temperature, and dissolved-oxygen concentration at site 01, July 15-19, 1997

11. Diagrams showing distribution of water temperature in Mountain Island Lake for selected days during the study period

12. Graph showing dissolved-oxygen concentration durations for Mountain Island Lake continuous water-quality monitoring sites, September 1, 1996-August 31, 1997.

13. Diagrams showing distribution of dissolved-oxygen concentrations in Mountain Island Lake for selected days during the study period

14-15. Box plots showing:

14. Distribution of specific conductance at Mountain Island Lake continuous water-quality monitoring sites, September 1, 1996-August 31, 1997

15. Distributions of concentrations of (A) nitrite plus nitrate, $(\mathrm{B})$ ammonia, and $(\mathrm{C})$ total ammonia plus organic nitrogen at Mountain Island Lake sites, May 1996-September 1997 .....

16. Graph showing concentrations of nitrite plus nitrate in surface samples collected from Mountain Island Lake sites 01, 09, 13, and 17, May 1996-September 1997

17. Box plots showing distributions of concentrations of (A) orthophosphorus and (B) total phosphorus at Mountain Island Lake sites, May 1996-September 1997.

18. Plan view of the top layer of computational grid for Mountain Island Lake water-quality model.

19. Elevation view of computational layers at model segment 37 for Mountain Island Lake water-quality model

20-21. Hydrographs showing:

20. Comparison of streamflow at the mouth of McDowell Creek (drainage area $=75.9$ square kilometers) estimated from measured streamflow at site 34 (drainage area $=6.10$ square kilometers) and site 44 (drainage area $=68.1$ square kilometers).

21. Daily mean withdrawals from Mountain Island Lake by the Riverbend Steam Station, April 1996-September 1997; releases by the steam station to the lake were equivalent to withdrawals

22-24. Graphs showing:

22. Water temperature measured in McDowell Creek at sites 34 and 44 during May 16-July 30, 1997

23. Concentrations of nitrate, ammonia, and orthophosphorus at site 01 directly downstream from Cowans Ford Dam, May 28, 1996-September 9, 1997. 
24. Daily export of (A) total phosphorus and (B) total nitrogen from McDowell Creek, Cowans Ford Dam, Gar Creek, and McDowell Creek Wastewater-Treatment Plant to Mountain Island Lake for April 2, 1996-September 29, 1997.

25. Hydrograph showing measured and simulated water level at Mountain Island Lake site 14,

December 3, 1996-January 3, 1997

26-45. Graphs showing:

26. Measured and simulated (A) near-surface and (B) near-bottom water temperature at Mountain Island Lake site 14, April 1996-September 1997

27. Measured and simulated vertical distributions of water temperature at three mainstem locations in Mountain Island Lake for six sets of measurements between May 1996 and May 1997

28. Measured and simulated near-surface nitrate concentrations at (A) McDowell Creek cove (site 07), (B) Mountain Island Lake between McDowell Creek and Gar Creek (site 09), (C) Gar Creek cove (site 11), and (D) Mountain Island Lake at N.C. Highway 16 (site 14) for April 1996-October 1997.

29. Simulated nitrate concentrations in Mountain Island Lake for (A) midnight on June 20, 1996, (B) noon on June 20,1996, and (C) midnight on June 21, 1996, demonstrating the effects of stormflow in McDowell Creek on nitrate concentrations in Mountain Island Lake .

30. Measured and simulated near-surface ammonia concentrations at (A) McDowell Creek cove (site 07), (B) Mountain Island Lake between McDowell Creek and Gar Creek (site 09); (C) Gar Creek cove (site 11), and (D) Mountain Island Lake at N.C. Highway 16 (site 14) for April 1996-October 1997

31. Measured and simulated near-surface orthophosphorus concentrations at (A) McDowell Creek cove (site 07), (B) Mountain Island Lake between McDowell Creek and Gar Creek (site 09), (C) Gar Creek cove (site 11), and (D) Mountain Island Lake at N.C. Highway 16 (site 14) for April 1996-October 1997

32. Measured and simulated near-surface chlorophyll $a$ concentrations at (A) McDowell Creek cove (site 07), (B) Mountain Island Lake between McDowell Creek and Gar Creek (site 09), (C) Gar Creek cove (site 11), and (D) Mountain Island Lake at N.C. Highway 16 (site 14) for April 1996-October 1997.

33. Measured and simulated (A) near-surface and (B) near-bottom dissolved-oxygen concentrations in Mountain Island Lake at N.C. Highway 16 (site 14) for May 1996-October 1997.

34. Measured and simulated vertical distributions of dissolved-oxygen concentration at three mainstem locations in Mountain Island Lake for six sets of measurements between May 1996 and May 1997.

35. (A) simulated near-surface and near-bottom concentrations of a conservative, neutrally buoyant material following a 2-hour release of the tracer at model segment 29 , near the Charlotte-Mecklenburg Utilities water intake and Cowans Ford Dam for June 1996 and December 1996 conditions and (B) discharge at Cowans Ford Dam during the simulation period.

36. Simulated longitudinal and vertical distributions of a conservative, neutrally buoyant material following a 2-hour release of the tracer near Cowans Ford Dam at noon on June 17, 1996, for (A) midnight on June 18, (B) noon on June 18, and (C) noon on June 20, 1996

37. Simulated vertical distributions of a conservative, neutrally buoyant material following a 2-hour release of the tracer near Cowans Ford Dam for June 1996 conditions near the water intakes for (A) Charlotte-Mecklenburg Utilities and (B) Gastonia and Mount Holly, and for December 1996 conditions near the water intakes for (C) Charlotte-Mecklenburg Utilities and

(D) Gastonia and Mount Holly

38. (A) Estimated daily mean discharge at the mouth of McDowell Creek, June 18-December 31, 1996; (B) simulated near-surface and near-bottom conservative tracer concentrations near the mouth of McDowell Creek cove (model segment 42); and (C) simulated near-surface and near-bottom conservative tracer concentrations near the water intakes for Charlotte-Mecklenburg Utilities (segment 29) and Gastonia and Mount Holly (segment 37) for a continuous tracer release into McDowell Creek 
39. (A) Simulated near-surface and near-bottom conservative tracer concentrations near the mouth of McDowell Creek cove (model segment 42); and (B) near-bottom conservative tracer concentrations near the water intakes for Charlotte-Mecklenburg Utilities (segment 29) and Gastonia and Mount Holly (segment 37) for a continuous tracer release from the

McDowell Creek Wastewater-Treatment Plant during June 18-December 31, 1996.

40. Simulated near-bottom conservative tracer concentrations near the mouth of McDowell Creek cove (model segment 42), and near water intakes for Mountain Island Dam and Gastonia and Mount Holly (segment 37) for a 2-day continuous tracer release into McDowell Creek during the July 22-23, 1997, storm

41. Simulated Mountain Island Lake water age for (A) July 26, 1996, and (B) February 20, 1997.

42. Simulated (A) near-surface and (B) near-bottom water temperature at site 14 (near the Riverbend Steam Station thermal discharge), and (C) near-surface water temperature at Mountain Island Dam

43. Simulated chlorophyll $a$ concentrations for 1996-97 conditions, a 20-percent increase in concentrations of selected constituents in Cowans Ford releases, and a 20-percent increase in concentrations of selected constituents in McDowell Creek inflows for (A) McDowell Creek cove and (B) Mountain Island Lake site 14

44. Simulated near-bottom dissolved-oxygen concentrations for 1996-97 conditions, a 20-percent increase in concentrations of selected constituents in Cowans Ford releases, and a 20-percent increase in concentrations of selected constituents in McDowell Creek inflows for Mountain Island Lake site 14

45. Simulated suspended solids concentrations in Mountain Island Lake for (A) midnight on July 27, 1996; (B) noon on July 27, 1996; (C) noon on July 28, 1996; and simulated dissolved-oxygen concentrations for (D) noon on July 27, 1996; (E) noon on July 28, 1996; and (F) midnight on August 1, 1996

\section{TABLES}

1. Annual average load of selected constituents in streams at two sites on McDowell Creek (sites 34 and 44) and one site on Gar Creek (site 33), 1994-97, and McDowell Creek Wastewater-Treatment Plant, 1996-97 .......

2. Data-collection network for the Mountain Island Lake study.

3. Estimated water balance for Mountain Island Lake, October 1996-September 1997

4. Riverbend Steam Station cooling water discharge and water temperature data for dates on which vertical profiles of water temperature were measured in Mountain Island Lake.

5. General relation of lake productivity to average concentrations of inorganic nitrogen and total phosphorus.

Statistical summary of selected water-quality properties and constituents at Mountain Island Lake cove sites 07, 11, and 13, May 1996-September 1997.

7. Statistical summary of selected water-quality properties and constituents at Mountain Island Lake riverine sites 01 and 17, May 1996-September 1997.

8. Statistical summary of selected water-quality properties and constituents at Mountain Island Lake mainstem sites 04, 09, and 14, May 1996-September 1997.

9. Range of values for selected inflow and outflow boundary conditions for Mountain Island Lake water-quality model .

10. Comparison of selected constituent concentrations measured nearly simultaneously at two locations on McDowell Creek during low-flow and stormflow conditions

11. Loads of total suspended solids, biochemical oxygen demand, nitrate, ammonia, total nitrogen, and total phosphorus to Mountain Island Lake during May 1, 1996-April 30, 1997.

12. Secchi depths in Mountain Island Lake, Rhodhiss Lake, and Lake Hickory

13. Loads of total suspended solids, biochemical oxygen demand, total nitrogen, and total phosphorus to Mountain Island Lake from McDowell Creek Wastewater-Treatment Plant during May 1, 1996-April 30, 1997, and May 1, 1999-April 30, 2000 
14. Hydraulic and thermal parameters in the calibrated Mountain Island Lake water-quality model.

15. Comparison of measured and simulated water temperature for selected Mountain Island Lake sites

16. Rate coefficients used in water-chemistry simulations for Mountain Island Lake.

17. Comparison of measured and simulated dissolved-oxygen concentrations for selected Mountain

CONVERSION FACTORS, TEMPERATURE, VERTICAL DATUM, DEFINITIONS, and ABBREVIATIONS/ACRONYMS

\begin{tabular}{rcl}
\hline Multiply & By & To obtain \\
\hline & Length & \\
centimeter $(\mathrm{cm})$ & 0.394 & inch \\
meter $(\mathrm{m})$ & 3.281 & foot \\
kilometer $(\mathrm{km})$ & 0.6214 & mile \\
& Area & \\
square meter $\left(\mathrm{m}^{2}\right)$ & 10.76 & square foot \\
square kilometer $\left(\mathrm{km}^{2}\right)$ & 0.3861 & square mile \\
& Volume & \\
liter $(\mathrm{L})$ & 0.2642 & gallon \\
cubic meter $\left(\mathrm{m}^{3}\right)$ & 35.31 & cubic foot \\
& 264.2 & gallon \\
cubic meter $\left(\mathrm{m}^{3}\right)$ & Flow rate & \\
cubic meter per second per & 35.31 & cubic foot per second \\
square kilometer $\left[\left(\mathrm{m}^{3} / \mathrm{s}\right) / \mathrm{km}^{2}\right]$ & 91.49 & cubic foot per second \\
cubic meter per day $\left(\mathrm{m}^{3} / \mathrm{d}\right)$ & 264.2 & per square mile \\
& Mass & gallon per day \\
gram $(\mathrm{g})$ & 0.03527 & ounce, avoirdupois \\
kilogram $(\mathrm{kg})$ & 2.205 & pound, avoirdupois \\
\hline
\end{tabular}

Temperature: Temperature in degrees Celsius $\left({ }^{\circ} \mathrm{C}\right)$ may be converted to degrees Fahrenheit $\left({ }^{\circ} \mathrm{F}\right)$ as follows:

$$
{ }^{\circ} \mathrm{F}=\left(1.8 \mathrm{x}^{\circ} \mathrm{C}\right)+32
$$

Sea level: In this report, "sea level" refers to the National Geodetic Vertical Datum of 1929 (NGVD of 1929) - a geodetic datum derived from a general adjustment of the first-order level nets of the United States and Canada, formerly called Sea Level Datum of 1929.

Specific conductance is given in microsiemens per centimeter $(\mu \mathrm{S} / \mathrm{cm})$ at 25 degrees Celsius.

Water year: The period October 1 through September 30 and identified by the year in which it ends. 

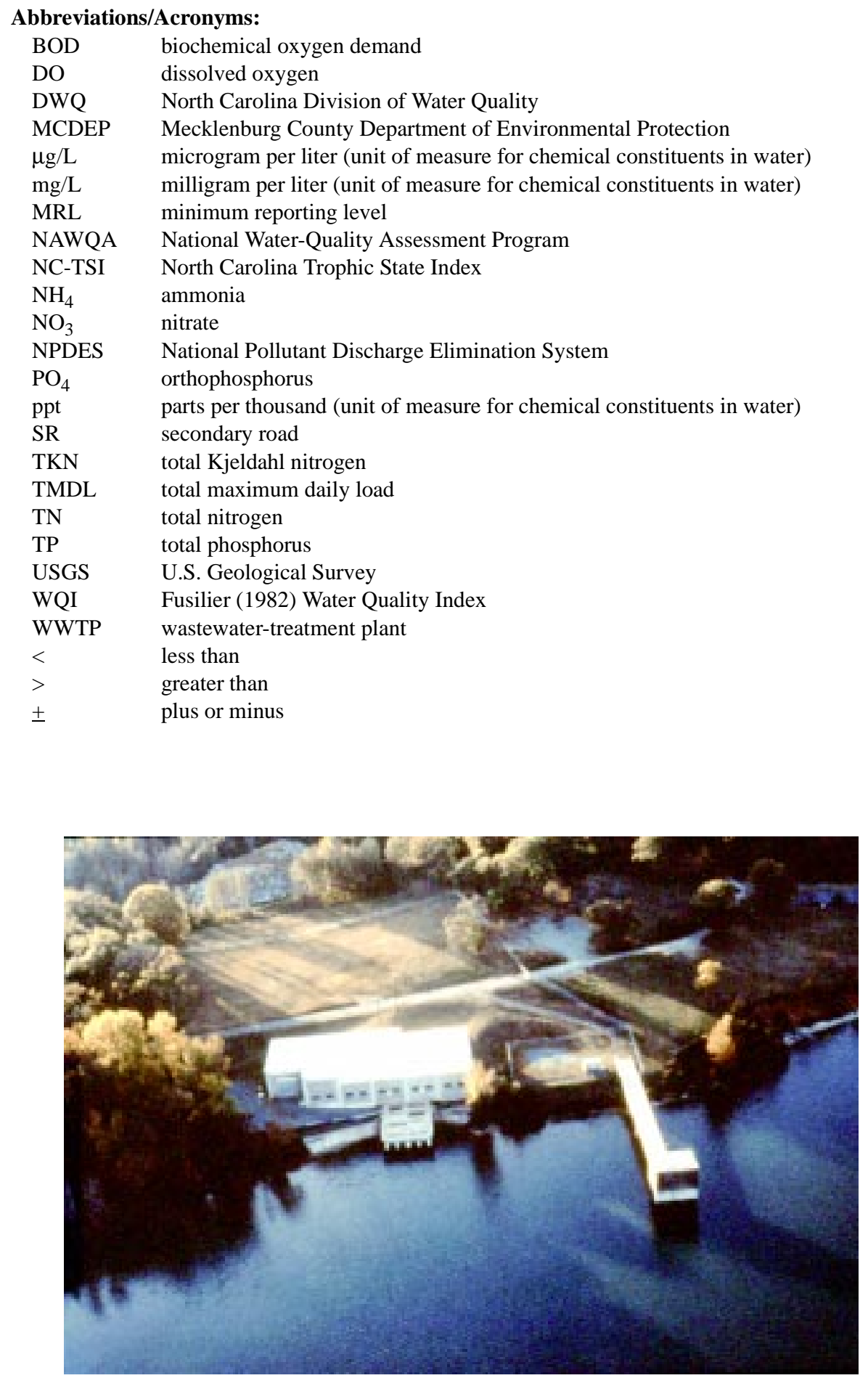

Mount Holly water-supply intake, near Mountain Island Dam (courtesy of Mecklenburg County Department of Environmental Protection) 


\title{
Mountain Island Lake, North Carolina: Analysis of Ambient Conditions and Simulation of Hydrodynamics, Constituent Transport, and Water-Quality Characteristics, 1996-97
}

\author{
By Jerad D. Bales, Kathleen M. Sarver, and Mary J. Giorgino
}

\section{ABSTRACT}

Mountain Island Lake is an impoundment of the Catawba River in North Carolina and supplies drinking water to more than 600,000 people in Charlotte, Gastonia, Mount Holly, and several other communities. The U.S. Geological Survey, in cooperation with the Charlotte-Mecklenburg Utilities, conducted an investigation of the reservoir to characterize hydrologic and waterquality conditions and to develop and apply a simulation model to predict the response of the reservoir to changes in constituent loadings or the flow regime.

During 1996-97, flows into Mountain Island Lake were dominated by releases from Cowans Ford Dam on Lake Norman, with more than 85 percent of the total inflow to the reservoir coming from Lake Norman. Riverbend Steam Station discharges accounted for about 12 percent of the inflows to the reservoir, and inflows from tributary streams contributed less than 1.5 percent of the total inflows. Releases through Mountain Island Dam accounted for about 81 percent of outflows from the reservoir, while Riverbend Steam Station withdrawals, which were equal to discharge from the facility, constituted about 13 percent of the reservoir withdrawals. About 5.5 percent of the withdrawals from the reservoir were for water supply.

Strong thermal stratification was seldom observed in Mountain Island Lake during April 1996-September 1997. As a result, dissolved-oxygen concentrations were only infrequently less than 4 milligrams per liter, and seldom less than 5 milligrams per liter throughout the entire reservoir, including the coves. The Riverbend Steam Station thermal discharge had a pronounced effect on surface-water temperatures near the outfall.

McDowell Creek, which drains to McDowell Creek cove, receives treated wastewater from a large municipal facility and has exhibited signs of poor water-quality conditions in the past. During April 1996-September 1997, concentrations of nitrate, ammonia, total phosphorus, and chlorophyll $a$ were higher in McDowell Creek cove than elsewhere throughout the reservoir. Nevertheless, the highest chlorophyll $a$ concentration measured during the study was 13 micrograms per liter-well below the North Carolina ambient water-quality standard of 40 micrograms per liter. In the mainstem of the reservoir, near-bottom ammonia concentrations occasionally were greater than near-surface concentrations. However, the relatively large topto-bottom differences in ammonia and phosphorus that have been observed in other Catawba River reservoirs were not present in Mountain Island Lake.

External loadings of suspended solids, nitrogen, phosphorus, and biochemical oxygen demand were determined for May 1996-April 1997. Flows through Cowans Ford Dam contributed more than 80 percent of the biochemical oxygen demand and nitrogen load to the reservoir, with McDowell Creek contributing about 15 percent of the biochemical oxygen 
demand load. In contrast, McDowell Creek contributed about half of the phosphorus load to the reservoir, while inflows through Cowans Ford Dam contributed about one-fourth of the phosphorus load, and the McDowell Creek wastewater-treatment plant contributed about 15 percent of the total phosphorus load. The remainder of the phosphorus loadings came from Gar Creek and the discharge from the Riverbend ash settling pond.

Mountain Island Lake is a relatively small (11.3-square-kilometer surface area) impoundment. An area of 181 square kilometers drains directly to the reservoir, but much of this area is undergoing development. In addition, the reservoir receives treated effluent from a municipal wastewater-treatment facility.

The two-dimensional, laterally averaged model CE-QUAL-W2 was applied to Mountain Island Lake. The model was configured to simulate water level, water temperature, and 12 water-quality constituents. The model included the mainstem, four coves, three point-source discharges, and three withdrawals.

Simulated water levels generally were within 10 centimeters of measured values, indicating a good calibration of the water balance for the reservoir. The root-mean-square difference between measured and simulated water temperatures was about 1 to 1.5 degrees Celsius, and vertical distributions of water temperature were accurately simulated in both the mainstem and coves.

Seasonal and spatial patterns of nitrate, ammonia, orthophosphorus, and chlorophyll $a$ were reasonably reproduced by the water-quality model. Because of the absence of the denitrification process in the model formulation, nitrate concentrations typically were overpredicted. Simulated and measured ammonia concentrations seldom differed by more than 0.01 milligram per liter, and simulations of seasonal fluctuations in chlorophyll $a$ were representative of measured conditions. The root mean square of the difference between measured and simulated dissolved-oxygen concentrations was about 1 milligram per liter.
The calibrated water-quality model was applied to evaluate (1) the movement of a conservative, neutrally buoyant material, or tracer, through the reservoir for several sets of conditions; (2) the effects of the Riverbend thermal discharge on water temperature in the reservoir; (3) the effects of changes in water-supply withdrawal rates on water-quality conditions; and (4) changes in reservoir water quality in response to changes in point- and nonpoint-source loadings. In general, dissolved material entering Mountain Island Lake from both Cowans Ford Dam and McDowell Creek during the summer moves along the bottom of the lake toward Mountain Island Dam, with little mixing of dissolved material into the surface layers. Simulations suggest that dissolved material can move upstream in the reservoir when flows from Cowans Ford Dam are near zero. Dissolved material can remain in Mountain Island Lake for a period far in excess of the theoretical retention time of 12 days.

Simulations indicated that the Riverbend thermal discharge increases water temperature in the surface layers of the downstream part of the reservoir by as much as 5 degrees Celsius. However, the discharge has little effect on nearbottom water temperature.

Based on model simulations, a proposed doubling of the water-supply withdrawals from Mountain Island Lake has no readily apparent effect on water quality in the reservoir. The increased withdrawal rate may have some localized effects on circulation in the reservoir, but a more detailed model of the intake zone would be required to identify those effects.

The effects of a 20-percent increase in water-chemistry loadings through Cowans Ford Dam and from McDowell Creek were simulated separately. Increased loadings from Cowans Ford Dam had about the same effect on water-quality conditions near Mountain Island Dam as did increased loadings from McDowell Creek. Maintaining good water quality in Mountain Island Lake depends on maintaining good water quality in Lake Norman as well as in the inflows from the McDowell Creek watershed. 


\section{INTRODUCTION}

Mountain Island Lake, an impoundment of the Catawba River (fig. 1), was constructed in 1923 to supply hydroelectric power for a growing population and textile industry near Charlotte, North Carolina. In addition to power generation, the reservoir supplies water for drinking and industrial use, industrial processing, irrigation, waste assimilation, recreation, and fish and wildlife habitats.

Information regarding circulation and constituent transport in Mountain Island Lake is needed to more effectively manage this important water-supply reservoir and its watershed and to predict water-quality responses to changes in constituent loading or the flow regime. Such changes may result from State watershed-protection regulations, changes in wastewater-treatment plant practices in the Mountain Island Lake watershed, changes in watersupply withdrawals from the lake, and the basinwide approach used by State regulators to permit pointsource discharges. Loads of nonpoint-source pollutants could change as a result of continued administration of sedimentation-control management practices or increasing urban development.

The U.S. Geological Survey (USGS), in cooperation with Charlotte-Mecklenburg Utilities, conducted an investigation of Mountain Island Lake to characterize hydrologic and water-quality conditions within the reservoir and to develop tools to simulate the effects of changes in external conditions on reservoir water quality. Water levels, streamflow, and water quality were monitored during 1996-97 (Sarver and Steiner, 1998), and circulation and water-quality processes in Mountain Island Lake were simulated by using the U.S. Army Corps of Engineers' CE-QUAL-W2 model.

In addition to the Mountain Island Lake study, the USGS has conducted several other water-quality investigations in the Catawba River Basin. During 1993-94, the USGS, in cooperation with the Western Piedmont Council of Governments, conducted an investigation of water quality in the upper Catawba River Basin, primarily in Rhodhiss Lake and Lake Hickory (Jaynes, 1994; Giorgino and Bales, 1997; Bales and Giorgino, 1998). Water-quality and waterlevel data from streams and reservoirs were collected and interpreted. An unsteady water-quality transport model was developed and applied to each reservoir to simulate circulation and water-quality processes, and to simulate the effects of changes in chemical loadings on reservoir water quality.

In cooperation with the City of Charlotte and Mecklenburg County, the USGS collected and interpreted hydrologic data for the city and county from several small urban basins located within the Catawba River Basin during 1993-98. Study efforts focused on characterizing urban stormwater quantity and quality from selected land uses and providing information on nonpoint-source loadings of selected constituents to the Catawba River (Robinson, Hazell, and Garrett, 1996, 1998; Bales and others, 1999; Sarver and others, 1999).

An unsteady flow and water-quality transport model of the Catawba River between Wylie Dam and the headwaters of Fishing Creek Reservoir in South Carolina is under development as part of a study conducted in cooperation with Lancaster County Water and Sewer Authority (N. Hurley, U.S. Geological Survey, oral commun., November 2000). The Catawba River Basin also is part of the USGS National WaterQuality Assessment (NAWQA) Program's Santee River Basin Study Unit. Data were collected synoptically and at fixed sites in the Catawba River Basin as part of the NAWQA study, which began in 1994 (Hughes, 1994; Maluk and Kelley, 1997; Maluk and others, 1998). Together, these studies are using consistent, high-quality data-collection techniques to provide data that are being used to develop predictive tools and management information for the Catawba River Basin.

\section{Purpose and Scope}

The purpose of this report is to (1) characterize ambient hydrologic and water-quality conditions in Mountain Island Lake and the coves of two main tributaries (Gar Creek and McDowell Creek), (2) document calibration of the CE-QUAL-W2 model for Mountain Island Lake, and (3) present results of model simulations for selected scenarios. As outlined in the USGS and Water-Resources Division strategic plans, the USGS has a commitment to conduct scientific investigations that provide for better protection of water supplies and develop simulation models that are capable of predicting the responses of natural systems to external changes.

The study area includes the Mountain Island Lake watershed from Cowans Ford Dam to Mountain Island Dam. Data collected during the period April 1996-September 1997 were used to characterize 


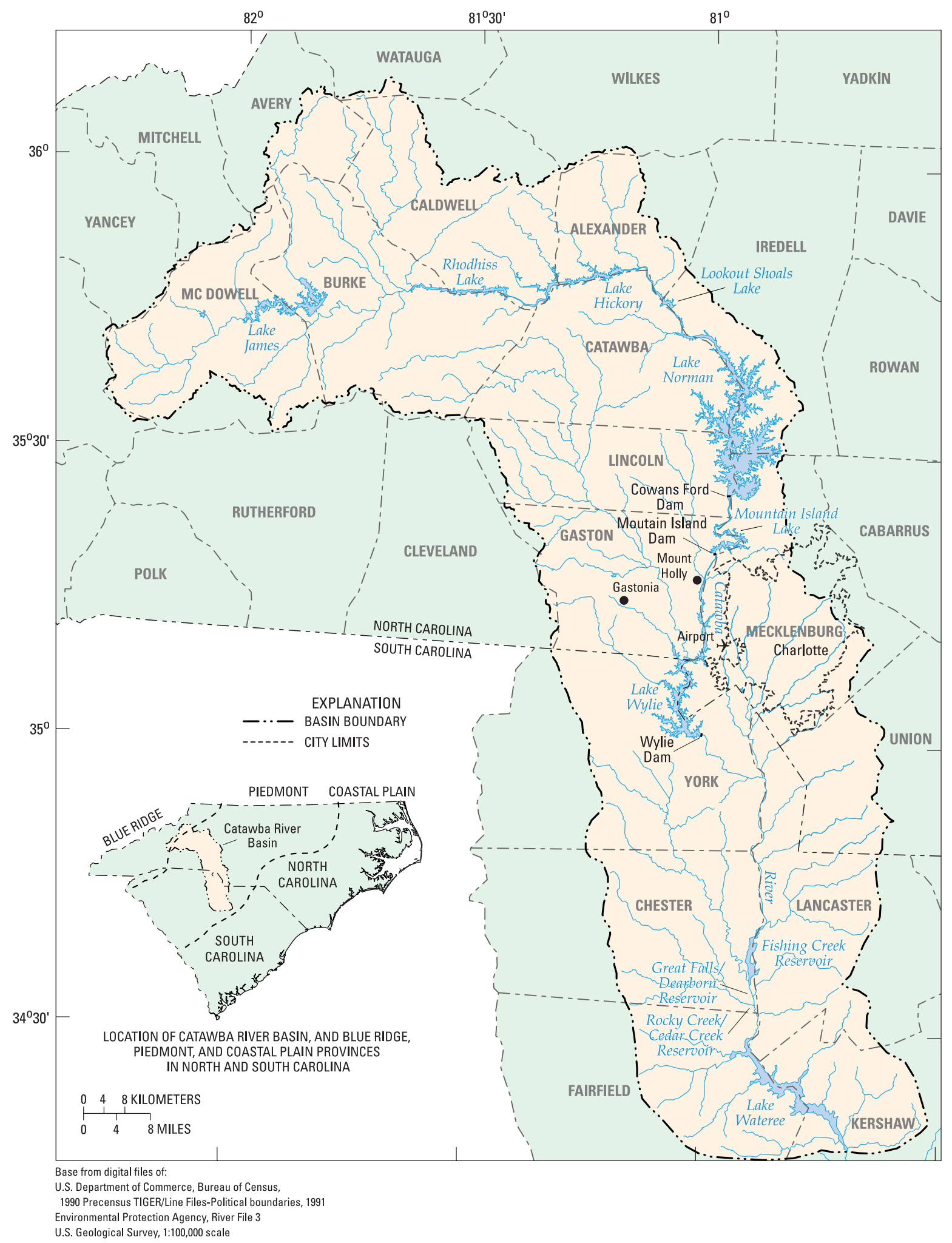

Figure 1. The Catawba River Basin, North Carolina and South Carolina. 
ambient conditions and to develop and apply the waterquality model. Although data were collected for more than a year, much of the data analysis focused on the 12-month period September 1996-August 1997 when the most complete data set was available. Hydrologic and water-quality data that were collected from Mountain Island Lake during the entire study period were published previously (Sarver and Steiner, 1998).

Hydrologic data include water-level measurements in the reservoir and dam-release records from Cowans Ford Dam and Mountain Island Dam. Physical water-quality characteristics include water temperature, dissolved-oxygen (DO) concentration, specific conductance, and $\mathrm{pH}$ measured at 15 sites located in the mainstem and several coves of Mountain Island Lake and 1 site on the Catawba River downstream from Mountain Island Dam. In addition, concentrations of a suite of chemical constituents were determined from samples collected at eight sites. These data, as well as meteorological data, were used to calibrate and apply the water-quality model.

Results are summarized for physical waterquality characteristics and selected chemical and biological constituents, including nitrogen and phosphorus species and chlorophyll $a$. Temporal and spatial patterns of water quality in Mountain Island Lake are described and, when appropriate, conditions are compared to prevailing water-quality standards and to conditions observed in similar systems. The hydrologic and water-quality data from Gar and McDowell Creeks used in the water-quality model for Mountain Island Lake were published previously (Robinson, Hazell, and Garrett, 1998; Bales and others, 1999) and are not presented in this report.

Hydraulic circulation and water-quality characteristics in Mountain Island Lake were simulated by using a two-dimensional, laterally averaged, unsteady flow and transport model. This model was calibrated to simulate physical and water-quality conditions along the length and throughout the full depth of the reservoir by using data collected from April 1996 to September 1997. The calibrated model was applied to evaluate (1) the movement of a conservative tracer through the reservoir for several sets of conditions, (2) the effects of the Riverbend Steam Station thermal discharge on water temperatures in the reservoir, (3) the effects of changes in waterwithdrawal rates on water-quality conditions in the reservoir, and (4) changes in reservoir water quality in response to changes in point- and nonpoint-source loadings.

\section{Description of the Study Area}

The Catawba River in North Carolina extends from the mountains of the Blue Ridge Province to Lake Wylie, which lies along the North Carolina-South Carolina State line in the Piedmont Province (fig. 1). The Catawba River is a highly regulated system, with seven mainstem reservoirs in North Carolina. Mountain Island Lake is situated between Lake Norman upstream and Lake Wylie downstream (fig. 1) and is bounded by Cowans Ford Dam and Mountain Island Dam. Mountain Island Lake forms part of the eastern borders of Gaston and Lincoln Counties and part of the western border of Mecklenburg County.

The climate of the study area is characterized by hot, humid summers and moderate, short winters. The monthly mean air temperature ranges from about 4 degrees Celsius $\left({ }^{\circ} \mathrm{C}\right)$ in January to about $26^{\circ} \mathrm{C}$ in July (National Oceanic and Atmospheric Administration, 1998). Annual precipitation averages about 110 centimeters $(\mathrm{cm})$ (National Oceanic and Atmospheric Administration, 1998).

Geologic formations in the vicinity of Mountain Island Lake are mostly granite, with some diorite and granodiorite (LeGrand and Mundorff, 1952). Soils are predominately well-drained sandy loams with a clayey subsoil (McCachren, 1980). Topography in the area generally is characterized by low rounded uplands and streams having relatively narrow (90-180 meters [m]) flood plains.

Mountain Island Lake is a narrow, riverine reservoir (fig. 2) with a surface area of about 11.3 square kilometers $\left(\mathrm{km}^{2}\right)$, a mean depth of $4.9 \mathrm{~m}$, and a maximum depth of about $16 \mathrm{~m}$. The predominant inflow to Mountain Island Lake is water released from Lake Norman through Cowans Ford Dam. Duke Power regulates these releases and generates hydroelectric power at both Cowans Ford Dam and Mountain Island Dam. Because Mountain Island Lake is much smaller than Lake Norman (fig. 2), releases from the two reservoirs must be precisely regulated by Duke Power. For example, releases from Cowans Ford Dam sufficient to result in a 0.3-m drop in the level of Lake Norman will raise the level of Mountain Island Lake by $4 \mathrm{~m}$ if no water is released from Mountain Island Dam. Riverbend Steam Station withdraws an average of about 110 cubic meters per second $\left(\mathrm{m}^{3} / \mathrm{s}\right)$ of water from 


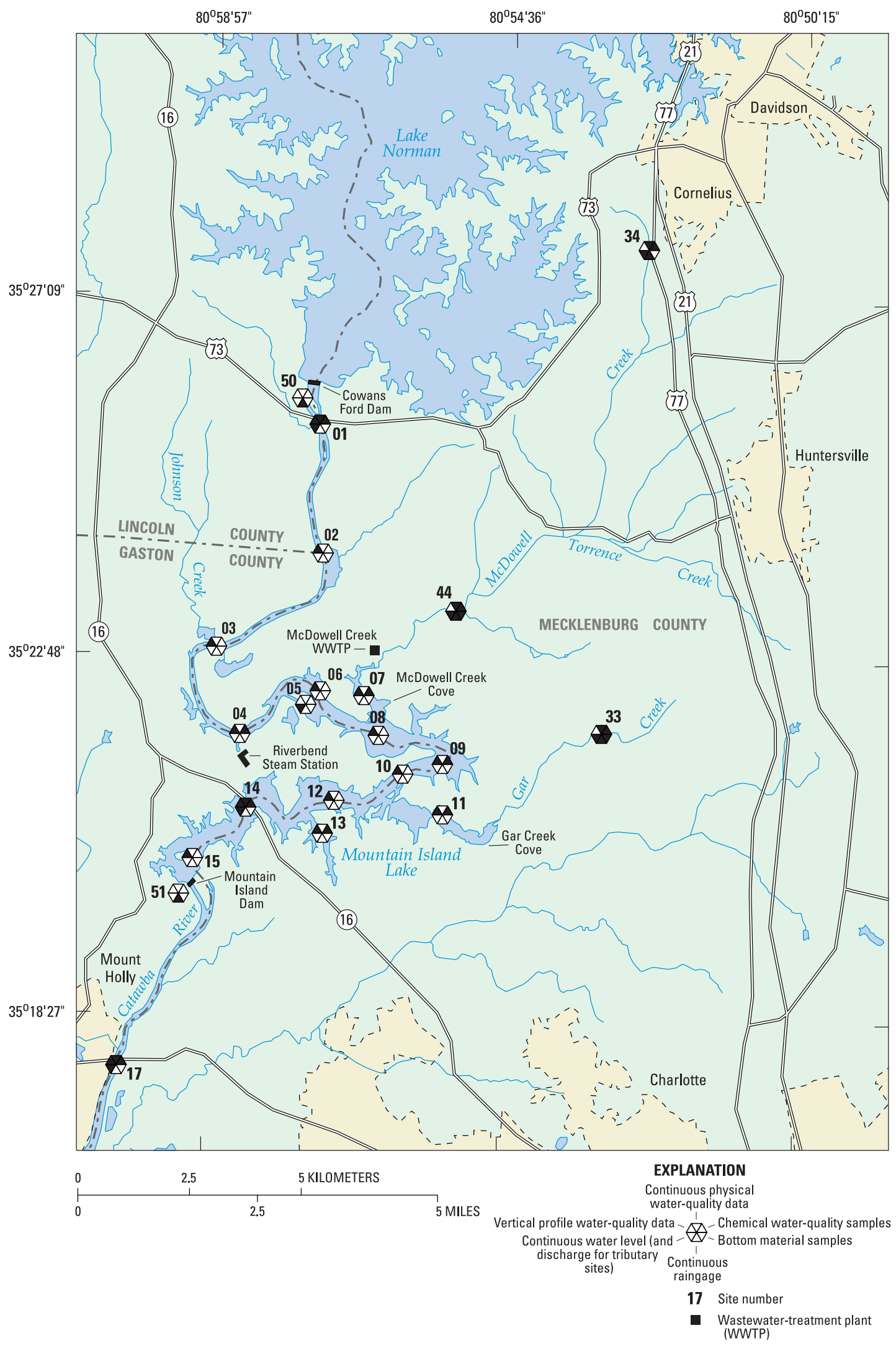

Figure 2. Mountain Island Lake, local drainage area, and data-collection sites. 
the reservoir near site 04 for cooling and steam generation and returns an equal amount to the reservoir near site 14 (fig. 2).

Major tributaries to Mountain Island Lake, other than the Catawba River, are Gar Creek and McDowell Creek in Mecklenburg County and Johnson Creek in Lincoln and Gaston Counties (fig. 2). The total area draining to the reservoir at Mountain Island Dam is $4,820 \mathrm{~km}^{2}$, but only $181 \mathrm{~km}^{2}$ of that area is downstream from Cowans Ford Dam. Mountain Island Lake also receives treated effluent from the McDowell Creek Wastewater-Treatment Plant (WWTP) and various small permitted discharges from other facilities.

Mountain Island Lake supplies water to Mecklenburg and surrounding counties and is the primary drinking-water source for more than 600,000 people in Charlotte, Gastonia, Mount Holly, and several other communities. Charlotte, the largest city in North Carolina, has a rapidly growing population. Charlotte's 1997 population of 513,000 represents an increase of about 55,000 since 1994. An additional 97,000 people live in Mecklenburg County outside the city limits of Charlotte (S. Patterson, City of Charlotte Planning Office, oral commun., 1997).

Land uses in the watershed between the Cowans Ford and Mountain Island Dams primarily are forested (woods or brush) and medium- and low-density residential, with some commercial, industrial, agricultural, and institutional uses. The upper twothirds of the lake's shoreline (upstream from McDowell Creek cove) is largely undeveloped, and the area is abundant with wildlife. Deer, osprey, herons, geese, beavers, muskrats, and turtles inhabit the forested lands and adjacent waters.

In an attempt to preserve water quality, various groups and agencies recently have focused on protecting the shoreline of Mountain Island Lake from further development. About $5 \mathrm{~km}^{2}$ on the western shore of the lake-10 kilometers $(\mathrm{km})$ of shoreline from just south of N.C. Highway 73 to the Riverbend Steam Station-was purchased in 1998, with ownership transferred to Gaston and Lincoln Counties. Current (2001) plans are for the land to become a State educational forest. On the eastern shore, Mecklenburg County Parks and Recreation Department manages several parks and a wildlife refuge, protecting about $11 \mathrm{~km}^{2}$ of land from development while providing nature-oriented recreation. Shoreline development in the lower part of Mountain Island Lake consists largely of scattered residential structures, although several planned residential communities have been constructed on the eastern shore. In 1999-2000, the City of Gastonia purchased $1.7 \mathrm{~km}^{2}$ of land on the western shore of Mountain Island Lake near Mountain Island Dam, about $300 \mathrm{~m}$ upstream from the Gastonia and Mount Holly water intakes. With this land acquisition by the City of Gastonia, about 56 percent of the shoreline of Mountain Island Lake currently (2001) is protected from future development.

\section{Previous Investigations}

One of the earliest reports of Mountain Island Lake water-quality conditions was written by Weiss and Kuenzler (1976). The reservoir was sampled at three locations in November 1973 and again in July 1974. Epilimnetic and hypolimnetic samples were collected at two of the three stations in July, but the locations of sampling stations were not provided. Based on results from the July 1974 sampling, the reservoir was classified as oligotrophic-mesotrophic. The highest reported total nitrogen (TN) concentration was 0.295 milligram per liter $(\mathrm{mg} / \mathrm{L})$. In comparison, the maximum TN concentration reported in this study (Sarver and Steiner, 1998) was $1.0 \mathrm{mg} / \mathrm{L}$ in a nearbottom sample at site 09 (fig. 2); the median TN concentration in near-bottom samples at site 09 was $0.48 \mathrm{mg} / \mathrm{L}$. The highest total phosphorus (TP) concentration reported by Weiss and Kuenzler (1976) was $0.038 \mathrm{mg} / \mathrm{L}$ in a hypolimnion sample, whereas the maximum TP concentration in this study (Sarver and Steiner, 1998) was $0.143 \mathrm{mg} / \mathrm{L}$ in a hypolimnetic sample from site 09 .

Mountain Island Lake was classified in 1981, 1982, and 1986 as mesotrophic by the North Carolina Department of Environment, Health, and Natural Resources (1992, 1995). Samples collected in 1992 and 1995 and in June-August 1997, however, indicated that the reservoir was oligotrophic (North Carolina Department of Environment and Natural Resources, 1998a). Trophic status was based on the North Carolina Trophic State Index (NC-TSI), which is calculated from measurements of Secchi disk depth and concentrations of chlorophyll $a$, total organic nitrogen, and TP. Data used to calculate the NC-TSI were collected during 1 day at 3-6 locations in the reservoir.

The Mecklenburg County Department of Environmental Protection (MCDEP) has collected samples at quarterly to monthly intervals in Mountain Island Lake since at least 1989 (Mecklenburg County 
Department of Environmental Protection, 1992). MCDEP uses the Fusilier Water Quality Index (WQI) to summarize reservoir water-quality conditions (Fusilier, 1982). The WQI ranges from 0 (worst value) to 100 (best value) and is computed from measurements of $\mathrm{pH}, \mathrm{TP}$, nitrate $\left(\mathrm{NO}_{3}\right)$, alkalinity, chlorophyll $a$, percent saturation of $\mathrm{DO}$, temperature, specific conductance, and Secchi disk depth. The WQI values for Mountain Island Lake generally have indicated "good" water quality, with index values typically in the 70's except for McDowell Creek cove, where WQI values indicate "fair" water quality (Mecklenburg County Department of Environmental Protection, 1992, 2000).

Using data from Rhodhiss Lake and Lake Hickory in the Catawba River Basin, as well as data from other North Carolina reservoirs, Bales and Childress (1999) demonstrated that the nine parameters that constitute the Fusilier WQI are not independent, whereas there was no statistically significant correlation among the four parameters used to compute the NC-TSI. Moreover, there was better agreement between trends in individual water-quality measures and trends in the NC-TSI than with the Fusilier WQI. Consequently, the NC-TSI may be the better index for classifying the trophic status of North Carolina reservoirs and summarizing water-quality conditions.

Because of continuing concerns about waterquality conditions in the McDowell Creek cove of Mountain Island Lake, including a decreasing trend in the Fusilier WQI for the cove between 1989 and 1992 (Mecklenburg County Department of Environmental Protection, 1992), the MCDEP and North Carolina Department of Environment and Natural Resources, Division of Water Quality (DWQ), conducted a joint investigation of conditions in the cove. Monthly sampling was conducted at 11 sites in Mountain Island Lake, including 3 sites in the McDowell Creek cove, during May-October 1993 and again during MayOctober 1994 (North Carolina Department of Environment, Health, and Natural Resources, 1996).

Results from the 1993-94 study indicated that chlorophyll $a$ concentrations generally decreased with distance downstream from the mouth of McDowell Creek, and only one sample had a chlorophyll $a$ concentration in excess of the North Carolina ambient water-quality standard of 40 micrograms per liter $(\mu \mathrm{g} / \mathrm{L})$ (North Carolina Department of Environment, Health, and Natural Resources, 1997). NC-TSI values indicated that eutrophic conditions existed at the upstreammost sampling station in the cove. Eutrophic conditions existed in the entire cove during part of 1993, when McDowell Creek streamflow was lower than normal and retention time in the cove was higher than normal. The degraded trophic status of the upstream part of the cove was attributed to discharges of inorganic nitrogen and TP from the McDowell Creek WWTP. The DWQ suggested that, if the McDowell Creek WWTP were to plan an expansion, water-quality modeling would be needed to determine the appropriate nutrient loadings to prevent increased algal concentrations in the cove, and that nutrient limitations for the facility might be required. In a separate report, MCDEP identified the McDowell Creek WWTP as the primary source of nutrients to McDowell Creek (Mecklenburg County Department of Environmental Protection, 1995).

One set of stormflow samples and several sets of low-flow samples were collected at more than 100 stream sites in Mecklenburg County during 1979-81 (Eddins and Crawford, 1984). In general, measured water-quality conditions in the McDowell and Gar Creek Basins were as good as any measured in the county at that time. The water quality of streams draining directly to Mountain Island Lake (Johnson, McDowell, and Gar Creeks) generally has been classified as "good" by MCDEP (Mecklenburg County Department of Environmental Protection, 1992, 2000). In fact, water-quality conditions in Gar Creek were described as being among the best in Mecklenburg County (Mecklenburg County Department of Environmental Protection, 1992, 2000). None of these three streams is included on the North Carolina 1998 final 303(d) list (North Carolina Department of Environment and Natural Resources, 1998b), which indicates that there is no current requirement for the establishment of total maximum daily loads (TMDL's) for any constituent in these streams. The $2000 \mathrm{draft}$ 303(d) list (North Carolina Department of Environment and Natural Resources, 2000) includes McDowell Creek from U.S. Highway 21 to Mountain Island Lake. The stream is listed as biologically impaired; the cause of impairment is unknown, but monitoring is planned to determine if a TMDL is required (North Carolina Department of Environment and Natural Resources, 1999a, b).

Annual yields for selected constituents were computed by using data from the period 1994-97 for one site each on McDowell Creek and Gar Creek and data from the period 1996-97 for an 
additional site on McDowell Creek (table 1; Bales and others, 1999). Continuous records of streamflow and discrete measurements of constituent concentrations were used to develop relations between flow and constituent load at each of the sites. These relations were then applied to estimate annual loads and yields at each of the sites, as well as at six other small, homogeneous land-use basins in Charlotte (Bales and others, 1999).

Annual yields of suspended sediment at these three sites were somewhat elevated relative to other stream sites in Charlotte and the Piedmont of North Carolina (Bales and others, 1999). Part of the reason for the high yields may be the unstable silt and sand channels of Gar and McDowell Creeks, particularly in the upper part of each basin. Data collected at site 44 did not include large storm events that occurred in 1995 and 1997 (Robinson, Hazell, and Garrett, 1998), which partially explains the lower yields at this site relative to the other two sites. In addition, the channel is more stable and less steep in the lower part of the McDowell Creek Basin, so less energy is available for channel degradation and sediment transport at site 44 than at site 34 . Phosphorus and metals typically adsorb onto clay particles; as a result, annual yields of TP and five metals also were somewhat high relative to those at other sites in central North Carolina. Yields of TN, total organic carbon, and biochemical oxygen demand
(BOD) at these three sites were typical of mixed landuse sites in North Carolina, and generally lower than yields from urban basins in Charlotte (Bales and others, 1999).

Water-quality data have been collected by the DWQ at site 17, located downstream from Mountain Island Dam, since at least 1973. Data from this site and other long-term sites in the Catawba River Basin were analyzed by Maluk and others (1998). The median ammonia $\left(\mathrm{NH}_{4}\right)$ concentration at site 17 for 1973-93 was near the detection limit of $0.05 \mathrm{mg} / \mathrm{L}$, and the median $\mathrm{NO}_{3}$ concentration of about $0.15 \mathrm{mg} / \mathrm{L}$ was the second lowest of 16 sites in the Catawba River Basin during 1973-93. Ninety percent of the TP values were less than $0.05 \mathrm{mg} / \mathrm{L}$ during the period. Both $\mathrm{NH}_{4}$ and TP exhibited statistically significant decreasing trends during 1973-93, but there were no trends in $\mathrm{NO}_{3}$ and total Kjeldahl nitrogen (TKN) concentrations.

Ammonia and $\mathrm{NO}_{3}$ varied seasonally, but TP and TKN exhibited no statistically significant seasonal variation.

\section{Acknowledgments}

The assistance of H. Forrest of CharlotteMecklenburg Utilities throughout the investigation is gratefully acknowledged. M.E. Lieber of the North Carolina Division of Water Quality supplied compliance monitoring data for point-source

Table 1. Annual average load of selected constituents in streams at two sites on McDowell Creek (sites 34 and 44 ) and one site on Gar Creek (site 33), 1994-97 (Bales and others, 1999), and McDowell Creek Wastewater-Treatment Plant, $1996-97$ [WWTP, wastewater-treatment plant; $\mathrm{kg} / \mathrm{yr}$, kilogram per year; $\left(\mathrm{kg} / \mathrm{km}^{2}\right) / \mathrm{yr}$, kilogram per square kilometer per year; —, no data; $\mathrm{km}^{2}$, square kilometer; NA, not applicable]

\begin{tabular}{|c|c|c|c|c|c|c|c|}
\hline \multirow{3}{*}{ Constituent } & \multicolumn{7}{|c|}{ Site number or location (fig. 2) and period of record } \\
\hline & \multicolumn{2}{|c|}{$\begin{array}{c}\text { Site 34, } \\
\text { 6/94-9/97 }\end{array}$} & \multicolumn{2}{|c|}{$\begin{array}{c}\text { Site 44, } \\
\text { 11/96-9/97 }\end{array}$} & \multicolumn{2}{|c|}{$\begin{array}{c}\text { Site 33, } \\
6 / 94-9 / 97\end{array}$} & \multirow{2}{*}{$\begin{array}{c}\text { McDowel } \\
\text { Creek } \\
\text { WWTP, } \\
\text { 5/96-4/97 } \\
\text { kg/yr } \\
\end{array}$} \\
\hline & $\mathbf{k g} / \mathbf{y r}$ & $\left(\mathrm{kg} / \mathrm{km}^{2}\right) / \mathrm{yr}$ & $\mathbf{k g} / \mathbf{y r}$ & $\left(\mathrm{kg} / \mathrm{km}^{2}\right) / \mathrm{yr}$ & $\mathbf{k g} / \mathbf{y r}$ & $\left(\mathrm{kg} / \mathrm{km}^{2}\right) / \mathbf{y r}$ & \\
\hline Drainage area $\left(\mathrm{km}^{2}\right)$ & 6.10 & - & 68.1 & - & 6.92 & - & NA \\
\hline Suspended sediment & $4,450,000$ & 729,000 & $13,400,000$ & 197,000 & $5,810,000$ & 840,000 & 41,600 \\
\hline Total nitrogen & 5,450 & 893 & 47,900 & 703 & 8,540 & 1,230 & 46,600 \\
\hline Total phosphorus & 1,820 & 298 & 9,810 & 144 & 1,360 & 196 & 7,420 \\
\hline $\begin{array}{l}\text { Biochemical oxygen } \\
\text { demand }\end{array}$ & 20,700 & 3,390 & 148,000 & 2,170 & 12,500 & 1,810 & 12,200 \\
\hline Total organic carbon & 42,900 & 7,030 & 370,000 & 5,430 & 44,400 & 6,420 & - \\
\hline Chromium & 78 & 13 & 454 & 6.7 & 55 & 7.9 & - \\
\hline Copper & 110 & 18 & 999 & 15 & 145 & 21 & 8 \\
\hline Lead & 50 & 8.2 & 193 & 2.8 & 27 & 3.9 & 27 \\
\hline Nickel & 28 & 4.6 & 192 & 2.8 & 19 & 2.7 & - \\
\hline Zinc & 122 & 20 & 1,725 & 25 & 74 & 11 & 104 \\
\hline
\end{tabular}


dischargers in the study area. D. Owen, also of the North Carolina Division of Water Quality, provided water-quality results from the State's ambient reservoir monitoring network. Water withdrawal data were provided by T. Huffstickler (Charlotte-Mecklenburg Utilities), M. Bynum (City of Gastonia), and E. Nichols (City of Mount Holly). T. Ziegler, J.E. Smith, and J. Knight of Duke Power supplied various information about Duke Power operations, including release data from dams and other facilities on Mountain Island Lake. T. Cole of the U.S. Army Corps of Engineers provided valuable guidance and assistance on the CE-QUAL-W2 model.

\section{METHODS OF DATA COLLECTION}

Data collection began in April 1996 and continued through September 1997. Data were collected from a total of 21 sites located in the mainstem and coves of Mountain Island Lake, two tributary streams (McDowell Creek and Gar Creek), and the Catawba River downstream from Mountain Island Dam (fig. 2; table 2).

Fifteen-minute average water level was recorded at three sites in Mountain Island Lake and at one site in the Catawba River downstream from Mountain Island Dam. Water level was recorded every 5 minutes at the

Table 2. Data-collection network for the Mountain Island Lake study

[x, data collected; - , data not collected; SR, secondary road. Physical water-quality characteristics and chemical constituents are listed in text]

\begin{tabular}{|c|c|c|c|c|c|c|c|}
\hline \multirow{2}{*}{$\begin{array}{l}\text { Site no. } \\
\text { (fig. 2) }\end{array}$} & \multirow{2}{*}{$\begin{array}{l}\text { Site location and USGS downstream order } \\
\text { identification number }\end{array}$} & \multicolumn{2}{|c|}{$\begin{array}{l}\text { Type of hydrologic } \\
\text { measurement }\end{array}$} & \multicolumn{3}{|c|}{ Type of water-quality data } & \multirow{2}{*}{$\begin{array}{c}\text { Type of } \\
\text { meteorologic } \\
\text { data }\end{array}$} \\
\hline & & $\begin{array}{l}\text { Water } \\
\text { level }\end{array}$ & $\begin{array}{l}\text { Dis- } \\
\text { charge }\end{array}$ & $\begin{array}{c}\text { Physi- } \\
\text { cal }\end{array}$ & $\begin{array}{c}\text { Chemi- } \\
\text { cal }\end{array}$ & $\begin{array}{c}\text { Bottom } \\
\text { material }\end{array}$ & \\
\hline \multicolumn{8}{|c|}{ Mountain Island Lake sites } \\
\hline 01 & Catawba River at N.C. 73 near Hicks Crossroads, 0214264800 & $\mathrm{x}$ & - & $\mathrm{x}$ & $\mathrm{x}$ & - & - \\
\hline 02 & Catawba River near Allison Ferry, 0214264813 & - & - & $\mathrm{x}$ & - & - & - \\
\hline 03 & $\begin{array}{l}\text { Catawba River above Johnson Creek near Allison Ferry, } \\
0214264830\end{array}$ & - & - & $\mathrm{x}$ & - & - & - \\
\hline 04 & Catawba River at Power Plant near Shuffletown, 0214264900 & - & - & $\mathrm{x}$ & $\mathrm{x}$ & - & - \\
\hline 05 & $\begin{array}{l}\text { Catawba River at Riverbend Steam Station near Shuffletown, } \\
0214264950\end{array}$ & $\mathrm{x}$ & - & - & - & - & - \\
\hline 06 & $\begin{array}{l}\text { Catawba River at Mountain Island Lake near Shuffletown, } \\
0214264960\end{array}$ & - & - & $\mathrm{x}$ & - & - & - \\
\hline 08 & $\begin{array}{l}\text { Catawba River near mouth McDowell Creek near Shuffletown, } \\
0214266026\end{array}$ & - & - & $\mathrm{x}$ & - & - & - \\
\hline 09 & $\begin{array}{l}\text { Catawba River below McDowell Creek near Shuffletown, } \\
0214266045\end{array}$ & - & - & $\mathrm{x}$ & $\mathrm{x}$ & - & - \\
\hline 10 & Catawba River above Gar Creek near Shuffletown, 0214266055 & - & - & $\mathrm{x}$ & - & - & - \\
\hline 12 & Catawba River below Gar Creek near Shuffletown, 0214266900 & - & - & $\mathrm{x}$ & - & - & - \\
\hline 14 & Catawba River at N.C. 16 near Shuffletown, 0214267200 & $\mathrm{x}$ & - & $\mathrm{x}$ & $\mathrm{x}$ & - & - \\
\hline 15 & Catawba River above Dam near Shuffletown, 0214267598 & $\mathrm{x}^{\mathrm{a}}$ & - & $\mathrm{x}$ & - & - & - \\
\hline \multicolumn{8}{|c|}{ Mountain Island Lake cove sites } \\
\hline 07 & McDowell Creek near Shuffletown, 0214266024 & - & - & $\mathrm{x}$ & $\mathrm{x}$ & - & - \\
\hline 11 & Gar Creek near Shuffletown, 0214266250 & - & - & $\mathrm{x}$ & $\mathrm{x}$ & - & - \\
\hline 13 & Catawba River at Inlet near Shuffletown, 0214267000 & - & - & $\mathrm{x}$ & $\mathrm{x}$ & - & - \\
\hline \multicolumn{8}{|c|}{ Catawba River site } \\
\hline 17 & Catawba River at Highway 27 at Mount Holly, 02142808 & $\mathrm{x}$ & - & $\mathrm{x}$ & $\mathrm{x}$ & - & - \\
\hline \multicolumn{8}{|c|}{ Tributary sites } \\
\hline 33 & Gar Creek at SR 2120 near Oakdale, 0214266075 & $\mathrm{x}$ & $\mathrm{x}$ & $\mathrm{x}$ & $\mathrm{x}$ & $\mathrm{x}$ & rainfall \\
\hline 34 & McDowell Creek at SR 2147 near Cornelius, 02142651 & $\mathrm{x}$ & $\mathrm{x}$ & $\mathrm{x}$ & $\mathrm{x}$ & - & rainfall \\
\hline 44 & McDowell Creek near Charlotte, 0214266000 & $\mathrm{x}$ & $\mathrm{x}$ & $\mathrm{x}$ & $\mathrm{x}$ & $\mathrm{x}$ & rainfall \\
\hline \multicolumn{8}{|c|}{ Additional sites } \\
\hline 50 & Cowans Ford Dam, 352555080574445 & - & $\mathrm{x}^{\mathrm{a}}$ & - & - & - & rainfall \\
\hline 51 & Catawba River at Mountain Island Dam, 0214267600 & - & $\mathrm{x}^{\mathrm{a}}$ & - & - & - & $\begin{array}{l}\text { rainfall, } \\
\text { temperature, } \\
\text { solar radiation }\end{array}$ \\
\hline
\end{tabular}

${ }^{\mathrm{a}}$ Measured by Duke Power. 
McDowell Creek and Gar Creek tributary sites, and discharge was computed by using stage-discharge relations. Hourly estimates of outflow from Cowans Ford Dam and Mountain Island Dam, and hourly water-level data from the forebay and tailrace of each dam were provided by Duke Power. Rainfall was recorded by the USGS at 5-minute intervals at five raingages in the study area (fig. 2; table 2).

Water-quality data collected in Mountain Island Lake include 15-minute interval measurements of water temperature, DO concentration, and specific conductance at the headwaters of the reservoir (site 1, mid-depth), in the reservoir (site 14, near surface and near bottom), and in the Catawba River downstream from Mountain Island Dam (site 17, mid-depth); vertical profiles of water temperature, DO concentration, specific conductance, and $\mathrm{pH}$ periodically measured at 15 sites throughout the reservoir; and chemical water-quality constituent concentrations determined from samples collected at 8 reservoir sites (fig. 2; table 2). At reservoir sites, water-quality samples were collected from two depths to characterize water-quality conditions $0.5 \mathrm{~m}$ below the water surface and $1.0 \mathrm{~m}$ above the reservoir bottom. Vertical profiles were measured and water-quality samples were collected for analysis generally twice monthly from May 1996 to July 1996 and about monthly from August 1996 to September 1997.

Water-quality data collected from the McDowell Creek and Gar Creek tributary sites included measurements of water temperature and specific conductance at 5-minute intervals. Chemical water-quality constituent concentrations were determined from samples collected quarterly during storm events and annually during nonstorm conditions. Detailed sampling, analytical methodologies, and quality-assurance procedures are described by Sarver and Steiner (1998) for the reservoir and cove sites, and by Robinson, Hazell, and Garrett (1998) for the tributary and rainfall sites.

\section{AMBIENT CONDITIONS}

Hydrologic and water-quality conditions during the study period (April 1996-September 1997) are summarized in this section. An estimated water balance for Mountain Island Lake is presented. Spatial and temporal variations in water quality are described, and where applicable, results are compared to State water- quality standards and to conditions observed in similar systems.

\section{Hydrologic Conditions}

Long-term average (1960-90) precipitation at the Charlotte/Douglas International Airport, located about $15 \mathrm{~km}$ south of Mountain Island Lake, ranges from 6.81 to $11.25 \mathrm{~cm}$ per month (National Oceanic and Atmospheric Administration, 1998). During this investigation, monthly precipitation at Charlotte/ Douglas International Airport ranged from $2.79 \mathrm{~cm}$ (August 1997) to $22.71 \mathrm{~cm}$ (July 1997; fig. 3). Monthly rainfall totals recorded by the five individual raingages operated by the USGS in the study area (table 2) ranged from $0.10 \mathrm{~cm}$ (site 51, August 1997) to $19.05 \mathrm{~cm}$ (site 33, July 1997). The mean monthly rainfall from the five study area raingages ranged from $1.02 \mathrm{~cm}$ (August 1997) to $16.81 \mathrm{~cm}$ (July 1997; fig. 3). Rainfall generally was slightly below normal during the fall 1996 and winter 1997. Mean rainfall for the study area was more than $5 \mathrm{~cm}$ above normal in June 1996 (+5.13), April 1997 (+8.23), and July 1997 (+6.85), and more than $5 \mathrm{~cm}$ below normal in May 1996 (-7.26), May 1997 (-6.65), and August 1997 (-8.45).

Daily mean discharge at Gar Creek site 33 ranged from 0.004 to $2.6 \mathrm{~m}^{3} / \mathrm{s}$ from April 1996 to September 1997, with a mean daily discharge of $0.067 \mathrm{~m}^{3} / \mathrm{s}$ during the study period. At McDowell Creek site 34, daily mean discharge ranged from 0.007 to $3.14 \mathrm{~m}^{3} / \mathrm{s}$, with a period of record mean value of $0.083 \mathrm{~m}^{3} / \mathrm{s}$. Daily mean discharge at McDowell Creek site 44 (November 26, 1996-September 30, 1997) ranged from 0.074 to $13.5 \mathrm{~m}^{3} / \mathrm{s}$, with a mean of $0.84 \mathrm{~m}^{3} / \mathrm{s}$. Streamflow at the McDowell Creek and Gar Creek tributary sites typically reflected precipitation patterns. Maximum daily mean discharge during the study period occurred on July 23, 1997, at all three sites in conjunction with a storm having rainfall amounts in the study area ranging from 10.19 to $15.54 \mathrm{~cm}$. Daily mean discharges for the McDowell Creek and Gar Creek sites are published in Robinson, Hazell, and Garrett (1998).

Discharge into Mountain Island Lake predominately is controlled by upstream releases from Lake Norman through Cowans Ford Dam (fig. 2). Hourly discharge from Cowans Ford Dam during the study ranged from 2.27 to $1,170 \mathrm{~m}^{3} / \mathrm{s}$. Discharge through Cowans Ford Dam, however, was intermittent, with releases occurring 28 percent of the time from 


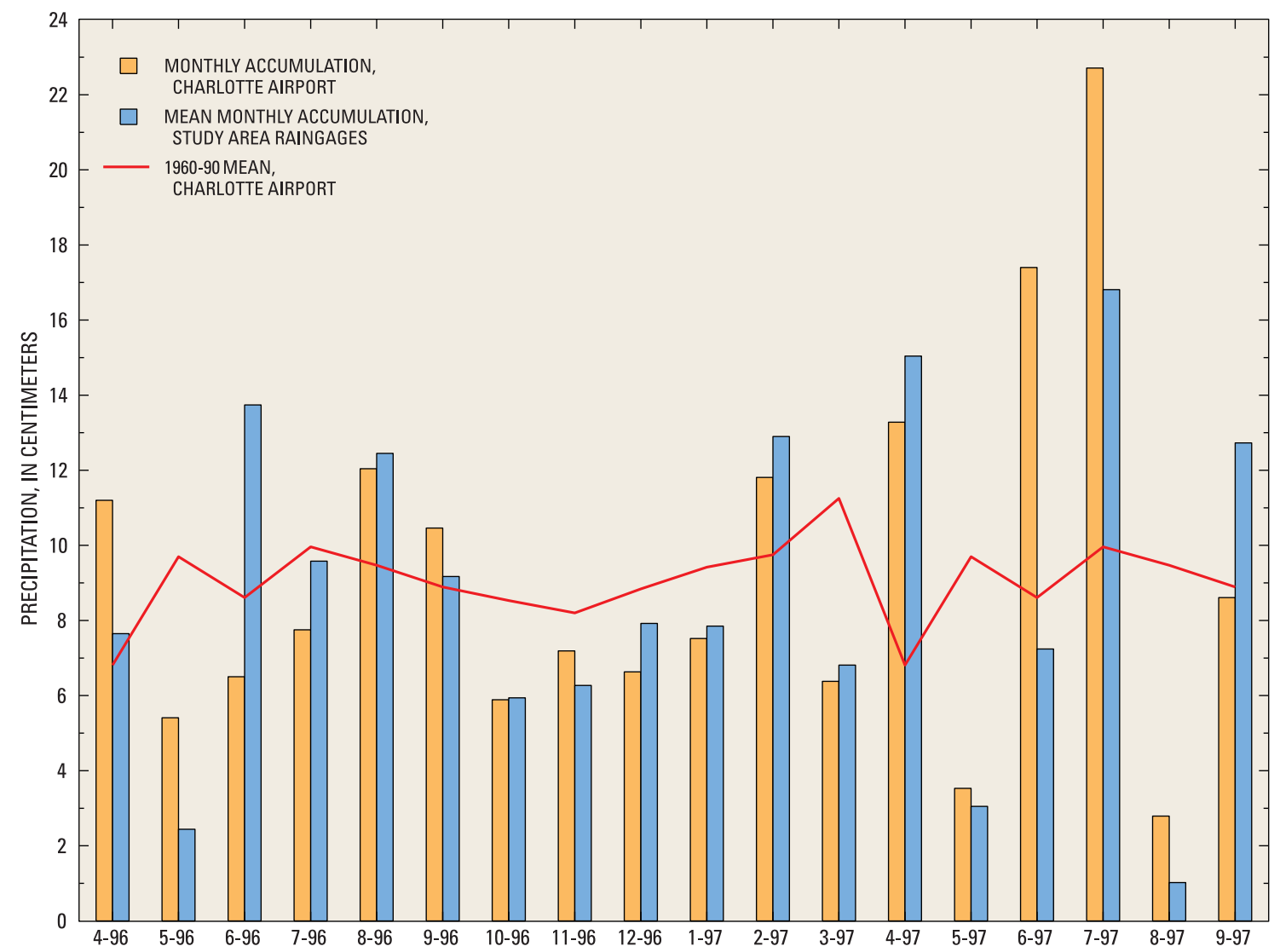

Figure 3. Monthly precipitation from April 1996 to September 1997 near Mountain Island Lake and 1960-90 at Charlotte/Douglas International Airport.

September 1996 to August 1997 (fig. 4). Discharge when the dam was closed (leakage) was assumed to be $2.27 \mathrm{~m}^{3} / \mathrm{s}$ (T. Ziegler, Duke Power, written commun., August 1998). Releases were made at Cowans Ford Dam more frequently in winter and spring and less frequently in summer and fall (fig. 5). Even in winter, however, there were no releases during at least 58 percent of the time (December 1996). There were no releases 87 percent of the time during September 1997.

As a result of the hydropower operations, discharge in the Catawba River downstream from Cowans Ford Dam was equal to the leakage rate $\left(2.27 \mathrm{~m}^{3} / \mathrm{s}\right) 72$ percent of the time during the 12-month period between September 1996 and August 1997. In addition, during most summer and fall months, discharge downstream from the dam was equal to the leakage rate 75 percent of the time (fig. 6). Monthly 90th-percentile discharges from Cowans Ford Dam ranged from $95 \mathrm{~m}^{3} / \mathrm{s}$ ( 90 percent of the time discharge in the river downstream from the dam was $95 \mathrm{~m}^{3} / \mathrm{s}$ or less) in September 1997 to 464 m³/s in December 1996. From September 1996 to August 1997, 20 percent of hourly discharges from Cowans Ford Dam were greater than $170 \mathrm{~m}^{3} / \mathrm{s}$, and 10 percent were greater than $297 \mathrm{~m}^{3} / \mathrm{s}$ (fig. 4).

Discharge from Mountain Island Dam (fig. 2) was more continuous and occurred at a lower rate than discharge from Cowans Ford Dam (fig. 4). During the study, hourly discharge in the Catawba River downstream from Mountain Island Dam ranged from $2.27 \mathrm{~m}^{3} / \mathrm{s}$, primarily leakage (T. Ziegler, Duke Power, written commun., August 1998), to $289 \mathrm{~m}^{3} / \mathrm{s}$. During the 12-month period September 1996-August 1997 (fig. 4), there were no releases from Mountain Island Dam 26 percent of the time compared to 72 percent of the time at Cowans Ford Dam. Mountain Island Dam release patterns, however, mirrored those at Cowans Ford Dam (fig. 5), with more frequent releases in winter and spring. On a monthly basis, there were no releases from Mountain Island Dam between 10 percent (December 1996) and 47 percent (May 1996) of the time. Median discharge downstream from Mountain Island Dam was $45 \mathrm{~m}^{3} / \mathrm{s}$. The magnitude of the 75th- and 90th-percentile monthly 


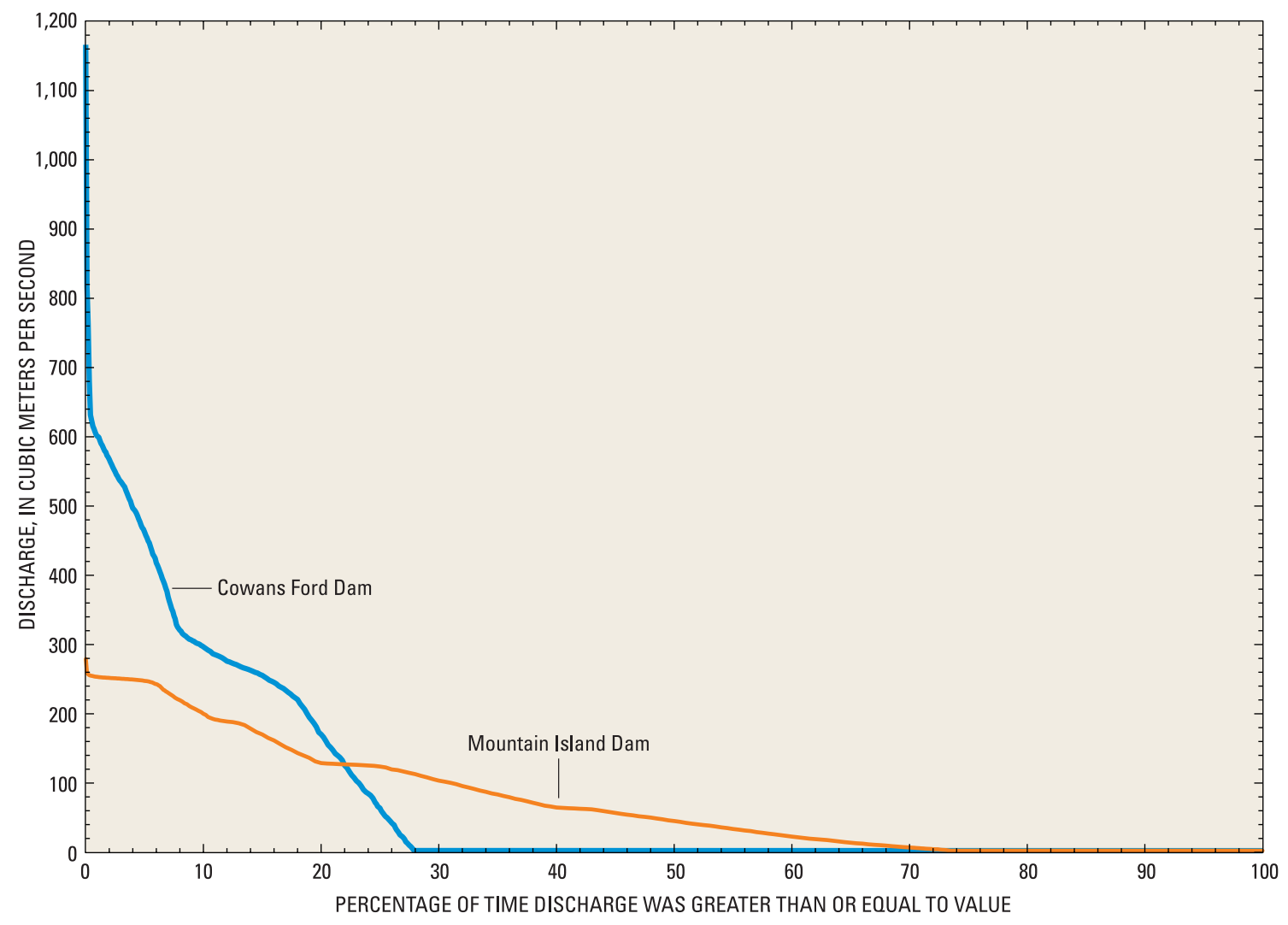

Figure 4. Discharge durations for the Catawba River at Cowans Ford Dam and Catawba River at Mountain Island Dam, September 1, 1996-August 31, 1997.

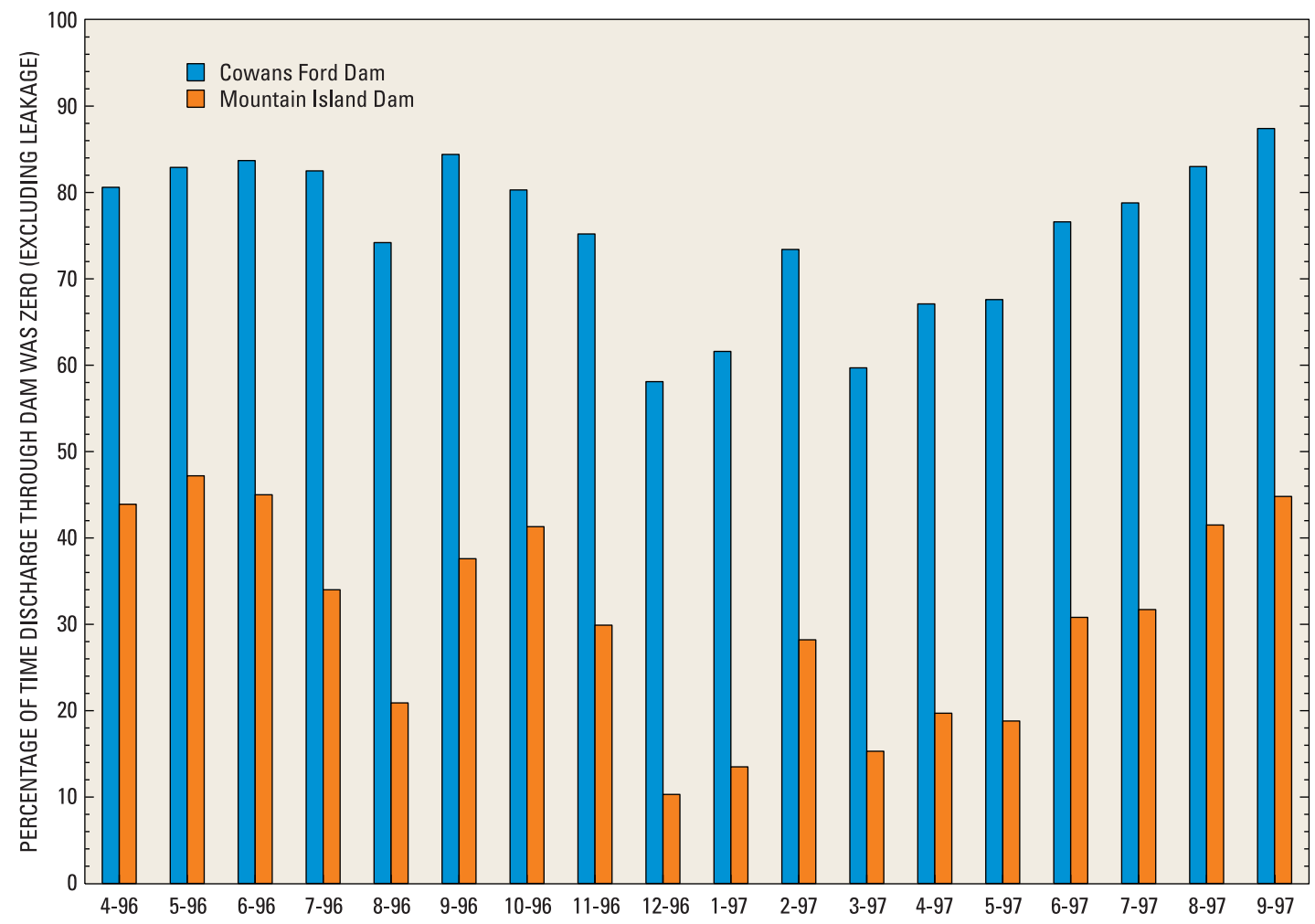

Figure 5. Percentage of time Cowans Ford Dam and Mountain Island Dam were closed, April 1996-September 1997. 


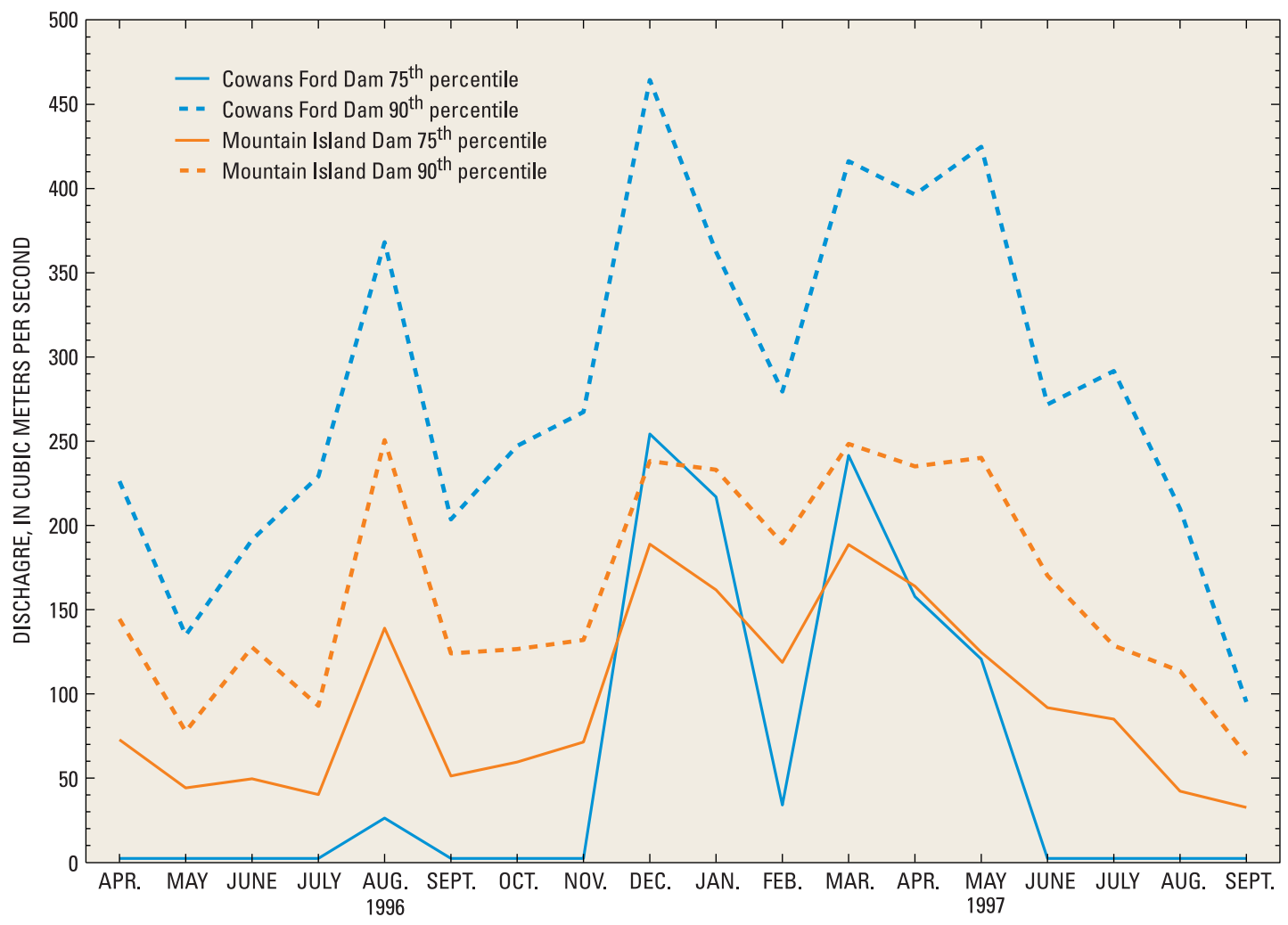

Figure 6. Selected percentiles of discharge from Cowans Ford Dam and Mountain Island Dam, April 1996-September 1997.

discharges from Mountain Island Dam were between the magnitude of the 75th- and 90th-percentile releases from Cowans Ford Dam, except for 3 months during the study (fig. 6). From September 1996 to August 1997, 20 percent of the hourly discharge values from Mountain Island Dam were greater than $129 \mathrm{~m}^{3} / \mathrm{s}$, and 10 percent were greater than $200 \mathrm{~m}^{3} / \mathrm{s}$ (fig. 4).

A water balance computed for Mountain Island Lake for water year 1997 included 10 inputs to and 6 withdrawals from the reservoir (table 3). Major inputs included discharge from Cowans Ford Dam (2.47 billion cubic meters $\left[\mathrm{m}^{3}\right]$ ) and cooling water discharge from Riverbend Steam Station ( 0.347 billion $\mathrm{m}^{3}$ ). McDowell Creek streamflow (site 44) added 0.026 billion $\mathrm{m}^{3}$ of water to the lake, with McDowell Creek WWTP contributing an order of magnitude less $\left(0.003\right.$ billion $\left.\mathrm{m}^{3}\right)$. Major withdrawals from the lake consisted of outflow from Mountain Island Dam $\left(2.23\right.$ billion $\left.\mathrm{m}^{3}\right)$ and water extracted for use by Riverbend Steam Station ( 0.354 billion $\left.\mathrm{m}^{3}\right)$. Total municipal water withdrawals were 0.153 billion $\mathrm{m}^{3}$, with Charlotte-Mecklenburg Utilities withdrawing 0.117 billion $\mathrm{m}^{3}$. Total estimated inputs to Mountain
Island Lake (2.87 billion $\mathrm{m}^{3}$ ) during October 1996September 1997 differed from total estimated withdrawals $\left(2.75\right.$ billion $\mathrm{m}^{3}$ ) by less than 5 percent, which is within the accuracy of the data used in the water balance.

Mountain Island Lake levels fluctuated widely, typically exhibiting one or more daily peaks in response to discharge from Cowans Ford Dam (fig. 7). During October 1995-September 1997 (the two complete years when water-level data were available), daily water-level fluctuations at site 01 (fig. 2) ranged from 0.32 to $2.73 \mathrm{~m}$, with a median daily fluctuation of $0.92 \mathrm{~m}$. Sixty-eight percent of the daily water-level fluctuations at site 01 ranged between 0.52 and $1.53 \mathrm{~m}$ (plus or minus one standard deviation from the mean). Ten percent of the fluctuations were greater than $1.71 \mathrm{~m}$. Water levels at site 14 (fig. 2) varied less than at site 01 , with daily fluctuations at site 14 ranging from 0.08 to $0.98 \mathrm{~m}$. During October 1995-September 1997, median daily water-level fluctuation at site 14 was $0.31 \mathrm{~m}$, with 68 percent of the fluctuations ranging between 0.17 and $0.52 \mathrm{~m}$ (plus or minus one standard deviation from the mean). Ten percent of the daily 
Table 3. Estimated water balance for Mountain Island Lake, October 1996-September 1997 $\left[\mathrm{m}^{3}\right.$, cubic meter; NPDES, National Pollutant Discharge Elimination Program; USGS, U.S. Geological Survey]

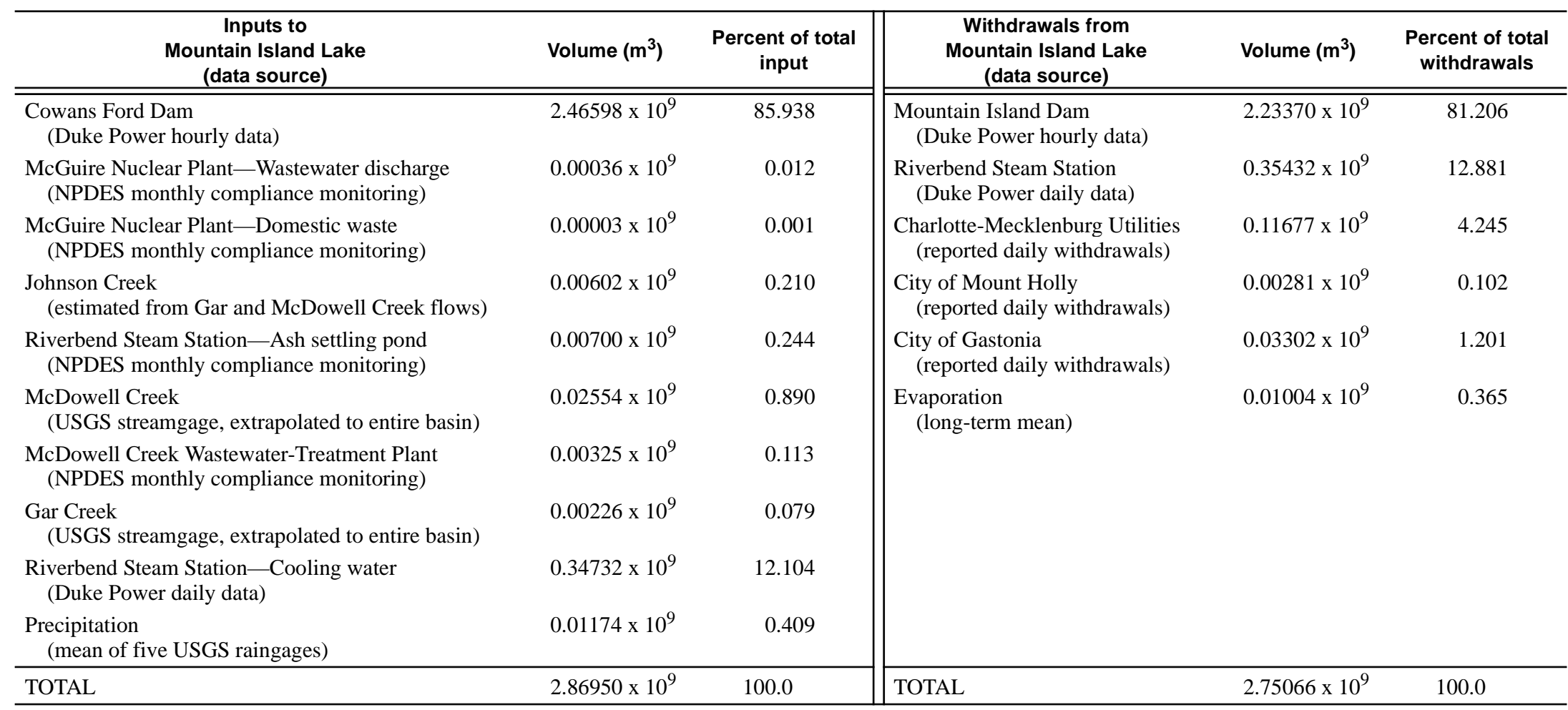



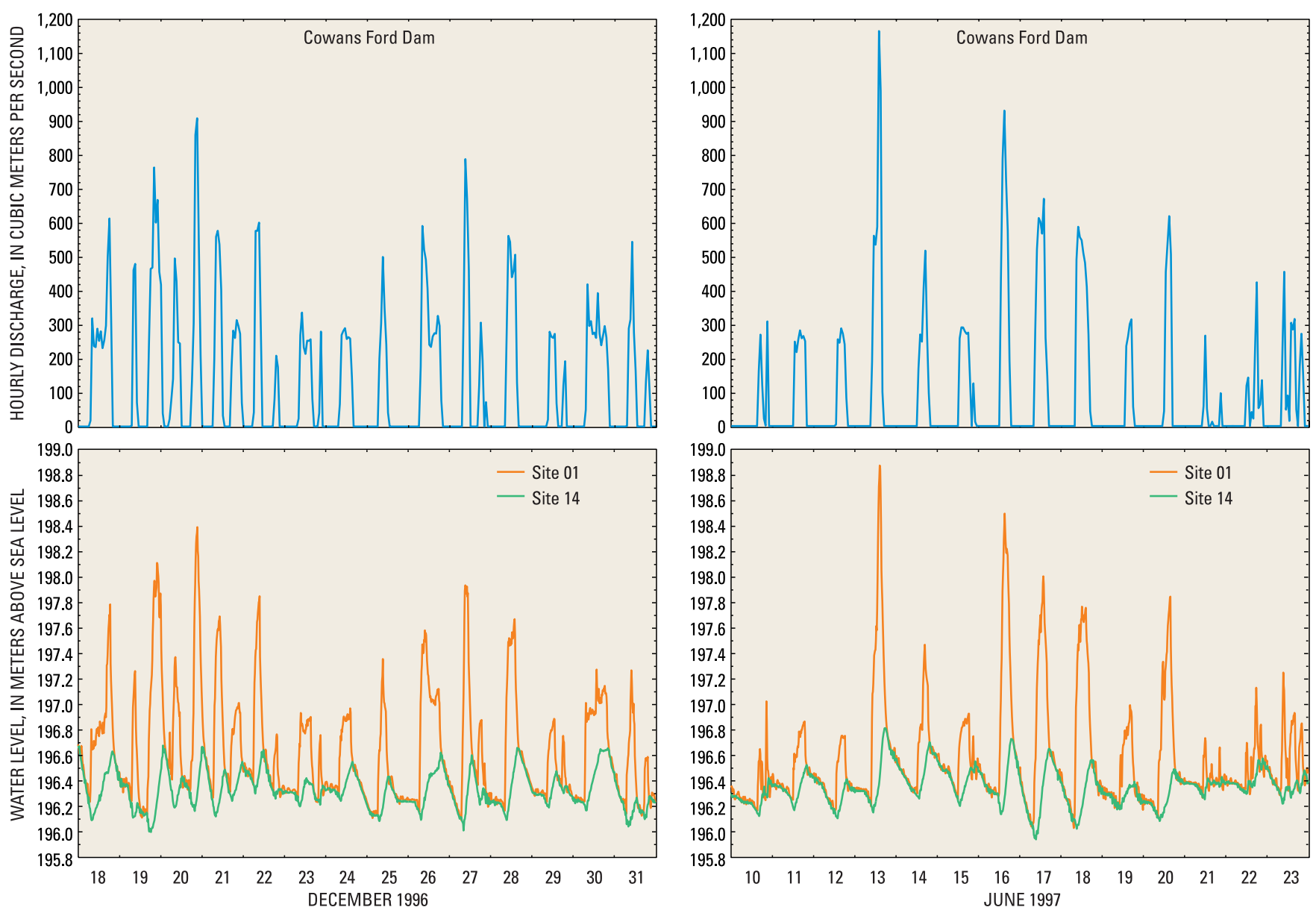

Figure 7. Discharge from Cowans Ford Dam and water level at sites 01 and 14, December 18-31, 1996, and June 10-23, 1997.

water-level fluctuations at site 14 were greater than $0.58 \mathrm{~m}$. The occurrence of water-level peaks at site 14 generally lagged those at site 01 by about 1 to 4 hours, depending on the magnitude and duration of discharge from Cowans Ford Dam (fig. 7).

\section{Physical Water-Quality Characteristics}

The flow and circulation dynamics of Mountain Island Lake are controlled primarily by anthropogenic forces - controlled inflows and outflows - in contrast to most Piedmont reservoirs that have a longer theoretical residence time than Mountain Island Lake. Physical water-quality characteristics (water temperature, $\mathrm{DO}$ concentration, $\mathrm{pH}$, and specific conductance) in Mountain Island Lake varied seasonally and spatially to some extent, but were controlled primarily by inflow from Lake Norman through Cowans Ford Dam and selected point-source discharges. Weather and in-lake biochemical processes influenced the physical water-quality characteristics of Mountain Island Lake to a lesser extent.

Cowans Ford Dam is capable of releasing water at a much greater rate than Mountain Island Dam. During the study, Cowans Ford Dam had releases in excess of $1,000 \mathrm{~m}^{3} / \mathrm{s}$, whereas the maximum release rate from Mountain Island Dam was less than $300 \mathrm{~m}^{3} / \mathrm{s}$. Average theoretical water residence time in Mountain Island Lake, computed from the volume of the reservoir and the mean annual inflow, is 12 days; however, during periods of high flows from Cowans Ford Dam, the theoretical residence time can be less than a day.

Water temperature, DO concentration, and specific conductance were monitored at 15-minute intervals at three sites (sites 01,14 , and 17). In addition, 
vertical profiles of water temperature, DO concentration, specific conductance, and $\mathrm{pH}$ were measured periodically to characterize patterns of stratification at 15 sites, including 11 sites in the reservoir mainstem (fig. 8), 3 sites in reservoir coves, and 1 site on the Catawba River downstream from Mountain Island Dam (table 2; fig. 2). The following discussion focuses primarily on characteristics measured at the continuous-monitoring sites, the 11 mainstem vertical-profile sites, and to a lesser extent, the cove sites.

\section{Water Temperature}

The thermal structure of Mountain Island Lake is dominated primarily by the temperature of inflows to the lake, rather than heat transfer from solar radiation. The major influence on water temperature in the headwaters of Mountain Island Lake is the release of water from Lake Norman through Cowans Ford Dam. Water from Lake Norman is released through a subsurface outlet in Cowans Ford Dam. The outlet extends vertically from 15 to $29 \mathrm{~m}$ below the full pool elevation of Lake Norman (T. Ziegler, Duke Power, written commun., September 21, 1998). However, because of a submerged skimmer weir located about $90 \mathrm{~m}$ upstream from Cowans Ford Dam, water released through the dam is drawn from the upper 6-11 $\mathrm{m}$ of Lake Norman. The second major influence on the thermal structure of Mountain Island Lake is the release of water to the lake from Duke Power's Riverbend Steam Station. The steam station withdraws water from the lake near site 04 (fig. 2) and releases condenser cooling water (at temperatures greater than ambient) back into the lake about $0.5 \mathrm{~km}$ upstream from site 14 .

Water temperatures were recorded near middepth at site 01 , located about $0.8 \mathrm{~km}$ downstream from Cowans Ford Dam (fig. 2). Periodically measured vertical profiles exhibited essentially no top-to-bottom temperature variation at this site. Temperatures at site 01 ranged from 7.8 to $29.8^{\circ} \mathrm{C}$. During September 1996-August 1997, the median water temperature at site 01 was $17.3{ }^{\circ} \mathrm{C}$ (fig. 9).

During the summer, water temperature at site 01 responded to the cyclical nature of discharge from Cowans Ford Dam. Following a period of no discharge from Cowans Ford Dam, as water level rose in response to the initiation of discharge from Cowans Ford Dam, water temperature typically exhibited a

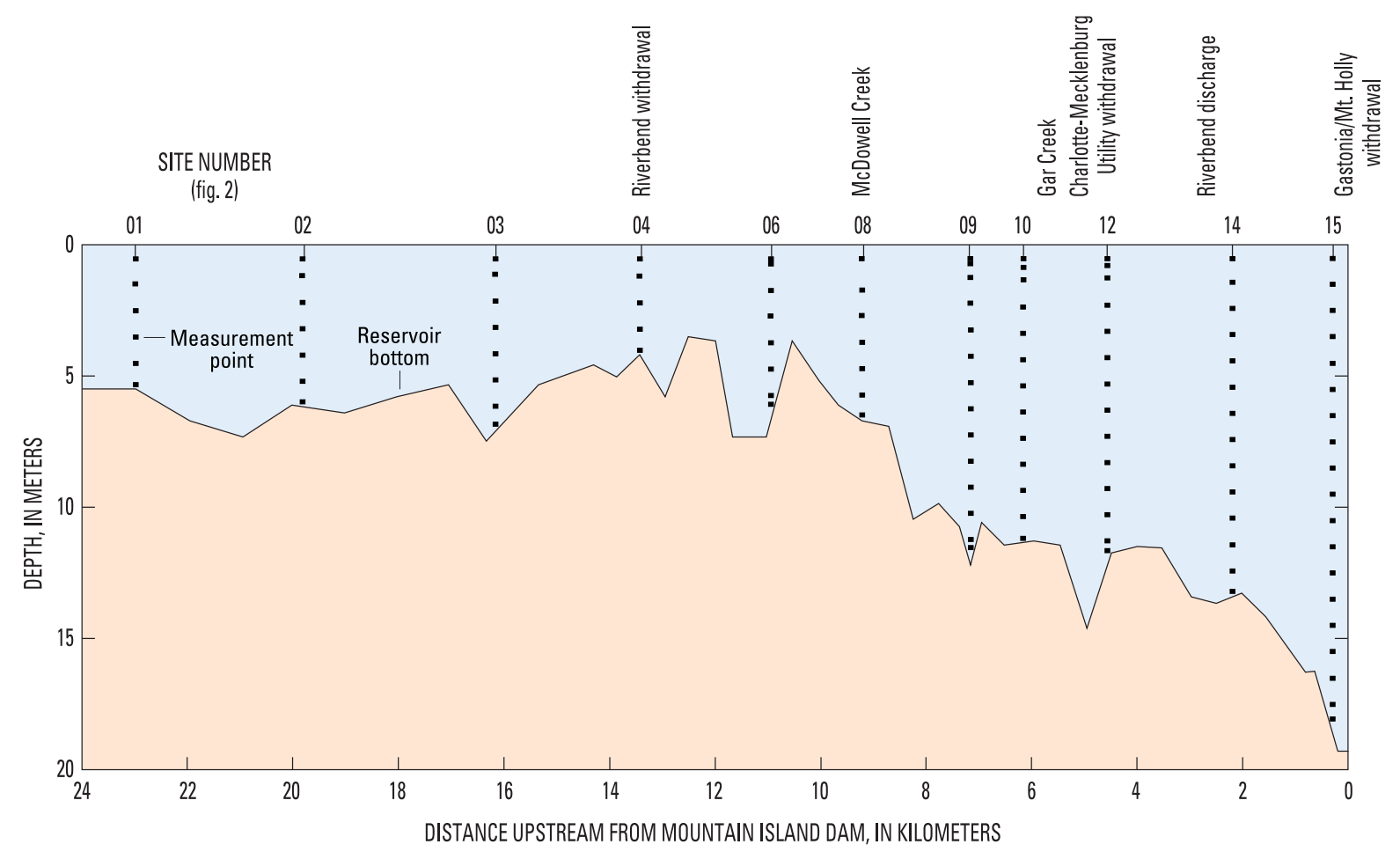

Figure 8. Diagram of Mountain Island Lake mainstem data-collection points for vertical profile water-quality data. 


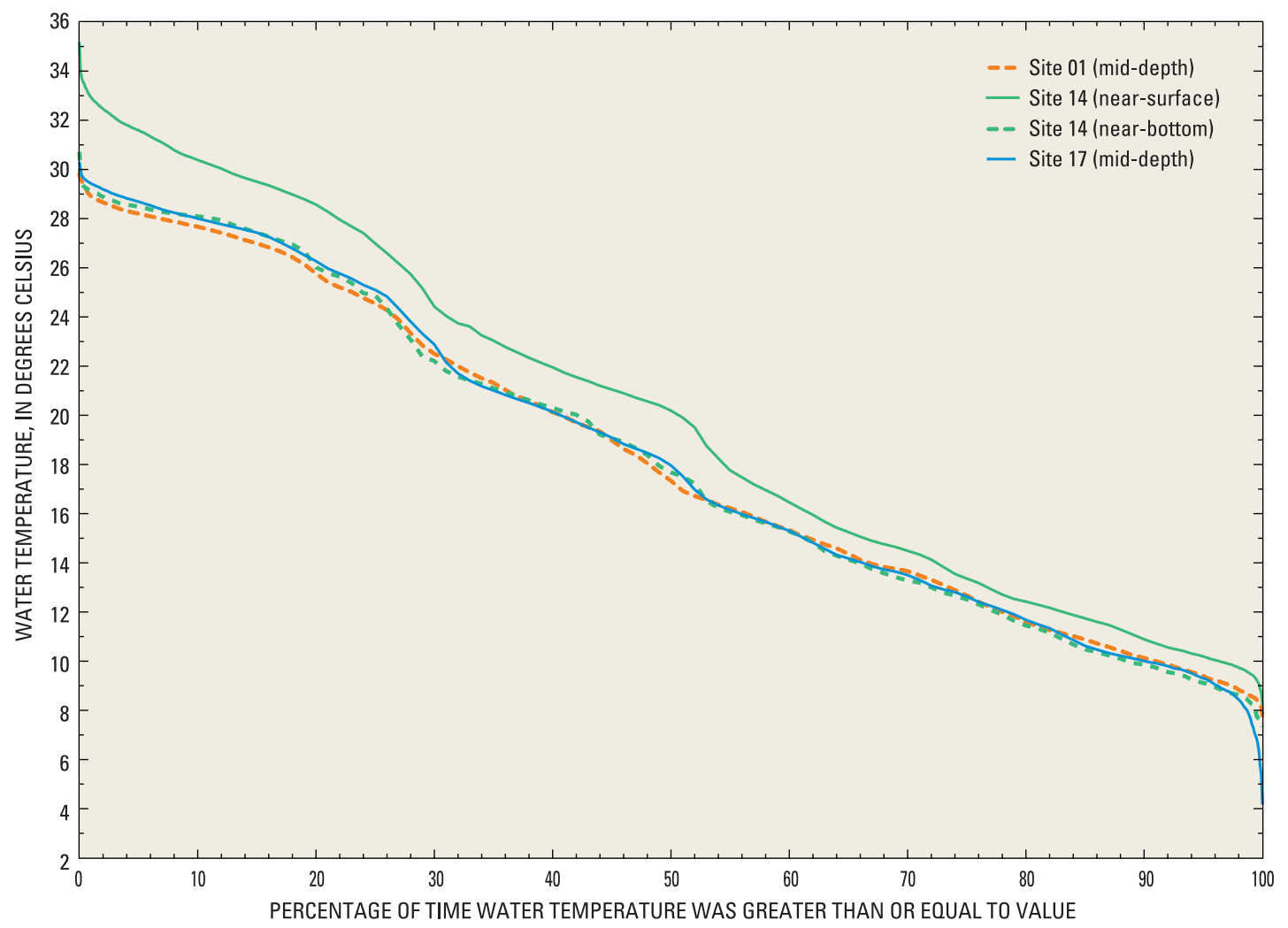

Figure 9. Water temperature durations for Mountain Island Lake continuous water-quality monitoring sites, September 1, 1996-August 31, 1997.

distinct decrease of several degrees for about 30 minutes. This decrease in water temperature at site 01 is the result of an initial pulse of cooler bottom waters from Lake Norman - water located between the skimmer weir and Cowans Ford Dam-following a period of no flow. As discharge through the dam continued, warmer surface waters were pulled over the skimmer weir and through the dam turbines.

Accordingly, water temperature at site 01 typically increased, as illustrated in data from site 01 for July 15-19, 1997 (fig. 10). During the winter, when water temperatures in Lake Norman were distributed more uniformly, temperature changes at site 01 in response to discharge through Cowans Ford Dam were less evident.

At site 14, about $2 \mathrm{~km}$ upstream from Mountain Island Dam and $0.5 \mathrm{~km}$ downstream from the heated Riverbend Steam Station discharge (fig. 8), two waterquality probes were deployed-one about $2 \mathrm{~m}$ below average water surface (near surface) and one about $2.5 \mathrm{~m}$ above reservoir bottom (near bottom). Water temperatures recorded during the study at site 14 ranged from 8.2 to $35.2{ }^{\circ} \mathrm{C}$ near the surface and from
7.3 to $30.7^{\circ} \mathrm{C}$ near the bottom (Sarver and Steiner, 1998). From September 1996 to August 1997, median near-surface water temperature was $20.2^{\circ} \mathrm{C}$ (fig. 9). Median water temperature at site 14 near bottom $\left(17.7^{\circ} \mathrm{C}\right)$ was similar to that at site $01\left(17.3^{\circ} \mathrm{C}\right)$. In addition, distributions and the duration curve of water temperature at site 14 near the bottom were nearly identical to those at site 01 (fig. 9). Daily and monthly near-surface water temperatures at site 14 were consistently higher than near-bottom water temperatures. The maximum difference between nearsurface and near-bottom water temperature was $7.8^{\circ} \mathrm{C}$, with a median difference of $1.5^{\circ} \mathrm{C}$. Differences between site 14 near-surface and near-bottom water temperatures typically were greater during warm weather months than during cool weather months.

Because of the relatively shallow lake depth and the magnitude of inflow from Cowans Ford Dam, Mountain Island Lake appeared to be well mixed thermally from the headwaters to the vicinity of site 06 (fig. 11). Top-to-bottom water temperature differences at site 01 were always less than $0.8^{\circ} \mathrm{C}$ (based on 23 sets of measurements). At sites 02, 03, 04, and 06, top-to- 

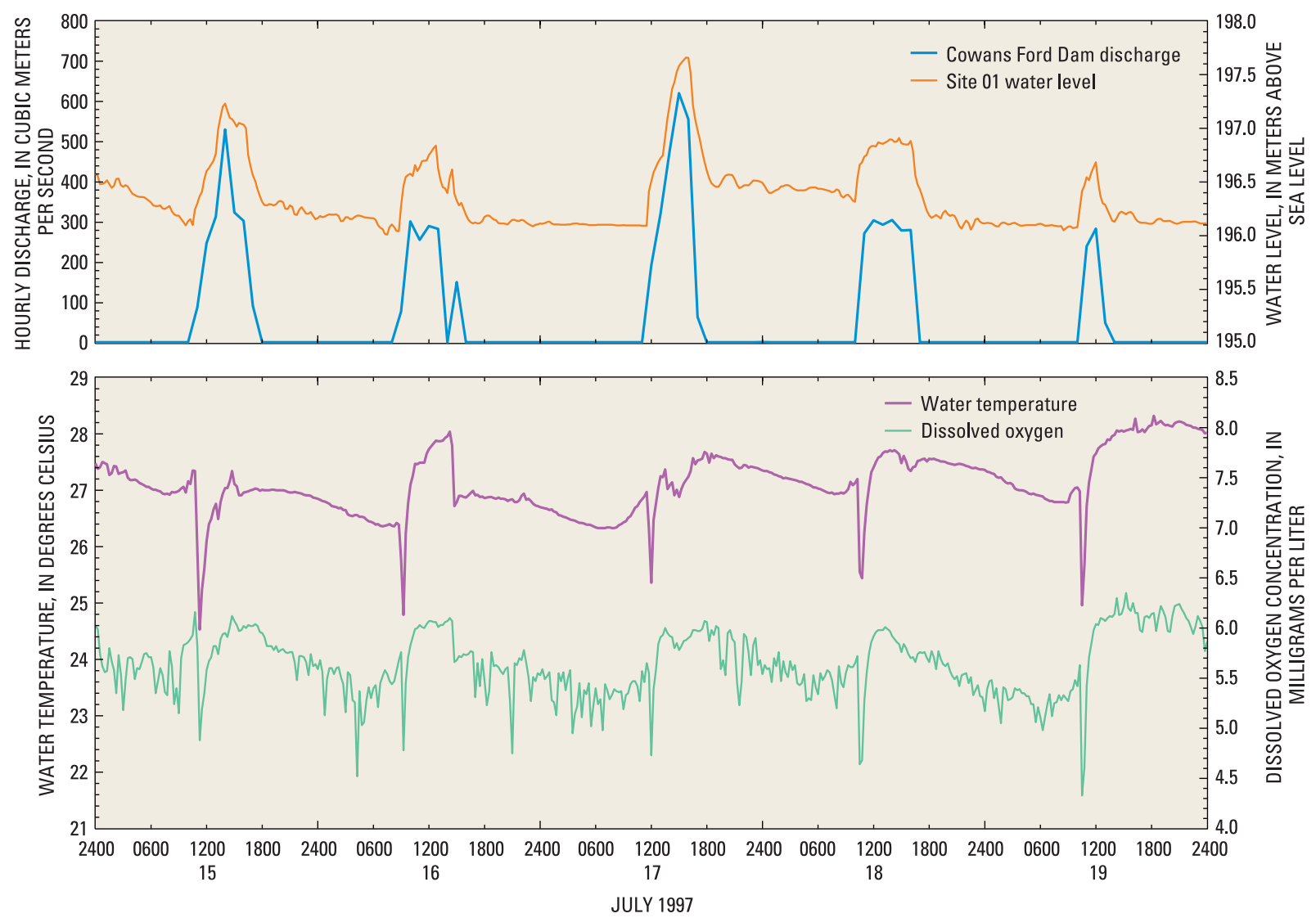

Figure 10. Discharge from Cowans Ford Dam and water level, water temperature, and dissolved-oxygen concentration at site 01, July 15-19, 1997.

bottom water-temperature differences never exceeded $2.0{ }^{\circ} \mathrm{C}$. Downstream from site 06, Mountain Island Lake stratified weakly during the fall of 1996 and summer of 1997 (fig. 11). Natural stratification that might have occurred downstream from site 12, however, was masked by discharge of condenser cooling water from Riverbend Steam Station into Mountain Island Lake about $0.5 \mathrm{~km}$ upstream from site 14 .

Riverbend Steam Station was in operation 83 percent of the days from September 1996 to August 1997. The station typically operated for 15 hours and discharged an average of 1.2 million $\mathrm{m}^{3}$ of water into Mountain Island Lake per day of operation. According to Duke Power records, the maximum temperature increase between water withdrawn near site 04 and water discharged into Mountain Island Lake upstream from site 14 was $13.1^{\circ} \mathrm{C}$ during September 1996August 1997. Median water-temperature increase between withdrawal and discharge was $6.3{ }^{\circ} \mathrm{C}$, with 75 percent of water-temperature increases ranging between 3.8 and $8.9^{\circ} \mathrm{C}$. Temperature differences generally were slightly greater in the fall and winter than in the spring and summer and did not seem to be related strongly to the volume of discharge from the steam station.

The effects of thermal releases from Riverbend Steam Station are evident in temperature distributions for Mountain Island Lake (fig. 11). For example, during December 17-18, 1996 (fig. 11A), thermal stratification was present in the upper $5 \mathrm{~m}$ of the water column between site 12 and Mountain Island Dam. Upstream, Mountain Island Lake was well mixed thermally and more representative of typical winter conditions, as discussed in Bales and Giorgino (1998). Average flow from Cowans Ford Dam during these 2 days was $180 \mathrm{~m}^{3} / \mathrm{s}$. The lake also was well mixed near Mountain Island Dam at depths below $5 \mathrm{~m}$. During December 17-18, 1996, Riverbend Steam Station discharged a total of 1.9 million $\mathrm{m}^{3}$ of water into the lake, with an average temperature increase of $11.8^{\circ} \mathrm{C}$ between withdrawal and discharge (table 4). Note that with a withdrawal temperature of $12.2^{\circ} \mathrm{C}$ (site 04 , fig. 11A), the mean discharge temperature would be 

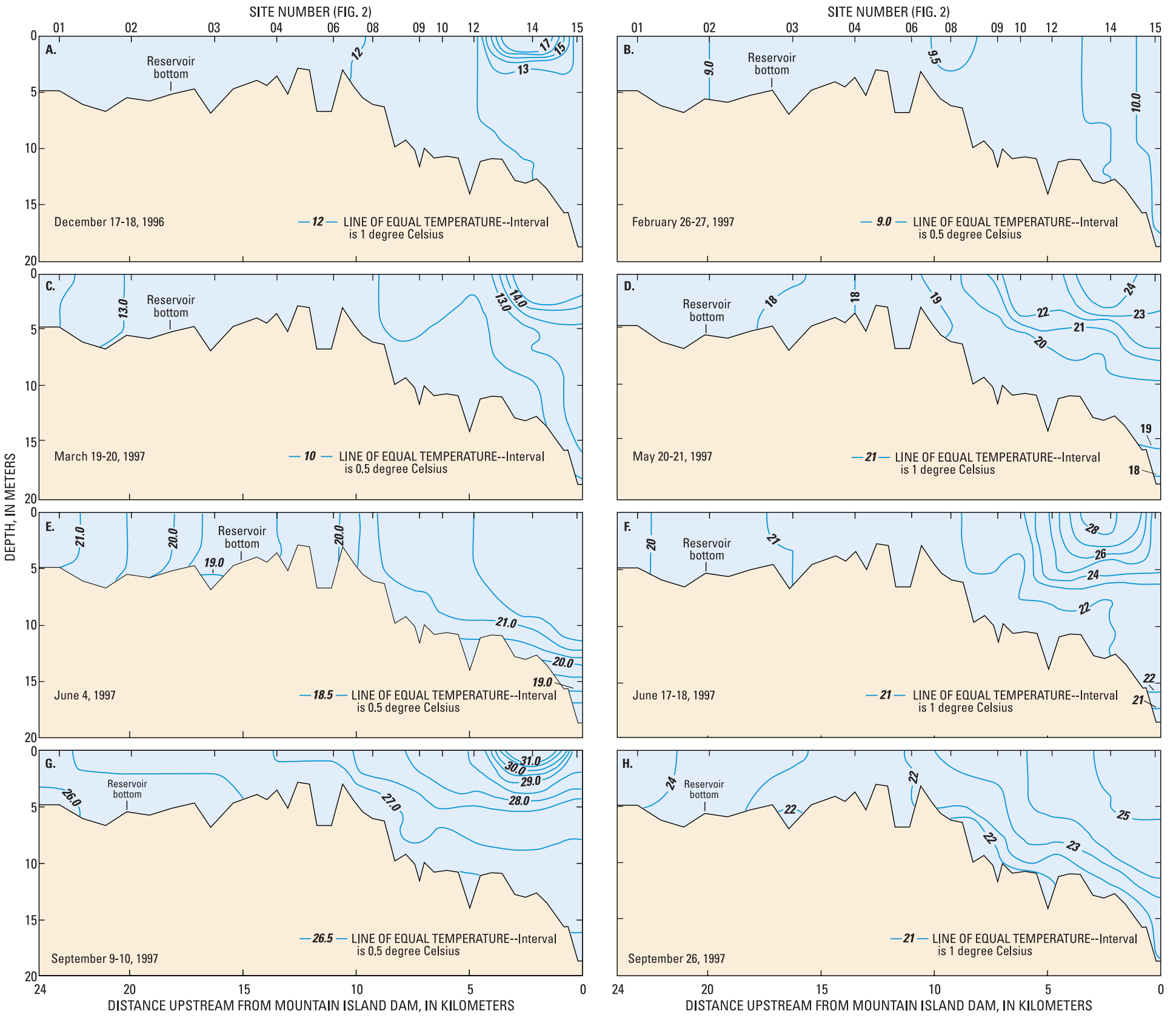

Figure 11. Distribution of water temperature in Mountain Island Lake for selected days during the study period. 
Table 4. Riverbend Steam Station cooling water discharge and water temperature data for dates on which vertical profiles of water temperature were measured in Mountain Island Lake $\left[\mathrm{m}^{3}\right.$, cubic meter; ${ }^{\circ} \mathrm{C}$, degree Celsius; - , no data. Shaded rows correspond to vertical profiles of water temperature shown in figure 11]

\begin{tabular}{|c|c|c|c|c|}
\hline $\begin{array}{l}\text { Vertical profile } \\
\text { measurement } \\
\text { date }\end{array}$ & $\begin{array}{c}\text { Discharge } \\
\left(\text { million } \mathbf{m}^{3}\right)\end{array}$ & $\begin{array}{c}\text { Inlet } \\
\text { water } \\
\text { temperature } \\
\left({ }^{\circ} \mathbf{C}\right)\end{array}$ & $\begin{array}{c}\text { Outlet } \\
\text { water } \\
\text { temperature } \\
\left({ }^{\circ} \mathrm{C}\right)\end{array}$ & $\begin{array}{l}\text { Difference in } \\
\text { water } \\
\text { temperature } \\
\left({ }^{\circ} \mathrm{C}\right)\end{array}$ \\
\hline 5-28-96 & 1.57 & 23.5 & 25.7 & 2.2 \\
\hline $5-29-96$ & 1.57 & 23.5 & 25.8 & 2.3 \\
\hline $5-30-96$ & 1.07 & 22.6 & 25.8 & 3.2 \\
\hline $6-11-96$ & 1.53 & 23.2 & 28.2 & 5.0 \\
\hline $6-12-96$ & 1.57 & 23.9 & 28.7 & 4.8 \\
\hline $6-25-96$ & 1.18 & 27.1 & 32.1 & 5.0 \\
\hline $6-26-96$ & 1.34 & 27.6 & 32.1 & 4.5 \\
\hline $7-10-96$ & 1.57 & 27.3 & 33.3 & 5.9 \\
\hline $7-11-96$ & 1.57 & 27.0 & 33.2 & 6.2 \\
\hline $7-24-96$ & 1.57 & 28.2 & 33.4 & 5.3 \\
\hline $7-25-96$ & 1.57 & 28.4 & 33.5 & 5.1 \\
\hline $8-7-96$ & 1.57 & 28.5 & 33.8 & 5.3 \\
\hline $8-8-96$ & 1.57 & 28.5 & 34.0 & 5.5 \\
\hline $9-30-96$ & 1.57 & 22.9 & 31.4 & 8.6 \\
\hline $10-22-96$ & .91 & 19.4 & 26.6 & 7.2 \\
\hline $10-23-96$ & 1.57 & 19.5 & 26.5 & 7.0 \\
\hline $11-19-96$ & .17 & 15.4 & 23.6 & 8.2 \\
\hline $11-20-96$ & .53 & 15.0 & 23.4 & 8.4 \\
\hline $12-17-96$ & .84 & 12.8 & 24.7 & 11.9 \\
\hline $12-18-96$ & 1.07 & 11.5 & 23.1 & 11.6 \\
\hline $2-26-97$ & .25 & 9.4 & 17.4 & 7.9 \\
\hline $2-27-97$ & .25 & 9.6 & 16.8 & 7.2 \\
\hline $3-19-97$ & .42 & 12.1 & 17.8 & 5.8 \\
\hline $3-20-97$ & .91 & 13.3 & 17.8 & 4.6 \\
\hline $4-3-97$ & .11 & 14.1 & 14.2 & .1 \\
\hline $4-30-97$ & 1.20 & 17.6 & 23.7 & 6.1 \\
\hline $5-1-97$ & 1.55 & 16.8 & 22.2 & 5.3 \\
\hline $5-20-97$ & 1.15 & 19.1 & 25.6 & 6.4 \\
\hline $5-21-97$ & 1.27 & 19.4 & 24.8 & 5.4 \\
\hline $6-4-97$ & 0 & - & - & - \\
\hline $6-17-97$ & 1.57 & 21.3 & 26.7 & 5.4 \\
\hline $6-18-97$ & 1.57 & 20.2 & 27.8 & 7.6 \\
\hline $6-30-97$ & 1.45 & 25.0 & 29.4 & 4.4 \\
\hline $7-17-97$ & 1.57 & 26.4 & 30.8 & 4.3 \\
\hline $7-30-97$ & 1.32 & 28.4 & 32.8 & 4.4 \\
\hline $7-31-97$ & .33 & 27.3 & 31.6 & 4.3 \\
\hline $8-21-97$ & 1.88 & 28.8 & 34.1 & 5.3 \\
\hline $9-9-97$ & 1.57 & 27.0 & 33.9 & 6.9 \\
\hline $9-10-97$ & 1.57 & 26.4 & 30.4 & 4.0 \\
\hline $9-26-97$ & 0 & - & - & - \\
\hline
\end{tabular}


about $24{ }^{\circ} \mathrm{C}$. Yet the highest temperature measured at site 14 near the center of the lake was $17.2^{\circ} \mathrm{C}$ (site 14 , fig. 11A). Therefore, substantial mixing of the effluent and the lake water and cooling evidently occurred between the cooling water discharge and site 14-a distance of less than $1 \mathrm{~km}$. During February 26-27, 1997 (fig. 11B), the Riverbend Steam Station was operating, but with very low withdrawals and outflows and little stratification in the lake. Flows from Cowans Ford Dam on these 2 days averaged $162 \mathrm{~m}^{3} / \mathrm{s}$, very similar to conditions during December 17-18, 1996. Riverbend Steam Station did not operate on June 4, 1997 (fig. 11E), or September 26, 1997 (fig. 11H), and weak natural stratification typical of summer and early fall conditions in Piedmont reservoirs (Giorgino and Bales, 1997; Bales and Giorgino, 1998) was present downstream from site 08. Average flow from Cowans Ford Dam on these 2 days was about $20 \mathrm{~m}^{3} / \mathrm{s}$. Varying degrees of natural stratification, influenced to some extent near site 14 by the Riverbend Steam Station discharge, were present at other times during the study period (fig. 11; table 4).

In summary, because of the magnitude of inflows from Cowans Ford Dam, relatively shallow depths, and short theoretical retention times ( $<1-12$ days), Mountain Island Lake is well mixed thermally throughout much of its length. The lake exhibits weak stratification downstream from near site 06 during late spring, summer, and early fall in response to warm air temperatures. This weak natural stratification, however, seems to be overwhelmed by the effect of thermal releases from Riverbend Steam Station into Mountain Island Lake about $0.5 \mathrm{~km}$ upstream from site 14.

At site 17, located on the Catawba River downstream from Mountain Island Dam (fig. 2), water temperature ranged from 4.2 to $30.3{ }^{\circ} \mathrm{C}$ during the study (Sarver and Steiner, 1998). From September 1996 to August 1997, the median water temperature at site 17 was $18.0^{\circ} \mathrm{C}$, with 70 percent of the values ranging between 10.6 and $27.4{ }^{\circ} \mathrm{C}$ (fig. 9). Water temperature distributions and the duration curve for site 17 are nearly identical to those of site 01 and site 14 near bottom.

\section{Dissolved-Oxygen Concentration}

Dissolved-oxygen concentrations in Mountain Island Lake were influenced by DO concentrations in water released to the headwaters from Lake Norman and by the weak thermal stratification in Mountain
Island Lake. At site 01, DO concentrations ranged from 3.2 to $11.3 \mathrm{mg} / \mathrm{L}$ (Sarver and Steiner, 1998). DO concentrations generally were lower in summer and early fall and higher in winter. During September 1996-August 1997, the median DO concentration at site 01 was $7.7 \mathrm{mg} / \mathrm{L}$ (fig. 12). North Carolina ambient water-quality standards require a daily average DO concentration of at least $5.0 \mathrm{mg} / \mathrm{L}$ and a minimum instantaneous concentration of $4.0 \mathrm{mg} / \mathrm{L}$ (North Carolina Department of Environment, Health, and Natural Resources, 1997). Daily mean DO concentrations of less than $5.0 \mathrm{mg} / \mathrm{L}$ occurred at site 01 for 21 days during the 12-month period from September 1996 to August 1997 and for 34 days during the entire 18-month study period (April 1996September 1997). Daily mean DO concentrations of less than $5.0 \mathrm{mg} / \mathrm{L}$ occurred only during the months of July, August, or September. The lowest daily mean DO concentration at site 01 was $4.5 \mathrm{mg} / \mathrm{L}$. Only 0.1 percent of the DO concentrations at site 01 were less than $4 \mathrm{mg} / \mathrm{L}$ (fig. 12). DO concentrations at site 01 likely reflect DO concentrations in the upper 6-11 $\mathrm{m}$ of Lake Norman - the zone of water discharged through Cowans Ford Dam. Vertical profile measurements made in mid-August 1997 at a site directly upstream from Cowans Ford Dam in Lake Norman indicated that DO concentrations in the upper $11 \mathrm{~m}$ ranged from 0.5 to $7.2 \mathrm{mg} / \mathrm{L}$ (D. Owen, North Carolina Division of Water Quality, written commun., January 2000).

During the summer at site 01 , the DO response to the intermittent discharge from Cowans Ford Dam was similar to the water temperature response. The initial release of water from Cowans Ford Dam following a period of no releases resulted in a decrease in DO concentration at site 01 of about $1 \mathrm{mg} / \mathrm{L}$ in conjunction with a water-temperature decrease of several degrees (fig. 10), reflecting the initial release of cooler, less oxygenated bottom water from Lake Norman (water located between the dam and the skimmer weir). Within 1-3 hours, the DO concentration typically recovered to predischarge conditions or became slightly higher as warmer, more oxygenated surface waters were pulled over the skimmer weir with continued discharge through the dam. During the winter when Lake Norman was less stratified, these short-term changes in response to discharge through Cowans Ford Dam were not evident.

Continuously measured DO concentrations at site 14 ranged from 4.3 to $11.4 \mathrm{mg} / \mathrm{L}$ for the nearsurface sensor and from 2.1 to $10.3 \mathrm{mg} / \mathrm{L}$ for the near- 


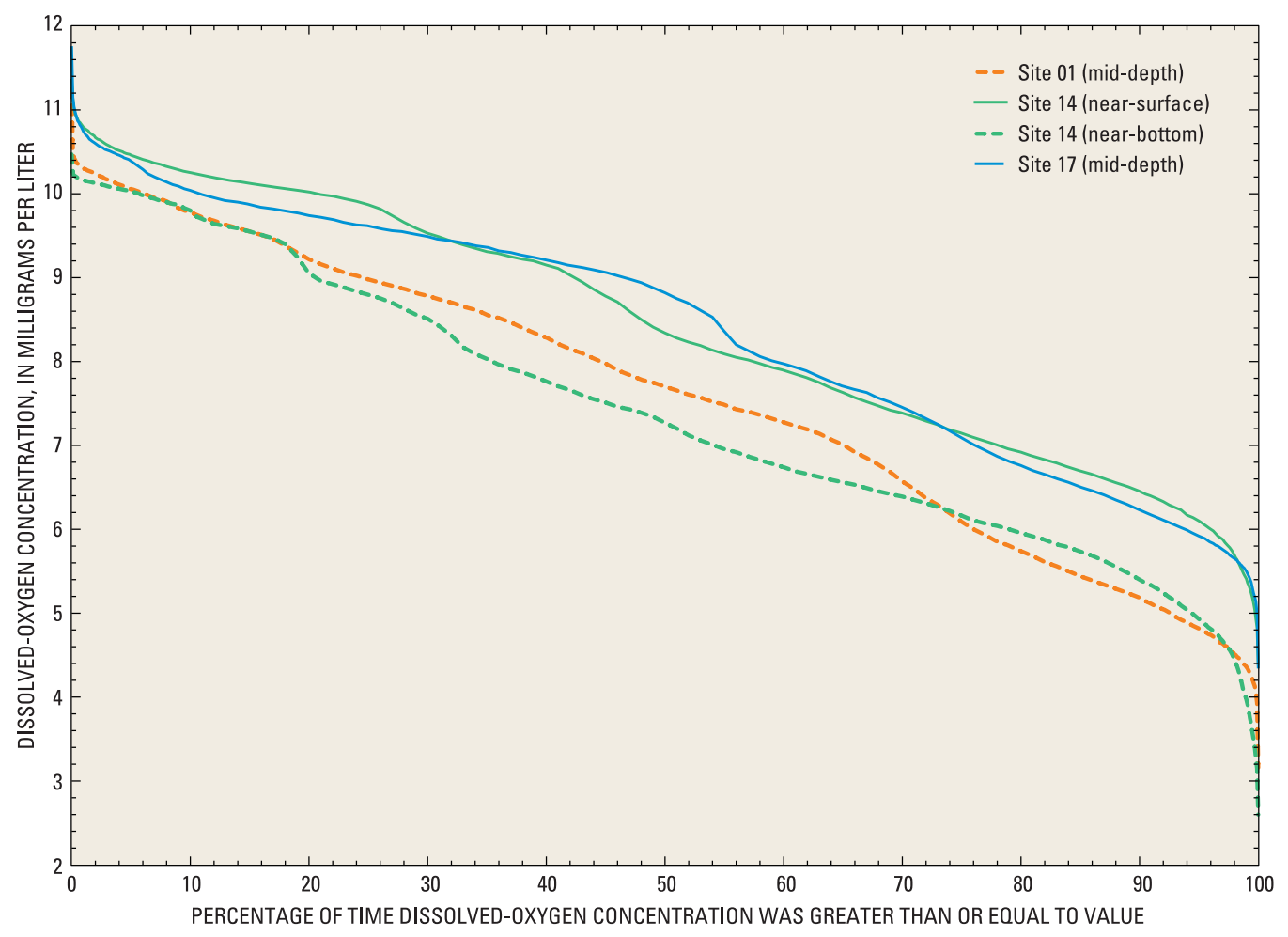

Figure 12. Dissolved-oxygen concentration durations for Mountain Island Lake continuous water-quality monitoring sites, September 1, 1996-August 31, 1997.

bottom sensor (Sarver and Steiner, 1998). For the period September 1996-August 1997, median nearsurface DO was $8.3 \mathrm{mg} / \mathrm{L}$, while median near-bottom DO was $7.3 \mathrm{mg} / \mathrm{L}$ (fig. 12). The maximum difference between near-surface and near-bottom DO

concentration at site 14 was $4.1 \mathrm{mg} / \mathrm{L}$, with a median difference of $0.4 \mathrm{mg} / \mathrm{L}$. Eighty percent of DO concentration differences between near-surface and near-bottom measurements were less than $1.0 \mathrm{mg} / \mathrm{L}$.

No violations of State DO standards were observed at site 14 near surface during the study. For the 12-month period September 1996-August 1997, near-bottom daily mean DO concentrations were less than $5.0 \mathrm{mg} / \mathrm{L}$ for only 11 days during summer stratification in July and August 1997. Only 0.9 percent of the measured values were less than $4 \mathrm{mg} / \mathrm{L}$ (fig. 12). During the entire 18-month study, near-bottom daily mean DO concentrations at site 14 were less than the State standard for 48 days, all during the months of May, June, July, and August. Low DO concentrations in lake-bottom waters, however, are not considered violations of the State standard if caused by natural conditions (North Carolina Department of Environment, Health, and Natural Resources, 1997).
For most of the year, DO was fairly uniform throughout the upstreammost $15 \mathrm{~km}$ of the reservoir (fig. 13). In this reach, top-to-bottom DO concentration differences were always less than or equal to $1.1 \mathrm{mg} / \mathrm{L}$ during all profile measurements. DO concentrations were very nearly at 100 -percent saturation and well mixed in the water column throughout the entire mainstem of Mountain Island Lake from fall through spring (figs. 13A-D). With summer stratification, demands from hypolimnetic waters and bed sediments reduced DO concentrations at greater depths in the lacustrine zone of the mainstem, downstream from site 06. Lower DO concentrations persisted in the hypolimnion through summer and early fall (figs. 13E$\mathrm{G})$, while DO concentrations in the upper 5 to $6 \mathrm{~m}$ of the water column were at or near saturation. By late fall, DO concentrations returned to nearly saturated and well-mixed conditions throughout the reservoir (fig. 13H). Discharge from Riverbend Steam Station about $0.5 \mathrm{~km}$ upstream from site 14 did not seem to affect DO concentration. Throughout the study period, only a few occurrences of supersaturated conditions occurred in the mainstem, but the saturation levels generally were less than 110 percent. Supersaturated 

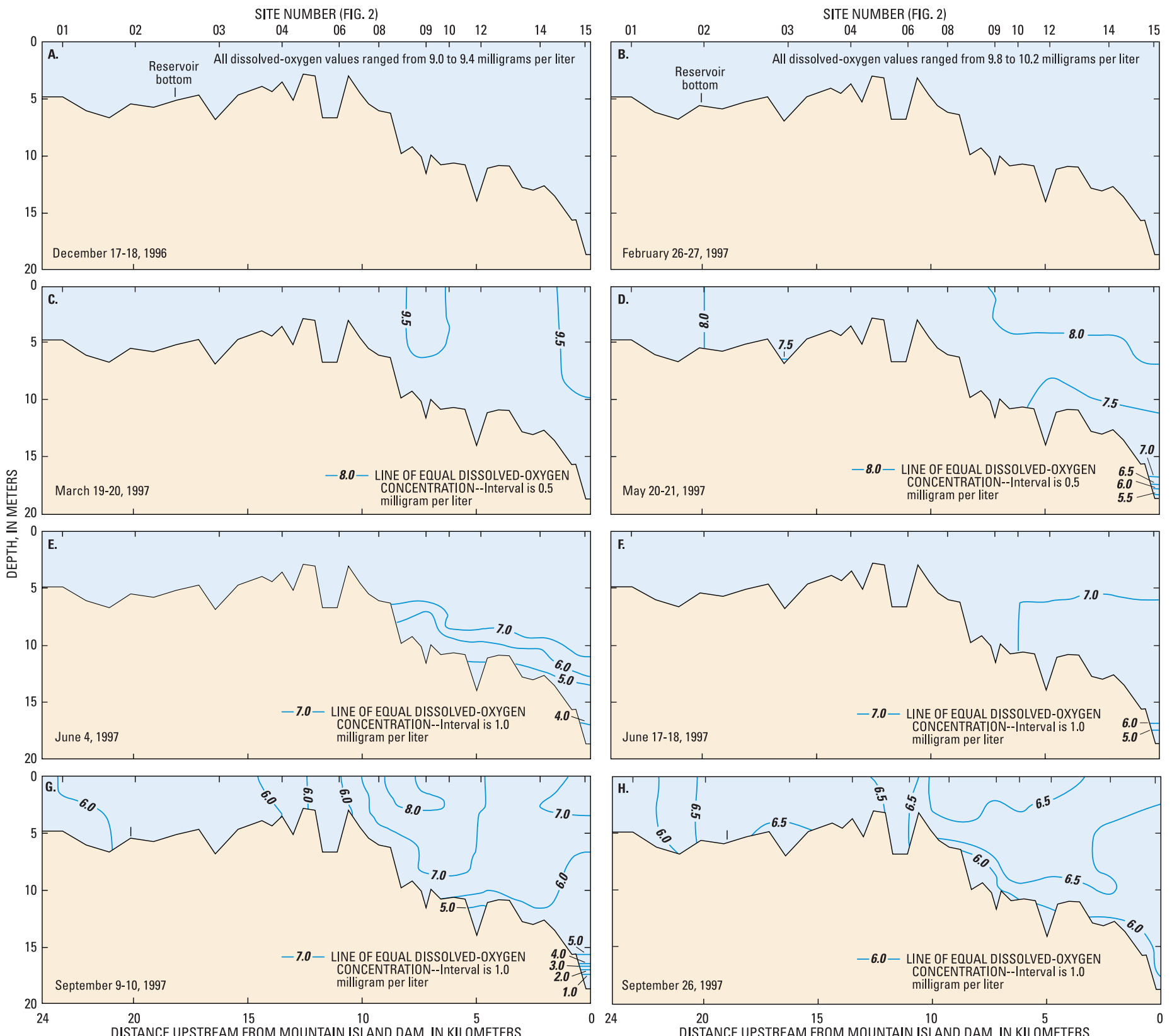

Figure 13. Distribution of dissolved-oxygen concentrations in Mountain Island Lake for selected days during the study period. 
conditions were observed, however, in 10 of the 16 vertical profiles taken in McDowell Creek cove in contrast to conditions in both the mainstem and Gar Creek cove.

Dissolved-oxygen concentration at Catawba River site 17 (fig. 2) ranged from 4.3 to $11.8 \mathrm{mg} / \mathrm{L}$ (Sarver and Steiner, 1998). During September 1996August 1997, the median DO concentration was $8.8 \mathrm{mg} / \mathrm{L}$ (fig. 12). No violations of the State DO standards were observed at site 17 during the study.

\section{Specific Conductance}

Specific conductance in Mountain Island Lake was influenced by inflow from Lake Norman and by wastewater-treatment plant discharge. The median specific conductance in the mainstem of Mountain Island Lake during September 1996-August 1997 was 57 microsiemens per centimeter $(\mu \mathrm{S} / \mathrm{cm})$ at $25^{\circ} \mathrm{C}$ at site 01 and at site 14 near surface and near bottom (fig. 14). Specific conductance measured at a site in Lake Norman directly upstream from Cowans Ford Dam ranged from 51 to $58 \mu \mathrm{S} / \mathrm{cm}$ in the discharge zone during June, July, and August 1997 (D. Owen, North Carolina Division of Water Quality, written commun., January 2000). Specific conductance was fairly consistent in the mainstem of Mountain Island Lake. During September 1996-August 1997, 98 percent of the specific conductance values ranged between 51 and $61 \mu \mathrm{S} / \mathrm{cm}$ at site 01 , between 50 and $62 \mu \mathrm{S} / \mathrm{cm}$ at site 14 near surface, and between 53 and $64 \mu \mathrm{S} / \mathrm{cm}$ at site 14 near bottom. Mountain Island Lake specific conductance values are similar to median specific conductance values ranging from 13 to $62 \mu \mathrm{S} / \mathrm{cm}$ at nine stream sites draining undeveloped forested basins in North Carolina (Caldwell, 1992). Specific conductance values of this magnitude indicate low concentrations of dissolved solids in the water.

Vertical profiles of specific conductance generally showed little vertical or longitudinal variation throughout the mainstem. Specific conductance generally differed by less than 5 to $10 \mu \mathrm{S} / \mathrm{cm}$ between and within all mainstem sites during each set of profile measurements. Specific conductance did not vary seasonally, except during July and August when specific conductance measurements in the deepest $2 \mathrm{~m}$ at site 15 (closest to Mountain Island Dam) were as much as $70 \mu \mathrm{S} / \mathrm{cm}$ higher than the rest of the mainstem. This was also the period of greatest thermal stratification in the reservoir.

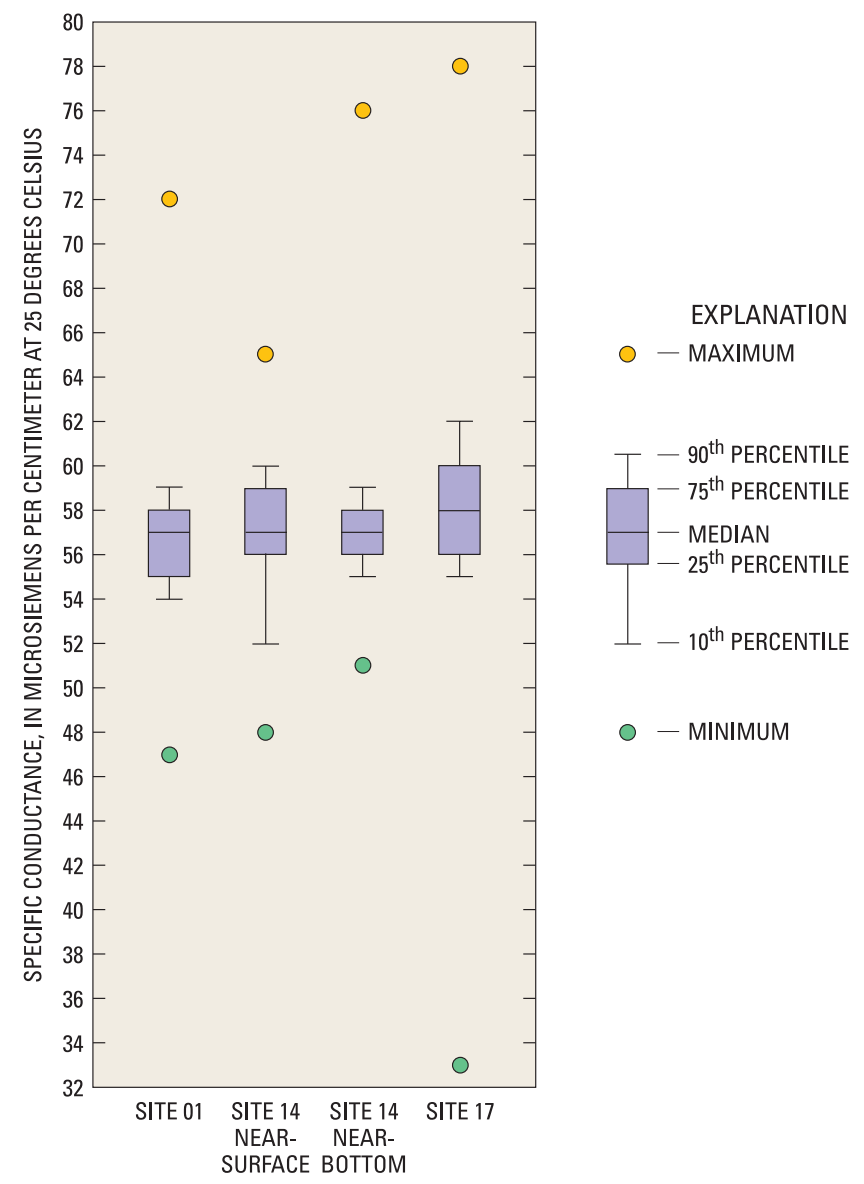

Figure 14. Distribution of specific conductance at Mountain Island Lake continuous water-quality monitoring sites, September 1, 1996-August 31, 1997.

Specific conductance values measured at site 07 (fig. 2) were higher than those measured in the mainstem of the reservoir and ranged from 52 to $194 \mu \mathrm{S} / \mathrm{cm}$, with a median of $81 \mu \mathrm{S} / \mathrm{cm}$. Site 07 is located in McDowell Creek cove, about $1.5 \mathrm{~km}$ downstream from the McDowell Creek WWTP effluent outfall. Mean depth at site 07 was $3.2 \mathrm{~m}$ during the 23 sets of profile measurements, and specific conductance generally was higher just above the cove bottom than near the water surface. Near-bottom median specific conductance was $129 \mu \mathrm{S} / \mathrm{cm}$, whereas the median value measured $0.5 \mathrm{~m}$ below the water surface was $70 \mu \mathrm{S} / \mathrm{cm}$. The median difference between near-surface and near-bottom specific conductance at site 07 was $50 \mu \mathrm{S} / \mathrm{cm}$. McDowell Creek cove was sometimes slightly thermally stratified; top-to-bottom temperature differences ranged from 0.0 to $4.0^{\circ} \mathrm{C}$, with a median difference of $2.0^{\circ} \mathrm{C}$. Inflows to McDowell 
Creek cove from McDowell Creek and McDowell Creek WWTP tended to be cooler, however, than water in the cove, particularly in late spring and summer. Higher specific conductance values in bottom waters of McDowell Creek cove likely resulted from slightly cooler, higher conductivity inflows plunging beneath the water surface in the cove. During this study, McDowell Creek WWTP discharged an average of $0.100 \mathrm{~m}^{3} / \mathrm{s}$ into the cove, with a median specific conductance of $457 \mu \mathrm{S} / \mathrm{cm}$ (M.E. Lieber, North Carolina Division of Water Quality, written commun., September 1998). Average discharge at McDowell Creek site 44 (fig. 2), located upstream from the WWTP, was $0.84 \mathrm{~m}^{3} / \mathrm{s}$, with a median specific conductance of $146 \mu \mathrm{S} / \mathrm{cm}$ (Robinson, Hazell, and Garrett, 1998).

Specific conductance values in two other cove sites on Mountain Island Lake were similar to those in the mainstem. Specific conductance values in Gar Creek cove (site 11, fig. 2) ranged from 45 to $66 \mu \mathrm{S} / \mathrm{cm}$ (median $55 \mu \mathrm{S} / \mathrm{cm}$ ), and values at site 13 (fig. 2) ranged from 49 to $62 \mu \mathrm{S} / \mathrm{cm}$ (median $57 \mu \mathrm{S} / \mathrm{cm}$ ). Top-tobottom differences in specific conductance were negligible at sites 11 and 13. Median specific conductance recorded at site 17 (fig. 2) was $58 \mu \mathrm{S} / \mathrm{cm}$ during September 1996-August 1997 (fig. 14), with 92 percent of the values ranging between 53 and $64 \mu \mathrm{S} / \mathrm{cm}$.

pH

During the study, $\mathrm{pH}$ in the mainstem of Mountain Island Lake ranged from 6.2 to 8.2 standard units, and median values determined from the profiles at all mainstem sites ranged between 6.7 and 6.9. Measurements of $\mathrm{pH}$ were fairly consistent throughout the mainstem, with little vertical or longitudinal variation. Most $\mathrm{pH}$ differences observed at sites 01,02 , 03, 04, and 06 were less than 0.3. During winter and spring, $\mathrm{pH}$ was fairly uniform throughout the entire mainstem of the reservoir, with maximum $\mathrm{pH}$ differences of 0.5 among the sites. In the summer, $\mathrm{pH}$ was slightly elevated at greater depths near Mountain Island Dam; however, the maximum $\mathrm{pH}$ difference measured at the mainstem sites during the summer was 1.9. At all sites, $\mathrm{pH}$ measurements were within the range (6.0-9.0) recommended by the North Carolina Department of Environment, Health, and Natural Resources (1997) to protect aquatic life and for general water use.

\section{Chemical and Biological Constituents}

Water-chemistry samples were collected 17 times from May 1996 to September 1997 at eight sites in the study area (table 2). Three sites $(04,09$, and 14) are located in the mainstem, and three sites $(07,11$, and 13) are located in coves of Mountain Island Lake (fig. 2). Sites 01 and 17 are riverine in nature and represent inflows from Cowans Ford Dam at Lake Norman and outflows from Mountain Island Dam, respectively (fig. 2).

Samples were analyzed for a suite of waterquality constituents, including fecal coliform bacteria, total and volatile suspended solids, nutrients, chlorophyll $a$, and total organic carbon. Samplecollection methods, laboratory analytical methods, and complete listings of water-quality data were reported previously (Sarver and Steiner, 1998). In this report, results for selected water-quality constituents are interpreted to characterize current conditions in Mountain Island Lake in reference to North Carolina water-quality standards and to depict spatial and seasonal variations. Results from the Mountain Island Lake study area are compared to results from recent studies of other reservoirs in the Catawba River Basin.

Constituent concentrations were analyzed for spatial (site-to-site) differences and for seasonality. Boxplots are presented to illustrate the distribution of observations at each site and to provide a mechanism for visualizing differences among sites. Both parametric and nonparametric statistical methods were used to interpret the water-quality data, depending on characteristics of the data set. One-way analysis of variance and the nonparametric Kruskal-Wallis procedure, followed by appropriate multiplecomparison tests, were used to test for spatial differences. Plots of constituent concentrations with time were used to examine seasonality in the data. For all procedures, statistical significance was defined as a $p$-value or alpha less than or equal to 0.05 .

\section{Nitrogen and Phosphorus}

Elevated concentrations of nitrogen and phosphorus contribute to water-quality degradation by accelerating eutrophication (undesirably high levels of algal productivity and shifts in community structure) in lakes, reservoirs, and coastal estuaries. The U.S. Environmental Protection Agency has advised States to address nutrient regulation in their water-quality rules by the year 2003 (D.M. Reid, North Carolina Division 
of Water Quality, oral commun., August 1999). Currently (2001), North Carolina water-quality standards for nutrients have been promulgated only for $\mathrm{NO}_{3}$ in water supplies (North Carolina Department of Environment, Health, and Natural Resources, 1997). It is widely accepted, however, that elevated concentrations of nitrogen and phosphorus contribute to water-quality degradation by accelerating eutrophication in lakes and reservoirs. Lake productivities generally correspond to nitrogen and phosphorus levels (table 5). Eutrophic and hypereutrophic lakes generally exhibit nuisance growths of algae and other undesirable symptoms of overenrichment. Concentrations of $\mathrm{NO}_{3}$ greater than $10 \mathrm{mg} / \mathrm{L}$ are considered a public health risk when ingested, especially by small children and the elderly, because high concentrations have been linked to methemoglobinemia, commonly known as blue-baby syndrome. Excessive concentrations of $\mathrm{NO}_{3}$ usually are associated with anthropogenic sources, such as municipal wastes and urban and agricultural runoff.

Table 5. General relation of lake productivity to average concentrations of inorganic nitrogen and total phosphorus (modified from Wetzel, 1983)

[mg/L, milligram per liter; <, less than; >, greater than]

\begin{tabular}{lcc}
\hline $\begin{array}{c}\text { Level of lake } \\
\text { productivity }\end{array}$ & $\begin{array}{c}\text { Inorganic } \\
\text { nitrogen } \\
(\mathbf{m g} / \mathbf{L})\end{array}$ & $\begin{array}{c}\text { Total } \\
\text { phosphorus } \\
(\mathbf{m g} / \mathbf{L})\end{array}$ \\
\hline \hline Ultra-oligotrophic & $<0.20$ & $<0.005$ \\
Oligo-mesotrophic & $0.20-0.40$ & $0.005-0.01$ \\
Meso-eutrophic & $0.30-0.65$ & $0.01-0.03$ \\
Eutrophic & $0.5-1.5$ & $0.03-0.10$ \\
Hypereutrophic & $>1.5$ & $>0.10$ \\
\hline
\end{tabular}

Forms of nitrogen and phosphorus analyzed during this study include dissolved nitrite plus nitrate, dissolved ammonia, total ammonia plus organic nitrogen, TP, and dissolved orthophosphorus. Concentrations of nitrogen forms are reported in equivalent units of elemental nitrogen, and phosphorus forms are reported in equivalent units of elemental phosphorus.

\section{Nitrogen}

Nitrogen occurs in numerous forms and oxidation states in the environment. Nitrite plus nitrate (hereafter referred to as nitrate or $\mathrm{NO}_{3}$ ) and $\mathrm{NH}_{4}$ are inorganic species of nitrogen that are readily assimilated by aquatic plants. Organic nitrogen occurs in water as dissolved amino acids and polypeptides and as living or detrital particulate matter. Sources of nitrogen to surface waters include fertilizers, animal wastes, soil leaching, atmospheric deposition, ground-water inputs, decomposition of organic matter, and biological fixation of nitrogen gas (Hem, 1970; Wetzel, 1983).

In the Mountain Island Lake study area, $\mathrm{NO}_{3}$ was highest at site 07 (McDowell Creek cove), where concentrations ranged from 0.110 to $2.77 \mathrm{mg} / \mathrm{L}$ with medians of $0.470 \mathrm{mg} / \mathrm{L}$ for near-surface samples and $0.650 \mathrm{mg} / \mathrm{L}$ for near-bottom samples (fig. 15A; table 6). These results are similar to concentrations measured in 1993-94 at three sites in McDowell Creek cove, when concentrations ranged from 0.08 to $2.30 \mathrm{mg} / \mathrm{L}$ (North Carolina Department of Environment, Health, and Natural Resources, 1996). Median $\mathrm{NO}_{3}$ concentrations in stormwater samples collected from McDowell Creek (Sarver and others, 1999) site $34(0.380 \mathrm{mg} / \mathrm{L})$ and site $44(0.570 \mathrm{mg} / \mathrm{L})$ — both of which are upstream from the McDowell Creek WWTP-also were similar to median $\mathrm{NO}_{3}$ concentrations at site 07 . In comparison, $\mathrm{NO}_{3}$ concentrations at all other sites in the study area ranged from $<0.005$ to $0.348 \mathrm{mg} / \mathrm{L}$, with medians less than or equal to $0.210 \mathrm{mg} / \mathrm{L}$ (tables 6-8). Overall, the lowest $\mathrm{NO}_{3}$ concentrations were measured in the Gar Creek cove of Mountain Island Lake (site 11). No samples collected during this study exceeded the North Carolina water-quality standard for $\mathrm{NO}_{3}$ of $10 \mathrm{mg} / \mathrm{L}$.

With the exception of site 07 , ranges and median concentrations of $\mathrm{NO}_{3}$ at sites in the Mountain Island Lake study area were similar to levels observed during water-quality investigations of Rhodhiss Lake and Lake Hickory in 1993-94 (Giorgino and Bales, 1997; Bales and Giorgino, 1998). Median $\mathrm{NO}_{3}$ concentrations at six sites (three in Rhodhiss Lake and three in Lake Hickory) during these investigations ranged from 0.065 to $0.256 \mathrm{mg} / \mathrm{L}$. Rhodhiss Lake and Lake Hickory are mainstem reservoirs located on the Catawba River upstream from Mountain Island Lake.

All sites except site 07 had similar concentrations of $\mathrm{NO}_{3}$ during individual sampling visits, and differences between near-surface and near-bottom samples were minimal (fig. 15A). These results indicate that $\mathrm{NO}_{3}$ concentrations in the inflow from Lake Norman largely determined the concentrations observed throughout Mountain Island Lake except in the McDowell Creek cove. 

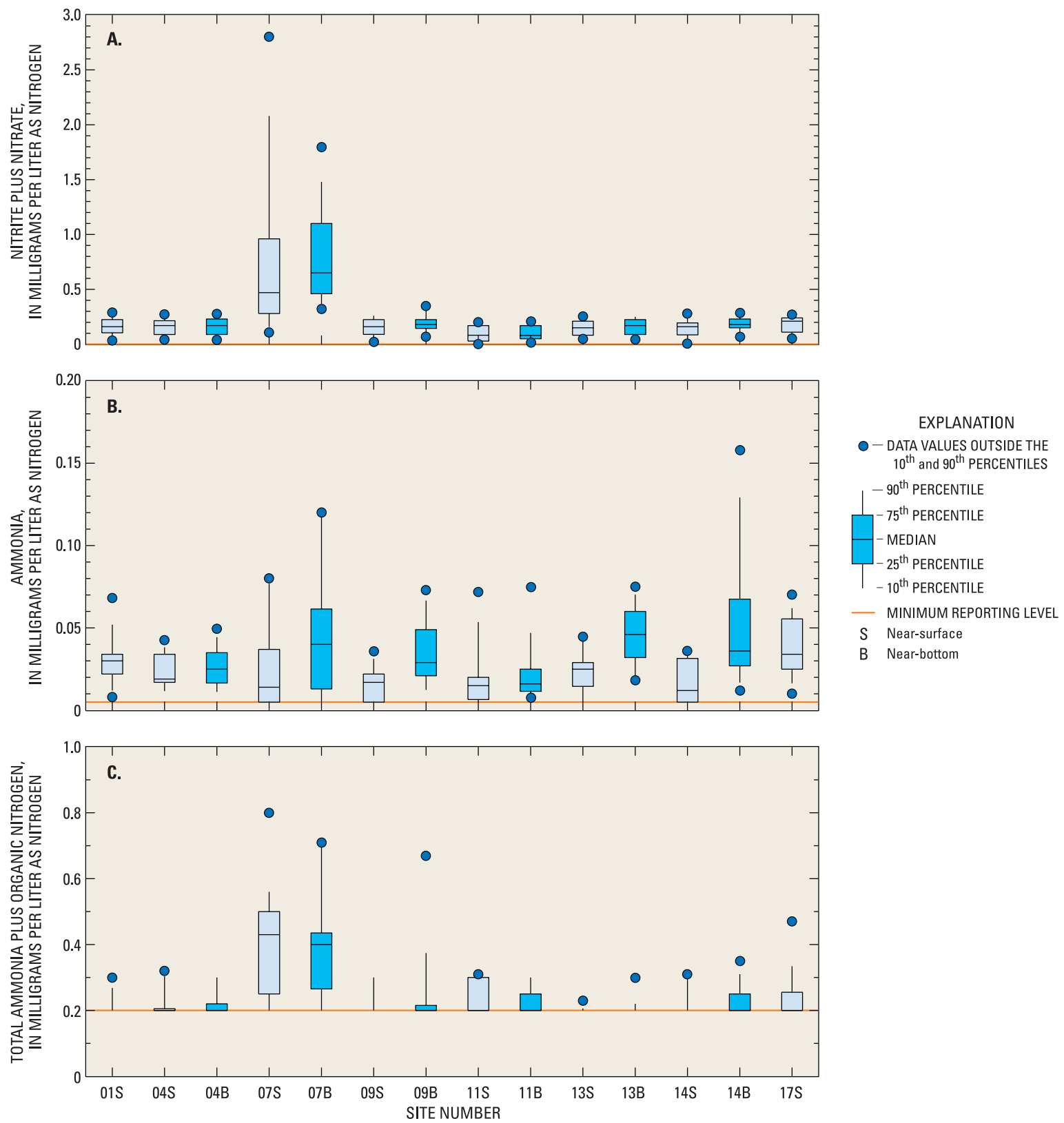

Figure 15. Distributions of concentrations of (A) nitrite plus nitrate, (B) ammonia, and (C) total ammonia plus organic nitrogen at Mountain Island Lake sites, May 1996-September 1997. 
Table 6. Statistical summary of selected water-quality properties and constituents at Mountain Island Lake cove sites 07,11 , and 13 , May 1996-September 1997

[Max, maximum; Min, minimum; Mean, arithmetic mean; Med, median; mg/L, milligram per liter; <, less than; *, value is estimated by using a log-probability regression to predict the values of data below the minimum reporting level; —, insufficient data to calculate statistic; $\mu \mathrm{g} / \mathrm{L}$, microgram per liter; cols/100 mL, colonies per 100 milliliters; $\dagger$, geometric mean]

\begin{tabular}{|c|c|c|c|c|c|c|c|c|c|c|c|c|}
\hline \multirow{2}{*}{ Property or constituent } & \multicolumn{4}{|c|}{ Site 07} & \multicolumn{4}{|c|}{ Site 11} & \multicolumn{4}{|c|}{ Site 13} \\
\hline & Max & Min & Mean & Med & Max & Min & Mean & Med & Max & Min & Mean & Med \\
\hline \multicolumn{13}{|c|}{ Near surface } \\
\hline Transparency, Secchi disk (meters) & 1.6 & 0.2 & 0.6 & 0.6 & 2.4 & 0.5 & 1.1 & 1.0 & 2.6 & 0.7 & 1.8 & 1.9 \\
\hline Solids, total suspended (mg/L) & 42 & 2 & 11 & 9 & 10 & 3 & 6 & 6 & 9 & $<1$ & $4^{*}$ & 4 \\
\hline Solids, volatile suspended (mg/L) & 10 & $<1$ & $3 *$ & 3 & 8 & $<1$ & $4^{*}$ & 4 & 7 & $<1$ & $2 *$ & 2 \\
\hline $\begin{array}{l}\text { Nitrogen, nitrite plus nitrate dissolved } \\
\quad(\mathrm{mg} / \mathrm{L} \text { as } \mathrm{N})\end{array}$ & 2.77 & .110 & .727 & .470 & .207 & $<.005$ & $.101 *$ & .083 & .248 & .047 & .150 & .150 \\
\hline $\begin{array}{l}\text { Nitrogen, ammonia dissolved } \\
\quad(\mathrm{mg} / \mathrm{L} \text { as } \mathrm{N})\end{array}$ & .080 & $<.002$ & $.025^{*}$ & .014 & .072 & $<.002$ & $.018^{*}$ & .015 & .045 & .004 & .023 & .025 \\
\hline $\begin{array}{l}\text { Nitrogen, ammonia plus organic total } \\
\quad(\mathrm{mg} / \mathrm{L} \text { as } \mathrm{N})\end{array}$ & .80 & $<.20$ & $.408^{*}$ & .43 & .31 & $<.20$ & $.244 *$ & .20 & .23 & $<.20$ & - & $<.20$ \\
\hline Phosphorus, total (mg/L as $\mathrm{P}$ ) & .300 & .016 & .086 & .061 & .029 & .007 & .017 & .016 & .083 & .005 & .014 & .009 \\
\hline $\begin{array}{l}\text { Phosphorus, orthophosphate dissolved } \\
\text { (mg/L as } \mathrm{P})\end{array}$ & .210 & $<.001$ & $.034 *$ & .009 & .002 & $<.001$ & $.001 *$ & $<.001$ & .003 & $<.001$ & $.001 *$ & $<.001$ \\
\hline $\begin{array}{l}\text { Chlorophyll } a \text { (photic-zone composite; } \\
\mu \mathrm{g} / \mathrm{L} \text { ) }\end{array}$ & 13.0 & .3 & 3.4 & 1.6 & 3.2 & .1 & 1.2 & .8 & 3.5 & $<.1$ & $.7 *$ & .6 \\
\hline Fecal coliform bacteria (cols/100 mL) & 84 & 6 & $24 \dagger$ & 24 & 48 & $<1$ & $6 \dagger$ & 6 & 90 & $<1$ & $4 \dagger$ & 5 \\
\hline \multicolumn{13}{|c|}{ Near bottom } \\
\hline Solids, total suspended (mg/L) & 108 & 8 & 21 & 14 & 13 & $<1$ & $7 *$ & 6 & 13 & $<1$ & $6^{*}$ & 5 \\
\hline Solids, volatile suspended (mg/L) & 32 & $<1$ & 6 & 3 & 13 & $<1$ & $4 *$ & 4 & 7 & $<1$ & $3 *$ & 3 \\
\hline $\begin{array}{l}\text { Nitrogen, nitrite plus nitrate dissolved } \\
\quad(\mathrm{mg} / \mathrm{L} \text { as } \mathrm{N})\end{array}$ & 1.80 & .323 & .800 & .650 & .210 & .010 & .107 & .082 & .253 & .043 & .158 & .170 \\
\hline $\begin{array}{l}\text { Nitrogen, ammonia dissolved } \\
\quad(\mathrm{mg} / \mathrm{L} \text { as } \mathrm{N})\end{array}$ & .120 & $<.002$ & $.044 *$ & .040 & .075 & .008 & .022 & .016 & .075 & .018 & .045 & .046 \\
\hline $\begin{array}{l}\text { Nitrogen, ammonia plus organic total } \\
\quad(\mathrm{mg} / \mathrm{L} \text { as } \mathrm{N})\end{array}$ & .71 & $<.20$ & $.374 *$ & .40 & .30 & $<.20$ & $.196^{*}$ & .20 & .30 & $<.20$ & $.165^{*}$ & $<.20$ \\
\hline Phosphorus, total (mg/L as $\mathrm{P}$ ) & .600 & .011 & .138 & .109 & .034 & .008 & .018 & .018 & .023 & .004 & .011 & .010 \\
\hline $\begin{array}{l}\text { Phosphorus, orthophosphate dissolved } \\
\text { (mg/L as P) }\end{array}$ & .200 & .002 & .053 & .030 & .002 & $<.001$ & $.001 *$ & $<.001$ & .003 & $<.001$ & $.001 *$ & $<.001$ \\
\hline
\end{tabular}


Table 7. Statistical summary of selected water-quality properties and constituents at Mountain Island Lake riverine sites 01 and 17, May 1996-September 1997

[Max, maximum; Min, minimum; Mean, arithmetic mean; Med, median; mg/L, milligram per liter; <, less than; *, value is estimated by using a log-probability regression to predict the values of data below the minimum reporting level; $\mu \mathrm{g} / \mathrm{L}$, microgram per liter; cols/100 $\mathrm{mL}$, colonies per $100 \mathrm{milliliters;} \dagger$, geometric mean]

\begin{tabular}{|c|c|c|c|c|c|c|c|c|}
\hline \multirow{2}{*}{ Property or constituent } & \multicolumn{4}{|c|}{ Site 01} & \multicolumn{4}{|c|}{ Site 17} \\
\hline & Max & Min & Mean & Med & Max & Min & Mean & Med \\
\hline Transparency, secchi disk (meters) & 3.4 & 1.5 & 2.2 & $\overline{2.2}$ & 2.6 & 0.3 & 1.3 & 1.1 \\
\hline Solids, total suspended (mg/L) & 8 & $<1$ & $3 *$ & 3 & 46 & 1 & 12 & 10 \\
\hline Solids, volatile suspended (mg/L) & 6 & $<1$ & $2 *$ & 2 & 7 & $<1$ & $3^{*}$ & 2 \\
\hline Nitrogen, nitrite plus nitrate dissolved ( $\mathrm{mg} / \mathrm{L}$ as $\mathrm{N})$ & .290 & .038 & .165 & .160 & .273 & .057 & .177 & .210 \\
\hline Nitrogen, ammonia dissolved (mg/L as $\mathrm{N})$ & .068 & .008 & .030 & .030 & .070 & .010 & .038 & .034 \\
\hline Phosphorus, total (mg/L as $\mathrm{P})$ & .031 & .003 & .007 & .006 & .091 & .005 & .023 & .014 \\
\hline Phosphorus, orthophosphate dissolved (mg/L as $\mathrm{P}$ ) & .004 & $<.001$ & $.001 *$ & $<.001$ & .004 & $<.001$ & $.002 *$ & .001 \\
\hline Chlorophyll $a$ (photic-zone composite; $\mu \mathrm{g} / \mathrm{L}$ ) & .9 & $<.1$ & $.4^{*}$ & .3 & 1.0 & $<.1$ & $.4 *$ & .3 \\
\hline Fecal coliform bacteria (cols $/ 100 \mathrm{~mL})$ & 39 & $<1$ & $3 \dagger$ & 2 & 130 & $<1$ & $11 \dagger$ & 9 \\
\hline
\end{tabular}

Nitrate concentrations peaked during spring and early summer months and were lowest during late summer and fall at all Mountain Island Lake sites (fig. 16). Seasonal cycles of $\mathrm{NO}_{3}$ have been observed in several other southeastern U.S. reservoirs; however, concentrations generally peak during winter and are lowest throughout the summer (Radtke, 1986; Giorgino and Bales, 1997; Bales and Giorgino, 1998). During the summer growing season in productive reservoirs, $\mathrm{NO}_{3}$ tends to be depleted rapidly from surface waters by plankton uptake and from bottom waters by denitrification (Wetzel, 1983). The primary source of water to Mountain Island Lake is Lake Norman, which is relatively unproductive (North Carolina Department of Environment and Natural Resources, 1999a). Water-quality data from a site directly upstream from Cowans Ford Dam in Lake Norman indicated that $\mathrm{NO}_{3}$ depletion occurred late in the growing season, with concentrations declining from $0.21 \mathrm{mg} / \mathrm{L}$ in mid-June to $0.04 \mathrm{mg} / \mathrm{L}$ in midAugust 1997 (D. Owen, North Carolina Division of Water Quality, written commun., September 1999). The seasonal pattern of $\mathrm{NO}_{3}$ concentrations observed in Mountain Island Lake was consistent with the pattern observed in Lake Norman during 1997.

Ammonia concentrations at the Mountain Island Lake sites ranged from $<0.002$ to $0.158 \mathrm{mg} / \mathrm{L}$ (tables 6-8). Median concentrations ranged from 0.012 to $0.046 \mathrm{mg} / \mathrm{L}$, or about an order of magnitude lower than $\mathrm{NO}_{3}$ concentrations (fig. 15A, B). The highest $\mathrm{NH}_{4}$ concentration was observed in a near-bottom water sample at site 14 , the downstreammost waterquality sampling site, in July 1996 when the reservoir was thermally stratified and DO concentrations in nearbottom waters at the dam were low.

Ammonia concentrations measured in McDowell Creek cove (site 07, fig. 2) were similar to those measured in the mainstem (fig. 15B). Median $\mathrm{NH}_{4}$ concentrations in stormwater samples collected from McDowell Creek site $34(0.130 \mathrm{mg} / \mathrm{L})$ and site 44 $(0.120 \mathrm{mg} / \mathrm{L})$ were higher than median concentrations for site 07 near-surface $(0.014 \mathrm{mg} / \mathrm{L})$ and near-bottom $(0.040 \mathrm{mg} / \mathrm{L})$ samples. Mountain Island Lake $\mathrm{NH}_{4}$ concentrations generally were lower than those reported previously for Rhodhiss Lake and Lake Hickory. Median $\mathrm{NH}_{4}$ concentrations during 1993-94 ranged from 0.016 to $0.147 \mathrm{mg} / \mathrm{L}$ in Rhodhiss Lake (Giorgino and Bales, 1997), and from 0.050 to $0.135 \mathrm{mg} / \mathrm{L}$ in Lake Hickory (Bales and Giorgino, 1998).

In general, Mountain Island Lake near-bottom samples contained higher concentrations of $\mathrm{NH}_{4}$ than near-surface samples at all sites (fig. 15B). Seasonal variations in $\mathrm{NH}_{4}$ concentrations were not evident in near-surface samples at any of the Mountain Island Lake sites; however, $\mathrm{NH}_{4}$ concentrations in nearbottom water samples at sites 09,13 , and 14 , the sampling site nearest the dam, were consistently higher than $\mathrm{NH}_{4}$ concentrations in near-surface samples during summer 1996. Concentrations of $\mathrm{NH}_{4}$ in reservoir near-bottom waters also were strongly elevated at near-dam sites in Rhodhiss Lake and Lake 
Table 8. Statistical summary of selected water-quality properties and constituents at Mountain Island Lake mainstem sites 04, 09, and 14, May 1996-September 1997

[Max, maximum; Min, minimum; Mean, arithmetic mean; Med, median; mg/L, milligram per liter; <, less than; *, value is estimated by using a log-probability regression to predict the values of data below the minimum reporting level; $\ldots$, insufficient data to calculate statistic; $\mu \mathrm{g} / \mathrm{L}$, microgram per liter; cols $/ 100 \mathrm{~mL}$, colonies per 100 milliliters; $\dagger$, geometric mean]

\begin{tabular}{|c|c|c|c|c|c|c|c|c|c|c|c|c|}
\hline \multirow{2}{*}{ Property or constituent } & \multicolumn{4}{|c|}{ Site 04} & \multicolumn{4}{|c|}{ Site 09} & \multicolumn{4}{|c|}{ Site 14} \\
\hline & Max & Min & Mean & Med & Max & Min & Mean & Med & Max & Min & Mean & Med \\
\hline \multicolumn{13}{|c|}{ Near surface } \\
\hline Transparency, Secchi disk (meters) & 2.4 & 0.4 & 1.6 & 1.7 & 2.2 & 0.2 & 1.3 & 1.3 & 2.6 & 0.4 & 1.6 & 1.6 \\
\hline Solids, total suspended (mg/L) & 10 & $<1$ & $4^{*}$ & 2 & 35 & $<1$ & $7 *$ & 6 & 15 & $<1$ & $5^{*}$ & 4 \\
\hline Solids, volatile suspended (mg/L) & 7 & $<1$ & $2 *$ & 2 & 9 & $<1$ & $3 *$ & 3 & 28 & 1 & 5 & 3 \\
\hline $\begin{array}{l}\text { Nitrogen, nitrite plus nitrate dissolved } \\
\quad(\mathrm{mg} / \mathrm{L} \text { as } \mathrm{N})\end{array}$ & .270 & .046 & .157 & .170 & .262 & .027 & .155 & .160 & .270 & .006 & .146 & .157 \\
\hline $\begin{array}{l}\text { Nitrogen, ammonia dissolved } \\
\quad(\mathrm{mg} / \mathrm{L} \text { as } \mathrm{N})\end{array}$ & .043 & $<.002$ & $.024 *$ & .019 & .036 & $<.002$ & $.015^{*}$ & .017 & .036 & $<.002$ & $.017 *$ & .012 \\
\hline $\begin{array}{l}\text { Nitrogen, ammonia plus organic total } \\
\quad(\mathrm{mg} / \mathrm{L} \text { as } \mathrm{N})\end{array}$ & .32 & $<.20$ & $.166^{*}$ & $<.20$ & .30 & $<.20$ & - & $<.20$ & .31 & $<.20$ & - & $<.20$ \\
\hline Phosphorus, total (mg/L as $\mathrm{P}$ ) & .028 & .004 & .008 & .006 & .048 & .005 & .014 & .012 & .023 & .006 & .009 & .008 \\
\hline $\begin{array}{l}\text { Phosphorus, orthophosphate dissolved } \\
\text { (mg/L as P) }\end{array}$ & .003 & $<.001$ & $.001^{*}$ & $<.001$ & .007 & $<.001$ & $.001 *$ & $<.001$ & .006 & $<.001$ & $.001^{*}$ & $<.001$ \\
\hline $\begin{array}{l}\text { Chlorophyll } a \text { (photic-zone composite; } \\
\mu \mathrm{g} / \mathrm{L} \text { ) }\end{array}$ & 1.9 & $<.1$ & $.6^{*}$ & .5 & 2.1 & .1 & .9 & .8 & 2.3 & $<.1$ & $.7 *$ & .5 \\
\hline Fecal coliform bacteria (cols/100 mL) & 160 & $<1$ & $6 \dagger$ & 5 & 58 & $<1$ & $5 \dagger$ & 4 & 97 & $<1$ & $8 \dagger$ & 7 \\
\hline \multicolumn{13}{|c|}{ Near bottom } \\
\hline Solids, total suspended (mg/L) & 26 & $<1$ & $6^{*}$ & 4 & 92 & $<1$ & $15^{*}$ & 10 & 36 & 2 & 10 & 8 \\
\hline Solids, volatile suspended (mg/L) & 15 & $<1$ & $3 *$ & 2 & 16 & $<1$ & $5^{*}$ & 4 & 14 & $<1$ & $5^{*}$ & 3 \\
\hline $\begin{array}{l}\text { Nitrogen, nitrite plus nitrate dissolved } \\
\quad(\mathrm{mg} / \mathrm{L} \text { as } \mathrm{N})\end{array}$ & .280 & .045 & .164 & .170 & .348 & .068 & .192 & .180 & .291 & .067 & .183 & .180 \\
\hline $\begin{array}{l}\text { Nitrogen, ammonia dissolved } \\
\quad(\mathrm{mg} / \mathrm{L} \text { as } \mathrm{N})\end{array}$ & .050 & .004 & .026 & .025 & .073 & $<.002$ & $.035^{*}$ & .029 & .158 & .012 & .052 & .036 \\
\hline $\begin{array}{l}\text { Nitrogen, ammonia plus organic total } \\
(\mathrm{mg} / \mathrm{L} \text { as } \mathrm{N})\end{array}$ & .30 & $<.20$ & $.186^{*}$ & $<.20$ & .67 & $<.20$ & $.156^{*}$ & $<.20$ & .35 & $<.20$ & $.182^{*}$ & $<.20$ \\
\hline Phosphorus, total (mg/L as $\mathrm{P}$ ) & .028 & .005 & .009 & .007 & .143 & .006 & .024 & .017 & .060 & .004 & .015 & .010 \\
\hline $\begin{array}{l}\text { Phosphorus, orthophosphate dissolved } \\
\text { (mg/L as } \mathrm{P})\end{array}$ & .003 & $<.001$ & $.001^{*}$ & $<.001$ & .025 & $<.001$ & $.002 *$ & .001 & .011 & $<.001$ & $.001 *$ & $<.001$ \\
\hline
\end{tabular}




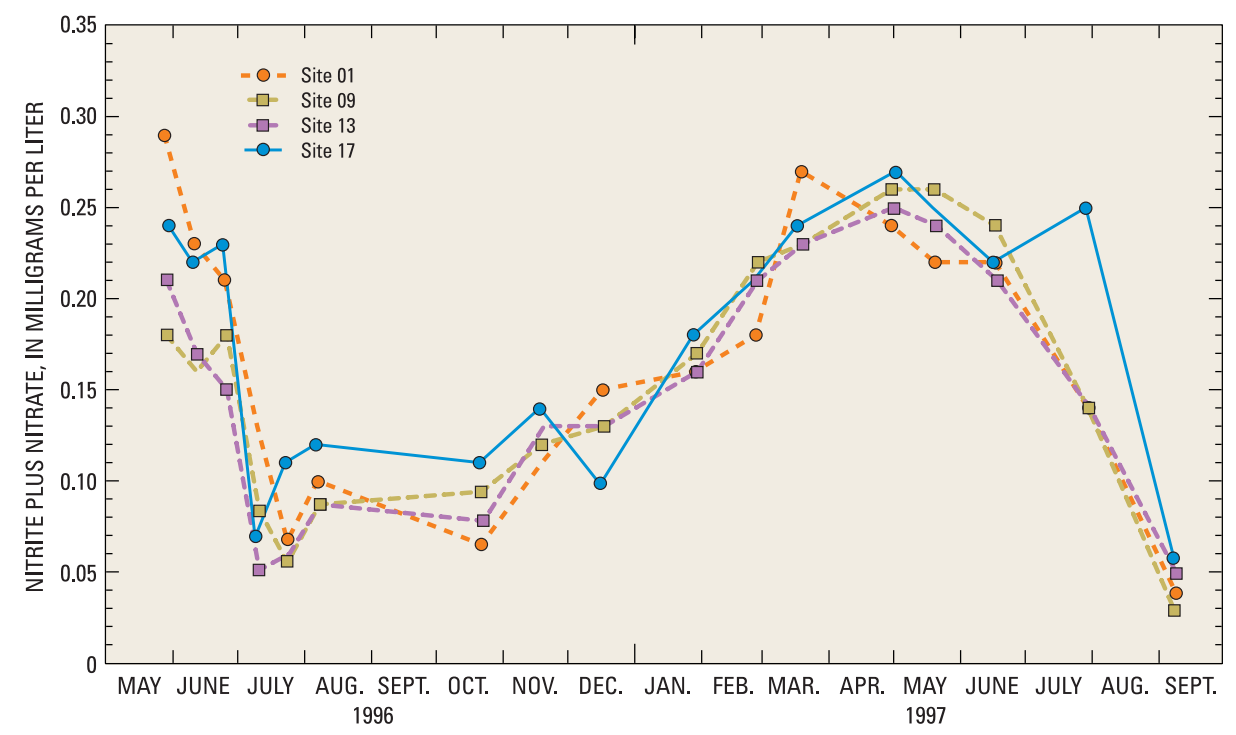

Figure 16. Concentrations of nitrite plus nitrate in surface samples collected from Mountain Island Lake sites 01, 09, 13, and 17, May 1996-September 1997.

Hickory during late summer 1993 (Giorgino and Bales, 1997; Bales and Giorgino, 1998).

Total ammonia plus organic nitrogen, or total Kjeldahl nitrogen (TKN), concentrations in Mountain Island Lake ranged from $<0.20$ to $0.80 \mathrm{mg} / \mathrm{L}$ (tables 6-8). Site 07 (McDowell Creek cove) had the highest TKN concentrations, with median concentrations of $0.43 \mathrm{mg} / \mathrm{L}$ in near-surface samples and $0.40 \mathrm{mg} / \mathrm{L}$ in near-bottom samples (table 6). At site 07 , only 6 percent of the samples contained TKN concentrations less than the minimum reporting level (MRL) of $0.20 \mathrm{mg} / \mathrm{L}$; whereas, 47 to 91 percent of the samples at the remaining Mountain Island Lake sites had TKN concentrations below the MRL. Median TKN concentrations at site 07 , however, were much lower than median concentrations in stormwater samples collected from McDowell Creek site 34 (1.700 mg/L) and site $44(1.400 \mathrm{mg} / \mathrm{L})$.

Concentrations of organic nitrogen were computed by subtracting $\mathrm{NH}_{4}$ concentration from TKN concentration, and $\mathrm{TN}$ concentrations were computed by summing $\mathrm{NO}_{3}$ and TKN. Because a high proportion of samples from Mountain Island Lake had TKN concentrations below the MRL, summary statistics for organic nitrogen and TN were not computed.

\section{Phosphorus}

Like nitrogen, phosphorus is an essential plant nutrient. In sufficient amounts, phosphorus can support undesirably high rates of vegetative production in water bodies. In addition to water-quality problems mentioned previously, nutrient enrichment can impair the quality of a water-supply source by promoting the growth of foul-tasting and odor-causing organisms and by aggravating hypolimnetic anoxia that, in turn, can lead to excessive concentrations of soluble iron and manganese. Both consequences have negative implications for treating and consuming drinking water.

Phosphorus is naturally present in water as the result of the dissolution of rock minerals in soils and geologic formations. Because phosphorus is an essential element in metabolism, it always is present in animal wastes (from both wildlife and domestic animals) and in human sewage. Phosphorus also may enter surface waters in drainage from areas where phosphate fertilizer has been applied.

Phosphorus occurs in natural waters in many forms, including dissolved phosphate anions, organic phosphates in biota, colloidal particulates, and complexes with metal oxides, especially ferric hydroxide (Hem, 1970; Wetzel, 1983). In this report, results are presented for dissolved orthophosphorus $\left(\mathrm{PO}_{4}\right)$ and TP. Phosphorus is an inorganic species that is readily available for uptake by aquatic plants. Total phosphorus includes organic and inorganic phosphorus compounds that are present in dissolved and particulate forms. 
During this investigation, $\mathrm{PO}_{4}$ and $\mathrm{TP}$ concentrations were statistically significantly higher at site 07 in the McDowell Creek cove than at other sites in Mountain Island Lake (fig. 17). At site 07, $\mathrm{PO}_{4}$ concentrations ranged from less than 0.001 to $0.210 \mathrm{mg} / \mathrm{L}$, and TP concentrations ranged from 0.011 to $0.600 \mathrm{mg} / \mathrm{L}$ (table 6). Concentrations of both phosphorous species tended to be higher in nearbottom waters than in near-surface waters at this site (fig. 17).

Median $\mathrm{PO}_{4}$ concentrations in stormwater samples collected from McDowell Creek site 34 $(0.060 \mathrm{mg} / \mathrm{L})$ and site $44(0.034 \mathrm{mg} / \mathrm{L})$ were much higher than in near-surface samples $(0.009 \mathrm{mg} / \mathrm{L})$ collected in McDowell Creek cove (site 07) and slightly higher than in near-bottom samples $(0.030 \mathrm{mg} / \mathrm{L})$. Median TP concentrations were much higher at site $34(0.480 \mathrm{mg} / \mathrm{L})$ and site $44(0.380 \mathrm{mg} / \mathrm{L})$ than those in McDowell Creek cove $(0.061 \mathrm{mg} / \mathrm{L}$ for near-surface samples and $0.109 \mathrm{mg} / \mathrm{L}$ for near-bottom samples).
Concentrations of phosphorus generally were low in the mainstem of Mountain Island Lake, in the Gar Creek cove, and at the site 13 cove (fig. 17; tables 6, 8). At these locations, $\mathrm{PO}_{4}$ ranged from less than 0.001 to $0.025 \mathrm{mg} / \mathrm{L}$, and 64 percent of the samples had concentrations less than the minimum reporting level (MRL). Total phosphorus concentrations at these sites ranged from 0.003 to $0.143 \mathrm{mg} / \mathrm{L}$, and median concentrations were less than $0.020 \mathrm{mg} / \mathrm{L}$ (tables 6,8 ). No seasonal variations in phosphorus concentrations were observed at any of the Mountain Island Lake sites.

The low phosphorus concentrations in the mainstem of Mountain Island Lake reflected characteristics of the inflow from Lake Norman. The North Carolina DWQ monitored nutrients in all of the Catawba River mainstem reservoirs during the summer of 1997, and the results of their investigation for Mountain Island Lake were similar to the results of this investigation during that time period. Furthermore, during June-August 1997, concentrations of TP in
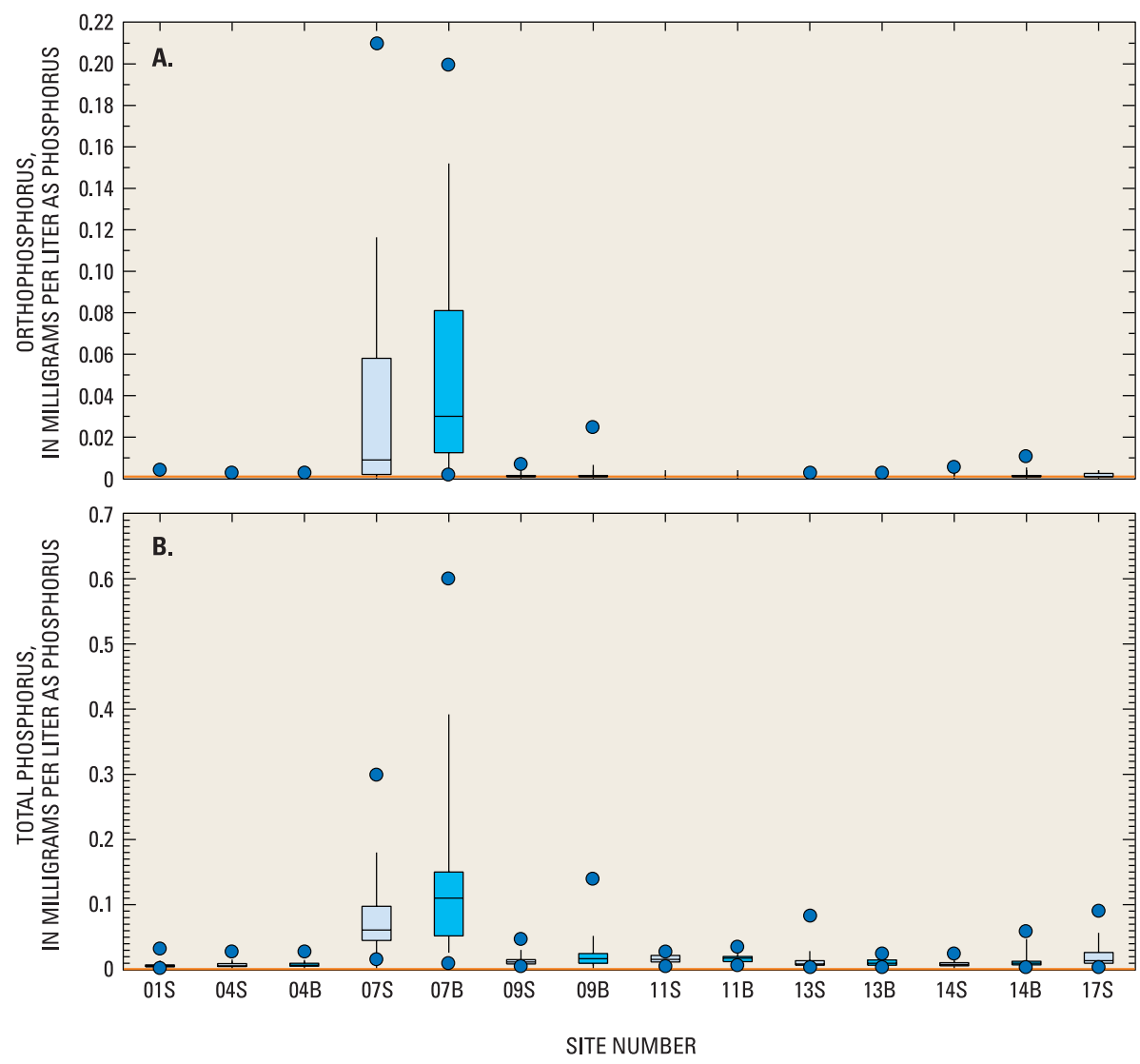

EXPLANATION

- - DATA VALUES OUTSIDE THE $10^{\text {th }}$ and $90^{\text {th }}$ PERCENTILES

$-90^{\text {th }}$ PERCENTILE

$-75^{\text {th }}$ PERCENTILE -MEDIAN

$-25^{\text {th }}$ PERCENTILE

$-10^{\text {th }}$ PERCENTILE

- MINIMUM REPORTING LEVEL

$S$ Near surface

B Near bottom

Figure 17. Distributions of concentrations of $(A)$ orthophosphorus and $(B)$ total phosphorus at Mountain Island Lake sites, May 1996-September 1997. 
Lake Norman directly upstream from Cowans Ford Dam were less than or equal to $0.01 \mathrm{mg} / \mathrm{L}$, consistent with concentrations measured in the headwaters of Mountain Island Lake (site 01). With the exception of site 07, lower TP concentrations were detected in Mountain Island Lake than in Rhodhiss Lake, Lake Hickory, and Lake Wylie during the summer of 1997 (D. Owen, North Carolina Division of Water Quality, written commun., September 1999). Phosphorus concentrations in the mainstem of Mountain Island Lake also were lower than those reported previously for Rhodhiss Lake and Lake Hickory. During 1993-94, median TP concentrations ranged from 0.034 to $0.086 \mathrm{mg} / \mathrm{L}$ at sites in Rhodhiss Lake (Giorgino and Bales, 1997), and from 0.019 to $0.054 \mathrm{mg} / \mathrm{L}$ in Lake Hickory (Bales and Giorgino, 1998).

\section{Chlorophyll a}

During this investigation, chlorophyll $a$ samples were collected as vertical composites of the euphotic zone (Sarver and Steiner, 1998). Analysis was performed by using high-performance liquid chromatography, which does not require a separate correction for chlorophyll degradation products, such as pheophytin.

Concentrations of chlorophyll $a$ generally were low throughout Mountain Island Lake, ranging from $<0.1$ to $13 \mu \mathrm{g} / \mathrm{L}$ (tables $6-8$ ). The maximum concentration was observed at McDowell Creek cove site 07 during July 1996. Although chlorophyll $a$ concentrations were statistically significantly higher in McDowell Creek cove than at all other sites in the Mountain Island Lake study area, the mean of all summer (May-September) concentrations at site 07 was less than $5 \mu \mathrm{g} / \mathrm{L}$ and, thus, did not indicate problematic levels of algal productivity. During JuneAugust 1997, the North Carolina DWQ reported an average chlorophyll $a$ concentration of $8.7 \mu \mathrm{g} / \mathrm{L}$ for McDowell Creek cove and average concentrations of $2 \mu \mathrm{g} / \mathrm{L}$ at five other sites in Mountain Island Lake (D. Owen, North Carolina Division of Water Quality, written commun., September 29, 1999). Similar values were measured during a 1993-94 investigation conducted by Mecklenburg County and the North Carolina DWQ (Mecklenburg County Department of Environmental Protection, 1995; North Carolina Department of Environment, Health, and Natural Resources, 1996). Although nutrient concentrations were elevated in McDowell Creek upstream from Mountain Island Lake, algal bloom conditions were not observed in the McDowell Creek cove (North Carolina Department of Environment and Natural Resources, 1999a).

Chlorophyll $a$ concentrations in southeastern U.S. reservoirs typically vary seasonally, peaking during spring and(or) summer and declining during winter. With the exception of site 07 , concentrations of chlorophyll $a$ at sites in Mountain Island Lake were so low that seasonal variations were not very pronounced. At all Mountain Island Lake sites, excluding site 07, summer mean concentrations were less than $2 \mu \mathrm{g} / \mathrm{L}$, and all samples from these sites contained less than $4 \mu \mathrm{g} / \mathrm{L}$ chlorophyll $a$ (tables $6-8$ ). No samples collected during the Mountain Island Lake study exceeded the North Carolina water-quality standard for chlorophyll $a$ of $40 \mu \mathrm{g} / \mathrm{L}$ (North Carolina Department of Environment, Health, and Natural Resources, 1997).

\section{Discussion of Water-Quality Conditions}

As a whole, Mountain Island Lake is generally riverine in nature with transient stratification. Thermal stratification occasionally was observed in a localized area around sites 14 and 15 downstream from the cooling water discharge at the Riverbend Steam Station. Concentrations of chemical constituents were relatively uniform throughout the reservoir mainstem during individual sampling events and were governed largely by concentrations in the inflow through Cowans Ford Dam.

Because Mountain Island Lake is hydraulically more riverine than lacustrine, it was not unexpected that differences between near-surface and near-bottom concentrations of nutrients were negligible at the more riverine (or upstream) sites 01 and 04 , and that vertical differences became only slightly more pronounced farther downstream at sites 09 and 14. At the latter two sites, near-bottom concentrations of $\mathrm{NH}_{4}$ tended to be greater than near-surface concentrations during warm months, but vertical differences and seasonality were not as pronounced as previously measured at lacustrine sites in other Catawba River reservoirs. Concentrations of $\mathrm{NO}_{3}$ in Mountain Island Lake were strongly seasonal, peaking in spring and early summer and declining in late summer and fall.

Water-quality results from site 07 indicated that the McDowell Creek cove contained relatively higher concentrations of $\mathrm{NO}_{3}$, total ammonia plus organic nitrogen, $\mathrm{PO}_{4}, \mathrm{TP}$, and chlorophyll $a$ compared to other sites in Mountain Island Lake. Concentrations of 
chlorophyll $a$ measured at site 07 , however, were not indicative of water-quality problems during this investigation.

McDowell Creek is included in the North Carolina 2000 draft 303(d) list of impaired waters. Sources of impairment include nutrient enrichment from the McDowell Creek WWTP, nonpoint sources, streambank erosion, and in-stream habitat degradation (North Carolina Department of Environment and Natural Resources, 1999b). The McDowell Creek WWTP recently doubled its capacity from 11,400 cubic meters per day $\left(\mathrm{m}^{3} / \mathrm{d}\right)$ to $22,800 \mathrm{~m}^{3} / \mathrm{d}$ (November 1998) and added a nutrient-removal system (March 1999). In addition, stringent nutrient limits were placed on effluents by the State of North Carolina. Since the nutrient-removal system became fully functional, TP levels in McDowell Creek downstream from the WWTP have decreased substantially (Mecklenburg County Department of Environmental Protection, 2000). These changes suggest that nonpoint sources have an even greater effect than point sources on water quality in Mountain Island Lake.

\section{SIMULATION OF HYDRODYNAMICS AND MATERIAL TRANSPORT}

A two-dimensional, laterally averaged model was constructed for Mountain Island Lake and was calibrated and tested by using data collected during April 1996-September 1997. Water levels; longitudinal and vertical currents; heat transport and temperature distribution; conservative material transport, mixing, and dilution; and the transport and biochemical transformation of 12 constituents were simulated by the Mountain Island Lake water-quality model.

The numerical modeling code known as CE-QUAL-W2 was configured for application to Mountain Island Lake. This particular code was selected for the following reasons:

- Successful application to two other reservoirs in the Catawba River Basin (Giorgino and Bales, 1997; Bales and Giorgino, 1998);

- Availability of thorough documentation of both the theoretical aspects of the model and of applications in a variety of settings (Cole and Buchak, 1995);
- Robust and stable numerical solutions to the complete, nonlinear equations of motion and transport;

- Realistic treatment of reservoir nutrient, algal, and DO dynamics; and

- Capability of the model to simulate processes in the reservoir mainstem and coves, as well as interaction between the two.

\section{Data for Model Application}

The general form of CE-QUAL-W2 was configured for the Mountain Island Lake application by (1) developing a computational grid that provides a realistic approximation to the reservoir bathymetry; (2) specifying boundary conditions, which are primarily exchanges of mass and heat at the upstream, downstream, water-surface, and reservoir-bottom boundaries; and (3) specifying model parameters. Boundary data were available for the period April 18, 1996-September 30, 1997, referred to as the simulation period. Selected model parameters were adjusted during calibration and testing of the model.

\section{Computational Grid}

The physical domain of the Mountain Island Lake numerical model extends from the N.C. Highway 73 bridge near Cowans Ford Dam (site 01, segment 2) to Mountain Island Dam (site 51, segment 37), which is a distance of $24.9 \mathrm{~km}$ along the mainstem of the reservoir (figs. 2, 18). The model domain includes

- Four embayments (fig. 18)-McDowell Creek cove (branch 2), the cove between McDowell Creek and Gar Creek (branch 3), Gar Creek cove (branch 4), and the cove downstream from Gar Creek (branch 5).

- Three point sources (fig. 18)—Riverbend Steam Station ash settling pond discharge (segment 17), Riverbend Steam Station thermal discharge (segment 33), and McDowell Creek WWTP discharge (segment 40).

- Three withdrawals (fig. 18)—Riverbend Steam Station intake (segment 12), CharlotteMecklenburg Utilities water-supply intake (segment 29), and the combined Mount Holly and Gastonia withdrawals (segment 37). 


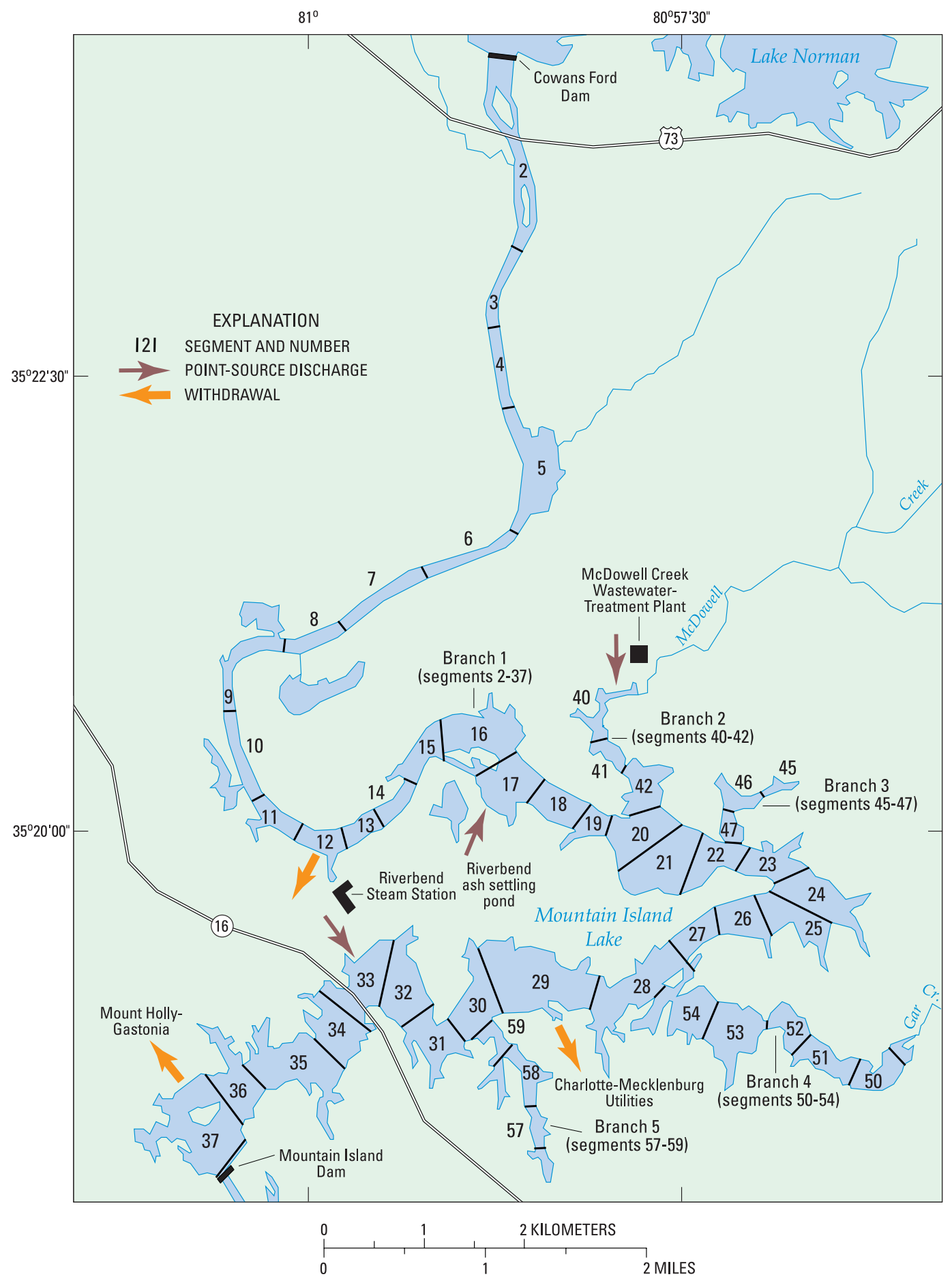

Figure 18. Plan view of the top layer of computational grid for Mountain Island Lake water-quality model. 
Reservoir bathymetry was measured in April 1997 by using a recording fathometer with a digital output and a global positioning unit. Cross-sectional geometry was measured at 56 transects that corresponded approximately to the location of the segments shown in figure 18. Data from these measurements were used to develop the computational grid.

The mainstem of the reservoir is represented by 36 computational segments, and each of the embayments is represented by at least 3 segments (fig. 18). Segments range in length from 420 to $1,140 \mathrm{~m}$, with longer segments typically located in the upstream, more riverine reach of the reservoir.

Full-pond elevation of the reservoir, or the elevation at the crest of the spillway, is $197.41 \mathrm{~m}$ above sea level. Additional storage is available above elevation 197.41, but the water level at the dam during this study reached a maximum elevation of $196.18 \mathrm{~m}$. Measured reservoir bottom elevations ranged from about $192.5 \mathrm{~m}$ directly downstream from Cowans Ford Dam to about $178 \mathrm{~m}$ about $0.4 \mathrm{~km}$ upstream from Mountain Island Dam.

Each segment was divided into computational layers. All layers were $1 \mathrm{~m}$ thick, and the number of computational layers within the mainstem segment ranged from 8 to 20 (for example, segment 37; fig. 19).

The volume of Mountain Island Lake at elevation 197.41 m calculated from the computational grid, which is an approximation of the actual volume, is 65.17 million $\mathrm{m}^{3}$. According to Duke Power (T. Ziegler, Duke Power, written commun., July 1999), the volume of the reservoir estimated from prereservoir surveys is 72.95 million $\mathrm{m}^{3}$, or about 11 percent more than the reservoir volume estimated from the computational grid. The volume of the reservoir also has been reported as 71 million $\mathrm{m}^{3}$ (North Carolina Department of Environment, Health, and Natural Resources, 1992). The difference between the volume estimated from the computational grid (and associated 1997 bathymetric measurements) and the volume estimated from prereservoir surveys most likely is due to sediment accumulation in the reservoir, particularly between 1924, when Mountain Island Dam was completed, and 1967, when Cowans Ford Dam was completed. Other possible reasons for the difference between the two estimates of reservoir volume may be errors in ground (preconstruction) and bathymetric (1997) surveys, errors associated with interpolation between survey

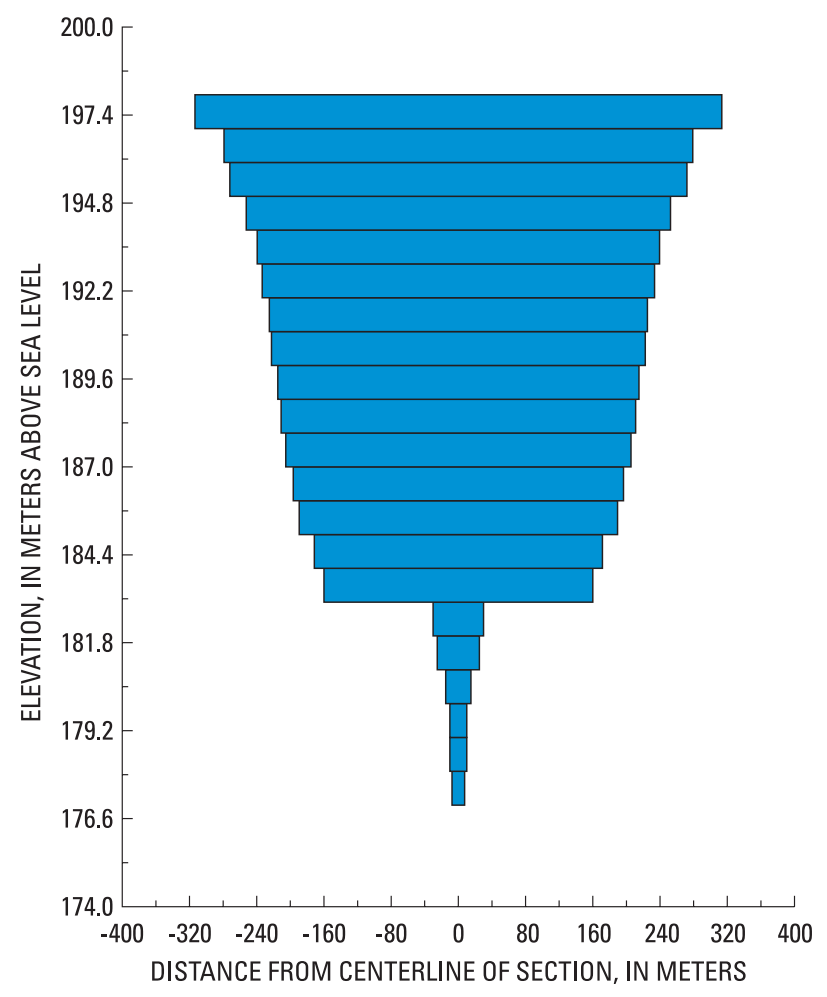

Figure 19. Elevation view of computational layers at model segment 37 for Mountain Island Lake water-quality model.

points, and(or) errors associated with representing the volume by the computational grid.

\section{Boundary Conditions}

Boundary conditions generally can be described as a time series of data that define the inflows of momentum, mass, and heat to the model domain, and the outflows of water from the model domain. Outflows of heat and chemical constituents from the model domain do not need to be predefined, but are simulated by the model. The boundary conditions for the Mountain Island Lake water-quality model are described in this section.

\section{Flow}

Inflow boundary conditions (table 9) were determined in the following manner:

- Branch 1, flow from Cowans Ford Dam: Hourly flow data for the period April 1, 1996September 30, 1997, were provided by Duke Power (J.E. Smith, Duke Power, written commun., February 1998). A constant leakage 
Table 9. Range of values for selected inflow and outflow boundary conditions for the Mountain Island Lake water-quality model

[WWTP, wastewater-treatment plant; $\mathrm{m}^{3} / \mathrm{s}$, cubic meter per second; ${ }^{\circ} \mathrm{C}$, degree Celsius; $\mathrm{mg} / \mathrm{L}$, milligram per liter; BOD, biochemical oxygen demand; CMU, Charlotte-Mecklenburg Utilities]

\begin{tabular}{|c|c|c|c|c|c|c|c|c|}
\hline \multicolumn{9}{|c|}{ Range of values for specific locations } \\
\hline \multicolumn{9}{|c|}{ Inflows } \\
\hline Data type (units) & Branch 1 & Branch 2 & Branch 3 & Branch 4 & Branch 5 & $\begin{array}{c}\text { Riverbend } \\
\text { ash settling } \\
\text { pond }\end{array}$ & $\begin{array}{c}\text { Riverbend } \\
\text { Steam } \\
\text { Station }\end{array}$ & $\begin{array}{c}\text { McDowel } \\
\text { Creek } \\
\text { WWTP }\end{array}$ \\
\hline Flow $\left(\mathrm{m}^{3} / \mathrm{s}\right)$ & $2.3-958$ & $0.06-214$ & $0.04-117$ & $0.01-21.2$ & $0.04-117$ & $0.124-0.273$ & $0-27.2$ & $\begin{array}{c}0.00049- \\
0.00167\end{array}$ \\
\hline $\begin{array}{l}\text { Temperature } \\
\left({ }^{\circ} \mathrm{C}\right)\end{array}$ & $7.8-29.8$ & $0.1-33.0$ & $0.1-33.0$ & $0.4-27.5$ & $0.4-27.5$ & $9.0-28.0$ & $11.9-35.8$ & $14.0-24.7$ \\
\hline $\begin{array}{l}\text { Suspended solids } \\
(\mathrm{mg} / \mathrm{L})\end{array}$ & $1-8$ & $3-2,980$ & 0 & $82-4,900$ & 0 & 0 & 0 & 0 \\
\hline Ammonia (mg/L) & $0.008-0.068$ & $0.011-0.48$ & 0.005 & $0.006-0.84$ & 0.005 & 0 & $0.004-0.050$ & $0.02-0.63$ \\
\hline Nitrate $(\mathrm{mg} / \mathrm{L})$ & $0.038-0.27$ & $0.177-1.03$ & 0.10 & $0.104-0.83$ & 0.10 & 0 & $0.050-0.28$ & $4.1-15.5$ \\
\hline $\begin{array}{l}\text { Orthophosphorus } \\
\quad(\mathrm{mg} / \mathrm{L})\end{array}$ & $0.001-0.004$ & $0.001-0.16$ & 0.001 & $0.006-0.80$ & 0.001 & $0.016-0.050$ & 0.001 & $0.25-2.1$ \\
\hline $\begin{array}{l}\text { Dissolved oxygen } \\
\quad(\mathrm{mg} / \mathrm{L})\end{array}$ & $5.3-10.1$ & $4.1-10$ & $5.3-10.1$ & $4.1-10$ & $5.3-10.1$ & $6.0-9.0$ & $5.7-10.3$ & $7.6-9.5$ \\
\hline Iron $(\mathrm{mg} / \mathrm{L})$ & $0.03-0.08$ & 0.15 & 0.05 & 0.15 & 0.05 & $0.030-0.116$ & $0.06-0.56$ & 0.05 \\
\hline $\mathrm{BOD}(\mathrm{mg} / \mathrm{L})$ & 1.0 & $0.1-11.4$ & 1.0 & $0.8-8.3$ & 1.0 & 1.0 & 1.0 & $1.3-6.4$ \\
\hline $\begin{array}{l}\text { Particulate organic } \\
\text { matter }(\mathrm{mg} / \mathrm{L})\end{array}$ & $1-6$ & $1-390$ & 1 & $6-390$ & 1 & $1.0-4.2$ & $1-15$ & $4.0-21.1$ \\
\hline Algae (mg/L) & $0.001-0.06$ & 0.01 & 0.001 & 0.01 & 0.001 & 0 & 0 & 0 \\
\hline \multicolumn{9}{|c|}{ Outflows/Withdrawals } \\
\hline & Branch 1 & $\begin{array}{l}\text { Riverbend } \\
\text { Steam } \\
\text { Station }\end{array}$ & $\begin{array}{l}\text { CMU } \\
\text { with- } \\
\text { drawal }\end{array}$ & $\begin{array}{c}\text { Combined } \\
\text { Mount Holly } \\
\text { and } \\
\text { Gastonia } \\
\text { withdrawal } \\
\end{array}$ & & & & \\
\hline Flow $\left(\mathrm{m}^{3} / \mathrm{s}\right)$ & $2.3-290$ & $0-27.2$ & $2.24-8.6$ & $0.05-2.4$ & & & & \\
\hline
\end{tabular}

rate of $2.27 \mathrm{~m}^{3} / \mathrm{s}$ was assumed (T. Ziegler, Duke Power, oral commun., July 1998). Data were missing for a few days (for example, early June 1997), and flows were estimated for these periods.

- Branch 2, McDowell Creek: Flow was estimated from the two streamgages on McDowell Creek (sites 34 and 44; fig. 2). For the simulation period prior to the installation of the streamgage at site 44 (April 18-November 25, 1996), hourly streamflow data from site 34 (drainage area $=6.10 \mathrm{~km}^{2}$ ) were extrapolated to the mouth of McDowell Creek (drainage area $=75.9 \mathrm{~km}^{2}$ ) by assuming the unit runoff at site 34 was the same as the unit runoff for the entire basin. For the remainder of the simulation period, hourly streamflow data from site 44 (drainage area $=68.1 \mathrm{~km}^{2}$ ) were extrapolated to the mouth of McDowell Creek by again assuming constant unit runoff for site 44 and the entire basin. Extrapolation of data from site 34 probably resulted in an overestimation of streamflow at the mouth of the creek (fig. 20). Streamflows from McDowell Creek were quite small, however, relative to discharges through Cowans Ford Dam (table 3). 


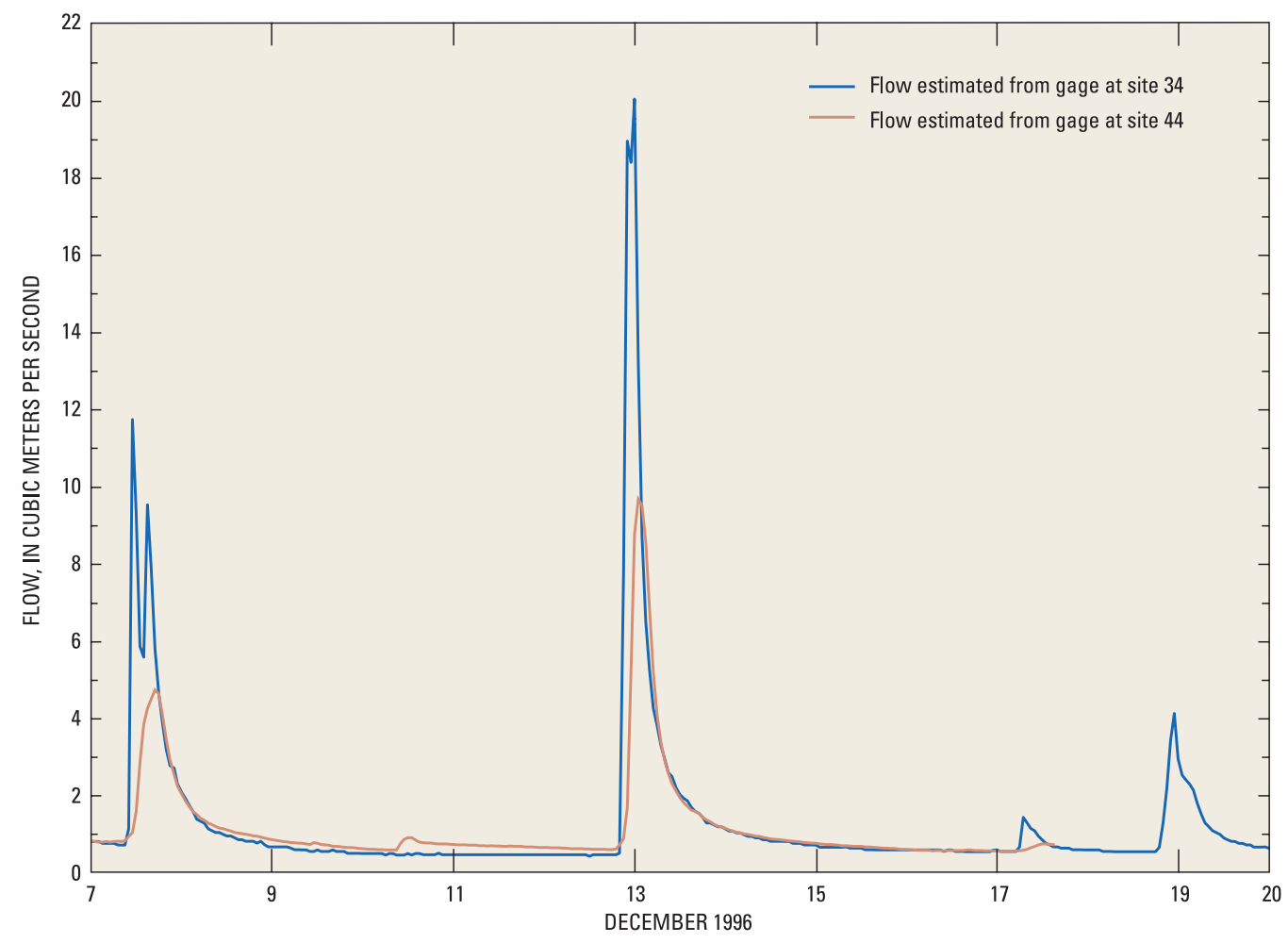

Figure 20. Comparison of streamflow at the mouth of McDowell Creek (drainage area $=75.9$ square kilometers) estimated from measured streamflow at site 34 (drainage area $=6.10$ square kilometers) and site 44 (drainage area $=68.1$ square kilometers).

- Branch 4, Gar Creek: Flow at the mouth of Gar Creek (drainage area $=13.2 \mathrm{~km}^{2}$ ) was estimated from measured hourly flow at site 33 (drainage area $=6.92 \mathrm{~km}^{2}$ ) by assuming that unit runoff at site 33 was the same as at the mouth of Gar Creek.

- Branches 3 and 5, ungaged areas: The total Catawba River drainage area increases from $4,639 \mathrm{~km}^{2}$ at Cowans Ford Dam to $4,820 \mathrm{~km}^{2}$ at Mountain Island Dam, an increase of only $181 \mathrm{~km}^{2}$. About half $\left(89.1 \mathrm{~km}^{2}\right)$ of that increase is accounted for by the McDowell and Gar Creek Basins. Of the remaining ungaged drainage area $\left(91.9 \mathrm{~km}^{2}\right)$ between Cowans Ford and Mountain Island Dams, half was assigned to branch 3 and half was assigned to branch 5 . The unit runoff in these two ungaged areas was assumed to be equal to the average of the unit runoff from the McDowell and Gar Creek Basins as determined from measured streamflow.
- Riverbend ash settling pond discharge: Monthly mean discharges from the Riverbend Steam Station ash settling pond were provided by the North Carolina DWQ as part of the compliance monitoring program (M.E. Lieber, North Carolina Division of Water Quality, written commun., September 1998). The discharge enters Mountain Island Lake in model segment 17 (fig. 18).

- Riverbend Steam Station discharge: Daily mean discharge from Riverbend Steam Station was provided by Duke Power (J. Knight, Duke Power, written commun., July 1998). The discharge enters Mountain Island Lake in model segment 33, just upstream from site 14 at the N.C. Highway 16 bridge (fig. 18). With only a few exceptions, daily mean discharges from the steam station were equal to daily mean withdrawals from the reservoir for station operation (fig. 21). 


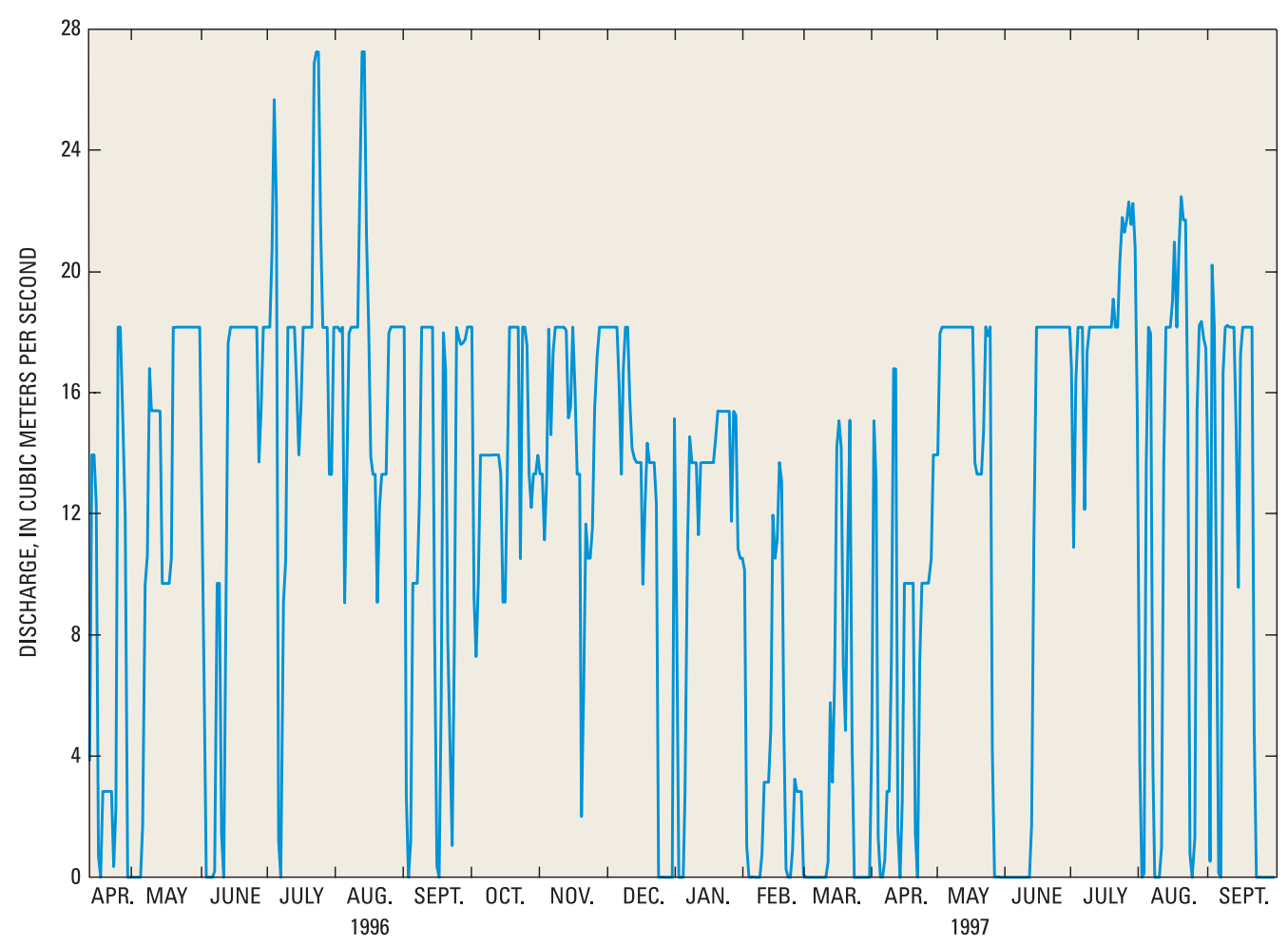

Figure 21. Daily mean withdrawals from Mountain Island Lake by the Riverbend Steam Station, April 1996-September 1997; releases by the steam station to the lake were equivalent to withdrawals.

- McDowell Creek WWTP discharge: Monthly mean discharges from the McDowell Creek WWTP were provided by the North Carolina DWQ as part of the compliance monitoring program (M.E. Lieber, North Carolina Division of Water Quality, written commun., September 1998). Discharge is treated as a tributary stream to McDowell Creek and enters the model domain in segment 40 (fig. 18).

Outflow boundary conditions (table 9) included the following:

- Riverbend Steam Station: Estimates of daily mean withdrawals by the Riverbend Steam Station from Mountain Island Lake were provided by Duke Power (T. Ziegler, Duke Power, written commun., July 1998). The withdrawal occurs in model segment 12 (fig. 18).
- Water-supply withdrawals: Three water-supply intakes were located in Mountain Island Lake during the study period. The CharlotteMecklenburg Utilities withdrawal occurs in segment 29, and the Gastonia and Mount Holly withdrawals occur in segment 37 near Mountain Island Dam (fig. 18). Because the Gastonia and Mount Holly withdrawals occur in the same computational segment of the model, these two withdrawals were combined and treated as a single outflow in the model. Daily mean values of water-supply withdrawals were provided by Charlotte-Mecklenburg Utilities (T. Huffstickler, Charlotte-Mecklenburg Utilities, Franklin Water Treatment Plant, written commun., September 1998), the City of Gastonia (M. Bynum, City of Gastonia Public Works/Utilities Department, written commun., September 1998), and the City of Mount Holly (E. Nichols, City of Mount Holly, written commun., September 1998). 
- Mountain Island Dam discharge: Hourly flow data for the period April 1, 1996-September 30, 1997, were provided by Duke Power (J.E. Smith, Duke Power, written commun., February 1998). A constant leakage rate of $2.27 \mathrm{~m}^{3} / \mathrm{s}$ was assumed (T. Ziegler, Duke Power, oral commun., July 1998). Flows were estimated for the few days where data were missing.

The difference between precipitation on the reservoir and evaporation from the reservoir was quite small relative to other terms in the water balance (table 3). On an annual basis, the difference is less than $0.1 \mathrm{~m}^{3} / \mathrm{s}$. Consequently, a time series of rainfall on the reservoir was not included as a hydraulic boundary condition (or water input), and evaporation from the reservoir was not simulated.

\section{Water Temperature}

Water temperature was measured at 15-minute intervals at site 01 from April 18, 1996, to September 30, 1997 (Sarver and Steiner, 1998). Hourly temperature data from site 01 were used as the upstream temperature boundary condition for branch 1 . Data were missing during the period July 16-24, 1996. Water temperature during this period was estimated from a linear interpolation between the last recorded value on July 16 to the first recorded value on July 24 . Measurements confirmed that the water column was well mixed thermally at site 01 , so there was no need to provide a time series of the vertical distribution of water temperature as a boundary condition.

Water temperature also was measured at 15 minute intervals at one site on Gar Creek (site 33) and two sites on McDowell Creek (sites 34 and 44). Data were available for sites 33 and 34 throughout the period of this investigation, with the exception of a few instances of missing record. Water temperature records at site 44 began on November 26, 1996, and continued through September 24, 1997.

Data collected at site 33 were used as the upstream temperature boundary condition for branches 4 (Gar Creek) and 5. The only period of missing record at site 33 was June 21-July 1, 1996, and data from site 34 were used as an estimate of water temperature at site 33 during this period. Prior to November 26, 1996, data from site 34 were used as the upstream temperature boundary condition for branches 2 (McDowell Creek) and 3. For the remainder of the simulation period, data from site 44 , which was closer to the mouth of McDowell Creek than site 34, were used as the temperature boundary condition for branches 2 and 3. The few periods of missing record at sites 34 and 44 were estimated by using data from site 33. Water temperature measured at site 34 does not appear to completely reflect the full range of fluctuations or maximum water temperatures measured at site 44 during the summer (fig. 22).

The discharge from Riverbend Steam Station to Mountain Island Lake is heated above ambient water temperature. Daily mean water temperatures for the discharge were provided by Duke Power (T. Ziegler, Duke Power, written commun., July 1998). Monthly mean water temperature for the Riverbend ash settling pond discharge was assumed to be approximately equal to monthly mean air temperature. Because the flow from the settling pond is extremely small relative to other inflows, reasonable assumptions about the temperature of this inflow were not expected to affect simulations of temperature in the reservoir. Monthly mean water temperature for the McDowell Creek WWTP discharge was provided by the North Carolina DWQ (M.E. Lieber, North Carolina Division of Water Quality, written commun., September 1998).

\section{Water Chemistry}

Concentrations of the following constituents were simulated for Mountain Island Lake: (1) a conservative, neutrally buoyant tracer, (2) total suspended solids, (3) labile dissolved organic matter, (4) refractory dissolved organic matter, (5) algae, (6) particulate organic matter, (7) $\mathrm{NO}_{3},(8) \mathrm{NH}_{4}$, (9) $\mathrm{PO}_{4},(10) \mathrm{DO},(11)$ organic bottom sediments, (12) iron, and (13) BOD. These same constituents are included in the Rhodhiss Lake (Giorgino and Bales, 1997) and Lake Hickory (Bales and Giorgino, 1998) water-quality models, with the addition of suspended solids to the Mountain Island Lake model.

Inflow chemical boundary conditions were prescribed for the following constituents: (1) a conservative tracer; (2) total suspended solids (for branches 1, 2, and 5 only); (3) algae, (4) particulate organic matter, (5) $\mathrm{NO}_{3}$, (6) $\mathrm{NH}_{4}$, (7) $\mathrm{PO}_{4}$, (8) DO, (9) iron, and (10) BOD. Algal concentrations were estimated by multiplying chlorophyll $a$ concentrations (in micrograms per liter) by the factor 0.067 (American Public Health Association and others, 1992; Cole and Buchak, 1995). Only inflow water-chemistry boundary conditions are required, and boundary conditions are 


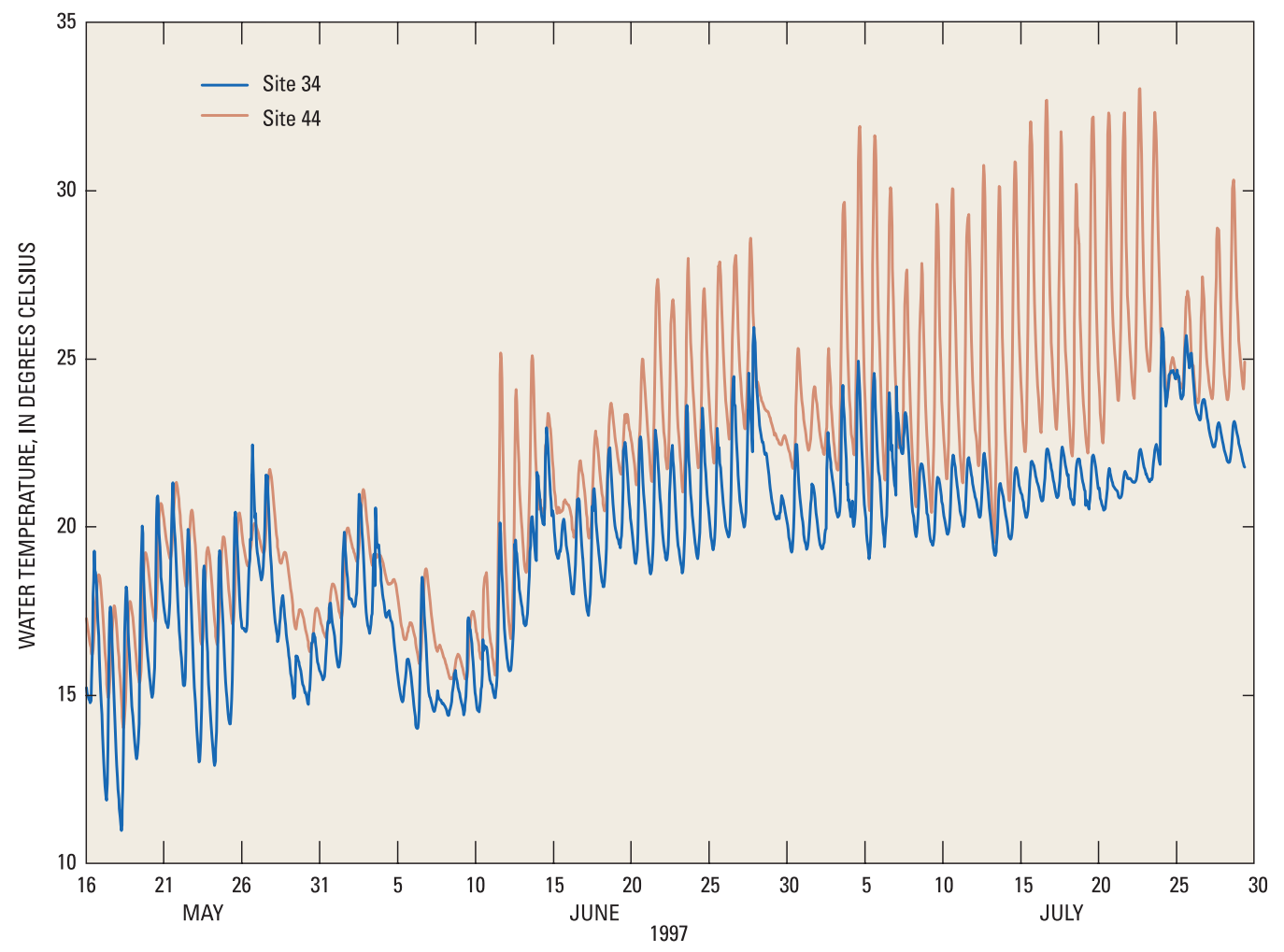

Figure 22. Water temperature measured in McDowell Creek at sites 34 and 44 during May 16-July 30, 1997.

not required for all constituents included in the model simulations. Water-chemistry boundary conditions (table 9) were determined in the following manner.

- Branch 1, flow through Cowans Ford Dam: Water-chemistry inflow boundary conditions at the upstream end of the model domain were based on a set of 17 monthly to semimonthly measurements at site 01 (Sarver and Steiner, 1998). Flow was not a good predictor of water chemistry at this site, but fairly consistent temporal patterns were evident in the data (fig. 23). Nitrate concentrations varied seasonally, whereas total suspended solids, $\mathrm{NH}_{4}, \mathrm{PO}_{4}$, and iron were fairly constant throughout the period. Algae also was fairly constant but was only measured during 1996; the 1996 values were used to estimate 1997 concentrations. Algal concentrations at site 01 were quite low, with chlorophyll $a$ concentrations always less than $0.6 \mu \mathrm{g} / \mathrm{L}$. Although DO was measured continuously at site 01 , the continuous records of DO were not used for the boundary condition. Rather, to be consistent with the other water-chemistry constituents, DO measured at the time of water-sample collection was used as the boundary condition. Volatile suspended-sediment concentrations were used as a direct measure of particulate organic matter. All BOD values were reported as less than $2 \mathrm{mg} / \mathrm{L}$ (Sarver and Steiner, 1998). BOD was assumed to be constant at $0.5 \mathrm{mg} / \mathrm{L}$. Concentrations of $\mathrm{PO}_{4}$ in 11 of 17 samples were less than the detection limit of $0.001 \mathrm{mg} / \mathrm{L}$. Orthophosphorus concentrations in these samples were assumed to be $0.0001 \mathrm{mg} / \mathrm{L}$.

- Branch 2, McDowell Creek: Water-chemistry boundary conditions for McDowell Creek were generated by using loading equations developed for site 34 (Bales and others, 1999). The loading equations can be used to compute constituent load from streamflow and calendar date. Loading equations were available for (1) total suspended sediment, (2) TN, (3) TP, and (4) BOD, as well as several other constituents not used in the Mountain Island Lake waterquality model. 


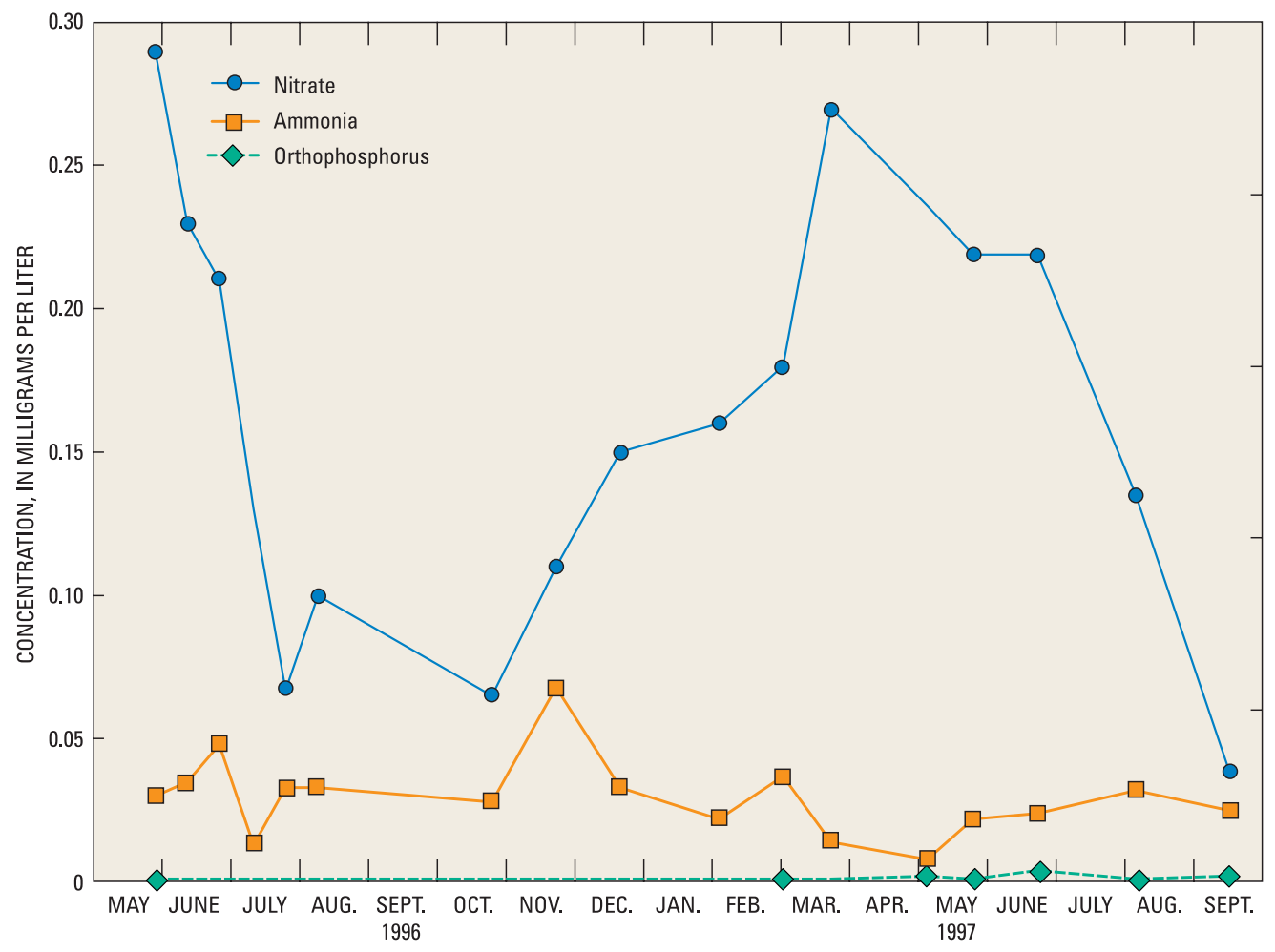

Figure 23. Concentrations of nitrate, ammonia, and orthophosphorus at site 01 directly downstream from Cowans Ford Dam, May 28, 1996-September 9, 1997.

Daily streamflow at site 34 was used to calculate daily loads and, subsequently, daily mean concentrations of suspended sediment, TN, TP, and BOD at site 34 . Daily mean concentrations calculated for site 34 were assumed to be equal to daily mean concentrations of nonpoint-source export at the mouth of McDowell Creek. (Point-source contributions from the McDowell Creek WWTP were added to Mountain Island Lake inflows separately from McDowell Creek nonpoint-source loads.)
The assumption of equal concentrations at site 34 and the mouth of McDowell Creek was checked by using the available water-chemistry data collected nearly simultaneously at sites 34 and 44. On May 7, 1997, during nonstorm conditions, water-quality conditions at sites 34 and 44 were similar (table 10). Likewise, during a storm on July 22-23, 1997, during which more than $10 \mathrm{~cm}$ of rain fell in the McDowell Creek Basin, maximum measured concentrations at the two sites were similar (table 10).

Table 10. Comparison of selected constituent concentrations measured nearly simultaneously at two locations on McDowell Creek during low-flow and stormflow conditions

$\left[\left(\mathrm{m}^{3} / \mathrm{s}\right) / \mathrm{km}^{2}\right.$, cubic meter per second per square kilometer; $\mu \mathrm{S} / \mathrm{cm}$, microsiemens per centimeter at 25 degrees Celsius; NA, not applicable; $\mathrm{mg} / \mathrm{L}$, milligram per liter; $<$ less than]

\begin{tabular}{|c|c|c|c|c|}
\hline \multirow[t]{2}{*}{ Constituent (units) } & \multicolumn{2}{|c|}{$\begin{array}{l}\text { May } 7,1997 \text { (low flow) } \\
\text { single observation }\end{array}$} & \multicolumn{2}{|c|}{$\begin{array}{c}\text { July 22-23, } 1997 \text { (stormflow) } \\
\text { maximum observed }\end{array}$} \\
\hline & Site 34 & Site 44 & Site 34 & Site 44 \\
\hline Discharge $\left(\left[\mathrm{m}^{3} / \mathrm{s}\right] / \mathrm{km}^{2}\right)$ & 0.72 & 0.72 & 225 & 34 \\
\hline Specific conductance $(\mu \mathrm{S} / \mathrm{cm})$ & 111 & 129 & NA & NA \\
\hline Total nitrogen (mg/L) & .87 & .77 & 3.8 & 3.4 \\
\hline Total phosphorus (mg/L) & .041 & .050 & .97 & 1.18 \\
\hline Biochemical oxygen demand (mg/L) & $<2.0$ & $<2.0$ & 17 & 10 \\
\hline
\end{tabular}


Data collected at sites 34 and 44 (Robinson, Hazell, and Garrett, 1998) were used to evaluate the relations between calculated constituents (total suspended sediment, TN, and TP) and constituents required for model application (volatile suspended solids, $\mathrm{NO}_{3}, \mathrm{NH}_{4}$, and $\mathrm{PO}_{4}$ ).

- Suspended sediment and volatile suspended solids-About 13 percent of total suspended sediment was volatile suspended solids. This percentage was independent of flow and suspended-sediment concentration.

- Total nitrogen and nitrate-The proportion of the $\mathrm{TN}$ that was $\mathrm{NO}_{3}$ was a function of flow. As flow increased, the ratio of $\mathrm{NO}_{3}$ to $\mathrm{TN}$ decreased. A relation between the logarithm of flow and the ratio of $\mathrm{NO}_{3}$ to $\mathrm{TN}$ was developed and used to compute daily $\mathrm{NO}_{3}$ concentrations from TN.

- Total nitrogen and ammonia-The proportion of the $\mathrm{TN}$ that was $\mathrm{NH}_{4}$ also was a function of flow. As flow increased, the ratio of $\mathrm{NH}_{4}$ to $\mathrm{TN}$ increased. A relation between the logarithm of flow and the ratio of $\mathrm{NH}_{4}$ to $\mathrm{TN}$ was developed and used to compute daily $\mathrm{NH}_{4}$ concentrations from TN.

- Total phosphorus and orthophosphorus-A relation between $\mathrm{TP}$ concentration and the ratio of $\mathrm{PO}_{4}$ to TP was developed and used to compute daily $\mathrm{PO}_{4}$ concentrations from TP. The ratio of TP to $\mathrm{PO}_{4}$ was not related to flow.

For the remaining constituents, iron concentrations were assumed to be constant at $0.15 \mathrm{mg} / \mathrm{L}$ based on data from other streams in the Piedmont (Jaynes, 1994); algal concentrations were assumed to be negligible at $0.01 \mathrm{mg} / \mathrm{L}$. Daily DO concentrations were interpolated from measurements of DO at site 07.

- Branch 4, Gar Creek: The water-chemistry boundary conditions for Gar Creek were generated in a manner similar to the McDowell Creek water-chemistry boundary conditions. Gar Creek loading equations for total suspended sediment, TN, TP, and BOD (Bales and others, 1999) were used with daily streamflow at site 33 to obtain daily loads, which were converted to daily mean concentrations by dividing the computed load by the daily mean streamflow.
Site-specific relations between (1) total suspended sediment and volatile suspended solids, (2) $\mathrm{TN}$ and $\mathrm{NO}_{3}$, (3) $\mathrm{TN}$ and $\mathrm{NH}_{4}$, and (4) $\mathrm{TP}$ and $\mathrm{PO}_{4}$ were developed from the Gar Creek data (Robinson, Hazell, and Garrett, 1998) and were applied to estimate daily mean concentrations of volatile suspended solids, $\mathrm{NO}_{3}, \mathrm{NH}_{4}$, and $\mathrm{PO}_{4}$. Iron concentrations were assumed to be constant at $0.15 \mathrm{mg} / \mathrm{L}$, algal concentrations were assumed to be minimal and constant at $0.01 \mathrm{mg} / \mathrm{L}$, and DO concentrations were interpolated from measurements of DO in Gar Creek cove at site 11.

- Branches 3 and 5, ungaged areas: Chemical loadings into these two coves were assumed to be negligible under 1996-97 conditions (table 9). The DO concentration of the inflow was assumed to be equal to the DO concentration in the cove.

- Riverbend ash settling pond discharge: Monthly values of total suspended solids, TN, TP, and iron were provided by the North Carolina DWQ as part of the compliance monitoring program (M.E. Lieber, North Carolina Division of Water Quality, written commun., September 1998). Particulate organic matter was assumed to be equal to one-half of the total suspended solids concentration, and $\mathrm{PO}_{4}$ was assumed to be equal to one-half of the TP concentration. All TN concentrations were reported as zero. The DO concentration in the discharge was assumed to be equal to the DO concentration in the lake, and BOD was assumed to be constant at $1 \mathrm{mg} / \mathrm{L}$.

- Riverbend Steam Station discharge: Riverbend Steam Station discharge water chemistry was assumed to be the same as water chemistry at the station intake, which is located very near site 04 (fig. 2), because the water is used only for cooling. Water-chemistry data measured at site 04 were used to describe the water chemistry of the Riverbend Steam Station discharge. At site 04, 17 sets of samples were collected between May 28, 1996, and September 9, 1997 (Sarver and Steiner, 1998).

- McDowell Creek WWTP discharge: Monthly values of total suspended solids, $\mathrm{NH}_{4}, \mathrm{TN}$, TP, DO, and BOD were provided by the North Carolina DWQ as part of the compliance 
monitoring program (M.E. Lieber, North Carolina Division of Water Quality, written commun., September 1998). Particulate organic matter concentration was assumed to be equal to 90 percent of the reported total suspended solids concentration. Nitrate concentration was assumed to be equal to one-half of the reported $\mathrm{TN}$ concentration, and $\mathrm{PO}_{4}$ concentration was assumed to be equal to 20 percent of the reported TP concentration. Iron concentration was assumed to be constant at $0.05 \mathrm{mg} / \mathrm{L}$, and algal concentration was assumed to be zero.

\section{Loads of Selected Constituents to Mountain Island Lake}

Total loads of suspended sediment (reported as total suspended solids for site 01, McDowell Creek WWTP, and the Riverbend discharge), $\mathrm{BOD}, \mathrm{NH}_{4}$, $\mathrm{NO}_{3}$, TN, and TP to Mountain Island Lake were estimated for the 1-year period May 1, 1996-April 30, 1997. Loads were estimated for (1) Cowans Ford Dam releases, (2) McDowell Creek, (3) Gar Creek, (4) McDowell Creek WWTP, and (5) the Riverbend ash settling pond discharge. The quality of the water in the Riverbend thermal discharge was assumed to be the same (or better) as the water quality at the withdrawal point, so no net change in loadings to the reservoir occurred as a result of the combined effects of the withdrawal and release. Only flow and water temperature were reported for the thermal discharge as part of the North Carolina DWQ compliance monitoring program (M.E. Lieber, North Carolina Division of Water Quality, written commun., September 1998).

Additional point-source discharges to Mountain Island Lake include the following:

- Two discharges from McGuire Nuclear Power Station, located on the shore of Lake Norman near Cowans Ford Dam. Combined average flow from these two discharges is $0.012 \mathrm{~m}^{3} / \mathrm{s}$, and the total suspended solids loading for May 1, 1996-April 30, 1997, was about 2,500 kilograms $(\mathrm{kg}$ ) (data from North Carolina DWQ compliance monitoring program; M.E. Lieber, North Carolina Division of Water Quality, written commun., September 1998).

- One discharge from the Charlotte-Mecklenburg Utilities North Mecklenburg Water Treatment Plant.
These three discharges were not included in the loading calculations because of the absence of nitrogen, phosphorus, and BOD data and because of the relatively small size of the discharges compared to the other inflows.

Loadings were computed in the following manner:

- Cowans Ford Dam-Hourly estimates of flow at Cowans Ford Dam and measurements of total suspended solids, $\mathrm{BOD}, \mathrm{NH}_{4}, \mathrm{NO}_{3}, \mathrm{TN}$, and TP at site 01 were used to estimate loads from Cowans Ford Dam. Hourly load estimates were summed to provide daily and monthly loads. For the purposes of the loading calculations, constituent concentrations at site 01 were assumed to remain constant between sample collections (fig. 23). All measured BOD concentrations were reported as less than $2 \mathrm{mg} / \mathrm{L}$ (Sarver and Steiner, 1998). As with the water-quality model boundary condition, BOD was assumed to be constant at $0.5 \mathrm{mg} / \mathrm{L}$. Several of the total ammonia plus organic nitrogen concentrations were reported as less than $0.20 \mathrm{mg} / \mathrm{L}$. These concentrations were assumed to be $0.1 \mathrm{mg} / \mathrm{L}$ and were used with measured $\mathrm{NO}_{3}$ concentrations to calculate $\mathrm{TN}$.

- Riverbend ash settling pond dischargeMonthly compliance monitoring data on flow, total suspended solids, and TP (M.E. Lieber, North Carolina Division of Water Quality, written commun., September 1998) were used to compute monthly loads.

- McDowell Creek and Gar Creek-Daily loads were estimated by using the loading equations (Bales and others, 1999) as previously described for the water-chemistry boundary conditions.

- McDowell Creek WWTP_Loads were computed from monthly values of flow, total suspended solids, $\mathrm{NH}_{4}, \mathrm{TN}$, TP, and BOD provided by the North Carolina DWQ as part of the compliance monitoring program (M.E. Lieber, North Carolina Division of Water Quality, written commun., September 1998). Nitrate concentration was assumed to be equal to one-half of the reported TN concentration.

As expected, Cowans Ford Dam releases were the greatest contributor of constituent loads to Mountain Island Lake (table 11). Daily mean flow at 
Table 11. Loads of total suspended solids, biochemical oxygen demand, nitrate, ammonia, total nitrogen, and total phosphorus to Mountain Island Lake during May 1, 1996-April 30, 1997

[WWTP, wastewater-treatment plant; BOD, biochemical oxygen demand; -, no data, but load is negligible]

\begin{tabular}{|c|c|c|c|c|c|c|}
\hline Constituent & $\begin{array}{l}\text { Cowans } \\
\text { Ford Dam }\end{array}$ & $\begin{array}{l}\text { Riverbend } \\
\text { ash settling } \\
\text { pond }\end{array}$ & $\begin{array}{c}\text { McDowell } \\
\text { Creek }\end{array}$ & Gar Creek & $\begin{array}{c}\text { McDowell } \\
\text { Creek } \\
\text { WWTP } \\
\end{array}$ & Total \\
\hline \multicolumn{7}{|c|}{ Load, in kilograms } \\
\hline Total suspended solids & $16,600,000$ & 32,000 & $21,800,000$ & $5,490,000$ & 41,600 & $43,963,600$ \\
\hline BOD & $1,124,000$ & - & 213,000 & 26,500 & 12,200 & $1,375,700$ \\
\hline Nitrate & 375,000 & - & 26,100 & 2,100 & 23,400 & 426,600 \\
\hline Ammonia & 71,810 & - & 6,000 & 1,200 & 600 & 79,610 \\
\hline Total nitrogen & 649,000 & - & 53,600 & 19,400 & 46,600 & 768,600 \\
\hline Total phosphorus & 14,100 & 760 & 26,400 & 2,400 & 7,420 & 51,080 \\
\hline \multicolumn{7}{|c|}{ Load, as percent of total } \\
\hline Total suspended solids & 37.8 & 0.1 & 49.6 & 12.5 & 0.1 & 100 \\
\hline BOD & 81.7 & - & 15.5 & 1.9 & .9 & 100 \\
\hline Nitrate & 87.9 & - & 6.1 & .5 & 5.5 & 100 \\
\hline Ammonia & 90.2 & - & 7.5 & 1.5 & .8 & 100 \\
\hline Total nitrogen & 84.4 & - & 7.0 & 2.5 & 6.1 & 100 \\
\hline Total phosphorus & 27.6 & 1.5 & 51.7 & 4.7 & 14.5 & 100 \\
\hline
\end{tabular}

Cowans Ford Dam during May 1996-April 1997 was about $71 \mathrm{~m}^{3} / \mathrm{s}$, whereas mean flow at the mouths of McDowell Creek and Gar Creek was about $1 \mathrm{~m}^{3} / \mathrm{s}$ and $0.15 \mathrm{~m}^{3} / \mathrm{s}$, respectively, during the same period. Flow from Cowans Ford Dam into Mountain Island Lake represents more than 85 percent of the total inflow to the lake (table 3), or more than 97 percent of the total inflow to the lake if the Riverbend Steam Station withdrawal and discharge are excluded from the water balance.

Both McDowell and Gar Creeks contributed a disproportionately large amount of total suspended solids to Mountain Island Lake. More suspended solids entered the reservoir by way of McDowell Creek as through Cowans Ford Dam, and yet the mean flow for McDowell Creek during May 1996-April 1997 was almost 100 times less than the flow at Cowans Ford Dam during the same period. Similarly, Gar Creek contributed about one-third as much total suspended solids to the reservoir as was released through Cowans Ford Dam, although Gar Creek mean flow was about 1,000 times less than the mean flow through Cowans Ford Dam.

As a result of the high solids loading from McDowell Creek, Secchi depths in McDowell Creek cove at site 07 were much less than at other sites in Mountain Island Lake and less than Secchi depths in
Rhodhiss Lake and Lake Hickory (table 12). The low light penetration along with the relatively short residence time of water in Mountain Island Lake probably act to reduce algal growth in McDowell Creek cove, despite somewhat elevated nutrient concentrations in the cove.

McDowell Creek and Gar Creek both contributed much more BOD to Mountain Island Lake than was released by the McDowell Creek WWTP (table 11). Loadings of TP and TN also were greater in McDowell Creek than in the WWTP discharge during May 1996-April 1997, although TN loadings from the treatment plant were very nearly the same as those in McDowell Creek. Previous reports suggest that the McDowell Creek WWTP was the largest contributor of nutrients to the McDowell Creek cove of Mountain Island Lake (Mecklenburg County Department of Environmental Protection, 1995; North Carolina Department of Environment and Natural Resources, 1999a), but these results indicate that nonpoint-source loadings in McDowell Creek exceeded point-source loadings from the McDowell Creek WWTP during 1996-97. Loadings of TP and TN from Gar Creek were less than one-half the loadings from the WWTP. The WWTP contributed one-sixth of the TP loadings to the reservoir during May 1996-April 1997 (table 11). 
Table 12. Secchi depths in Mountain Island Lake, Rhodhiss Lake, and Lake Hickory

[m, meter; MI, Mountain Island Lake; NC DWQ, North Carolina Division of Water Quality]

\begin{tabular}{lcccc}
\hline \multicolumn{1}{c}{ Location (data source) } & \multirow{2}{*}{$\begin{array}{c}\text { Study } \\
\text { period }\end{array}$} & $\begin{array}{c}\text { Number of } \\
\text { observations }\end{array}$ & \multicolumn{2}{c}{ Secchi depth (m) } \\
\cline { 5 - 6 } & $1996-97$ & 17 & Median & Range \\
\hline \hline MI site 07 (this study) & $1981-97$ & 8 & 0.6 & $0.2-1.6$ \\
MI site 07 (NC DWQ, 1998) & $1996-97$ & 17 & .8 & $0.7-1.1$ \\
MI site 09 (this study) & $1996-97$ & 17 & 1.3 & $0.2-2.2$ \\
MI site 14 (this study) & $1981-97$ & 8 & 1.6 & $0.4-2.6$ \\
MI site 14 (NC DWQ, 1998) & $1993-94$ & 21 & 1.75 & $1.3-2.1$ \\
Rhodhiss Lake-mid-lake (Jaynes, 1994) & $1993-94$ & 21 & .8 & $0.2-1.6$ \\
Lake Hickory-mid-lake (Jaynes, 1994) & & 1.1 & $0.6-1.6$ \\
\hline
\end{tabular}

The surface withdrawal of water from Lake Norman for release to Mountain Island Lake, along with the extremely long hydraulic retention time of water in Lake Norman (about 206 days; North Carolina Department of Environment, Health, and Natural Resources, 1992), contributes to the relatively low TP loads coming into Mountain Island Lake through Cowans Ford Dam. Phosphorus concentrations generally are low in the surface layers of Piedmont reservoirs, particularly at the downstream end of the reservoir, because phosphorus is used for algal production; whereas, phosphorus concentrations in near-bottom waters can be elevated during the summer because of phosphorus release from sediments during hypoxic conditions (for example, Giorgino and Bales, 1997; Bales and Giorgino, 1998). The long residence times in Lake Norman provide greater opportunity for algal production and phosphorus uptake. Some of the most recent (June 1997) measurements in Lake Norman confirm these general trends (North Carolina Department of Environment and Natural Resources, 1998a). Both chlorophyll $a$ (range of 10 to $21 \mu \mathrm{g} / \mathrm{L}$ ) and phosphorus concentrations were highest at the upstreammost sampling location in the lake. For the period 1981-97, median chlorophyll $a$ concentrations (about $3 \mu \mathrm{g} / \mathrm{L}$ ) were lowest near Cowans Ford Dam, and most of the measured TP concentrations were at or less than the detection limit of $0.01 \mathrm{mg} / \mathrm{L}$.

Total nitrogen and total phosphorus loadings to Mountain Island Lake from McDowell and Gar Creeks were highly intermittent and occurred during high-flow events (fig. 24). In fact, about half of the TP load from McDowell Creek during May 1, 1996-April 30, 1997 (table 11), occurred during only 7 of the 365 days of that period. The greatest daily load of TP and TN from McDowell and Gar Creeks during the entire study period occurred during a storm July 22-23, 1997 (fig. 24), which resulted in greater than 100-year flooding in parts of Charlotte (Robinson, Hazell, and Young, 1998). During low-flow periods, daily loads of TN and TP from the McDowell Creek WWTP plant exceeded daily loads from Gar and McDowell Creeks (fig. 24). Daily nitrogen loads from Cowans Ford Dam almost always exceeded daily nitrogen loads from all other sources (fig. 24B).

Following completion of data collection for this study, the capacity of the McDowell Creek WWTP was expanded; a biological nutrient removal system was added, and more stringent limits were placed in the plant's discharge permit. Although the discharge from the plant almost doubled from about $0.1 \mathrm{~m}^{3} / \mathrm{s}$ during 1996-97 to slightly more than $0.2 \mathrm{~m}^{3} / \mathrm{s}$ during 1999-2000, loadings of total suspended solids, BOD, $\mathrm{TN}$, and TP, were reduced greatly (table 13) over the same period (M.E. Lieber, North Carolina Division of Water Quality, written commun., August 2000). As a result, assuming that the export from all sources other than the WWTP were the same during 1999-2000 as during 1996-97, the WWTP now contributes less than 5 percent of the TP loading to the reservoir, and contributions from nonpoint sources (primarily McDowell Creek) may account for more than half of the TP loading to Mountain Island Lake.

Release of $\mathrm{PO}_{4}$ and $\mathrm{NH}_{4}$ from bottom sediments to the overlying water in Mountain Island Lake, or internal loads, likely were low. Orthophosphorus and $\mathrm{NH}_{4}$ releases from near-bottom sediments generally occur during low DO conditions-usually at concentrations less than $0.5 \mathrm{mg} / \mathrm{L}$. Because nearbottom water $\mathrm{DO}$ concentrations seldom were less than $5 \mathrm{mg} / \mathrm{L}$ (fig. 12), internal loadings of $\mathrm{PO}_{4}$ and $\mathrm{NH}_{4}$ probably are insignificant relative to external loads. 

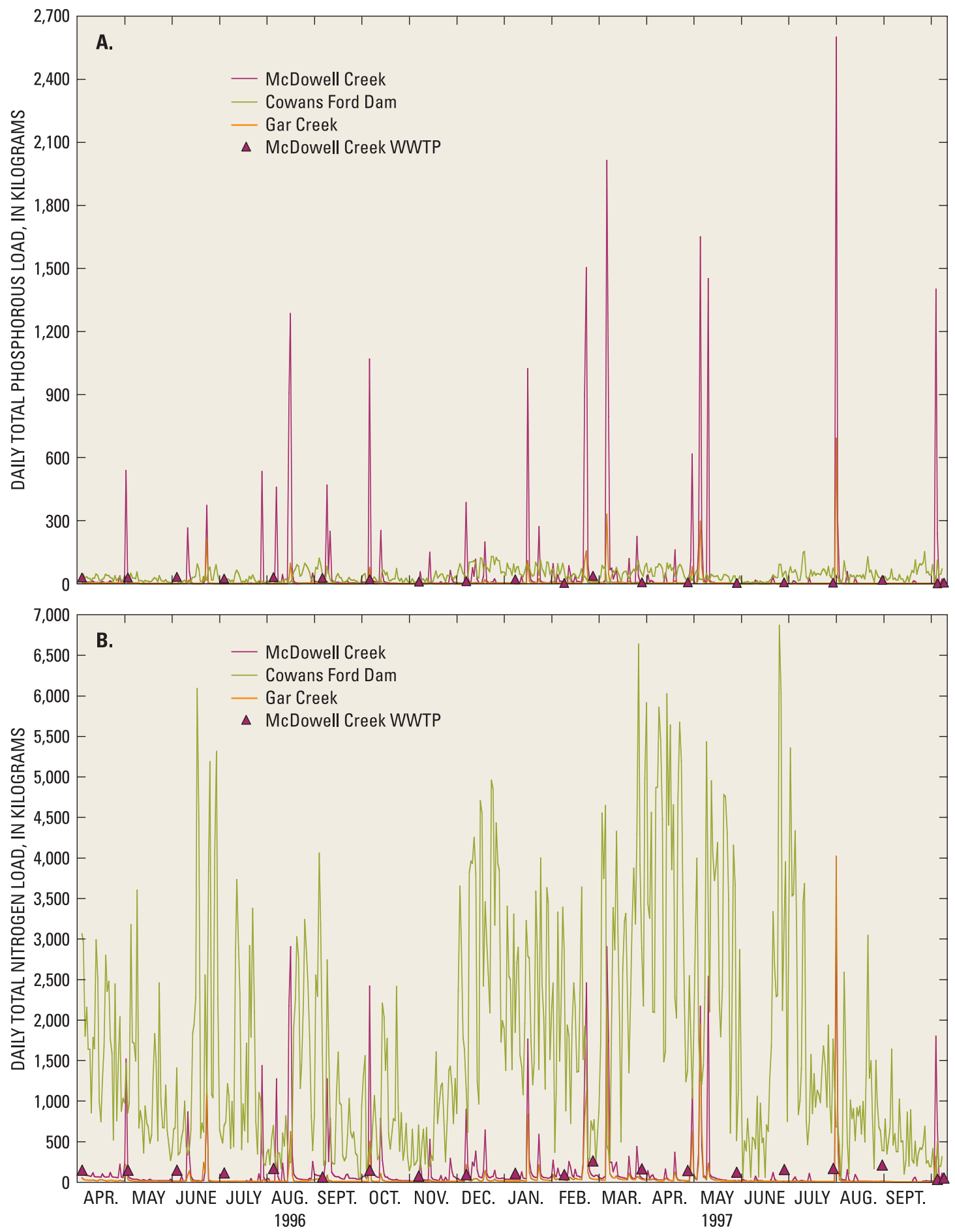

Figure 24. Daily export of (A) total phosphorus and (B) total nitrogen from McDowell Creek, Cowans Ford Dam, Gar Creek, and McDowell Creek Wastewater-Treatment Plant to Mountain Island Lake for April 2, 1996-September 29, 1997. 
Table 13. Loads of total suspended solids, biochemical oxygen demand, total nitrogen, and total phosphorus to Mountain Island Lake from McDowell Creek WastewaterTreatment Plant during May 1, 1996-April 30, 1997, and May 1, 1999-April 30, 2000 [BOD, biochemical oxygen demand]

\begin{tabular}{|c|c|c|c|c|}
\hline \multirow[t]{2}{*}{ Constituent } & \multicolumn{2}{|c|}{$\begin{array}{c}\text { Load } \\
\text { (kilograms) }\end{array}$} & \multicolumn{2}{|c|}{$\begin{array}{c}\text { Load } \\
\text { (percent of total to } \\
\text { Mountain Island Lake) }\end{array}$} \\
\hline & 1996-97 & 1999-2000 & 1996-97 & $1999-2000^{a}$ \\
\hline Total suspended solids & 41,600 & 4,740 & 0.1 & $\overline{0.01}$ \\
\hline BOD & 12,200 & 3,710 & .9 & .3 \\
\hline Total nitrogen & 46,600 & 37,500 & 6.1 & 4.9 \\
\hline Total phosphorus & 7,420 & 1,350 & 14.5 & 2.6 \\
\hline
\end{tabular}

${ }^{a}$ Calculated by assuming that all inputs to Mountain Island Lake were the same in 1996-97 as in 1999-2000, with the exception of the wastewater-treatment plant discharge.

\section{Meteorological Conditions}

Meteorological data are required to compute wind stress and heat exchange at the surface of the reservoir. Meteorological data included air temperature, dewpoint temperature, wind speed, wind direction, and percentage of cloud cover estimated from qualitative descriptions of sky conditions. Data were recorded at hourly intervals at the Charlotte/ Douglas International Airport, located about $15 \mathrm{~km}$ south of Mountain Island Dam, and provided by the National Climatic Data Center in Asheville, N.C. Numerous periods of missing record usually were limited to an hour or two of missing observations per day. Essentially no meteorological data were available for the period July 22-August 20, 1996; other periods of missing record also include February 24-25, 1997, and June 25-26, 1997. Estimates for periods of missing data were determined by linear interpolation between the recorded values.

\section{Model Calibration and Testing}

The Mountain Island Lake water-quality model was calibrated by adjusting the computational grid, model parameters, and in some cases, estimated boundary data for the period April 18, 1996September 30, 1997. The calibration sequence was (1) water balance, (2) water temperature, and (3) water chemistry.

\section{Water Balance}

After a satisfactory computational grid was developed, inflows to Mountain Island Lake from
Cowans Ford Dam were adjusted to achieve agreement between measured and simulated water levels as a measure of the water balance. Some errors likely occurred in the computational grid representation of the bathymetry as well as in all estimates of inflow to and outflow from the reservoir. For some reservoir models, all of these errors are assumed to be associated with ungaged tributary inflow to the reservoir. Most of the tributary inflow to Mountain Island Lake is measured, however, and because of the small intervening drainage area, tributary flows are quite small relative to flows through the upstream and downstream dams. Consequently, for this application, all of the errors associated with the water balance were assumed to be in the Cowans Ford Dam flows, and these flows were adjusted to close the water balance. The average adjustment for all inflow values was a negative 4 percent; the best measures of streamflow typically are assumed to be accurate within plus or minus $( \pm) 5$ percent. As previously described, rainfall on the reservoir and evaporation from the reservoir are not included in the water balance. Rainfall and evaporation are the smallest two contributors to the water balance, and rainfall additions are very nearly balanced by evaporative losses (table 3 ).

The calibrated values of the hydraulic and thermal parameters (table 14) used in the Mountain Island Lake water-quality model were the same as those used in the Rhodhiss Lake (Giorgino and Bales, 1997) and Lake Hickory (Bales and Giorgino, 1998) water-quality models, with the exception of the temperature of the bottom material. A value of $15^{\circ} \mathrm{C}$ was used in the Rhodhiss Lake and Lake Hickory models; however, the heat exchange at the bottom of 
Table 14. Hydraulic and thermal parameters in the calibrated Mountain Island Lake water-quality model

$\left[\mathrm{m}^{0.5} / \mathrm{s}\right.$, meter to the half power per second; $\left(\right.$ watts $\left./ \mathrm{m}^{2}\right) /{ }^{\circ} \mathrm{C}$, watts per square meter per degree Celsius; ${ }^{\circ} \mathrm{C}$, degree Celsius; $\mathrm{m}^{2} / \mathrm{s}$, square meter per second; $\mathrm{m}$, meter; $\left(\mathrm{m}^{3} / \mathrm{m}\right) / \mathrm{g}$, cubic meter per meter per gram]

\begin{tabular}{|c|c|c|c|}
\hline Parameter & Purpose & Calibrated value & $\begin{array}{c}\text { Constant or time } \\
\text { variable }\end{array}$ \\
\hline Chezy resistance coefficient & $\begin{array}{l}\text { Represent turbulent exchange of energy at } \\
\text { reservoir bottom }\end{array}$ & $70 \mathrm{~m}^{0.5} / \mathrm{s}$ & Constant \\
\hline $\begin{array}{l}\text { Coefficient of sediment-water } \\
\text { heat exchange }\end{array}$ & $\begin{array}{l}\text { Compute heat exchange between reservoir } \\
\text { bottom and overlying water }\end{array}$ & $7 \times 10^{-8}\left(\right.$ watts $\left./ \mathrm{m}^{2}\right) /{ }^{\circ} \mathrm{C}$ & Constant \\
\hline Temperature of bottom material & $\begin{array}{l}\text { Compute heat exchange between reservoir } \\
\text { bottom and overlying water }\end{array}$ & $18^{\circ} \mathrm{C}$ & Constant \\
\hline Wind sheltering coefficient & $\begin{array}{l}\text { Reduce measured wind speed to effective } \\
\text { wind speed at water surface }\end{array}$ & $\begin{array}{c}0.80 \\
\text { (dimensionless) }\end{array}$ & $\begin{array}{l}\text { Time variable } \\
\text { (constant in this } \\
\text { application) }\end{array}$ \\
\hline Longitudinal eddy viscosity & $\begin{array}{l}\text { Represent laterally averaged longitudinal } \\
\text { turbulent transport of momentum }\end{array}$ & $1 \mathrm{~m}^{2} / \mathrm{s}$ & Constant \\
\hline Longitudinal eddy diffusivity & $\begin{array}{l}\text { Represent laterally averaged longitudinal } \\
\text { turbulent transport of mass and heat }\end{array}$ & $1 \mathrm{~m}^{2} / \mathrm{s}$ & Constant \\
\hline $\begin{array}{l}\text { Light extinction coefficient for } \\
\text { water }\end{array}$ & $\begin{array}{l}\text { Calculate amount of solar radiation absorbed } \\
\text { in the surface layer }\end{array}$ & $0.45 / \mathrm{m}$ & Constant \\
\hline $\begin{array}{l}\text { Light extinction coefficient for } \\
\text { organic solids }\end{array}$ & $\begin{array}{l}\text { Calculate amount of solar radiation absorbed } \\
\text { in the surface layer }\end{array}$ & $0.2\left(\mathrm{~m}^{3} / \mathrm{m}\right) / \mathrm{g}$ & Constant \\
\hline $\begin{array}{l}\text { Fraction of incident solar radia- } \\
\text { tion absorbed at water surface }\end{array}$ & $\begin{array}{l}\text { Calculate amount of solar radiation absorbed } \\
\text { in the surface layer }\end{array}$ & $\begin{array}{c}0.45 \\
\text { (dimensionless) }\end{array}$ & Constant \\
\hline
\end{tabular}

the reservoir is about two orders of magnitude less than the surface heat exchange.

Measured water levels were in good agreement with simulated water levels (site 14, fig. 25). The mean difference between measured and simulated water levels was $0.001 \mathrm{~m}$, and the root-mean-square difference was $0.058 \mathrm{~m}$. Sixty-nine percent of the errors were within $\pm 0.05 \mathrm{~m}$, and 91.7 percent of the errors were within $\pm 0.1 \mathrm{~m}$.

\section{Temperature}

The effects of inflow water temperature, surface heat exchange (which includes the effects of solar radiation and wind), bottom heat exchange, transport of heat, internal mixing (including the effects of the withdrawal at Mountain Island Dam), and solids concentration are included in the simulation of water temperature. Surface heat exchange is computed from latitude and longitude, hourly records of air temperature, dewpoint temperature, cloud cover, wind speed and direction, and the simulated surface-water temperature. Although evaporation is not simulated in this application (see previous section), the loss of heat from the reservoir resulting from evaporation is included in the heat balance. Solids in the water column affect light penetration and, consequently, heat distribution in the reservoir.

Calibrated model parameters used for the simulation of water temperature in Mountain Island Lake (table 14) are very similar to those used for the simulation of water temperature in Rhodhiss Lake and Lake Hickory (Giorgino and Bales, 1997; Bales and Giorgino, 1998). Cloud cover data, which are reported by the National Weather Service as a qualitative measure ("sunny," "mostly cloudy," and so on) and then converted to a value between 0 and 10 , were adjusted (40 percent) to increase the amount of solar radiation in order to obtain good agreement between measured and simulated water temperatures.

Time series of near-surface and near-bottom measured and simulated water temperatures were compared at site 14 (model segment 33). The mean difference between measured and simulated values was about $0.2^{\circ} \mathrm{C}$ for both the near-surface and near-bottom sensors, and the root-mean-square difference was about $1{ }^{\circ} \mathrm{C}$ at both locations (table 15). Simulations of temperature were more accurate near the bottom than near the surface (fig. 26), where daily fluctuations in temperature were large as a result of solar heating and thermal discharge near the measurement site. 


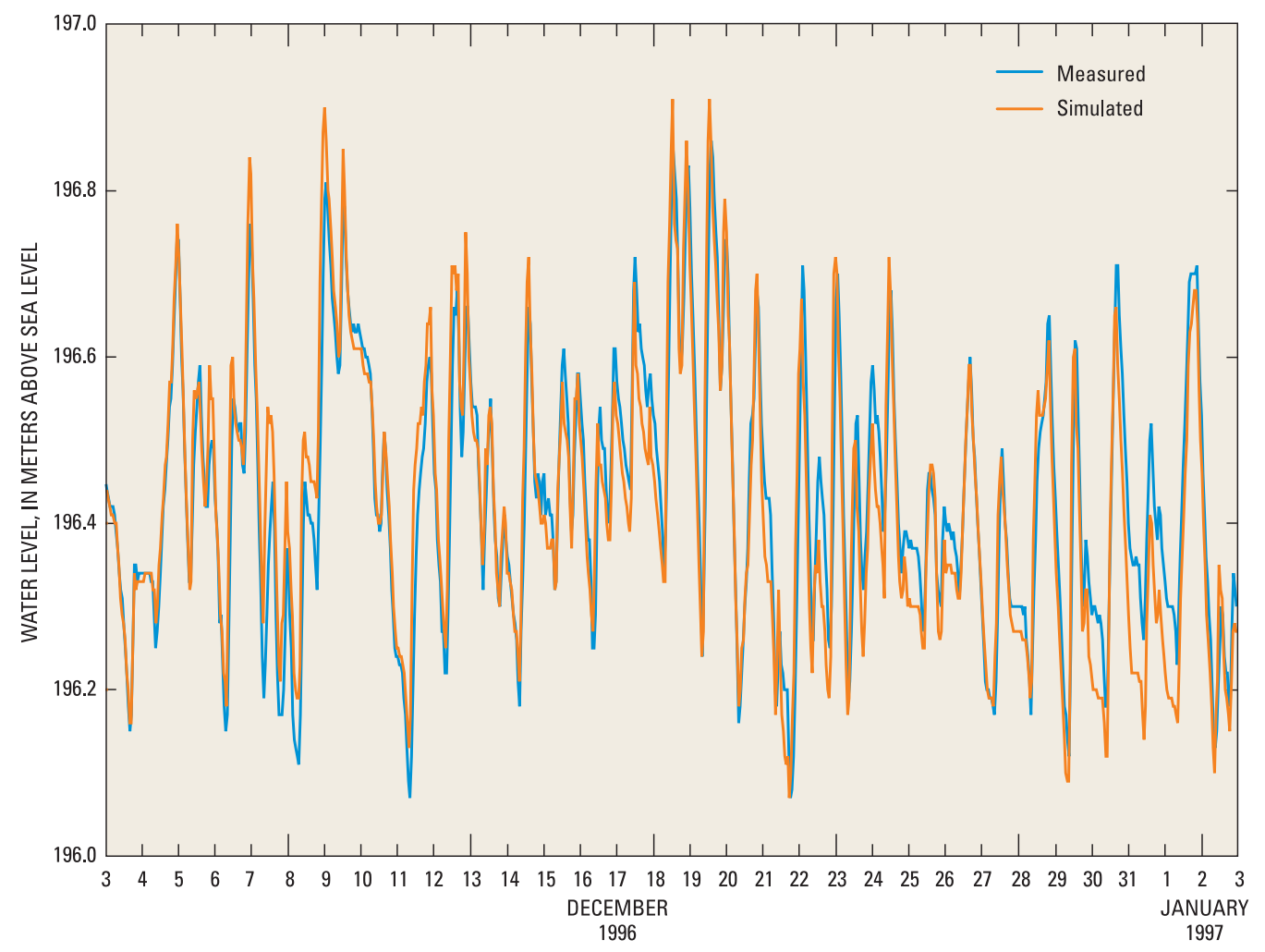

Figure 25. Measured and simulated water level at Mountain Island Lake site 14, December 3 , 1996-January 3, 1997.

Table 15. Comparison of measured and simulated water temperature for selected Mountain Island Lake sites $\left[{ }^{\circ} \mathrm{C}\right.$, degree Celsius; RMS, root mean square difference; >, greater than; \pm , plus or minus]

\begin{tabular}{|c|c|c|c|c|c|c|c|c|}
\hline \multirow{3}{*}{$\begin{array}{l}\text { Site } \\
\text { (fig. 2) }\end{array}$} & \multirow{3}{*}{$\begin{array}{c}\text { Measurement } \\
\text { type } \\
\text { (location) }\end{array}$} & \multirow{3}{*}{$\begin{array}{c}\begin{array}{c}\text { Number } \\
\text { of } \\
\text { observations }\end{array}\end{array}$} & \multicolumn{6}{|c|}{$\begin{array}{l}\text { Difference between measured and simulated } \\
\text { water-temperature values }\end{array}$} \\
\hline & & & \multirow{2}{*}{$\begin{array}{c}\text { Mean } \\
\left({ }^{\circ} \mathrm{C}\right)\end{array}$} & \multirow{2}{*}{$\begin{array}{c}\text { Median } \\
\left({ }^{\circ} \mathrm{C}\right)\end{array}$} & \multirow{2}{*}{$\begin{array}{l}\text { RMS } \\
\left({ }^{\circ} \mathrm{C}\right)\end{array}$} & \multicolumn{3}{|c|}{ Percent of difference } \\
\hline & & & & & & $>0{ }^{\circ} \mathrm{C}$ & $\begin{array}{c}\text { within } \\
\pm 0.5^{\circ} \mathrm{C}\end{array}$ & $\begin{array}{r}\text { within } \\
\pm 1.0^{\circ} \mathrm{C}\end{array}$ \\
\hline $\bar{~} 14$ & $\begin{array}{l}\text { Time series } \\
\text { (near surface) }\end{array}$ & 12,787 & $\overline{-0.8}$ & $\overline{c-0.6}$ & $\overline{c 1.6}$ & $\overline{59}$ & 31 & $\bar{~} 58$ \\
\hline 14 & $\begin{array}{l}\text { Time series } \\
\text { (near bottom) }\end{array}$ & 12,193 & .3 & .4 & .7 & 74 & 48 & 85 \\
\hline 08 & $\begin{array}{l}\text { Profile } \\
\text { (mainstem) }\end{array}$ & 131 & -.7 & -.4 & 1.2 & 35 & 47 & 57 \\
\hline 09 & $\begin{array}{l}\text { Profile } \\
\text { (mainstem) }\end{array}$ & 241 & -.3 & -.2 & 1.1 & 40 & 39 & 65 \\
\hline 15 & $\begin{array}{l}\text { Profile } \\
\text { (mainstem) }\end{array}$ & 385 & .5 & .5 & 1.2 & 69 & 39 & 70 \\
\hline 07 & $\begin{array}{l}\text { Profile } \\
\text { (cove) }\end{array}$ & 94 & -.7 & -.5 & 1.2 & 28 & 41 & 66 \\
\hline 11 & $\begin{array}{l}\text { Profile } \\
\text { (cove) }\end{array}$ & 97 & -.6 & -.5 & 1.3 & 36 & 25 & 59 \\
\hline 13 & $\begin{array}{l}\text { Profile } \\
\text { (cove) }\end{array}$ & 160 & -.1 & -.1 & .9 & 44 & 39 & 74 \\
\hline
\end{tabular}




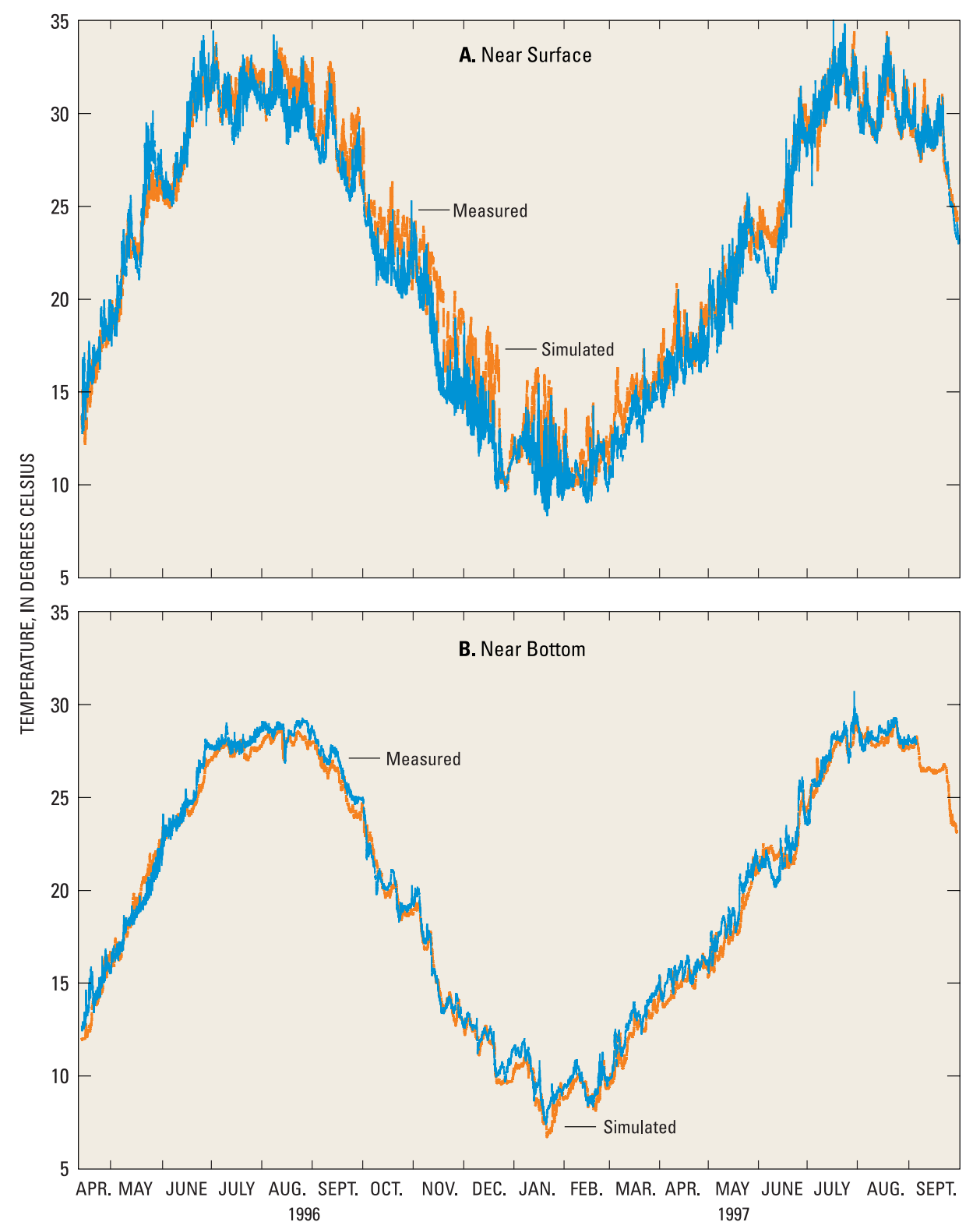

Figure 26. Measured and simulated $(A)$ near-surface and (B) near-bottom water temperature at Mountain Island Lake site 14, April 1996-September 1997.

Simulated vertical profiles of water temperature were compared with all available measured profiles for mainstem sites 08 (segment 20 at the mouth of McDowell Creek), 09 (segment 25), and 15 (segment 37 near Mountain Island Dam; fig. 27), and for cove sites 07 (segment 41, McDowell Creek cove), 11 (segment 52, Gar Creek cove), and 13 (segment 58). A total of 23 measured and simulated vertical profiles of water temperature were compared at each of these sites.
The error statistics for the simulated vertical profiles of water temperature were about the same as those for the simulated time series (table 15), with median differences between measured and simulated values on the order of $\pm 0.5^{\circ} \mathrm{C}$ and root-mean-square differences on the order of $1{ }^{\circ} \mathrm{C}$ (table 15). Vertical distributions of water temperature were simulated equally well in the mainstem of the reservoir and in the coves (table 15). There was a bias toward underprediction of water temperature at all sites except 
Site 08
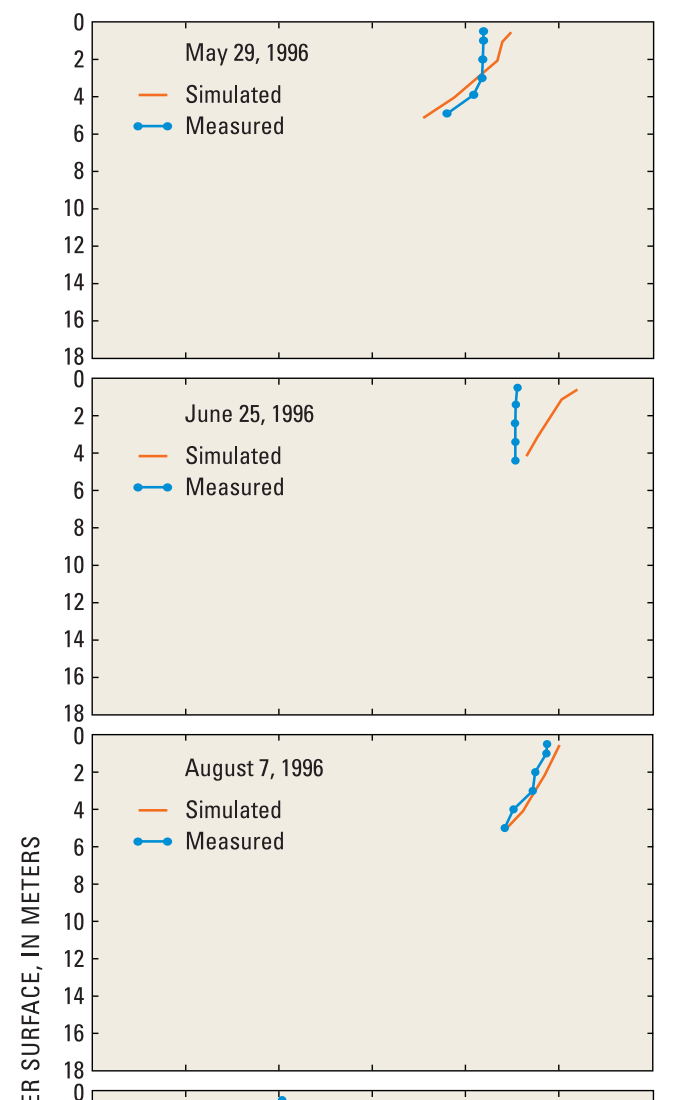

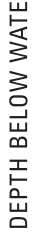
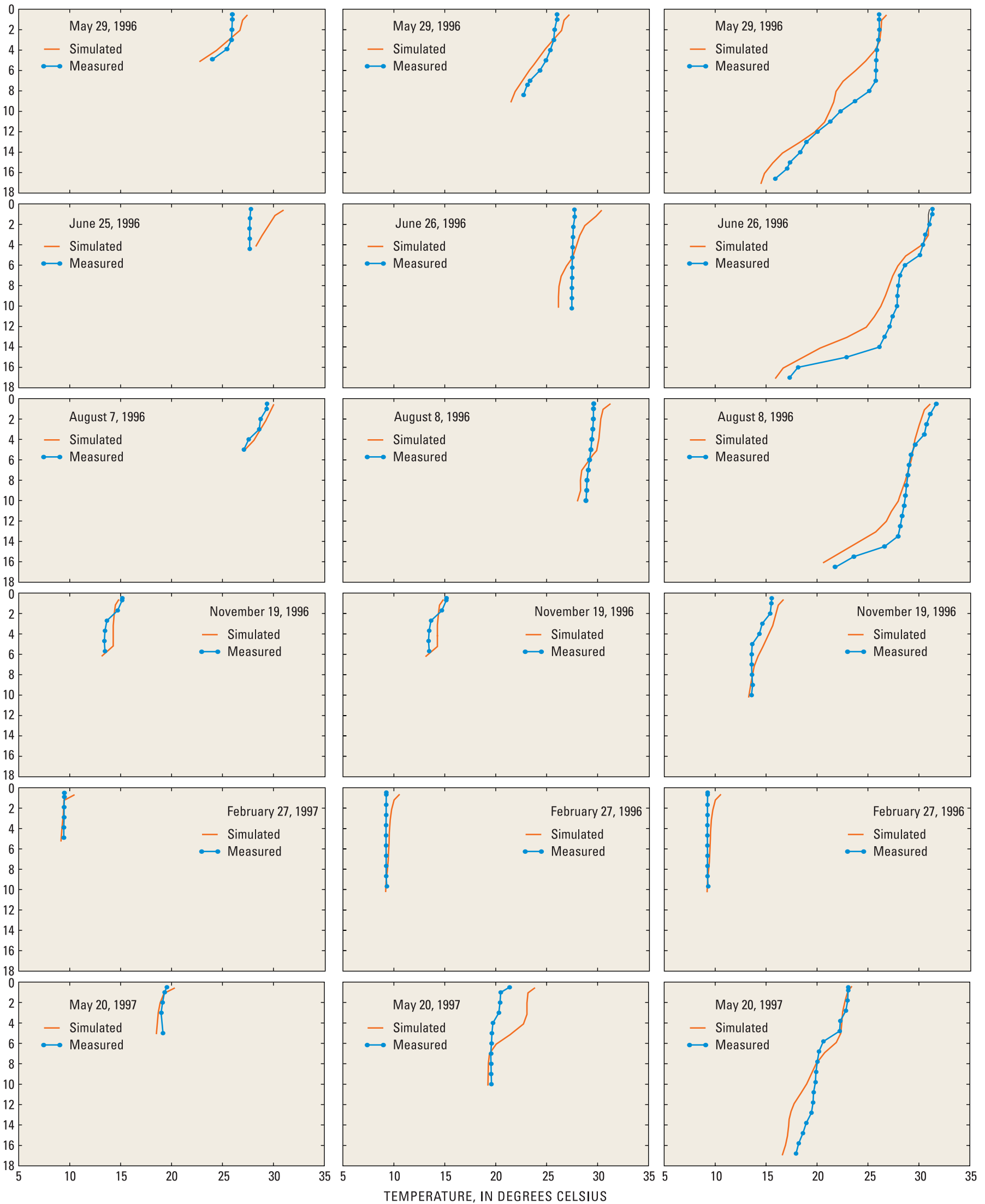

Figure 27. Measured and simulated vertical distributions of water temperature at three mainstem locations in Mountain Island Lake for six sets of measurements between May 1996 and May 1997. 
sites 14 and 15, which are downstream from the Riverbend thermal discharge.

\section{Water Chemistry and Dissolved Oxygen}

Water chemistry was calibrated by adjusting model parameters (table 16) to achieve satisfactory agreement between measured and simulated $\mathrm{NO}_{3}, \mathrm{NH}_{4}$, $\mathrm{PO}_{4}$, algal biomass (as measured by chlorophyll $a$ ), and DO. Calibrated model parameters for the Mountain Island Lake water-quality model generally were similar to those used in the Rhodhiss Lake (Giorgino and Bales, 1997) and Lake Hickory (Bales and Giorgino, 1998) models (table 16).

Simulations of chemical constituent concentrations in a reservoir are highly interrelated and are dependent on accurate estimates of chemical loads and simulations of flow and water temperature.

Moreover, despite the relative wealth of data available for this study, comparison of a few measurements of water chemistry taken instantaneously at a single point with a continuous simulation of water chemistry for a large mass of water is problematic. Improved point-bypoint agreement between measurements and simulations could be obtained by adjusting inflows, outflows, and loads and by setting model parameters to values beyond the range typically used. Such a model, however, would be considered "overtuned" and likely would be useful only for application to conditions for which the model was calibrated. Accurate simulations of DO and chlorophyll $a$ concentrations were emphasized in the water-chemistry simulations because North Carolina ambient water-quality standards have been established for these two constituents (North Carolina Department of Environment, Health, and Natural Resources, 1997); however, results from simulations of $\mathrm{NO}_{3}, \mathrm{NH}_{4}$, and $\mathrm{PO}_{4}$ also are presented.

Table 16. Rate coefficients used in water-chemistry simulations for Mountain Island Lake

$\left[\mathrm{m} / \mathrm{d}\right.$; meter per day; watts $/ \mathrm{m}^{2}$, watts per square meter; ${ }^{\circ} \mathrm{C}$, degree Celsius; $\left(\mathrm{g} / \mathrm{m}^{2}\right) / \mathrm{d}$, gram per square meter per day; BOD, biochemical oxygen demand; $\mathrm{g} / \mathrm{m}^{3}$, gram per cubic meter; $\mathrm{mg} / \mathrm{L}$, milligram per liter]

\begin{tabular}{|c|c|c|c|}
\hline Parameter & Purpose & $\begin{array}{c}\text { Calibrated value in } \\
\text { Mountain Island } \\
\text { Lake model }\end{array}$ & $\begin{array}{l}\text { Calibrated values in } \\
\text { Rhodhiss Lake and } \\
\text { Lake Hickory models }\end{array}$ \\
\hline$\overline{\text { Suspended solids settling rate }}$ & $\begin{array}{l}\text { Compute settling rates and sediment } \\
\text { accumulation on bottom }\end{array}$ & $3.0 \mathrm{~m} / \mathrm{d}$ & $1-2 \mathrm{~m} / \mathrm{d}$ \\
\hline Algal growth rate & $\begin{array}{l}\text { Maximum gross algal production rate, } \\
\text { uncorrected for respiration, mortality, } \\
\text { excretion, or settling; temperature } \\
\text { dependent }\end{array}$ & $1.37 / \mathrm{d}$ & $1.2 /$ day $-1.9 / \mathrm{d}$ \\
\hline Algal mortality rate & $\begin{array}{l}\text { Maximum algal mortality rate; } \\
\text { temperature dependent }\end{array}$ & $0.1 / \mathrm{d}$ & $0.075 / \mathrm{d}-0.09 / \mathrm{d}$ \\
\hline Algal excretion rate & $\begin{array}{l}\text { Maximum algal photorespiration rate, } \\
\text { which becomes labile dissolved } \\
\text { organic matter. }\end{array}$ & $0.010 / \mathrm{d}$ & $0.005 / \mathrm{d}-0.010 / \mathrm{d}$ \\
\hline Algal dark respiration rate & Maximum algal dark respiration rate. & $0.05 / \mathrm{d}$ & $0.005 / \mathrm{d}-0.010 / \mathrm{d}$ \\
\hline Algal settling rate & $\begin{array}{l}\text { Represents settling velocity for algal } \\
\text { assemblages }\end{array}$ & $0.4 \mathrm{~m} / \mathrm{d}$ & $0.1 \mathrm{~m} / \mathrm{d}-0.2 \mathrm{~m} / \mathrm{d}$ \\
\hline Saturation light intensity & $\begin{array}{l}\text { Represents saturation light intensity at } \\
\text { maximum algal photosynthesis rate }\end{array}$ & 120 watts $/ \mathrm{m}^{2}$ & 150 watts $/ \mathrm{m}^{2}$ \\
\hline $\begin{array}{l}\text { Fraction of algal biomass lost by } \\
\text { mortality to detritus }\end{array}$ & $\begin{array}{l}\text { Calculate detritus and dissolved organic } \\
\text { matter concentrations; remaining } \\
\text { biomass becomes labile dissolved } \\
\text { organic matter }\end{array}$ & $\begin{array}{c}0.8 \\
\text { (dimensionless) }\end{array}$ & $\begin{array}{c}0.8 \\
\text { (dimensionless) }\end{array}$ \\
\hline Lower temperature for algal growth & $\begin{array}{l}\text { Determines effects of temperature on } \\
\text { algal growth rates }\end{array}$ & $19^{\circ} \mathrm{C}$ & $8^{\circ} \mathrm{C}-10{ }^{\circ} \mathrm{C}$ \\
\hline $\begin{array}{l}\text { Fraction of algal growth at lower } \\
\text { temperature }\end{array}$ & $\begin{array}{l}\text { Determines effects of temperature on } \\
\text { algal growth rates }\end{array}$ & $\begin{array}{c}0.15 \\
\text { (dimensionless) }\end{array}$ & $\begin{array}{c}0.1-0.2 \\
\text { (dimensionless) }\end{array}$ \\
\hline $\begin{array}{l}\text { Lower temperature for maximum algal } \\
\text { growth }\end{array}$ & $\begin{array}{l}\text { Determines effects of temperature on } \\
\text { algal growth rates }\end{array}$ & $30^{\circ} \mathrm{C}$ & $22{ }^{\circ} \mathrm{C}-24{ }^{\circ} \mathrm{C}$ \\
\hline
\end{tabular}


Table 16. Rate coefficients used in water-chemistry simulations for Mountain Island Lake-Continued

$\left[\mathrm{m} / \mathrm{d}\right.$; meter per day; watts $/ \mathrm{m}^{2}$, watts per square meter; ${ }^{\circ} \mathrm{C}$, degree Celsius; $\left(\mathrm{g} / \mathrm{m}^{2}\right) / \mathrm{d}$, gram per square meter per day; BOD, biochemical oxygen demand; $\mathrm{g} / \mathrm{m}^{3}$, gram per cubic meter; $\mathrm{mg} / \mathrm{L}$, milligram per liter]

\begin{tabular}{|c|c|c|c|}
\hline Parameter & Purpose & $\begin{array}{c}\text { Calibrated value in } \\
\text { Mountain Island } \\
\text { Lake model }\end{array}$ & $\begin{array}{l}\text { Calibrated values in } \\
\text { Rhodhiss Lake and } \\
\text { Lake Hickory models }\end{array}$ \\
\hline $\begin{array}{l}\text { Fraction of maximum growth at lower } \\
\text { temperature }\end{array}$ & $\begin{array}{l}\text { Determines effects of temperature on } \\
\text { algal growth rates }\end{array}$ & $\begin{array}{c}0.99 \\
\text { (dimensionless) }\end{array}$ & $\begin{array}{c}0.99 \\
\text { (dimensionless) }\end{array}$ \\
\hline $\begin{array}{l}\text { Upper temperature for maximum algal } \\
\text { growth }\end{array}$ & $\begin{array}{l}\text { Determines effects of temperature on } \\
\text { algal growth rates }\end{array}$ & $35.1{ }^{\circ} \mathrm{C}$ & $22.5{ }^{\circ} \mathrm{C}-30.1{ }^{\circ} \mathrm{C}$ \\
\hline $\begin{array}{l}\text { Fraction of maximum growth at upper } \\
\text { temperature }\end{array}$ & $\begin{array}{l}\text { Determines effects of temperature on } \\
\text { algal growth rates }\end{array}$ & $\begin{array}{c}0.95 \\
\text { (dimensionless) }\end{array}$ & $\begin{array}{c}0.95 \\
\text { (dimensionless) }\end{array}$ \\
\hline Upper temperature for algal growth & $\begin{array}{l}\text { Determines effects of temperature on } \\
\text { algal growth rates }\end{array}$ & $36^{\circ} \mathrm{C}$ & $35^{\circ} \mathrm{C}$ \\
\hline $\begin{array}{l}\text { Fraction of algal growth at upper } \\
\text { temperature }\end{array}$ & $\begin{array}{l}\text { Determines effects of temperature on } \\
\text { algal growth rates }\end{array}$ & $\begin{array}{c}0.2 \\
\text { (dimensionless) }\end{array}$ & $\begin{array}{c}0.1 \\
\text { (dimensionless) }\end{array}$ \\
\hline $\begin{array}{l}\text { Labile dissolved organic matter decay } \\
\text { rate }\end{array}$ & $\begin{array}{l}\text { Compute dissolved-oxygen loss and } \\
\text { production of inorganic carbon, } \\
\text { ammonium, and phosphate from algal } \\
\text { decay; temperature dependent }\end{array}$ & $0.02 / \mathrm{d}$ & $0.04 / \mathrm{d}-0.09 / \mathrm{d}$ \\
\hline Labile to refractory decay rate & $\begin{array}{l}\text { Transfers labile to refractory dissolved } \\
\text { organic matter }\end{array}$ & $0.002 / \mathrm{d}$ & $0.002 / \mathrm{d}-0.005 / \mathrm{d}$ \\
\hline $\begin{array}{l}\text { Maximum refractory dissolved organic } \\
\text { matter decay rate }\end{array}$ & $\begin{array}{l}\text { Compute dissolved-oxygen loss and } \\
\text { production of inorganic carbon, } \\
\text { ammonium, and phosphate from decay } \\
\text { of refractory dissolved organic matter; } \\
\text { temperature dependent }\end{array}$ & $0.0002 / \mathrm{d}$ & $0.001 / \mathrm{d}$ \\
\hline Detritus decay rate & $\begin{array}{l}\text { Compute dissolved-oxygen loss and } \\
\text { production of inorganic carbon, } \\
\text { ammonium, and phosphate from decay } \\
\text { particulate organic matter; temperature } \\
\text { dependent }\end{array}$ & $0.005 / \mathrm{d}$ & $0.002 / \mathrm{d}-0.010 / \mathrm{d}$ \\
\hline Detritus settling velocity & $\begin{array}{l}\text { Compute loss of particulate organic } \\
\text { matter to bottom sediment }\end{array}$ & $0.8 \mathrm{~m} / \mathrm{d}$ & $1.0 \mathrm{~m} / \mathrm{day}-2.5 \mathrm{~m} / \mathrm{d}$ \\
\hline $\begin{array}{l}\text { Lower temperature for organic matter } \\
\text { decay }\end{array}$ & $\begin{array}{l}\text { Determines effects of temperature on } \\
\text { organic matter decay }\end{array}$ & $5^{\circ} \mathrm{C}$ & $5^{\circ} \mathrm{C}$ \\
\hline $\begin{array}{l}\text { Fraction of organic matter decay at } \\
\text { lower temperature }\end{array}$ & $\begin{array}{l}\text { Determines effects of temperature on } \\
\text { organic matter decay }\end{array}$ & 0.05 & 0.05 \\
\hline $\begin{array}{l}\text { Lower temperature for maximum } \\
\text { organic matter decay }\end{array}$ & $\begin{array}{l}\text { Determines effects of temperature on } \\
\text { organic matter decay }\end{array}$ & $30^{\circ} \mathrm{C}$ & $25^{\circ} \mathrm{C}$ \\
\hline $\begin{array}{l}\text { Fraction of maximum organic matter } \\
\text { decay at lower temperature }\end{array}$ & $\begin{array}{l}\text { Determines effects of temperature on } \\
\text { organic matter decay }\end{array}$ & 0.95 & 0.95 \\
\hline Sediment decay rate & $\begin{array}{l}\text { Decay rate of organic matter in bed } \\
\text { sediments }\end{array}$ & $0.002 / \mathrm{d}$ & $0.005 / \mathrm{d}-0.015 / \mathrm{d}$ \\
\hline Sediment oxygen demand & $\begin{array}{l}\text { Zero-order sediment oxygen demand for } \\
\text { each computational segment }\end{array}$ & $0.0-0.30\left(\mathrm{~g} / \mathrm{m}^{2}\right) / \mathrm{d}$ & $0.0-1.9\left(\mathrm{~g} / \mathrm{m}^{2}\right) / \mathrm{d}$ \\
\hline $\begin{array}{l}\text { 5-day biological oxygen demand decay } \\
\text { rate }\end{array}$ & $\begin{array}{l}\text { Calculate effects of BOD loading on } \\
\text { dissolved oxygen }\end{array}$ & $0.25 / \mathrm{d}$ & $0.15 / \mathrm{d}-0.25 / \mathrm{d}$ \\
\hline BOD temperature rate coefficient & $\begin{array}{l}\text { Adjusts 5-day BOD decay rate at } 20^{\circ} \mathrm{C} \\
\text { to ambient temperature }\end{array}$ & $\begin{array}{c}1.047 \\
\text { (dimensionless) }\end{array}$ & $\begin{array}{c}1.047 \\
\text { (dimensionless) }\end{array}$ \\
\hline Ratio of 5-day BOD to ultimate BOD & $\begin{array}{l}\text { Calculate effects of BOD loading on } \\
\text { dissolved oxygen }\end{array}$ & $\begin{array}{c}1.85 \\
\text { (dimensionless) }\end{array}$ & $\begin{array}{c}1.85 \\
\text { (dimensionless) }\end{array}$ \\
\hline $\begin{array}{l}\text { Release rate of phosphorus from bottom } \\
\text { sediments }\end{array}$ & $\begin{array}{l}\text { Calculate phosphorus balance; } \\
\text { computed as a fraction of the sediment } \\
\text { oxygen demand }\end{array}$ & $\begin{array}{c}0.0001 \\
\text { (dimensionless) }\end{array}$ & $\begin{array}{c}0.005-0.0001 \\
(\text { dimensionless })\end{array}$ \\
\hline Phosphorus partitioning coefficient & $\begin{array}{l}\text { Describes sorption of phosphorus on to } \\
\text { suspended solids }\end{array}$ & $\begin{array}{c}1.0 \\
\text { (dimensionless) }\end{array}$ & $\begin{array}{c}2.0-3.0 \\
(\text { dimensionless) }\end{array}$ \\
\hline
\end{tabular}


Table 16. Rate coefficients used in water-chemistry simulations for Mountain Island Lake-Continued

$\left[\mathrm{m} / \mathrm{d}\right.$; meter per day; watts $/ \mathrm{m}^{2}$, watts per square meter; ${ }^{\circ} \mathrm{C}$, degree Celsius; $\left(\mathrm{g} / \mathrm{m}^{2}\right) / \mathrm{d}$, gram per square meter per day; BOD, biochemical oxygen demand; $\mathrm{g} / \mathrm{m}^{3}$, gram per cubic meter; $\mathrm{mg} / \mathrm{L}$, milligram per liter]

\begin{tabular}{|c|c|c|c|}
\hline Parameter & Purpose & $\begin{array}{c}\text { Calibrated value in } \\
\text { Mountain Island } \\
\text { Lake model }\end{array}$ & $\begin{array}{l}\text { Calibrated values in } \\
\text { Rhodhiss Lake and } \\
\text { Lake Hickory models }\end{array}$ \\
\hline $\begin{array}{l}\text { Algal half-saturation constant for } \\
\text { phosphorus }\end{array}$ & $\begin{array}{l}\text { The phosphorus concentration at which } \\
\text { the uptake rate is one-half the maxi- } \\
\text { mum uptake rate; upper concentration } \\
\text { at which algal growth is proportional } \\
\text { to phosphorus concentration }\end{array}$ & $0.001 \mathrm{~g} / \mathrm{m}^{3}$ & $0.005 \mathrm{~g} / \mathrm{m}^{3}$ \\
\hline $\begin{array}{l}\text { Release rate of ammonia from bottom } \\
\text { sediments }\end{array}$ & $\begin{array}{l}\text { Calculate nitrogen balance; computed as } \\
\text { a fraction of the sediment oxygen } \\
\text { demand }\end{array}$ & $\begin{array}{c}0.010 \\
\text { (dimensionless) }\end{array}$ & $\begin{array}{c}0.003-0.040 \\
\text { (dimensionless) }\end{array}$ \\
\hline Ammonia decay rate & $\begin{array}{l}\text { Rate at which ammonia is oxidized to } \\
\text { nitrate }\end{array}$ & $0.2 / \mathrm{d}$ & $0.2 / \mathrm{d}$ \\
\hline $\begin{array}{l}\text { Algal half-saturation constant for } \\
\text { ammonia }\end{array}$ & $\begin{array}{l}\text { Nitrogen concentration at which the algal } \\
\text { uptake rate is one-half the maximum } \\
\text { uptake rate }\end{array}$ & $0.02 \mathrm{~g} / \mathrm{m}^{3}$ & $0.014 \mathrm{~g} / \mathrm{m}^{3}$ \\
\hline Lower temperature for ammonia decay & $\begin{array}{l}\text { Describes effects of temperature on } \\
\text { ammonia nitrification }\end{array}$ & $10{ }^{\circ} \mathrm{C}$ & $5^{\circ} \mathrm{C}-10{ }^{\circ} \mathrm{C}$ \\
\hline $\begin{array}{l}\text { Fraction of nitrification at lower } \\
\text { temperature }\end{array}$ & $\begin{array}{l}\text { Describes effects of temperature on } \\
\text { ammonia nitrification }\end{array}$ & $\begin{array}{c}0.10 \\
\text { (dimensionless) }\end{array}$ & $\begin{array}{c}0.10 \\
\text { (dimensionless) }\end{array}$ \\
\hline $\begin{array}{l}\text { Lower temperature for maximum } \\
\text { ammonia decay }\end{array}$ & $\begin{array}{l}\text { Describes effects of temperature on } \\
\text { ammonia nitrification }\end{array}$ & $25^{\circ} \mathrm{C}$ & $25^{\circ} \mathrm{C}$ \\
\hline $\begin{array}{l}\text { Fraction of maximum nitrification at } \\
\text { lower temperature }\end{array}$ & $\begin{array}{l}\text { Describes effects of temperature on } \\
\text { ammonia nitrification }\end{array}$ & $\begin{array}{c}0.99 \\
\text { (dimensionless) }\end{array}$ & $\begin{array}{c}0.99 \\
\text { (dimensionless) }\end{array}$ \\
\hline Nitrate decay rate & $\begin{array}{l}\text { Rate at which nitrate is denitrified; } \\
\text { temperature dependent }\end{array}$ & $0.1 / \mathrm{d}$ & $0.15 / \mathrm{d}-2.0 / \mathrm{d}$ \\
\hline Lower temperature for nitrate decay & $\begin{array}{l}\text { Describes the effects of temperature on } \\
\text { denitrification }\end{array}$ & $5.0^{\circ} \mathrm{C}$ & $5.0^{\circ} \mathrm{C}$ \\
\hline $\begin{array}{l}\text { Fraction of denitrification at lower } \\
\text { temperature }\end{array}$ & $\begin{array}{l}\text { Describes the effects of temperature on } \\
\text { denitrification }\end{array}$ & $\begin{array}{c}0.01 \\
\text { (dimensionless) }\end{array}$ & $\begin{array}{c}0.1-0.2 \\
\text { (dimensionless) }\end{array}$ \\
\hline $\begin{array}{l}\text { Lower temperature for maximum nitrate } \\
\text { decay }\end{array}$ & $\begin{array}{l}\text { Describes the effects of temperature on } \\
\text { denitrification }\end{array}$ & $30{ }^{\circ} \mathrm{C}$ & $25^{\circ} \mathrm{C}-30{ }^{\circ} \mathrm{C}$ \\
\hline $\begin{array}{l}\text { Fraction of maximum denitrification at } \\
\text { lower temperature }\end{array}$ & $\begin{array}{l}\text { Describes the effects of temperature on } \\
\text { denitrification }\end{array}$ & $\begin{array}{c}0.99 \\
\text { (dimensionless) }\end{array}$ & $\begin{array}{c}0.99 \\
\text { (dimensionless) }\end{array}$ \\
\hline Iron release rate from bottom sediments & $\begin{array}{l}\text { Calculate iron balance; computed as } \\
\text { fraction of sediment oxygen demand }\end{array}$ & $\begin{array}{c}1.0 \\
\text { (dimensionless) }\end{array}$ & $\begin{array}{c}1.0 \\
\text { (dimensionless) }\end{array}$ \\
\hline Iron settling velocity & $\begin{array}{l}\text { Particulate iron settling velocity under } \\
\text { oxic conditions }\end{array}$ & $2.0 \mathrm{~m} / \mathrm{d}$ & $2.0 \mathrm{~m} / \mathrm{d}$ \\
\hline $\begin{array}{l}\text { Oxygen stoichiometric equivalent for } \\
\text { ammonia decay }\end{array}$ & $\begin{array}{l}\text { Relates oxygen consumption to ammonia } \\
\text { decay }\end{array}$ & $\begin{array}{c}4.57 \\
\text { (dimensionless) }\end{array}$ & $\begin{array}{c}4.0-4.57 \\
\text { (dimensionless) }\end{array}$ \\
\hline $\begin{array}{l}\text { Oxygen stoichiometric equivalent for } \\
\text { organic matter decay }\end{array}$ & $\begin{array}{l}\text { Relates oxygen consumption to decay of } \\
\text { organic matter }\end{array}$ & $\begin{array}{c}1.4 \\
\text { (dimensionless) }\end{array}$ & $\begin{array}{c}1.4-1.5 \\
\text { (dimensionless) }\end{array}$ \\
\hline $\begin{array}{l}\text { Oxygen stoichiometric equivalent for } \\
\text { dark respiration }\end{array}$ & $\begin{array}{l}\text { Relates oxygen consumption to algae } \\
\text { dark respiration }\end{array}$ & $\begin{array}{c}1.4 \\
\text { (dimensionless) }\end{array}$ & $\begin{array}{c}0.9-1.4 \\
\text { (dimensionless) }\end{array}$ \\
\hline $\begin{array}{l}\text { Oxygen stoichiometric equivalent for } \\
\text { algal growth }\end{array}$ & $\begin{array}{l}\text { Relates oxygen production to algae } \\
\text { growth }\end{array}$ & $\begin{array}{c}3.0 \\
\text { (dimensionless) }\end{array}$ & $\begin{array}{c}3.0 \\
\text { (dimensionless) }\end{array}$ \\
\hline $\begin{array}{l}\text { Stoichiometric equivalent between } \\
\text { organic matter and phosphorus }\end{array}$ & $\begin{array}{l}\text { Relates phosphorus release to decay of } \\
\text { organic matter }\end{array}$ & $\begin{array}{c}0.011 \\
\text { (dimensionless) }\end{array}$ & $\begin{array}{c}0.009-0.011 \\
\text { (dimensionless) }\end{array}$ \\
\hline $\begin{array}{l}\text { Stoichiometric equivalent between } \\
\text { organic matter and nitrogen }\end{array}$ & $\begin{array}{l}\text { Relates nitrogen release to decay of } \\
\text { organic matter }\end{array}$ & $\begin{array}{c}0.08 \\
\text { (dimensionless) }\end{array}$ & $\begin{array}{c}0.08 \\
\text { (dimensionless) }\end{array}$ \\
\hline Dissolved-oxygen limit & $\begin{array}{l}\text { Dissolved-oxygen concentration below } \\
\text { anaerobic processes, such as } \\
\text { nitrification and sediment nutrient } \\
\text { releases occur }\end{array}$ & $0.1 \mathrm{mg} / \mathrm{L}$ & $0.1 \mathrm{mg} / \mathrm{L}$ \\
\hline
\end{tabular}




\section{Nitrate}

Agreement between measured and simulated $\mathrm{NO}_{3}$ concentrations was fair for Gar Creek cove and the mainstem of the reservoir (fig. 28). Seasonal variations in $\mathrm{NO}_{3}$ concentrations were accurately simulated at the cove site and two mainstem sites (fig. 28B-D), and simulated $\mathrm{NO}_{3}$ concentrations generally were within 0.05 to $0.10 \mathrm{mg} / \mathrm{L}$ of measured values, particularly in the mainstem of the reservoir (fig. 28B, D). Nitrate concentrations were simulated accurately for the late fall through early to late spring. During the rest of the year, predicted $\mathrm{NO}_{3}$ concentrations exceeded measured values. The most likely reason for this overprediction of $\mathrm{NO}_{3}$ is that the denitrification process, which increases with increasing water temperature, is not included in CE-QUAL-W2 water-chemistry algorithms. Hence, denitrification reduces $\mathrm{NO}_{3}$ concentrations in the reservoir during warm months, but the model does not account for this process. Denitrification seems to be particularly important in the Gar Creek cove and appears to begin earlier in the year in this cove than in the mainstem, probably because the onset of warmer temperatures occurs sooner in the cove than in the mainstem.

Nitrate concentrations were not simulated accurately in the McDowell Creek cove for several periods. The underprediction of $\mathrm{NO}_{3}$ in this cove appears to be the result of an underestimate of $\mathrm{NO}_{3}$ loads from McDowell Creek during runoff events (fig. 24B). Four of the five largest daily mean streamflows in McDowell Creek during the study occurred between late February and late July 1997, when $\mathrm{NO}_{3}$ in $\mathrm{McD}$ owell Creek cove was underpredicted. Subsequent testing also indicated that predicted $\mathrm{NO}_{3}$ concentrations in McDowell Creek cove were sensitive to estimated McDowell Creek inflow $\mathrm{NO}_{3}$ concentrations. Improvements between measured and simulated $\mathrm{NO}_{3}$ concentrations in McDowell Creek cove could have been obtained by adjusting inflow $\mathrm{NO}_{3}$ concentrations in McDowell Creek until simulated concentrations in the cove agreed more closely with measured values. The simulations were made, however, using the best estimates of loadings rather than using loadings as a calibration parameter. Moreover, because algal productivity in Mountain Island Lake is limited by phosphorus concentrations, light, and residence time, accurate simulations of algal concentrations and related DO concentrations are not dependent on accurate simulations of $\mathrm{NO}_{3}$.

The effects of high flows in McDowell Creek on $\mathrm{NO}_{3}$ concentrations in Mountain Island Lake can be seen from the simulations for June 20-21, 1996 (fig. 29). A late-night storm on June 19 resulted in a peak flow of about $63 \mathrm{~m}^{3} / \mathrm{s}$ in McDowell Creek at 1:00 a.m. on June 20. Flows in McDowell Creek typically are less than $0.5 \mathrm{~m}^{3} / \mathrm{s}$. At midnight on June 20, $\mathrm{NO}_{3}$ concentrations in Mountain Island Lake generally were less than $0.3 \mathrm{mg} / \mathrm{L}$ (fig. 29A). By noon on June 20, the high flows entering McDowell Creek cove had entered Mountain Island Lake at about 10,000 m from Mountain Island Dam (fig. 29B). Because the water temperature of the stormflow was colder than the water in the reservoir, the stormflow entered the lake near the bottom of the channel. As a result of the increased $\mathrm{NO}_{3}$ load and higher inflows, $\mathrm{NO}_{3}$ concentrations in the lake near the mouth of McDowell Creek cove were as high as $0.8 \mathrm{mg} / \mathrm{L}$. The effects of this particular event on $\mathrm{NO}_{3}$ concentrations in the lake, however, were fairly short-lived (fig. 29C).

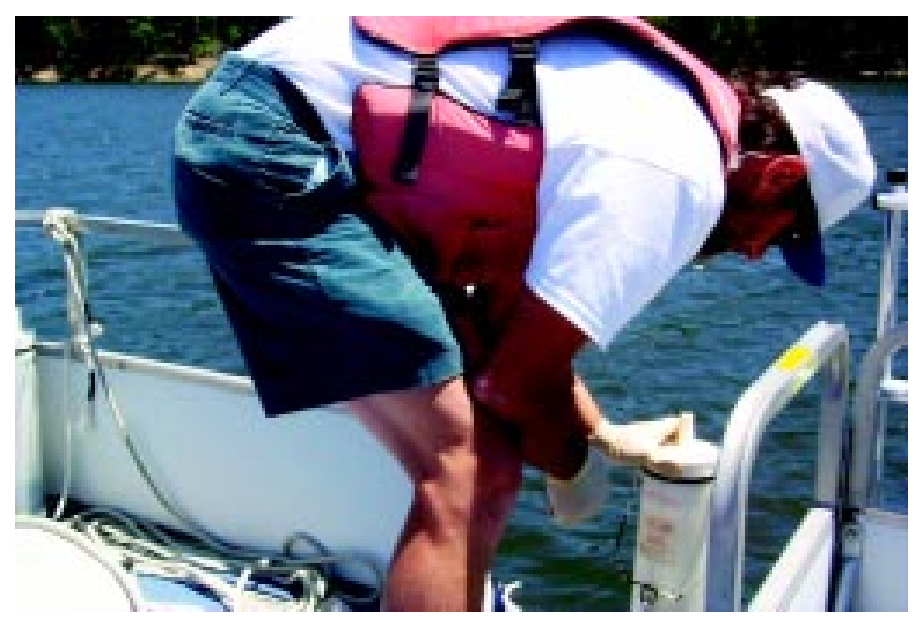

USGS personnel collecting lake water-quality samples (photograph by R.G. Garrett, USGS) 

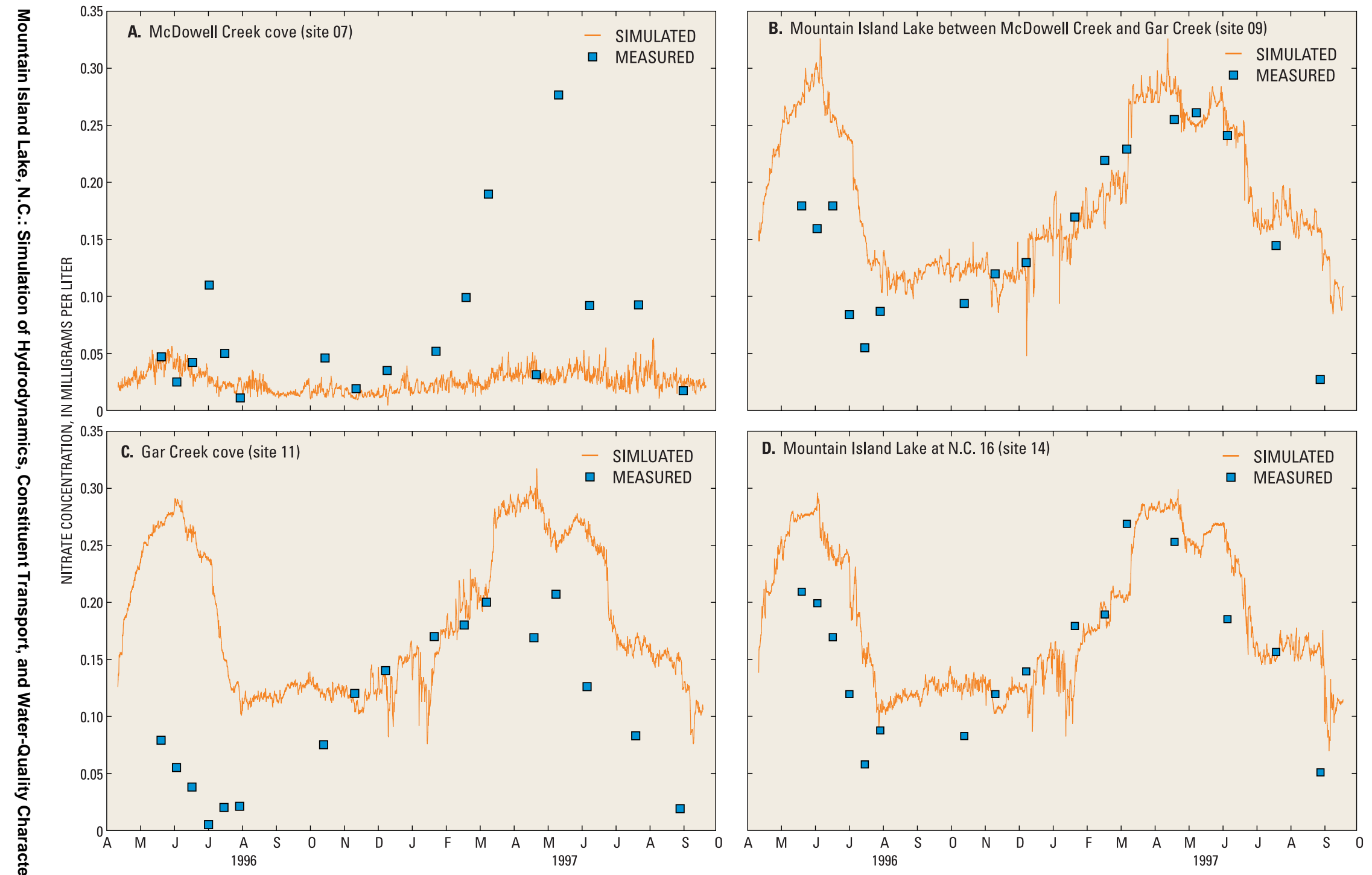

Figure 28. Measured and simulated near-surface nitrate concentrations at (A) McDowell Creek cove (site 07), (B) Mountain Island Lake between McDowell Creek and Gar Creek (site 09), (C) Gar Creek cove (site 11), and (D) Mountain Island Lake at N.C. Highway 16 (site 14) for April $1996-O c t o b e r ~ 1997$. 

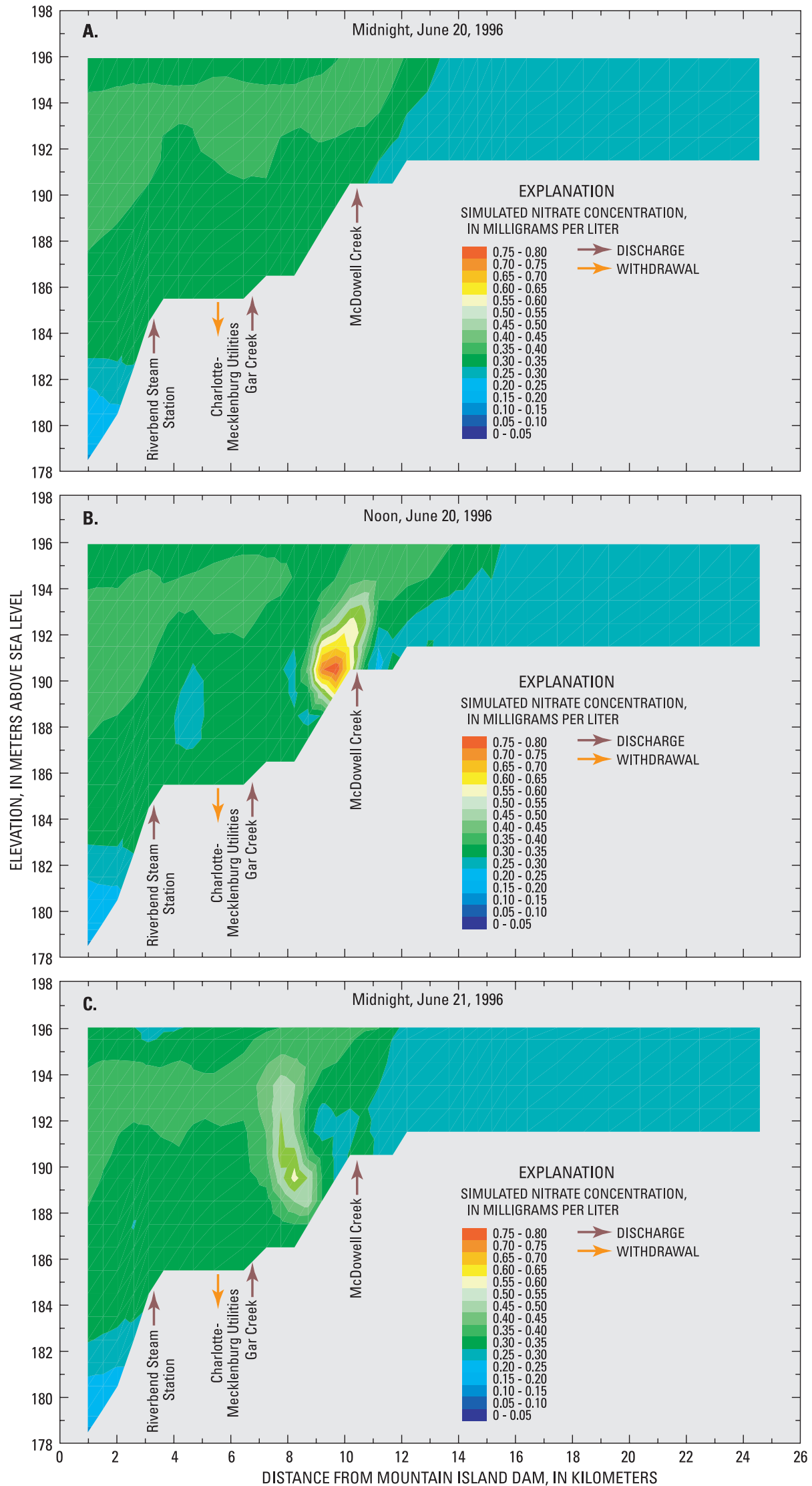

Figure 29. Simulated nitrate concentrations in Mountain Island Lake for (A) midnight on June 20, 1996, (B) noon on June 20 , 1996, and (C) midnight on June 21, 1996, demonstrating the effects of stormflow in McDowell Creek on nitrate concentrations in Mountain Island Lake. [Note: Contour resolution is greater than that shown in explanation color bar]. 


\section{Ammonia}

Ammonia concentrations were accurately simulated throughout the reservoir, both in the mainstem and the coves (fig. 30). Simulated $\mathrm{NH}_{4}$ concentrations seldom differed from measured values by more than $0.01 \mathrm{mg} / \mathrm{L}$, and the seasonal increase in $\mathrm{NH}_{4}$ during the spring of 1997 was accurately simulated. The biggest difference between measured and simulated $\mathrm{NH}_{4}$ concentrations was in the coves for the period April-July 1997, when $\mathrm{NH}_{4}$ loads from Gar and $\mathrm{McD}$ owell Creek were likely underestimated for several large storm events, as was the case for $\mathrm{NO}_{3}$. Nevertheless, $\mathrm{NH}_{4}$ concentrations were accurately simulated in the reservoir for this period.

\section{Orthophosphorus}

Both measured and simulated near-surface $\mathrm{PO}_{4}$ concentrations typically were less than $0.005 \mathrm{mg} / \mathrm{L}$ at all locations other than in McDowell Creek cove (fig. 31). As with $\mathrm{NO}_{3}$, it appears that $\mathrm{PO}_{4}$ loads from McDowell Creek were underestimated, resulting in an underprediction of $\mathrm{PO}_{4}$ concentrations in the cove for some periods (fig. 31A). Also, Gar Creek loads may have been overestimated for storms at the beginning of March and the end of July 1997 (fig. 31C). Simulated $\mathrm{PO}_{4}$ concentrations were elevated at all locations at the beginning of the study period (April 1996). Sensitivity testing indicated that these overpredictions were not the result of incorrect initial conditions, so $\mathrm{PO}_{4}$ loads probably were overestimated at one or more locations at the beginning of the simulation period.

\section{Chlorophyll a}

Accurate simulations of algal biomass (as indicated by chlorophyll $a$ concentrations) are difficult for several reasons. First, algae are not uniformly distributed in the water column but commonly occur irregularly as patches. Consequently, a single point sample may not be representative of actual mean concentration in a reservoir segment. Second, algae in this model are simulated as a single assemblage having a single temperature growth rate function, a single mortality rate, and so on. Hence, distinctions among different algal types that bloom under different ambient conditions cannot be made by these model simulations. Version 3.0 of CE-QUAL-W2 allows multiple assemblages to be simulated (T. Cole, U.S. Army Corps of Engineers, oral commun., July 2000). Third, simulated algal concentrations represent the accumulated results of simulated solids concentrations, light penetration, water temperature, nutrient concentrations, and mixing. Errors in the simulation of these constituents and errors in estimates of loading are reflected in simulated algal concentrations. Finally, algal biomass is simulated, but chlorophyll $a$ was measured in this study. As previously indicated, the relation between biomass and chlorophyll $a$ concentrations was based on a single factor, and no data were collected to verify this factor for Mountain Island Lake.

The overall seasonal patterns of chlorophyll $a$ concentrations in Mountain Island Lake were reproduced by the water-quality simulations (fig. 32). The simulated elevated $\mathrm{PO}_{4}$ concentrations during the spring of 1996 (fig. 31) resulted in simulation of a spring bloom in the reservoir (fig. 32). Maximum observed concentrations during this time were underpredicted in McDowell Creek cove and generally were accurate elsewhere (fig. 32). The underprediction of $\mathrm{PO}_{4}$ in McDowell Creek cove in the summer of 1996 (fig. 31) resulted in the underprediction of chlorophyll $a$ in the cove. Maximum simulated concentrations occurred about a month before maximum concentrations were observed at all sites in the reservoir. A single observed occurrence of elevated chlorophyll $a$ concentration in McDowell Creek cove in October 1996 was not simulated, but elevated concentrations were not observed elsewhere in the reservoir. The general pattern of a seasonal increase in chlorophyll $a$ concentrations throughout the reservoir in the summer of 1997 was reproduced by the simulations (fig. 32). Overall, algal dynamics in Mountain Island Lake were simulated adequately, in that simulated algal biomass varies spatially in a manner similar to observations and varies temporally in response to changing loads, light availability (based on solids concentrations), and water temperature. 

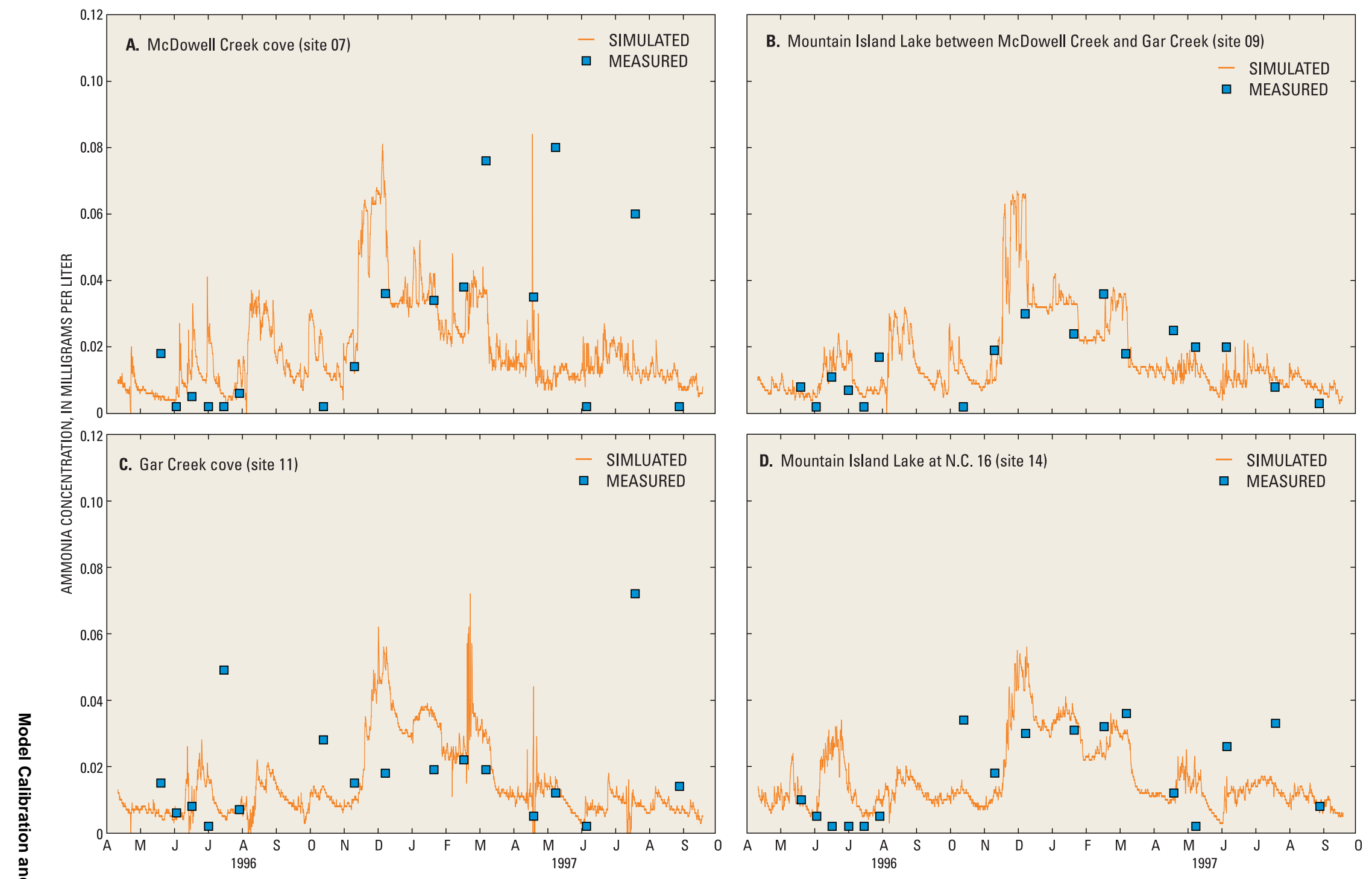

Figure 30. Measured and simulated near-surface ammonia concentrations at (A) McDowell Creek cove (site 07), (B) Mountain Island Lake between McDowell Creek and Gar Creek (site 09); (C) Gar Creek cove (site 11), and (D) Mountain Island Lake at N.C. Highway 16 (site 14) for April $1996-O c t o b e r ~ 1997$. 

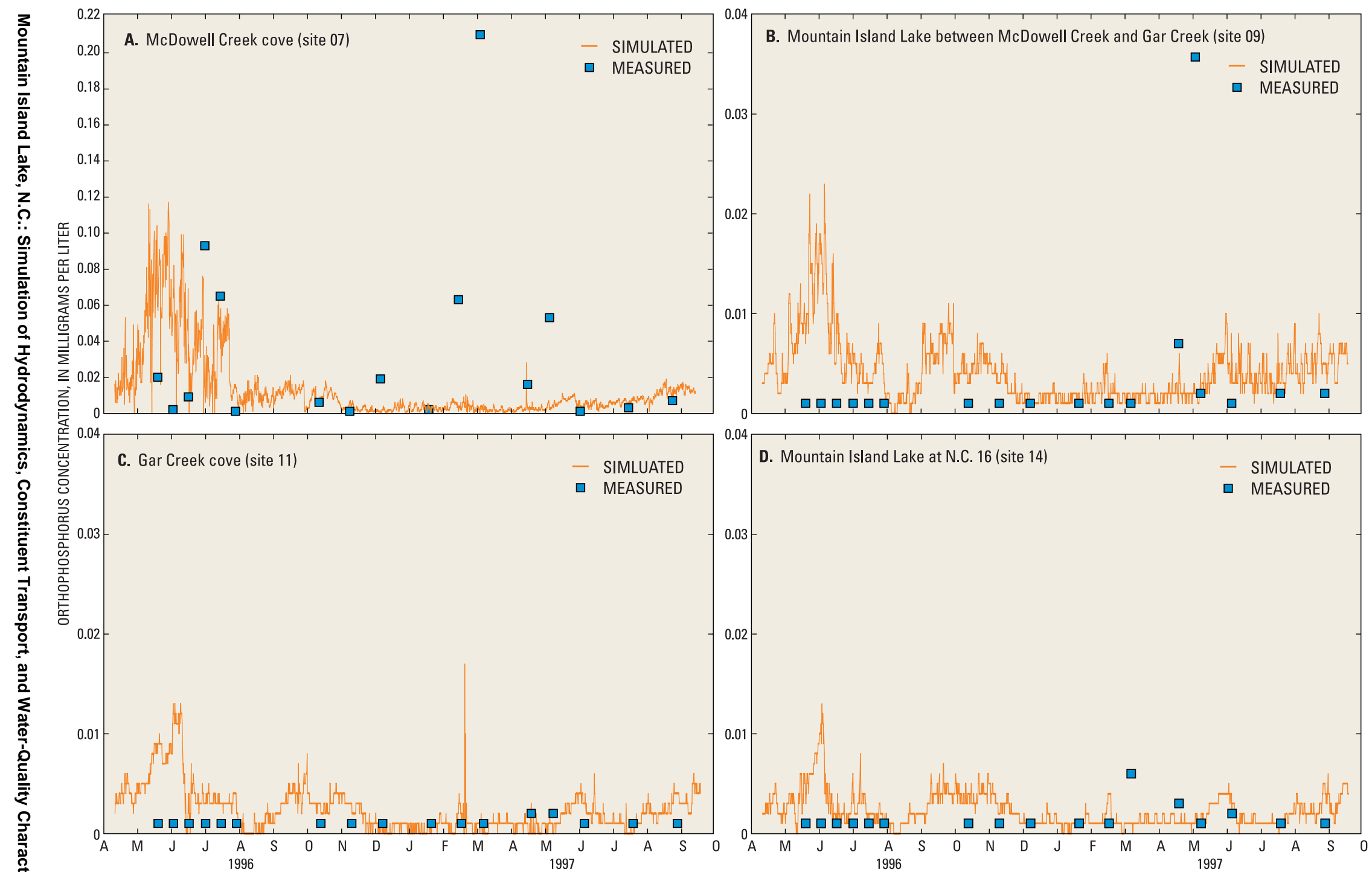

Figure 31. Measured and simulated near-surface orthophosphorus concentrations at (A) McDowell Creek cove (site 07), (B) Mountain Island Lake between McDowell Creek and Gar Creek (site 09), (C) Gar Creek cove (site 11), and (D) Mountain Island Lake at N.C. Highway 16 (site 14) for April $1996-O c t o b e r ~ 1997$. 

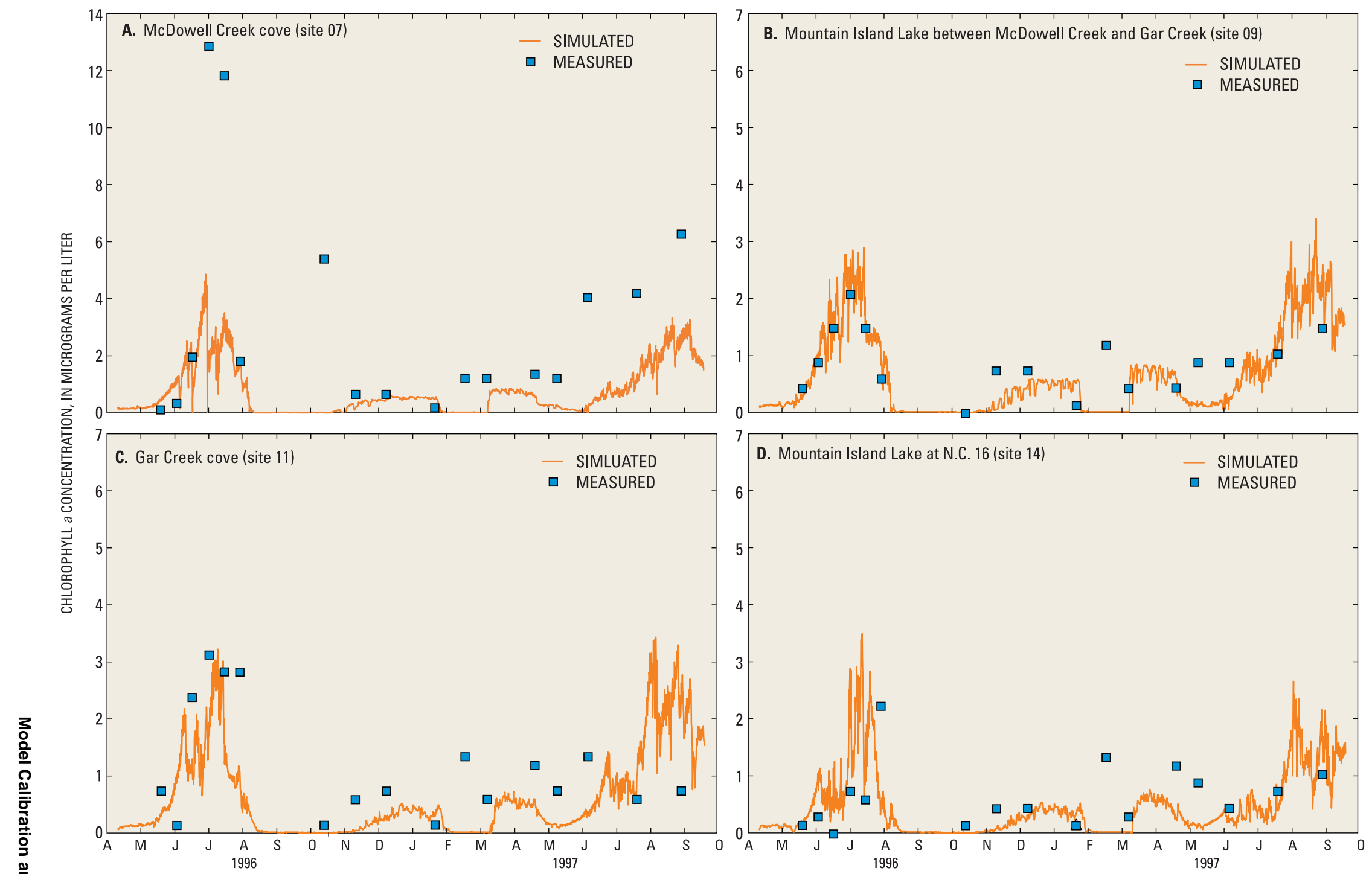

Figure 32. Measured and simulated near-surface chlorophyll a concentrations at (A) McDowell Creek cove (site 07), (B) Mountain Island Lake between McDowell Creek and Gar Creek (site 09), (C) Gar Creek cove (site 11), and (D) Mountain Island Lake at N.C. Highway 16 (site 14) for April $1996-O c t o b e r ~ 1997$. 


\section{Dissolved Oxygen}

Measured and simulated DO concentrations agreed very closely for site 14 , where continuous measurements of near-surface and near-bottom DO were made during the study (fig. 33). For near-surface measurements, the mean difference between the measured and simulated DO concentrations was $0.2 \mathrm{mg} / \mathrm{L}$ for the simulation period, and the root-meansquare difference was $0.7 \mathrm{mg} / \mathrm{L}$. For near-bottom measurements, the mean difference also was $0.2 \mathrm{mg} / \mathrm{L}$, and the root-mean-square difference was $1.1 \mathrm{mg} / \mathrm{L}$. These results indicate that there was a slight tendency to overestimate $\mathrm{DO}$ concentrations, but that DO

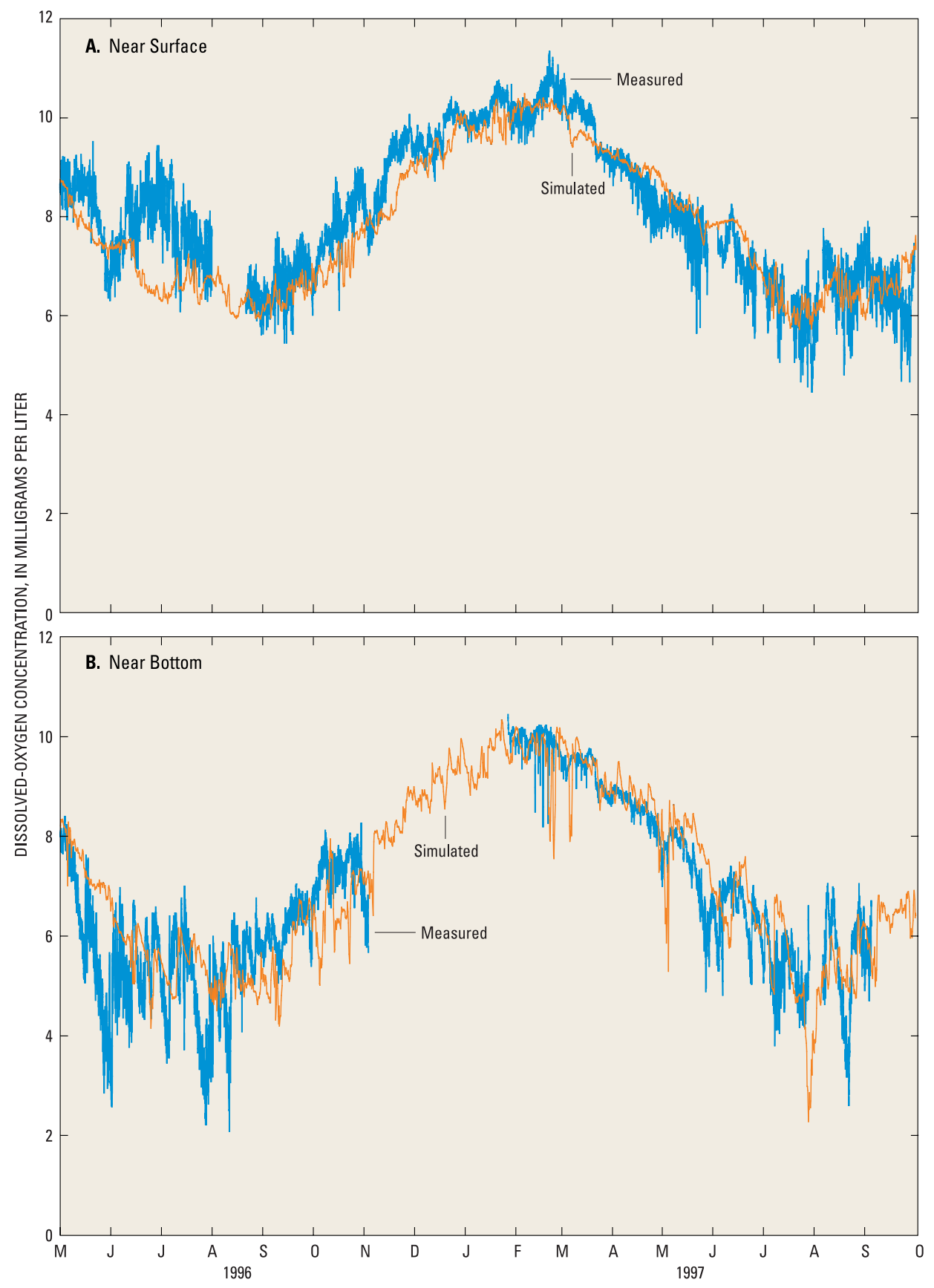

Figure 33. Measured and simulated $(A)$ near-surface and $(B)$ near-bottom dissolvedoxygen concentrations in Mountain Island Lake at N.C. Highway 16 (site 14) for May 1996-October 1997. 
concentrations were simulated with very nearly the same accuracy as DO is measured in the field.

Very little parameter adjustment was required to achieve these results. Recommended (or default) parameter values (Cole and Buchak, 1995) were used in the simulations. Sediment oxygen demand rates were very low (table 16) - typically less than 0.1 gram per square meter per day $\left(\left[\mathrm{g} / \mathrm{m}^{2}\right] / \mathrm{d}\right)$ - particularly compared to rates used in the Rhodhiss Lake and Lake Hickory water-quality models. As in the Rhodhiss Lake and Lake Hickory models, some adjustment to the model reaeration rate algorithm in the model computer code was required to increase reaeration and achieve satisfactory near-surface simulations.

Simulated vertical profiles of DO concentration were compared with all available measured profiles for mainstem sites 08 (segment 20, at the mouth of McDowell Creek), 09 (segment 25), and 14 (segment 33; fig. 34), and for cove sites 07 (segment 41, McDowell Creek cove), 11 (segment 52, Gar Creek cove), and 13 (segment 58). A total of 23 measured and simulated vertical profiles of DO were compared at each of these sites. The error statistics for the simulated vertical profiles of DO were about the same as those for the simulated time series (table 17), with median differences between measured and simulated values ranging from 0 to $-0.3 \mathrm{mg} / \mathrm{L}$, and root-mean-square differences ranging from 0.7 to $1.2 \mathrm{mg} / \mathrm{L}$ (table 17). Vertical distributions of DO were simulated equally well in the mainstem of the reservoir and in the coves (table 17), with the exception of McDowell Creek cove (site 07), where the percentages of simulated values within \pm 0.5 and $\pm 1.0 \mathrm{mg} / \mathrm{L}$ of measured values were somewhat lower than at other sites. There was a bias toward underprediction of DO concentrations in the vertical profiles at the cove sites and the upstreammost mainstem site.

\section{Sensitivity Analysis}

Sensitivity analysis is the determination of the effects of changes in model parameters and boundary conditions on simulated results. A formal sensitivity analysis, including all of the model parameters (tables 14 and 16) in the Mountain Island Lake waterquality model, was not performed. However, more than 50 simulations were made during the calibration process, and more than 75 simulations were made previously with the Rhodhiss Lake (Giorgino and Bales, 1997) and Lake Hickory (Bales and Giorgino, 1998) water-quality models_-both of which are based on the same modeling code as the Mountain Island Lake water-quality model. Models of all three reservoirs behaved similarly, and results from these simulations form the basis for the sensitivity analysis presented here.

Water-level simulations were quite sensitive to inflow changes. The storage volume of the reservoir between elevations 196 and $197 \mathrm{~m}$ above mean sea level-typical water-level elevations for Mountain Island Lake (site 14, fig. 25) -is about 11 million $\mathrm{m}^{3}$. Consequently, an error in the estimate of daily mean inflow (or outflow) of $1 \mathrm{~m}^{3} / \mathrm{s}$ over a period of about 4 months would result in an error in simulated water level of about $1 \mathrm{~m}$. Simulations were not sensitive, however, to changes in hydraulic and thermal parameters (table 14). Small-scale physical processes are resolved well by the relatively detailed Mountain Island Lake computational grid, and subgrid-scale processes represented by these parameters were relatively unimportant, resulting in an insensitivity of simulations to reasonable changes in these parameters.

Two model parameters that indirectly affect simulations of vertical distributions of temperature and water-quality constituents are the wind sheltering coefficient and resistance coefficient. Simulations of water temperature and DO concentrations for Mountain Island Lake were not particularly sensitive to changes in either parameter. Simulations also were insensitive to changes in parameter-controlling heat exchange at the bottom of the reservoir.

Nearly 60 parameters that affect chemical kinetics were specified as input to the Mountain Island Lake model (table 16). Values of most parameters did not differ appreciably from those used in the Rhodhiss Lake and Lake Hickory models (table 16), and generally were within the range of values suggested by Cole and Buchak (1995).

Simulated algal concentrations were most sensitive to the algal growth rate, somewhat sensitive to changes in the saturation light intensity and the algal half-saturation constant for phosphorus, and insensitive to changes in the mortality rate, settling rate, and the nitrogen half-saturation constant. Simulated algal concentrations also were insensitive to changes in the temperature rate multipliers, but the timing and ending of algal growth was affected by these multipliers. Algal concentrations were controlled by the amount of $\mathrm{PO}_{4}$ in the upper layers of the reservoir and by the availability of light, which was in turn affected by the concentration of suspended organic 


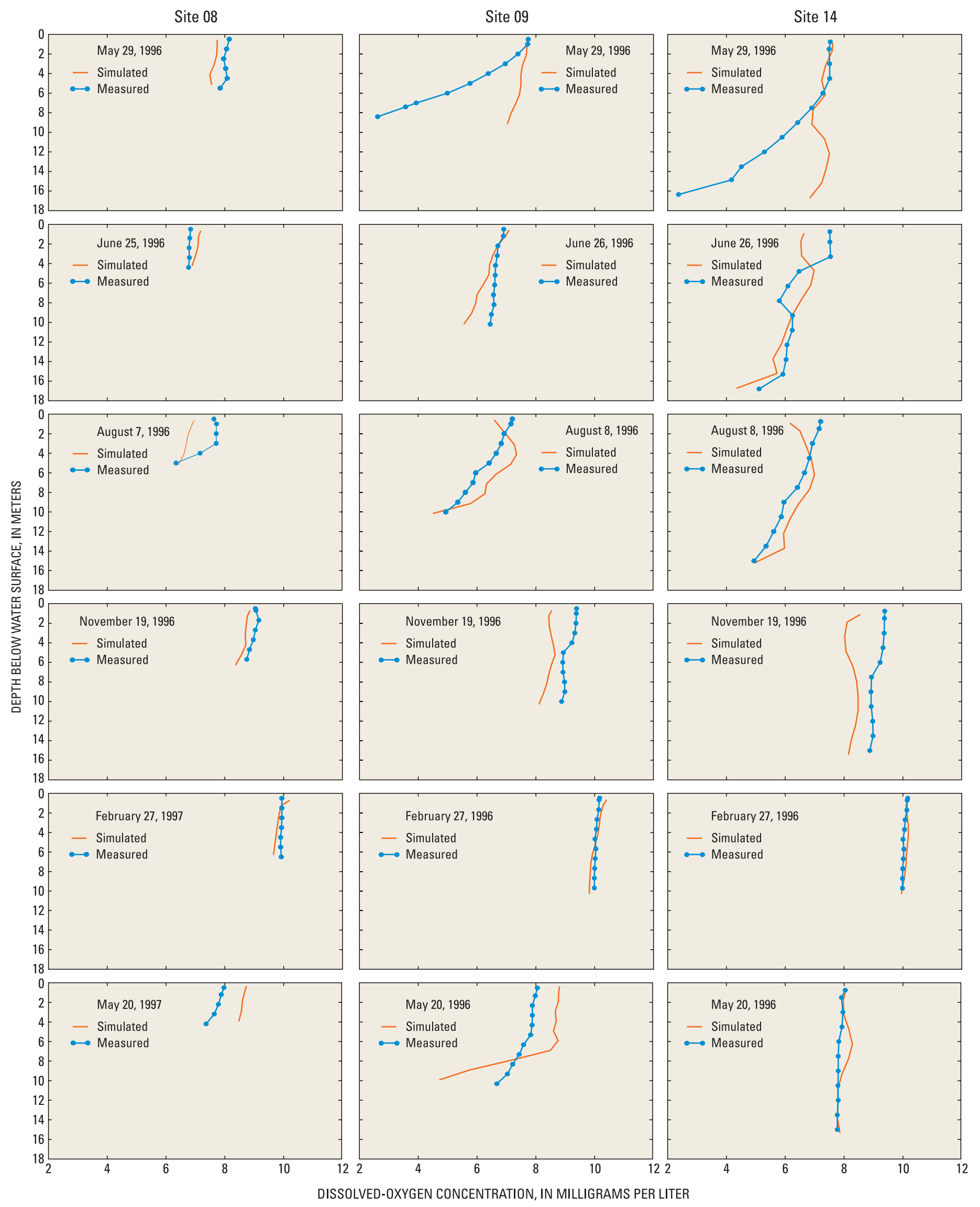

Figure 34. Measured and simulated vertical distributions of dissolved-oxygen concentration at three mainstem locations in Mountain Island Lake for six sets of measurements between May 1996 and May 1997. 
Table 17. Comparison of measured and simulated dissolved-oxygen concentrations for Mountain Island Lake sites [mg/L, milligram per liter; RMS, root mean square difference; \pm , plus or minus]

\begin{tabular}{|c|c|c|c|c|c|c|c|}
\hline \multirow{3}{*}{$\begin{array}{l}\text { Site } \\
\text { (fig. 2) }\end{array}$} & \multirow{3}{*}{$\begin{array}{c}\text { Measurement } \\
\text { type } \\
\text { (location) }\end{array}$} & \multirow{3}{*}{$\begin{array}{c}\text { Number } \\
\text { of } \\
\text { observations }\end{array}$} & \multicolumn{5}{|c|}{$\begin{array}{l}\text { Difference between measured and simulated } \\
\text { dissolved-oxygen concentrations }\end{array}$} \\
\hline & & & \multirow{2}{*}{$\begin{array}{l}\text { Mean } \\
(\mathrm{mg} / \mathrm{L})\end{array}$} & \multirow{2}{*}{$\begin{array}{c}\text { Median } \\
\text { (mg/L) }\end{array}$} & \multirow{2}{*}{$\begin{array}{c}\text { RMS } \\
(\mathrm{mg} / \mathrm{L})\end{array}$} & \multicolumn{2}{|c|}{ Percent of difference } \\
\hline & & & & & & $\begin{array}{l}\text { within } \\
\pm 0.5 \mathrm{mg} / \mathrm{L}\end{array}$ & $\begin{aligned} & \text { within } \\
& \pm 1.0 \mathrm{mg} / \mathrm{L} \\
&\end{aligned}$ \\
\hline 14 & $\begin{array}{l}\text { Time series } \\
\text { (near surface) }\end{array}$ & 2,112 & 0.2 & 0.2 & 0.7 & 61 & 88 \\
\hline 14 & $\begin{array}{l}\text { Time series } \\
\text { (near bottom) }\end{array}$ & 2,009 & .2 & .2 & 1.1 & 41 & 67 \\
\hline 08 & $\begin{array}{l}\text { Profile } \\
\text { (mainstem) }\end{array}$ & 137 & -.1 & -.2 & .7 & 49 & 89 \\
\hline 09 & $\begin{array}{l}\text { Profile } \\
\text { (mainstem) }\end{array}$ & 252 & .2 & 0 & 1.1 & 48 & 82 \\
\hline 14 & $\begin{array}{l}\text { Profile } \\
\text { (mainstem) }\end{array}$ & 258 & 0 & 0 & .9 & 45 & 76 \\
\hline 07 & $\begin{array}{l}\text { Profile } \\
\text { (cove) }\end{array}$ & 94 & -.1 & -.2 & 1.2 & 35 & 54 \\
\hline 11 & $\begin{array}{l}\text { Profile } \\
\text { (cove) }\end{array}$ & 95 & -.5 & -.3 & 1.0 & 54 & 85 \\
\hline 13 & $\begin{array}{l}\text { Profile } \\
\text { (cove) }\end{array}$ & 161 & -.6 & -.3 & 1.1 & 59 & 80 \\
\hline
\end{tabular}

and inorganic solids. Hence, accurate estimates of loadings to the reservoir are required for accurate simulations of algal biomass. In addition, a sitespecific measure of the factor used to convert between simulated algal biomass and measured chlorophyll $a$ is needed.

Dissolved-oxygen concentrations were controlled by reaeration, mechanical mixing of inflows, and organic-matter decay. Unlike Rhodhiss Lake and Lake Hickory, bottom-sediment oxygen demand in Mountain Island Lake does not appear to be a major factor in the DO balance for the reservoir. This is likely because of the short residence time; the movement of colder, oxygenated Cowans Ford inflows through the lower layers of Mountain Island Lake (as discussed subsequently); and the absence of prolonged thermal stratification in the reservoir. The relatively low algal productivity resulted in only infrequent occurrences of supersaturated DO concentrations in the surface layers of the mainstem of the reservoir. Organic-matter concentrations are controlled by external loadings of BOD and detritus and by internal loadings resulting from algal mortality. Decay rates of the organic matter, which affect water column DO concentrations, were somewhat sensitive to changes in temperature rate multipliers.
According to model simulations, algal productivity in Mountain Island Lake was limited by $\mathrm{PO}_{4}$ concentrations and light availability during the simulation period. Orthophosphorus concentrations in the photic zone were quite low during most of the year. Orthophosphorus can be released from bottom sediments when DO concentrations are less than about $1 \mathrm{mg} / \mathrm{L}$, but DO concentrations were seldom this low during the study period. Simulations of $\mathrm{PO}_{4}$ concentrations were relatively insensitive to changes in parameter-controlling phosphorus kinetics in the model because of the strong dependence of $\mathrm{PO}_{4}$ concentrations on estimates of external loading and the subsequent use of $\mathrm{PO}_{4}$ for algal production.

\section{Applications}

The calibrated Mountain Island Lake waterquality model was used to simulate selected conditions in order to describe material movement in the reservoir and to evaluate potential effects of selected future conditions. Simulations generally were performed by using boundary conditions for the 1996-97 model development period, except for a change in the 
boundary condition for which effects were evaluated. The model was applied to evaluate the following:

- Movement of a conservative, neutrally buoyant material, or tracer, through the reservoir for several sets of conditions;

- Effects of the Riverbend thermal discharge on water temperature in the reservoir;

- Effects of changes in water-supply withdrawal rates on water-quality conditions; and

- Changes in reservoir water quality in response to changes in point- and nonpoint-source loadings.

\section{Simulation of Conservative Material Transport}

The movement of a conservative, neutrally buoyant material, or tracer, in Mountain Island Lake was simulated to provide insight into travel time and dilution rates for different release scenarios. The initial concentration of the tracer was 1,000 parts per thousand (ppt) for all simulations. Release scenarios included the following:

- Short 2-hour releases at Cowans Ford Dam during summer (June 18, 1996) and winter (December 15, 1996) as an example of the potential movement of a spill through the reservoir;

- A 6-month continuous release into McDowell Creek during June-December 1996 to demonstrate the manner in which McDowell Creek water mixes and is diluted in the reservoir;

- A 6-month continuous release from the McDowell Creek WWTP during JuneDecember 1996 to demonstrate the manner in which WWTP water mixes and is diluted in the reservoir; and

- A release into McDowell Creek during stormflow conditions in July 1997 as an example of the mixing and dilution of stormflow loadings in the reservoir.

In addition, simulation results depicting the water age (the amount of time a parcel of water has been in the reservoir) are shown for selected times.

\section{Short Release at Cowans Ford Dam}

Mean discharge at Cowans Ford Dam during the simulated 2-hour June release was $237 \mathrm{~m}^{3} / \mathrm{s}$, and mean discharge during the simulated 2-hour December release was $449 \mathrm{~m}^{3} / \mathrm{s}$. Although the initial concentrations of the material released in June and December were the same, the mass of material released in December was about double the mass released in June.

Two noticeable characteristics of the simulated tracer concentrations (fig. 35) were observed at the Charlotte-Mecklenburg Utilities water-supply intake (model segment 29). First, the tracer moves more quickly during the summer, and concentrations are higher near the bottom of the reservoir than near the surface. As previously discussed, measured nearbottom water temperature in June and, therefore, density at site 14 was very nearly the same as water temperature measured at site 01 (fig. 9). The tracer simulations seem to confirm that releases from Cowans Ford Dam move along the bottom of Mountain Island Lake as a density current during the summer when the thermal gradient is greater (figs. 36 and 37). In fact, as time from the simulated June release increased, the highest concentration in the water column occurred at progressively greater depths (fig. 37A, B). Even during the winter (fig. 11A, B), when there was essentially no thermal gradient in the reservoir, the highest simulated tracer concentration was not at the water surface (fig. 37C, D). Movement of dissolved and suspended materials through the lower layers of the reservoir means that fewer nutrients are available in the nearsurface layers where algal growth occurs, thereby causing a lower potential for excessive algal production than if the material were well mixed vertically or were concentrated in the surface layers of the lake. Second, tracer concentrations pulsed (alternately increased and decreased) in response to the hydropower peaking operations at Cowans Ford Dam (figs. 35 and 36A, B). Tracer concentrations and simulated velocities suggest that water moves back upstream in a kind of sloshing or seiching motion in response to the cessation of discharge from Cowans Ford Dam.

The transport simulations of a tracer released over a brief period into Mountain Island Lake at Cowans Ford Dam (for example, a spill at U.S. Highway 73; fig. 18) demonstrate that the tracer is flushed through the reservoir more quickly during isothermal (winter) than during stratified (summer) 

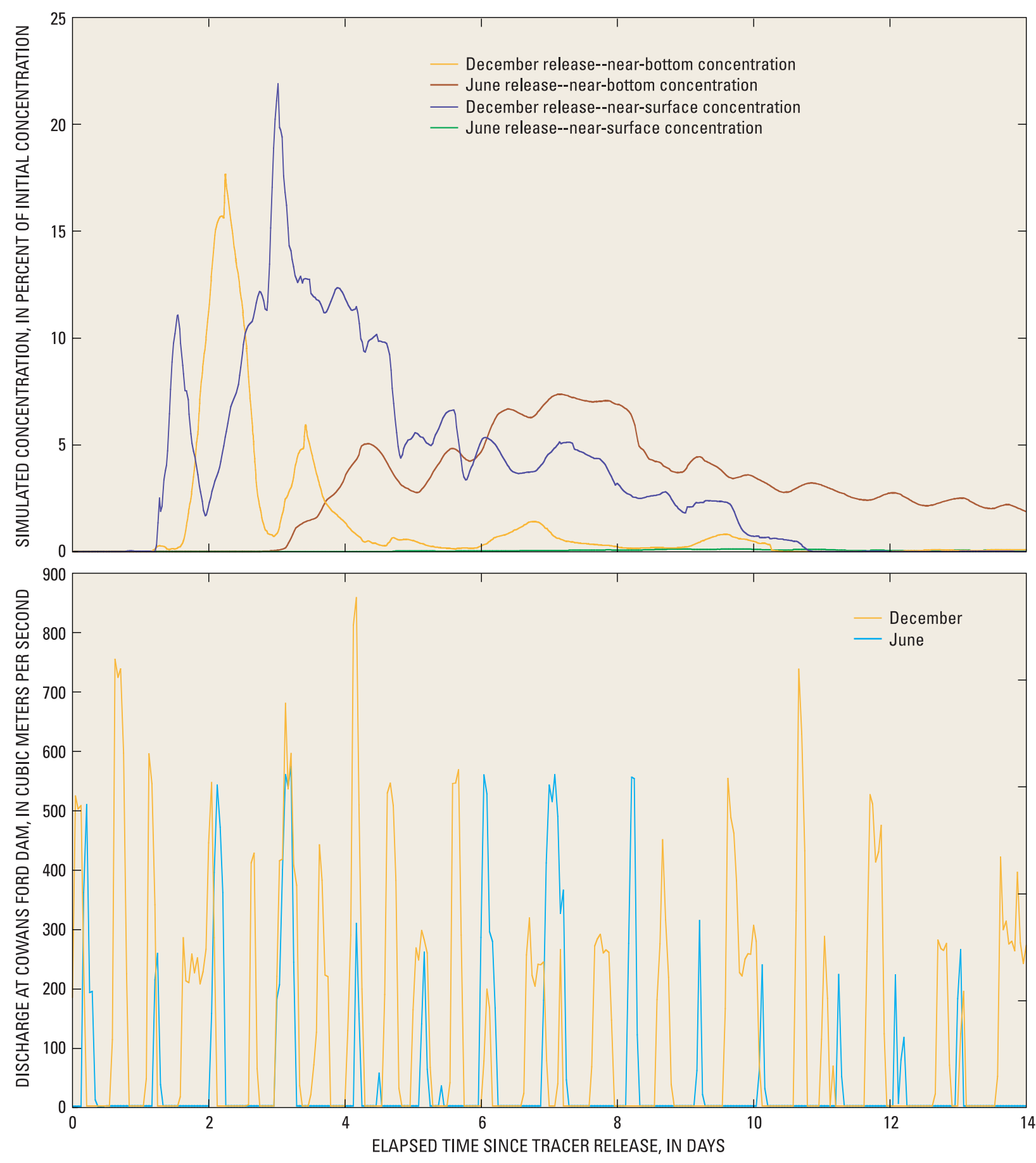

Figure 35. (A) Simulated near-surface and near-bottom concentrations of a conservative, neutrally buoyant material following a 2-hour release of the tracer at model segment 29, near the Charlotte-Mecklenburg Utilities water intake and Cowans Ford Dam for June 1996 and December 1996 conditions and (B) discharge at Cowans Ford Dam during the simulation period. 

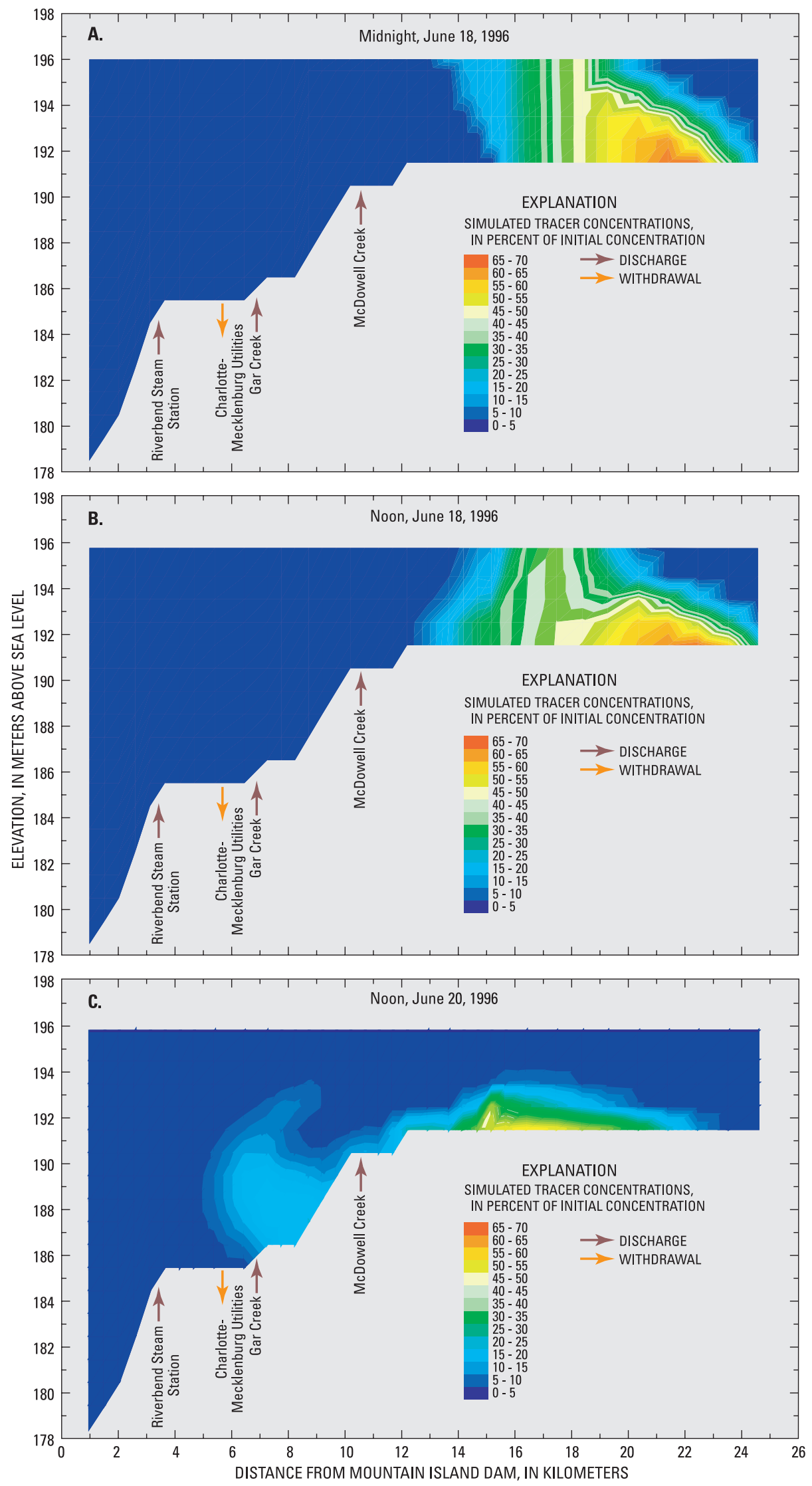

Figure 36. Simulated longitudinal and vertical distributions of a conservative, neutrally buoyant material following a 2-hour release of the tracer near Cowans Ford Dam at noon on June 17, 1996, for (A) midnight on June 18, (B) noon on June 18, and (C) noon on June 20, 1996. [Note: Contour resolution is greater than that shown in explanation color bar]. 

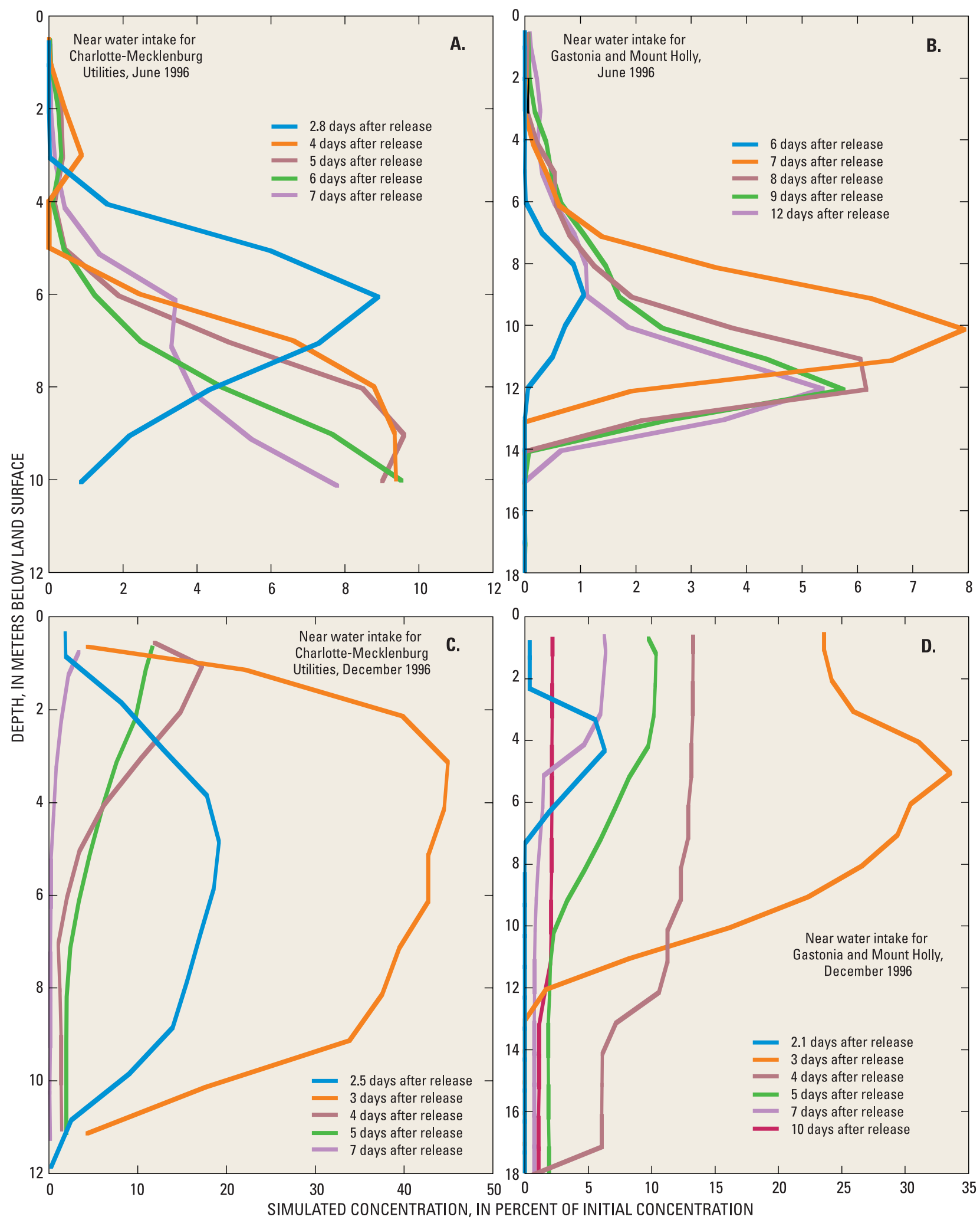

Figure 37. Simulated vertical distributions of a conservative, neutrally buoyant material following a 2-hour release of the tracer near Cowans Ford Dam for June 1996 conditions near the water intakes for (A) Charlotte-Mecklenburg Utilities and (B) Gastonia and Mount Holly, and for December 1996 conditions near the water intakes for (C) CharlotteMecklenburg Utilities and (D) Gastonia and Mount Holly. 
conditions. Under normal hydropower peaking operations, however, the concentration of the tracer near Mountain Island Dam remains greater than 1 percent of initial concentration (or $1 \mathrm{ppt}$ ) for at least 10 days (fig. 37).

\section{Continuous Release into McDowell Creek}

Transport and dilution of a tracer continuously released into McDowell Creek was simulated for the period June 18-December 31, 1996 (fig. 38). Results from the simulation demonstrate the way in which materials flowing into Mountain Island Lake from McDowell Creek are diluted and transported in the reservoir. The tracer was released at a constant concentration of 1,000 ppt. Because of the wide range in discharge in McDowell Creek (fig. 38A), however, the mass of material released varied with time.

Simulated tracer concentrations were low (less than 5 percent of the initial concentration) near the water surface in McDowell Creek cove and in the reservoir (fig. 38B, C). Near-surface concentrations in the cove were highest during the cooler months of November and December when less thermal stratification occurred in the cove.

Despite the continuous release of a constant concentration of the tracer, concentrations of the tracer in the cove and in the reservoir did not reach a steady state. However, near-bottom tracer concentrations in the cove were, on average, about 35 percent of the initial concentration, with a few higher values following high flows. Near-bottom concentrations were more variable in the reservoir than in the cove, with the highest near-bottom concentrations occurring during summer and early fall months.

\section{Continuous Release from the McDowell Creek Wastewater-Treatment Plant}

The simulated continuous tracer release from the McDowell Creek WWTP also was for the period June 18-December 31, 1996 (fig. 39). Reported discharge from the WWTP was relatively constant (between 0.09 and $0.10 \mathrm{~m}^{3} / \mathrm{s}$ ) during the period. The relative dilution and mixing of material released from the WWTP and material transported from upland areas by McDowell Creek is demonstrated by comparison of the results from this simulation and the previous simulation of a continuous release into McDowell Creek (fig. 38).

Simulated concentrations of the material released from the McDowell Creek WWTP were more evenly distributed through the water column than the McDowell Creek inflows (figs. 38B, 39A). The warmer temperature of the WWTP inflow allowed more of the material to remain at or near the water surface, unlike the McDowell Creek inflows, which were colder and more dense than the near-surface reservoir water and, thus, quickly moved to the bottom of the cove (fig. 38B). In the water-quality model, the McDowell Creek WWTP discharge enters Mountain Island Lake in model segment 40 (fig. 18), because the upstream limit of the model is the mouth of McDowell Creek. In reality, the WWTP discharge enters the creek upstream from the mouth of the creek, so some mixing of the warmer WWTP discharge and the cooler streamwater occurs in McDowell Creek before the WWTP discharge enters the lake.

Simulated concentrations of WWTP discharge material in McDowell Creek cove generally were less than 2 percent of the initial concentration. This means that the WWTP discharge is diluted 50 to 100 times in the cove. By the time the material reaches the Charlotte-Mecklenburg Utilities and the GastoniaMount Holly water-supply intakes, the WWTP discharge is diluted about 200 to 1,000 times in the lake. These dilution factors do not account for settling or for chemical and biological processes that further reduce concentrations of the WWTP discharge. The relatively uniform vertical distribution of the tracer simulated for McDowell Creek cove is maintained in the reservoir, where near-surface concentrations are about one-half of near-bottom concentrations.

Although the initial concentration was the same for both simulations, concentrations of tracer released with the WWTP discharge are about 20 to 50 times lower in McDowell Creek cove than concentrations of tracer entering the cove by way of McDowell Creek, because flows are lower from the WWTP than in the stream.

\section{Release During McDowell Creek High-Flow Event}

In order to demonstrate the potential effects of individual storm events on Mountain Island water quality, the transport and mixing of a tracer released into McDowell Creek over a 2-day period during July 22-23, 1997, was simulated. The McDowell Creek Basin received more than $10 \mathrm{~cm}$ of rain during the storm, which resulted in greater than 100-year flooding in parts of Charlotte (Robinson, Hazell, and Young, 1998). In the simulation, the tracer was released at a constant concentration of $1,000 \mathrm{ppt}$ during the 2-day period. 

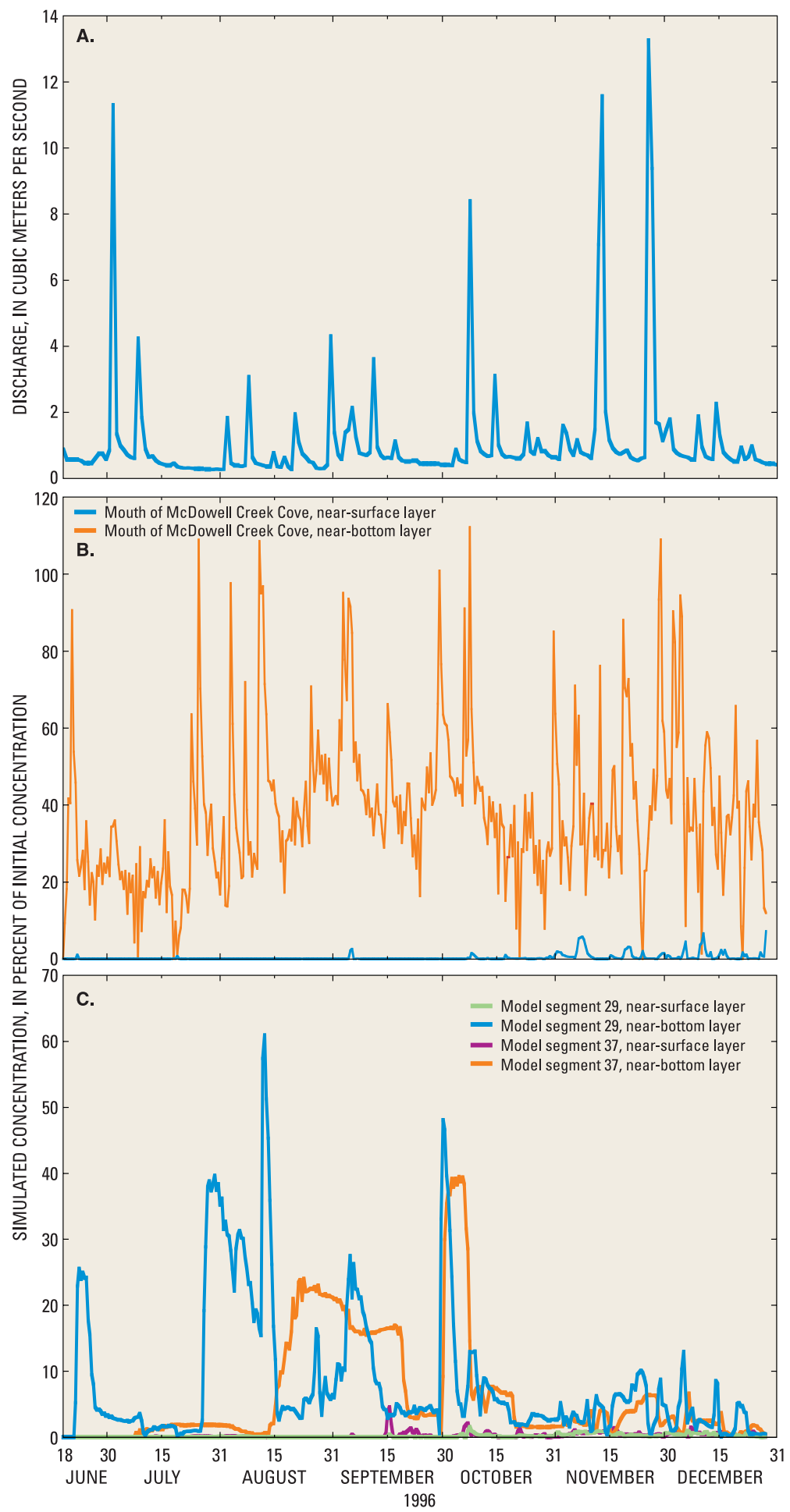

Figure 38. (A) Estimated daily mean discharge at the mouth of McDowell Creek, June 18-December 31, 1996; (B) simulated nearsurface and near-bottom conservative tracer concentrations near the mouth of McDowell Creek cove (model segment 42); and (C) simulated near-surface and near-bottom conservative tracer concentrations near the water intakes for Charlotte-Mecklenburg Utilities (segment 29) and Gastonia and Mount Holly (segment 37) for a continuous tracer release into McDowell Creek. 


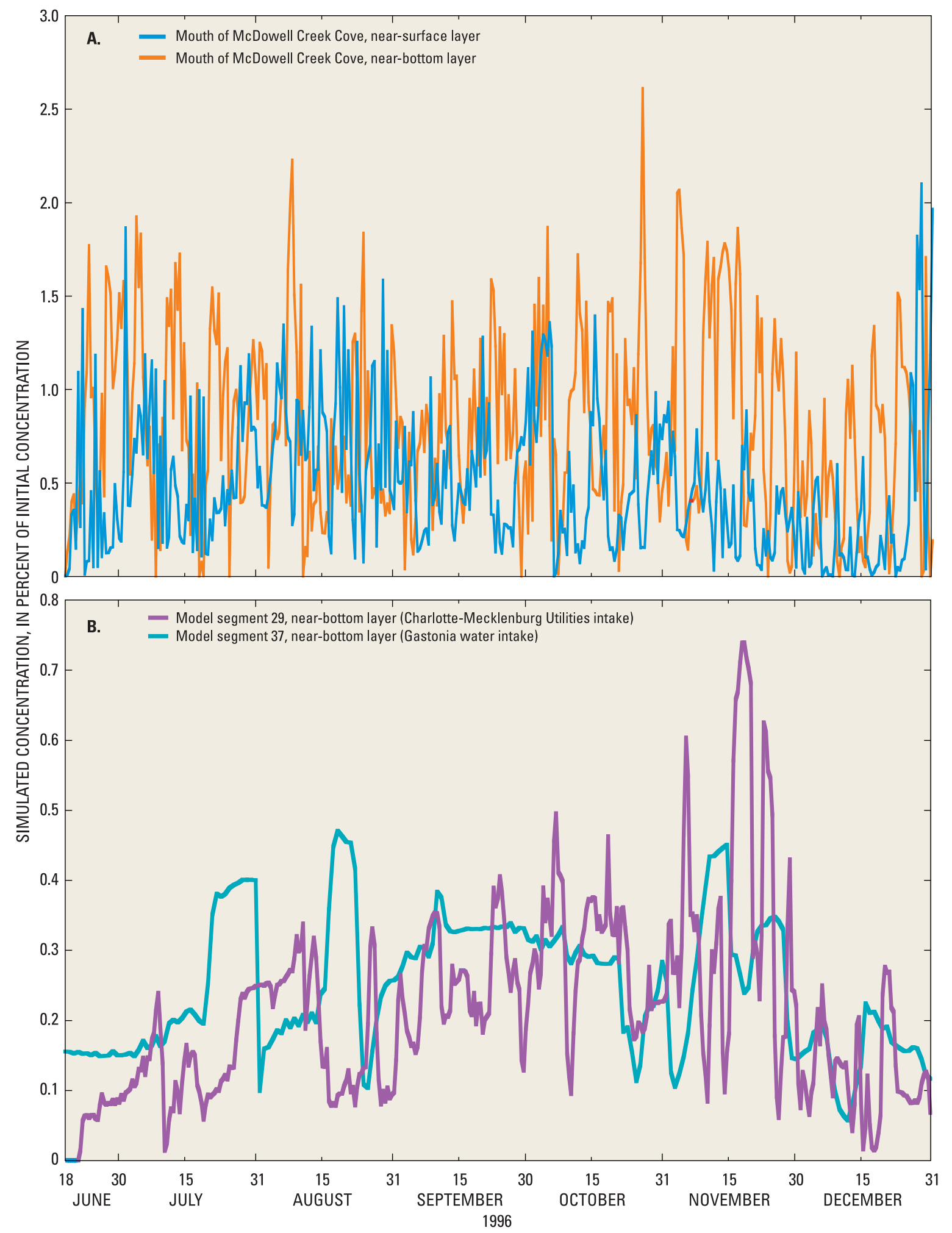

Figure 39. (A) Simulated near-surface and near-bottom conservative tracer concentrations near the mouth of McDowell Creek cove (model segment 42); and (B) near-bottom conservative tracer concentrations near the water intakes for Charlotte-Mecklenburg Utilities (segment 29) and Gastonia and Mount Holly (segment 37) for a continuous tracer release from the McDowell Creek Wastewater-Treatment Plant during June 18December 31, 1996. 
During the storm when McDowell Creek flows were elevated (estimated peak discharge of $27 \mathrm{~m}^{3} / \mathrm{s}$ at the mouth), near-bottom tracer concentrations in McDowell Creek cove essentially were undiluted from the inflow concentration (fig. 40). As flow in McDowell Creek returned to more normal conditions, near-bottom tracer concentrations in McDowell Creek cove quickly dropped to less than 1 percent of the initial concentration. The results suggest that material transported into the cove by McDowell Creek during large storm events is not retained in the cove but moves quickly into the mainstem of the reservoir.

The tracer did not reach the downstream end of the reservoir until about 6 days after the beginning of the storm (fig. 40). The characteristic pulsing of tracer concentrations associated with hydropower operations (for example, fig. 35, as previously discussed) also is evident during this event. Near-bottom tracer concentrations reached a maximum of about 20 percent of the initial concentration (or was diluted to about onefifth the original concentration) 2 weeks after the beginning of the storm. Simulated near-bottom tracer concentrations at the dam remained at greater than
10 percent of the initial concentration for at least a month after the storm event. These results indicate that large storm events can have fairly long-lasting effects on Mountain Island Lake water quality, despite the apparent short theoretical residence time of the reservoir.

As with the previously discussed simulations of conservative material transport, the highest simulated concentrations were near the reservoir bottom. This means that, although storm-related inflows of nutrients from McDowell Creek may be relatively undiluted during transport through the reservoir and the material can persist in the reservoir for more than a month after a storm during typical summer conditions, the nutrients generally are unavailable to algal production in the photic zone. In fact, for this particular simulation, tracer concentrations in the upper $3 \mathrm{~m}$ of the reservoir near the dam essentially were zero. Nevertheless, nutrients are not conservative, and biochemical processes (as well as settling of particulate matter) other than simple dilution occur as the nutrients move through the reservoir.

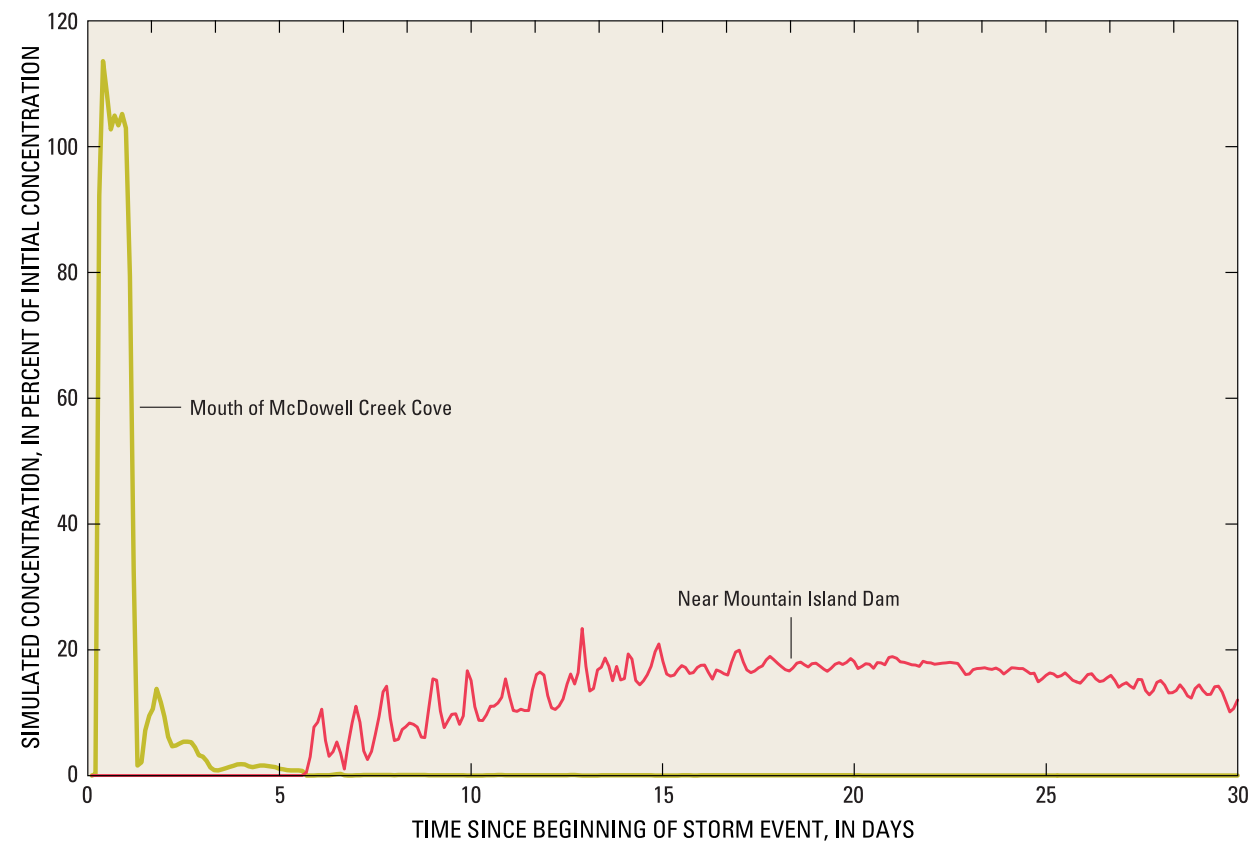

Figure 40. Simulated near-bottom conservative tracer concentrations near the mouth of McDowell Creek cove (model segment 42), and near water intakes for Mountain Island Dam and Gastonia and Mount Holly (segment 37) for a 2-day continuous tracer release into McDowell Creek during the July 22-23, 1997, storm. 


\section{Water-Age Simulation}

Simulations of the age of water, or amount of time a parcel of water has been in the reservoir, provide insight into mixing characteristics and residence times. Water age was simulated for summer (July 26, 1996; fig. 41A) and winter (February 20, 1997; fig. 41B) conditions. On July 26, 1996, some of the water had been in the reservoir more than 30 days, but the youngest water was in the riverine part of the reservoir and near the bottom of the reservoir at distances of about 4 to $12 \mathrm{~km}$ from the dam (fig. 41A). Water in the downstreammost $12 \mathrm{~km}$ of the reservoir and in the upper 2-6 $\mathrm{m}$ was retained longer than water near the bottom over most of this reach. The pool of younger water near the water surface, particularly evident for the summer simulation (fig. 41A), and within about $2-7 \mathrm{~km}$ of the dam is water discharged from the Riverbend Steam Station. Apparently, water in the very deepest part of the reservoir near the dam is trapped with very little circulation during the summer. In the winter (fig. 41B), the oldest water in the lake is less than 15 days old, or very nearly the theoretical

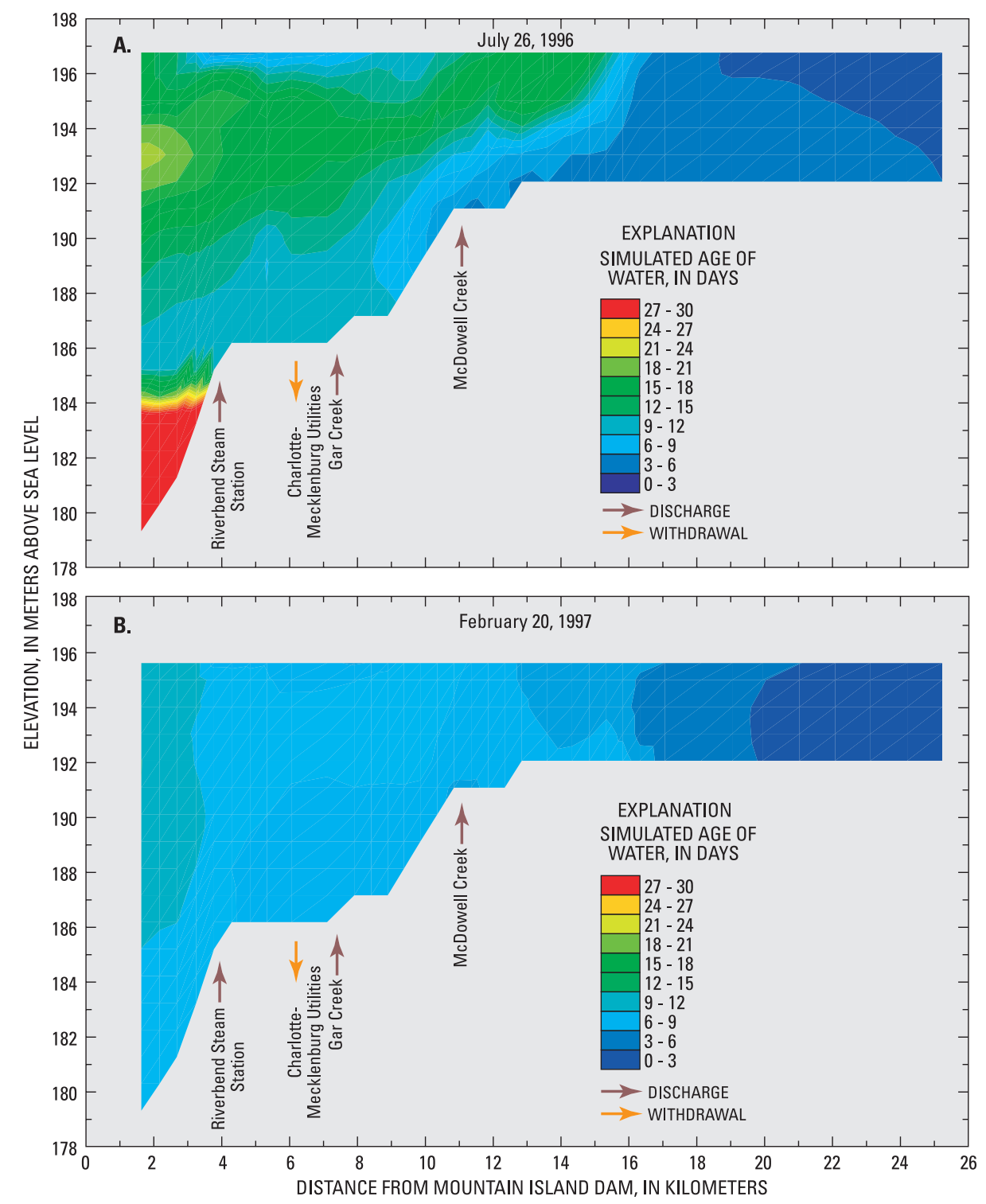

Figure 41. Simulated Mountain Island Lake water age for (A) July 26, 1996, and

(B) February 20, 1997. [Note: Contour resolution is greater than that shown in explanation color bar]. 
hydraulic residence time of the lake. The summer simulations demonstrate, however, that the term "residence time" can be misleading.

\section{Simulation of Effects of Thermal Discharge}

Water temperature in Mountain Island Lake was simulated for 1996-97 observed conditions, except the Riverbend Steam Station withdrawal and thermal discharge rates were both assumed to be zero. This simulation demonstrates the effects of the Riverbend Steam Station in the thermal structure of Mountain Island Lake. Simulations indicate that the laterally averaged near-surface water temperatures in model segment 33, in which the thermal discharge is located (fig. 18), were increased by as much as $8.5^{\circ} \mathrm{C}$ by the presence of the thermal discharge relative to conditions without the discharge (fig. 42A). During the entire April 1996-October 1997 simulation period, the mean difference at site 14 between the existing conditions and the conditions with no thermal discharge nearsurface water temperatures was $2{ }^{\circ} \mathrm{C}$, and the median difference was $1.6^{\circ} \mathrm{C}$. Daily to weekly variations in near-surface water temperature also were increased by the presence of the thermal discharge (fig. 42A).

The presence of the thermal discharge had less of an effect on near-bottom water temperatures (fig. 42B), where the maximum temperature increase was $2.2{ }^{\circ} \mathrm{C}$ and the mean temperature difference between the with and without thermal-discharge conditions was $0.4{ }^{\circ} \mathrm{C}$. About $1.6 \mathrm{~km}$ downstream from the thermal discharge in model segment 36 near Mountain Island Dam (fig. 18), the effects of the thermal discharge on nearsurface water temperature were still evident during some periods (fig. 42C). Near-surface water temperatures in segment 36 were increased by as much as $5{ }^{\circ} \mathrm{C}$ during the study period by the presence of the thermal discharge, but the mean increase was about $0.7^{\circ} \mathrm{C}$.

The results of the simulation for near-surface conditions in model segment 33 , by virtue of the model structure, are for the average water temperature over a volume of water that is $1 \mathrm{~m}$ thick (thickness of computational layer; fig. 19), $510 \mathrm{~m}$ long (length of segment 33), and about $670 \mathrm{~m}$ wide (average nearsurface width of segment 33). Water-temperature changes in the immediate vicinity of the thermal discharge could be evaluated better by using a nearfield mixing model.

\section{Simulation of Effects of Increased Water-Supply Withdrawals}

Charlotte-Mecklenburg Utilities has proposed doubling the capacity of the water-supply intake in Mountain Island Lake to about $14.5 \mathrm{~m}^{3} / \mathrm{s}$. The effects of this increased withdrawal on water quality in Mountain Island Lake were simulated by establishing a constant withdrawal rate of $14.5 \mathrm{~m}^{3} / \mathrm{s}$ for the 1996-97 simulation period and increasing Cowans Ford inflows by the same rate so that water levels in Mountain Island Lake would be unchanged from measured 1996-97 conditions.

Simulations of water-quality conditions for the increased withdrawal did not change appreciably from simulations for existing 1996-97 conditions. Water temperature, chlorophyll $a$ concentrations, and DO concentrations in the mainstem of the reservoir essentially were the same for both sets of conditions (existing and increased withdrawal). The simulated withdrawal rate of $14.5 \mathrm{~m}^{3} / \mathrm{s}$ is almost three times the withdrawal rate reported for the study period. It is likely that flow patterns in the vicinity of the intake would be affected by the withdrawal, but a more spatially refined hydraulic model is required to evaluate such effects.

\section{Simulation of Effects of Changes in Chemical Loads}

Degradation of Lake Norman water quality and continued development in the McDowell Creek Basin could have an adverse effect on Mountain Island Lake water quality by increasing chemical loads to the lake. The effects of changes in external constituent loads were simulated by using the calibrated water-quality model. First, concentrations of total suspended solids, dissolved and suspended organic matter, $\mathrm{NO}_{3}, \mathrm{NH}_{4}$, $\mathrm{PO}_{4}$, and BOD in flows through Cowans Ford Dam were increased by 20 percent, while all other conditions were the same as measured during the 1996-97 study. In the second scenario, concentrations of total suspended solids, dissolved and suspended organic matter, $\mathrm{NO}_{3}, \mathrm{NH}_{4}, \mathrm{PO}_{4}$, and $\mathrm{BOD}$ in McDowell Creek inflows were increased by 20 percent, with no change to other conditions. A 20-percent increase in concentration and no change in flows leads to a 20-percent increase in load relative to the 1996-97 conditions (table 11).

Maximum simulated chlorophyll $a$ concentrations in McDowell Creek cove during the spring of 1996 were increased about the same amount 

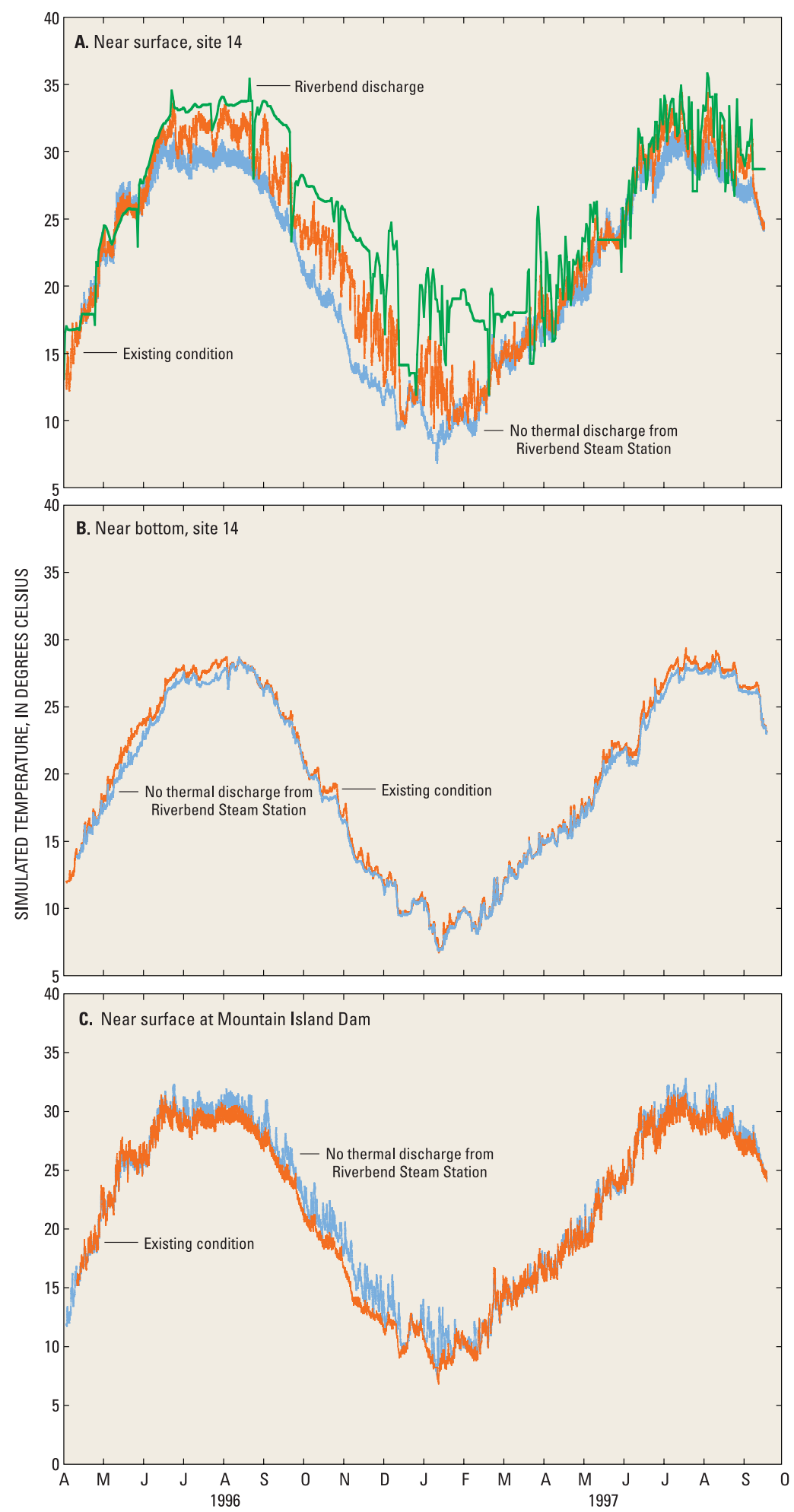

Figure 42. Simulated (A) near-surface and (B) near-bottom water temperature at site 14 (near the Riverbend Steam Station thermal discharge), and (C) near-surface water temperature at Mountain Island Dam. 
by increased loadings from Cowans Ford Dam as by increased loadings from McDowell Creek (fig. 43A). During the summer of 1996 and the spring and summer of 1997, simulated chlorophyll $a$ concentrations in the cove were increased more by the increases in loads from Cowans Ford Dam than by increases from McDowell Creek. One possible reason for the lower increases in chlorophyll $a$ concentrations in the cove as a result of increased loadings from McDowell Creek is that along with higher $\mathrm{PO}_{4}$ concentrations came much higher sediment concentrations, which would reduce light availability and thereby limit algal production.

Results were somewhat similar for simulated chlorophyll $a$ concentrations in the mainstem of the

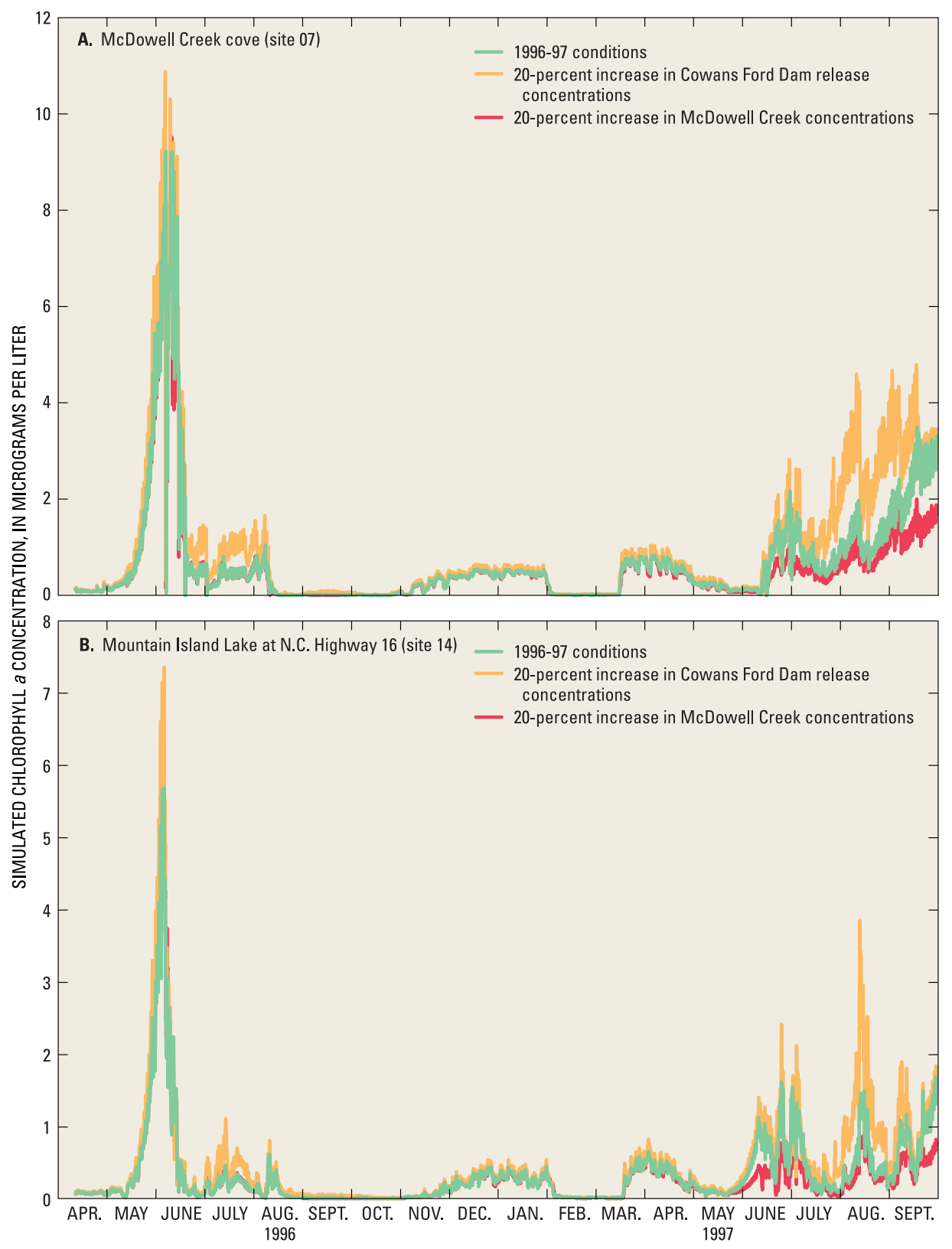

Figure 43. Simulated chlorophyll a concentrations for 1996-97 conditions, a 20-percent increase in concentrations of selected constituents in Cowans Ford releases, and a 20-percent increase in concentrations of selected constituents in McDowell Creek inflows for (A) McDowell Creek cove and (B) Mountain Island Lake site 14. 
reservoir at site 14 (fig. 43B). Increased loadings from Cowans Ford Dam had a greater effect on chlorophyll $a$ concentrations in the reservoir during 1997. The 20-percent increase in loads through Cowans Ford Dam led to almost a doubling of chlorophyll $a$ relative to the base, or original 1996-97 conditions, during the spring and summer of 1997.

Simulated near-bottom DO concentrations in the mainstem of the reservoir were affected only slightly by the increased loadings (fig. 44), but there were more occurrences of DO concentrations less than $5 \mathrm{mg} / \mathrm{L}$ with the increased loadings. At times, near-bottom DO concentrations were increased-possibly because of increased algal photosynthesis. At other times, nearbottom DO concentrations decreased-probably because of increased organic matter and BOD loading.

Stormwater loadings from McDowell Creek affect DO concentrations in Mountain Island Lake during the summer. One of the highest peak discharges - estimated at be $97 \mathrm{~m}^{3} / \mathrm{s}$ - at the mouth of McDowell Creek during the study period occurred at 7:00 p.m. on July 25, 1996. As a result of the high discharge, simulated suspended solids concentrations in McDowell Creek cove were as high as $900 \mathrm{mg} / \mathrm{L}$, with the highest concentrations at the bottom.
Maximum simulated particulate organic matter concentrations were about $150 \mathrm{mg} / \mathrm{L}$ in the cove. Simulated suspended solids concentrations in the upper $2 \mathrm{~m}$ of the water column in the cove were less than $100 \mathrm{mg} / \mathrm{L}$. The suspended solids were flushed from the cove fairly quickly, however, and within 2 days of the storm, simulated suspended solids concentrations in the cove were less than $5 \mathrm{mg} / \mathrm{L}$.

The suspended solids load and associated organic matter from the July 25 storm entered Mountain Island Lake and moved downstream along the bottom of the reservoir, with some expansion of the plume as the material moved toward the dam (fig. 45A-C). A delayed, but definite, response in DO concentrations occurred in the lake to the increased loading of organic matter (fig. 45D-F), with a reduction of near-bottom DO concentrations from about $4 \mathrm{mg} / \mathrm{L}$ prior to the storm to less than $2 \mathrm{mg} / \mathrm{L}$ over an area that was about $4 \mathrm{~km}$ long and about $2 \mathrm{~m}$ thick. These conditions persisted for at least 2 weeks.

These simulations illustrate several important points, some of which have been mentioned before. During stormflow conditions, loadings from McDowell Creek can have a noticeable effect on McDowell Creek cove and Mountain Island Lake.

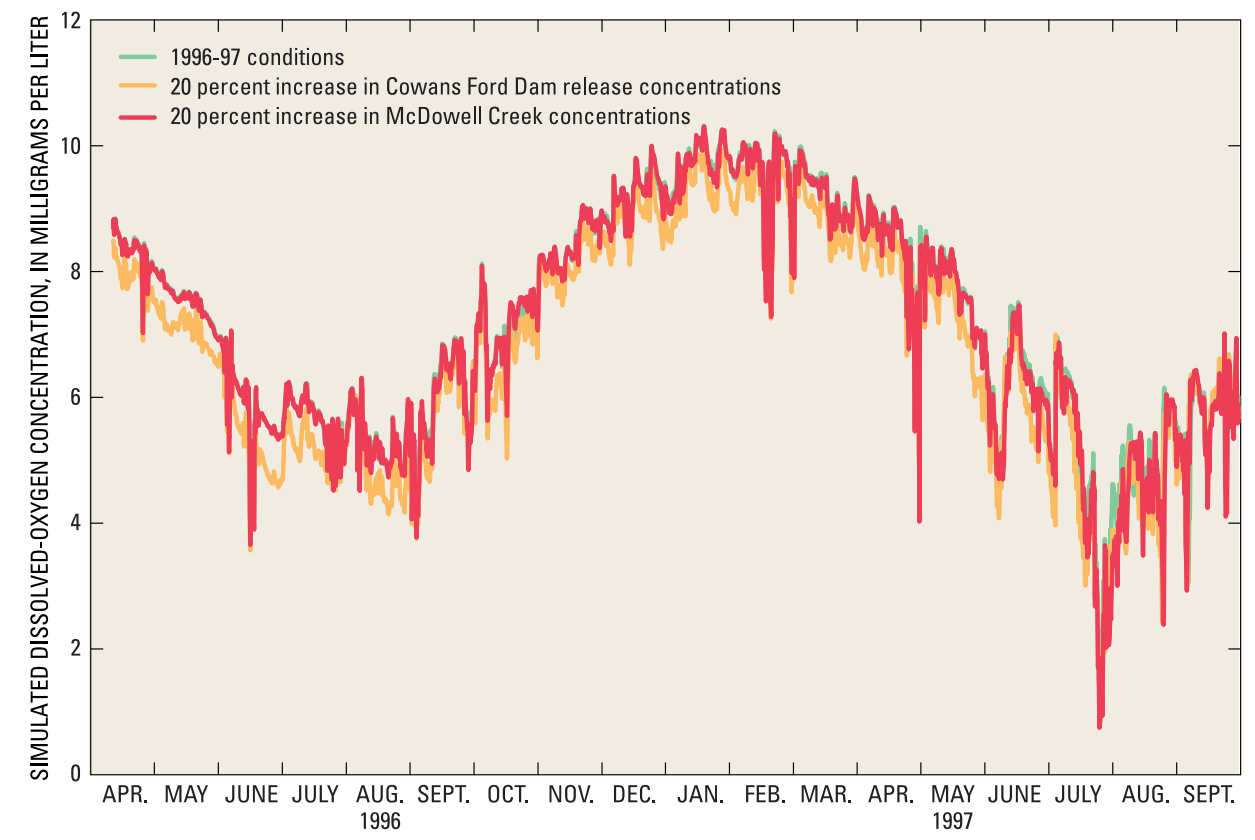

Figure 44. Simulated near-bottom dissolved-oxygen concentrations for 1996-97 conditions, a 20-percent increase in concentrations of selected constituents in Cowans Ford releases, and a 20-percent increase in concentrations of selected constituents in McDowell Creek inflows for Mountain Island Lake site 14. 

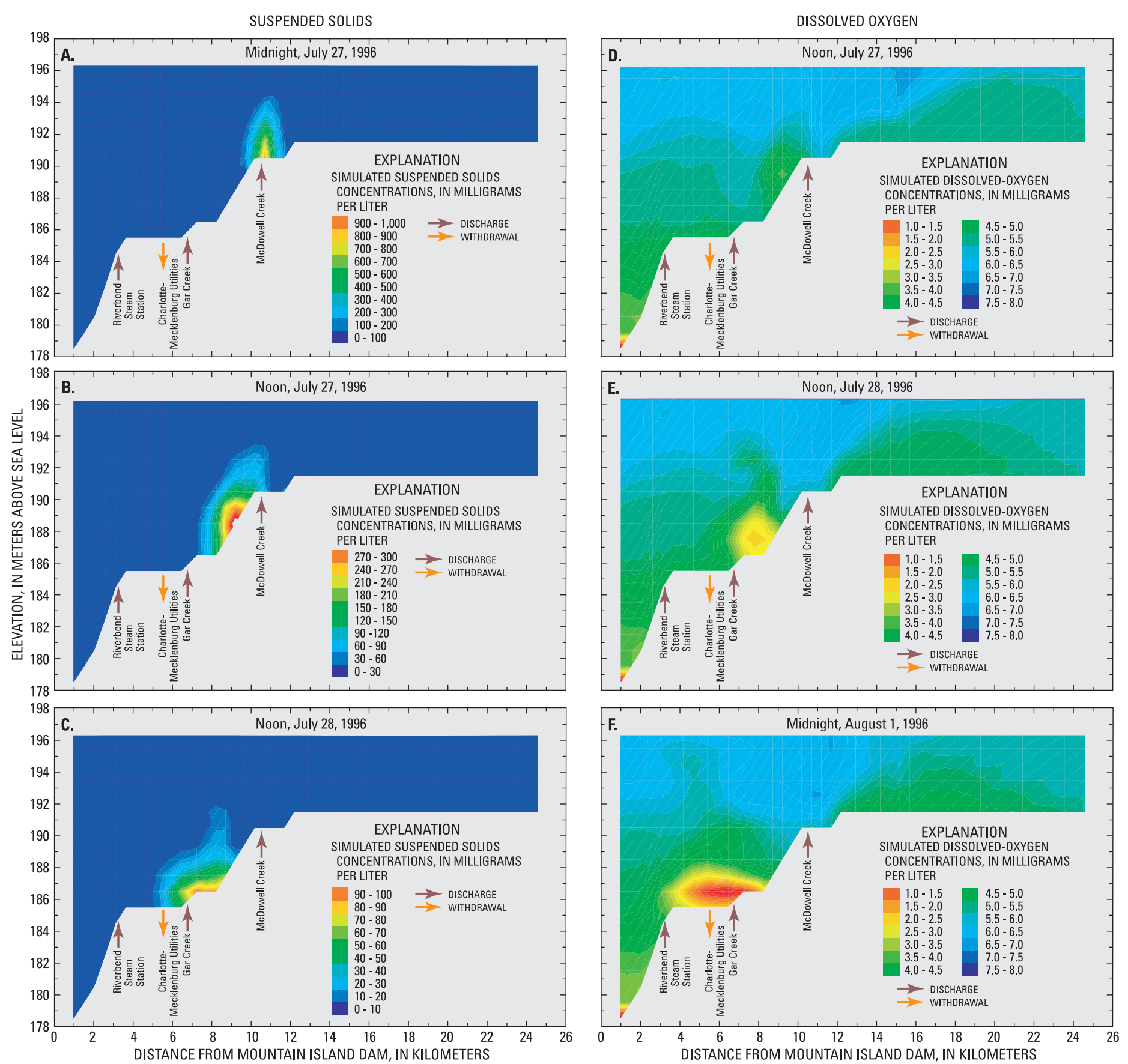

Figure 45. Simulated suspended solids concentrations in Mountain Island Lake for (A) midnight on July 27, 1996; (B) noon on July 27, 1996; (C) noon on July 28, 1996; and simulated dissolved-oxygen concentrations for (D) noon on July 27, 1996; (E) noon on July 28, 1996; and (F) midnight on August 1, 1996. [Note: Contour resolution is greater than that shown in explanation color bar.] 
However, material is flushed from McDowell Creek within a few days and, during warm months, moves through Mountain Island Lake along the bottom. The greatest effect of stormflows in McDowell Creek appears to be on DO concentrations in the lake, where effects can persist for weeks.

\section{SUMMARY AND CONCLUSIONS}

During 1994-97, the USGS, in cooperation with Charlotte-Mecklenburg Utilities, conducted an investigation of Mountain Island Lake to characterize hydrologic and water-quality conditions and to develop tools to simulate the effects of changes in external conditions on reservoir water quality. Water levels, streamflow, and water quality were monitored, and circulation and water-quality processes in Mountain Island Lake were simulated by using the U.S. Army Corps of Engineers' CE-QUAL-W2 model.

Hydrologic data included water-level measurements in the reservoir and dam release records from Cowans Ford Dam and Mountain Island Dam. Physical water-quality characteristics included water temperature, dissolved-oxygen (DO) concentration, specific conductance, and $\mathrm{pH}$ measured at 15 sites located in the mainstem and several coves of Mountain Island Lake and at a site on the Catawba River downstream from Mountain Island Dam. In addition, concentrations of a suite of chemical constituents were determined from samples collected at eight sites. These data, as well as meteorological data, were used to describe conditions in the reservoir and to calibrate and apply the water-quality model.

Mountain Island Lake levels fluctuated widely, typically exhibiting one or more daily peaks in response to discharge from Cowans Ford Dam. During October 1995-September 1997, daily water-level fluctuations at the Catawba River site at U.S. Highway 73 (site 01 ) ranged from 0.32 to $2.73 \mathrm{~m}$, with a median daily fluctuation of $0.92 \mathrm{~m}$. Water levels at the Mountain Island Lake site at N.C. Highway 16 (site 14) varied less than at site 01 , with daily fluctuations ranging from $0.08 \mathrm{~m}$ to $0.98 \mathrm{~m}$. During October 1995September 1997, the median daily water-level fluctuation at site 14 was $0.31 \mathrm{~m}$. Water-level peaks at site 14 generally lagged those at site 01 by about 1 to 4 hours, depending on the magnitude and duration of discharge from Cowans Ford Dam

Flows into Mountain Island Lake are dominated by water releases through Cowans Ford Dam, with more than 85 percent of the total inflow to the reservoir coming from Lake Norman through the dam. Riverbend Steam Station cooling-water discharges accounted for about 12 percent of the inflows to the reservoir, and inflows from tributary streams contributed less than 1.5 percent of total inflows. Releases through Mountain Island Dam accounted for about 81 percent of withdrawals from the reservoir, while Riverbend Steam Station withdrawals, which were equal to discharge from the facility, constituted about 13 percent of the reservoir withdrawals. About 5.5 percent of the withdrawals were for water supply.

Thermal stratification in Mountain Island Lake during April 1996-September 1997 typically was fairly weak. The Riverbend Steam Station thermal discharge, however, had a pronounced effect on surface-water temperatures near the outfall. As a result of the weak thermal stratification in the lake, DO concentrations only infrequently were less than $4 \mathrm{mg} / \mathrm{L}$ and seldom less than $5 \mathrm{mg} / \mathrm{L}$ throughout the entire reservoir, including the coves.

During April 1996-September 1997, concentrations of nitrate $\left(\mathrm{NO}_{3}\right)$, ammonia $\left(\mathrm{NH}_{4}\right)$, total phosphorus (TP), and chlorophyll $a$ were higher in the McDowell Creek cove than elsewhere throughout the reservoir. Nevertheless, the highest chlorophyll $a$ concentration measured during the study was $13 \mu \mathrm{g} / \mathrm{L}$, well below the North Carolina ambient water-quality standard of $40 \mu \mathrm{g} / \mathrm{L}$. In the mainstem of the reservoir, near-bottom $\mathrm{NH}_{4}$ concentrations were occasionally greater than near-surface concentrations. However, the relatively large top-to-bottom differences in $\mathrm{NH}_{4}$ and phosphorus that have been observed previously in other Catawba River reservoirs were not present in Mountain Island Lake.

The two-dimensional, laterally averaged model CE-QUAL-W2 was applied to Mountain Island Lake. The model was configured to simulate water level, water temperature, and 12 water-quality constituents. The model included the mainstem, four coves, three point-source discharges, and three withdrawals.

The mainstem of the reservoir is represented by 36 computational segments, and each of the embayments is represented by at least 3 segments. Segments range in length from 420 to $1,140 \mathrm{~m}$, with longer segments typically located in the upstream, more riverine reach of the reservoir. Layers within each segment are $1 \mathrm{~m}$ thick.

As part of model development, external loadings of suspended solids, nitrogen, phosphorus, and 
biochemical oxygen demand (BOD) to the reservoir were determined for May 1996-April 1997. Flows through Cowans Ford Dam contributed more than 80 percent of the BOD and nitrogen load to the reservoir, with McDowell Creek contributing about 15 percent of the BOD load. Phosphorus loadings were contributed to the reservoir by McDowell Creek (about 50 percent), inflows through Cowans Ford Dam (about 25 percent), and the McDowell Creek WastewaterTreatment Plant (about 15 percent).

Simulated water levels generally were within $10 \mathrm{~cm}$ of measured values, indicating a good calibration of the water balance for the reservoir. The root-mean-square difference between measured and simulated water temperatures was about $1{ }^{\circ} \mathrm{C}$, and vertical distributions of water temperature were accurately simulated in both the mainstem and coves.

Seasonal and spatial patterns of $\mathrm{NO}_{3}, \mathrm{NH}_{4}$, orthophosphorus $\left(\mathrm{PO}_{4}\right)$, and chlorophyll $a$ were reasonably reproduced by the water-quality model. Probably because of the absence of the denitrification process in the model formulation, $\mathrm{NO}_{3}$ concentrations typically were overpredicted. Simulated and measured $\mathrm{NH}_{4}$ concentrations seldom differed by more than $0.01 \mathrm{mg} / \mathrm{L}$, and simulations of seasonal fluctuations in chlorophyll $a$ were representative of measured conditions. The root-mean-square difference between measured and simulated DO concentrations was $0.7 \mathrm{mg} / \mathrm{L}$ for the near-surface layer and $1.1 \mathrm{mg} / \mathrm{L}$ for the near-bottom layer at site 14 .

The calibrated water-quality model was applied to evaluate the movement of a conservative, neutrally buoyant material, or tracer, through the reservoir for several sets of conditions. In addition, the model was used to evaluate the effects of the Riverbend Steam Station thermal discharge on water temperature in the reservoir, the effect of proposed doubling in watersupply withdrawal rates on water-quality conditions, and changes in reservoir water quality in response to two possible scenarios of changes in nonpoint-source loadings.

In general, simulations indicate that dissolved material entering Mountain Island Lake from both Cowans Ford Dam and McDowell Creek during the summer moves along the bottom of the lake toward Mountain Island Dam with little mixing of dissolved material into the surface layers. Simulations suggest that dissolved material can move upstream in the reservoir when flows from Cowans Ford Dam are near zero, and under some conditions, dissolved material can remain in Mountain Island Lake for a period longer than the theoretical retention time of 12 days. Even during the winter when there essentially was no thermal gradient in the reservoir, the highest simulated tracer concentrations were not near the water surface. Movement of inflowing water containing dissolved and suspended materials through the lower layers of the reservoir suggests that fewer nutrients are available in the near-surface layers where algal growth occurs, thereby causing a lower potential for excessive algal production than if the material were well mixed vertically or were concentrated in the surface layers of the lake.

Simulations indicate that the Riverbend thermal discharge increases water temperature in the surface layers of the downstream part of the reservoir by an average of about $2{ }^{\circ} \mathrm{C}$. The discharge, however, has little effect on near-bottom water temperature.

Simulations also indicate that a proposed doubling of the water-supply withdrawals from Mountain Island Lake has no readily apparent effect on water quality in the reservoir. The increased withdrawal rate may have some localized effects on circulation in the reservoir, but a more detailed model of the intake zone is required to identify possible effects.

The effects of a 20-percent increase in waterchemistry loadings from both Cowans Ford Dam and McDowell Creek were simulated by increasing concentrations of all influent chemical constituents by 20 percent. Increased loadings from Cowans Ford Dam had about the same effect on water-quality conditions near Mountain Island Dam as did increased loadings from McDowell Creek. Maintenance of the good water quality in Mountain Island Lake is dependent on good water quality in Lake Norman as well as the quality of the inflows from the McDowell Creek watershed.

\section{SELECTED REFERENCES}

American Public Health Association, American Water Works Association, and Water Environment Federation, 1992, Standard methods for the examination of water and wastewater (18th ed.): Washington, D.C., American Public Health Association, American Water Works Association, and Water Environment Federation, 981 p.

Bales, J.D., and Childress, C.J.O., 1999, Water-quality indices as measures of reservoir water quality in North Carolina: Raleigh, N.C., Water Resources Research Institute of The University of North Carolina, Institute Proceedings No. 12, p. 7. 
Bales, J.D., and Giorgino, M.J., 1998, Lake Hickory, North Carolina-Analysis of ambient conditions and simulation of hydrodynamics, constituent transport, and water-quality characteristics, 1993-94: U.S. Geological Survey Water-Resources Investigations Report 98-4149, 62 p.

Bales, J.D., Weaver, J.C., and Robinson, J.B., 1999, Relation of land use to streamflow and water quality at selected sites in the City of Charlotte and Mecklenburg County, North Carolina, 1993-98: U.S. Geological Survey Water-Resources Investigations Report 99-4180, 95 p.

Caldwell, W.S., 1992, Selected water-quality and biological characteristics of streams in some forested basins of North Carolina, 1985-88: U.S. Geological Survey Water-Resources Investigations Report 92-4129, $114 \mathrm{p}$.

Cole, T.M., and Buchak, E.M., 1995, CE-QUAL-W2-A two-dimensional, laterally averaged, hydrodynamic and water quality model, version 2.0, user manual: Vicksburg, Miss., Instruction Report EL-95-1, U.S. Army Engineer Waterways Experiment Station, 57 p. + app.

Eddins, W.H., and Crawford, J.K., 1984, Reconnaissance of water-quality characteristics of streams in the City of Charlotte and Mecklenburg County, North Carolina: U.S. Geological Survey Water-Resources Investigations Report 84-4308, 105 p.

Fusilier, W., 1982, An opinion derived nine parameter unweighted multiplicative lake quality index-The LWQI: Ann Arbor, Mich., University of Michigan, Department of Environmental Health Sciences, unpublished Ph.D. dissertation, 76 p.

Giorgino, M.J., and Bales, J.D., 1997, Rhodhiss Lake, North Carolina-Analysis of ambient conditions and simulation of hydrodynamics, constituent transport, and water-quality characteristics, 1993-94: U.S. Geological Survey Water-Resources Investigations Report 97-4131, 62 p.

Hem, J.D., 1970, Study and interpretation of the chemical characteristics of natural water: U.S. Geological Survey Water-Supply Paper 1473, 363 p.

Hershfield, D.M., 1961, Rainfall frequency atlas of the United States: Washington, D.C., Department of Commerce, Weather Bureau, Technical Paper No. 40, $114 \mathrm{p}$.

Hughes, W.B., 1994, National Water-Quality Assessment Program-The Santee River Basin and coastal drainages, N.C. and S.C.: U.S. Geological Survey Fact Sheet 94-010, 2 p.

Jaynes, M.L., 1994, Hydrologic, water-quality, and meteorologic data from selected sites in the upper Catawba River Basin, North Carolina, January 1993 through March 1994: U.S. Geological Survey OpenFile Report 94-509, 76 p.
LeGrand, H.E., and Mundorff, M.J., 1952, Geology and groundwater in the Charlotte area, North Carolina: North Carolina Department of Conservation and Development, Bulletin 63, 88 p.

Maluk, T.L., and Kelley, R.E., 1997, Pesticides in surface waters of the Santee River Basin and coastal drainages, North and South Carolina: U.S. Geological Survey Fact Sheet FS-007-98, 6 p.

Maluk, T.L., Reuber, E.J., and Hughes, W.B., 1998, Nutrients in waters of the Santee River Basin and coastal drainages, North and South Carolina, 1973-93: U.S. Geological Survey Water-Resources Investigations Report 97-4172, 60 p.

McCachren, C.M., 1980, Soil survey of Mecklenburg County, North Carolina: U.S. Department of Agriculture, Soil Conservation Service, 97 p.

Mecklenburg County Department of Environmental Protection, 1992, State of the environment, 1991: Charlotte, N.C., Mecklenburg County, 133 p. 1995, McDowell Creek basin study, 1993-94: Charlotte, N.C., Mecklenburg County, 6 p. 2000, State of the environment report, 2000: Charlotte, N.C., City of Charlotte and Mecklenburg County, 130 p. + app.

National Oceanic and Atmospheric Administration, 1997, Climatological data annual summary, North Carolina 1996 , v. 101, no. 13, 25 p.

1998, Climatological data annual summary, North Carolina 1997, v. 102, no. 13, 25 p.

North Carolina Department of Environment, Health, and Natural Resources, 1992, North Carolina lake assessment report: Raleigh, N.C., Division of Environmental Management, Water Quality Section, Report No. 92-02, 353 p.

- 1995, Catawba River basinwide water quality management plan: Raleigh, N.C., Division of Environmental Management, Water Quality Section, 138 p. + app.

1996, McDowell Creek basin project, May 13, 1993-October 13, 1994: Raleigh, N.C., Water Quality Section, Environmental Sciences Branch, 35 p. + app. -1997, Administrative code sections 15A NCAC 2B.0100 - Procedures for assignment of water quality standards; and 15A NCAC 2B.0200-Classifications and water quality standards applicable to surface waters and wetlands of North Carolina: Raleigh, N.C., Division of Water Quality, 39 p.

North Carolina Department of Environment and Natural Resources, 1998a, Basinwide assessment report, Catawba River Basin: Raleigh, N.C., Division of Water Quality, Environmental Sciences Branch, 236 p. 1998b, North Carolina's 1998 303(d) list: Raleigh, N.C., Division of Water Quality, 70 p.

1999a, Catawba River basinwide water quality plan: Raleigh, N.C., Division of Water Quality, 170 p. + app. 
$1999 b$, Water quality progress in North Carolina, 1996-1997 305(b) report: Raleigh, N.C., Division of Water Quality, 21 p.

2000, Division of Water Quality, Modeling/TMDL Unit, North Carolina's 2000 303(d) list, final draft: accessed May 31, 2000, at URL http://h2o.enr.state.nc.us/mtu/download.html.

Radtke, D.B., 1986, Limnology of West Point Reservoir, Georgia and Alabama, in Subitzky, Seymour, ed., Selected papers in the hydrologic sciences 1986: U.S. Geological Survey Water-Supply Paper 2290, p. $1-16$.

Robinson, J.B., Hazell, W.F., and Garrett, R.G., 1996, Precipitation, streamflow, and water-quality data from selected sites in the City of Charlotte and Mecklenburg County, North Carolina, 1993-95: U.S. Geological Survey Open-File Report 96-150, 136 p.

1998, Precipitation, streamflow, and water-quality data from selected sites in the City of Charlotte and Mecklenburg County, North Carolina, 1995-97: U.S. Geological Survey Open-File Report 98-67, $220 \mathrm{p}$.
Robinson, J.B., Hazell, W.F., and Young, W.S., 1998, Effects of August 1995 and July 1997 storms in the City of Charlotte and Mecklenburg County, North Carolina: U.S. Geological Survey Fact Sheet FS-036-98, 6 p.

Sarver, K.M., Hazell, W.F., and Robinson, J.B., 1999, Precipitation, atmospheric deposition, streamflow, and water-quality data from selected sites in the City of Charlotte and Mecklenburg County, North Carolina, 1997-98: U.S. Geological Survey Open-File Report 99-273, p. 144

Sarver, K.M., and Steiner, B.C., 1998, Hydrologic and water-quality data from Mountain Island Lake, North Carolina, 1994-97: U.S. Geological Survey Open-File Report 98-549, 165 p.

U.S. Environmental Protection Agency, 1990, National pollutant regulations for storm water discharges: U.S. Federal Register, v. 55, no. 222, p. 47990-48091.

Wetzel, 1983, Limnology (2d ed.): San Francisco, Saunders College Publishing, 767 p.

Weiss, C.M., and Kuenzler, E.J., 1976, The trophic state of North Carolina lakes: Raleigh, N.C., Water Resources Research Institute of The University of North Carolina, Report No. 119, 224 p.

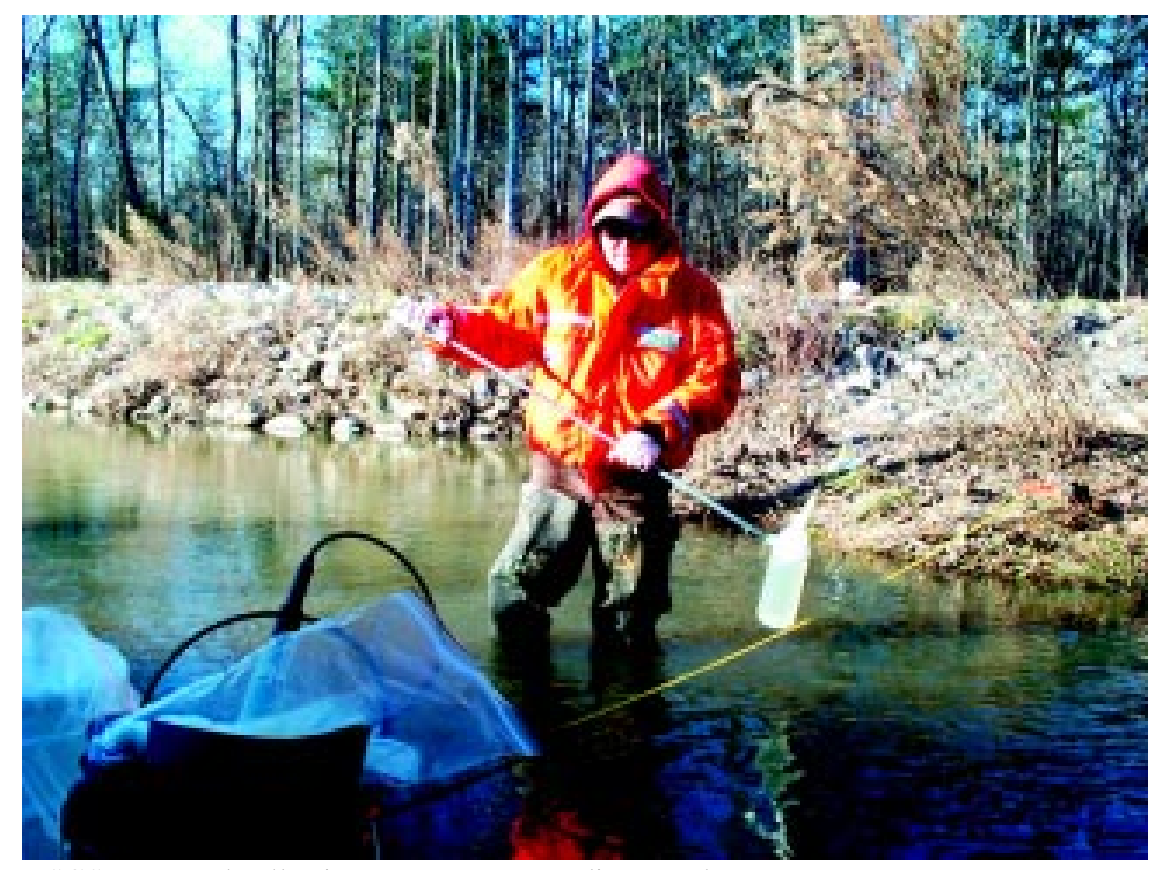

USGS personnel collecting stream water-quality samples (photograph by D.A. Walters, USGS) 